Florida International University

FIU Digital Commons

FIU Electronic Theses and Dissertations

University Graduate School

$11-7-2016$

\title{
Effects of Catastrophic Seagrass Loss and Predation Risk on the Ecological Structure and Resilience of a Model Seagrass Ecosystem
}

Robert J. Nowicki

Department of Biological Sciences, Florida International University, robertjamesnowicki@gmail.com

DOI: $10.25148 /$ etd.FIDC001228

Follow this and additional works at: https:// digitalcommons.fiu.edu/etd

Part of the Behavior and Ethology Commons, Marine Biology Commons, and the Other Ecology and Evolutionary Biology Commons

\section{Recommended Citation}

Nowicki, Robert J., "Effects of Catastrophic Seagrass Loss and Predation Risk on the Ecological Structure and Resilience of a Model Seagrass Ecosystem" (2016). FIU Electronic Theses and Dissertations. 2994.

https://digitalcommons.fiu.edu/etd/2994 


\title{
FLORIDA INTERNATIONAL UNIVERSITY
}

Miami, Florida

\section{EFFECTS OF CATASTROPHIC SEAGRASS LOSS AND PREDATION RISK ON THE ECOLOGICAL STRUCTURE AND RESILIENCE OF A MODEL SEAGRASS ECOSYSTEM}

\author{
A dissertation submitted in partial fulfillment of \\ the requirements for the degree of \\ DOCTOR OF PHILOSOPHY \\ in \\ BIOLOGY \\ by \\ Robert James Nowicki
}

2016 
To: Dean Michael R. Heithaus

College of Arts, Science and Education

This dissertation, written by Robert James Nowicki, and entitled Effects of Catastrophic Seagrass Loss and Predation Risk on the Ecological Structure and Resilience of a Model Seagrass Ecosystem, having been approved in respect to style and intellectual content, is referred to you for judgment.

We have read this dissertation and recommend that it be approved.

William T. Anderson

Deron E. Burkepile

James T. Fourqurean

Joel C. Trexler

Michael R. Heithaus, Major Professor

Date of Defense: November 7, 2016

The dissertation of Robert James Nowicki is approved.

Dean Michael R. Heithaus

College of Arts, Sciences and Education

Andrés G. Gil

Vice President for Research and Economic Development and Dean of the University Graduate School

Florida International University, 2016 
(C) Copyright 2016 by Robert James Nowicki

All rights reserved. 


\section{DEDICATION}

In loving memory of Lorraine Nowicki. 


\section{ACKNOWLEDGMENTS}

It takes a village to write a dissertation, and I have many people to thank. First thanks go to my graduate committee, mentioned above, for their patience and constant guidance throughout the PhD process. Most importantly, thanks to Mike Heithaus, whose guidance, encouragement, baseline sampling, and dislike of waffle words allowed me to grow from a timid postgraduate into a fledgling scientist. I am still awed by your productivity and constant good humor, and thanks to you I have adopted a can-do attitude in my research and my professional life. Thank you for everything.

As for the lab, thanks in particular to Jordy Thomson for showing me the ropes of Shark Bay, including how to run a boat, break a boat, fix a boat, and call for assistance when you can't fix a boat- remember, every crisis is an opportunity. Also thanks for introducing me to Barret's Privateers, cleanskins, and most importantly, Spongebob. Kirk Gastrich deserves many thanks for his constant guidance and advice on all things Shark Bay, for tireless efforts to get the work done, good conversations at the captain's table, and for having an empty bag of chips when we needed it most. Derek Burkholder was also instrumental in helping complete this dissertation, particularly in the care and troubleshooting of our research fleet, of which he is the ultimate authority. I am also in his debt for the gargantuan baseline dataset which only a person of his resolve could build and which made chapter III possible. Thanks to Cindy Bessey (and Brett) for rescuing us from the middle of the outback, acting as a sounding board for ideas, and being the boots on the ground when I was 13,000 miles away. Thanks also to Phil, Adam, Jeremy, Diana, Beth, Camila, Jimmy, and the rest of the Heithaus lab, who made contributions great and small to my development as a grad student and scientist. 
My work in Shark Bay was made possible by the tireless efforts of an army of volunteers, specifically Robin Sarabia, Aaron Macy, Jack Olson, Amy Morgan, Nikita Norton, Jeff Johnson, Matt Jew, Tessa Code, Clark Morgan, Hayley Neutzel, Minna Keynes, and Ellen Last. I'll never forget Aaron being trapped in his caravan by an echidna, Jack's solemn mullet burial, Robin's face after buying $20 \mathrm{~kg}$ of tasty cheese, Amy's tiny red hat, Niki's face after receiving a shot of hot water down a cold wetsuit, Jeff's immigration issue, Matt falling out or off of pretty much everything, Tessa's constant fight with the life ring, the Clark Morgan Book of Wisdom, Hayley's Newt Noises, Minna refusing to say you're welcome, and Ellen apologizing for saying sorry too much. While it is hard for me to measure the true depth of my thanks, I do know it's deeper than 25 feet. Remember, little things become big things.

This work would not have been possible without the generosity and support of the community of Shark Bay. Thanks first to Marty and the Monkey Mia Dolphin Resort for providing accommodation and logistical support for the project. Amber provided critical project assistance in the way only reduced price meat pies can. Grant (Roundy) Brown and son Michael deserve many thanks for their constant help with mechanical know-how and willingness to stop for a minute when the cowl's off and the engine won't start. I will remember Raf, Lu, Sparks, Ave, Adam, Jenn, and the rest of the Monkey Mia crew for their help, great jam sessions, and bonfire chats. Thanks are also due to Harvey, Katie, Toby and all the Shotover crew for the great sails and project assistance. The Shark Bay Pearl Farm provided high resolution temperature data which is used in several chapters, and John at the Fish Factory has generously supplied shark bait for almost 20 years, which made chapter IV possible. Thanks as well to the folks at DPAW, particularly 
Dave for his constant material and logistical support through the project, as well as Lia for her help with data entry and ethical discussions, and Garth for disposing of a bait freezer that failed at the height of summer while I was 13,000 miles away. I still owe you a beer, mate.

I am also in debt to the other Shark Bay researchers; thanks to Megan, Ewa, Eric, Janet and the gang for the barbecues, imitations of captured swallows, and occasional tows when the boat acted up. Thanks to Whitney, Richard, Michael, Sam, Theresea, et al. for the great dinners, board games and more tows when the backup boats acted up.

Thank you Dad and Janet for always being supportive of me, believing in me, loving me, and helping me with things great and small when I'm off gallivanting on the other side of the world. Thanks to Mom as well, who put the fear of God in me when I was young if I brought home from school anything less than my best. I've now internalized that, for better or worse, and that part of you will now always be with me. Also thank you Michael, Heather and Brittany for reminding me of how great being part of a family is. I love you guys.

The last person I have to thank is my fiancé, Robin Sarabia, for letting me drag her out into the outback for six months to help with my project, and for keeping me alive and sane through liberal application of love, patience, humor, and baked goods. You've made these past five years an absolute adventure, and I look forward to future adventures, great and small. Life is better when we're together and that counts for Shark Bay, too. I'll never forget our Emu encounters, the long hikes, or your reaction absolutely every single time you saw a cormorant. I hope that one day you'll forgive me for not using net guns in my project. 
Finally, this project was made possible by multiple funding sources. My stipend was supported by a National Science Foundation Graduate Research Fellowship No. DGE-1038321. Additional funding was from NSF research grant DBI-0620409, NSF RAPID grant OCE1329408, a PADI foundation grant, a dissertation year fellowship (DYF) awarded by FIU, and donations from the public. I thank the editors of the volume Biology of Seagrasses for granting permission for use of chapter II in this dissertation. I apologize for anyone I have omitted- we both know who you are. Thanks again, everyone. 


\section{ABSTRACT OF THE DISSERTATION \\ EFFECTS OF CATASTROPHIC SEAGRASS LOSS AND PREDATION RISK ON THE ECOLOGICAL STRUCTURE AND RESILIENCE OF A MODEL SEAGRASS ECOSYSTEM}

by

\section{Robert James Nowicki}

Florida International University, 2016

Miami, Florida

Professor Michael R. Heithaus, Major Professor

As climate change continues, climactic extremes are predicted to become more frequent and intense, in some cases resulting in dramatic changes to ecosystems. The effects of climate change on ecosystems will be mediated, in part, by biotic interactions in those ecosystems. However, there is still considerable uncertainty about where and how such biotic interactions will be important in the context of ecosystem disturbance and climactic extremes.

Here, I review the role of consumers in seagrass ecosystems and investigate the ecological impacts of an extreme climactic event (marine heat wave) and subsequent widespread seagrass die-off in Shark Bay, Western Australia. Specifically, I compare seagrass cover, shark catch rates, and encounter rates of air breathing fauna in multiple habitat types before and after the seagrass die-off to describe post-disturbance dynamics of the seagrass community, shifts in consumer abundances, and changes in risk-sensitive habitat use patterns by a variety of mesoconsumers at risk of predation from tiger sharks (Galeocerdo cuvier). Finally, I conducted a 16 month field experiment to assess whether 
loss of top predators, and predicted shifts in dugong foraging, could destabilize remaining seagrass.

I found that the previously dominant temperate seagrass Amphibolis antarctica is stable, but not increasing. Conversely, an early-successional tropical seagrass, Halodule uninervis, is expanding. Following the die-off, the densities of several consumer species (cormorants, green turtles, sea snakes, and dugongs) declined, while others (Indo-Pacific bottlenose dolphins, loggerhead sea turtles, tiger sharks) remained stable. Stable tiger shark abundances following the seagrass die-off suggest that the seascape of fear remains intact in this system. However, several consumers (dolphins, cormorants) began to use dangerous but profitable seagrass banks more often following seagrass decline, suggesting a relaxation of anti-predator behavior. Experimental results suggest that a loss of tiger sharks would result in a behaviorally mediated trophic cascade (BMTC) in degraded seagrass beds, further destabilizing them and potentially resulting in a phase shift. My work shows that climactic extremes can have strong but variable impacts on ecosystems mediated in part by species identity, and that maintenance of top predator populations may by important to ecological resilience in the face of climate change. 


\section{TABLE OF CONTENTS}

CHAPTER

PAGE

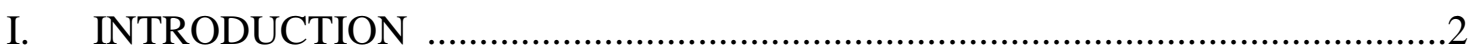

Literature Cited .......................................................................................

II. THE ROLE OF CONSUMERS IN STRUCTURING SEAGRASS COMMUNITIES: DIRECT AND INDIRECT MECHANISMS ...........................11

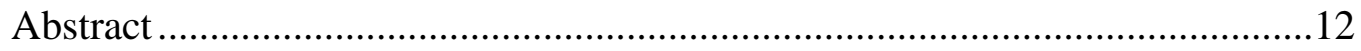

1. The Development of Understanding of Top Down Control on Seagrass

Community Structure.........................................................................................13

2. The Nature of Top Down Control and the Prevalence of Context Dependence....16

3. Effects of Consumers on Seagrass Communities .................................................41

4. Top Down Control and Human Impacts ..............................................................53

5. Conclusions and Future Directions ....................................................................67

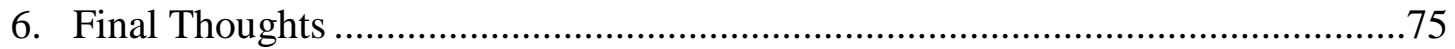

Acknowledgments.......................................................................................

Literature Cited .............................................................................................

III. PREDICTING SEAGRASS RECOVERY TIMES AND THEIR IMPLICATIONS FOLLOWING AND EXTREME EVENT ................................96

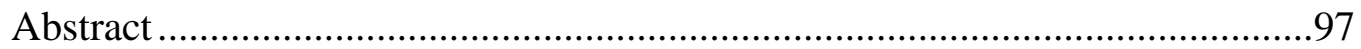

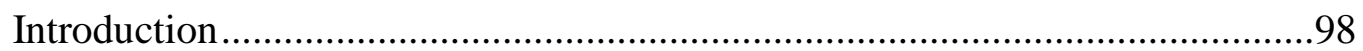

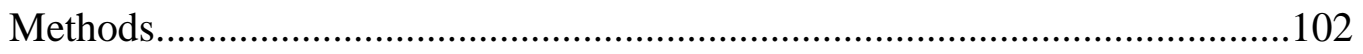

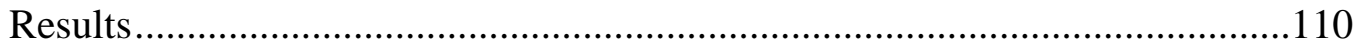

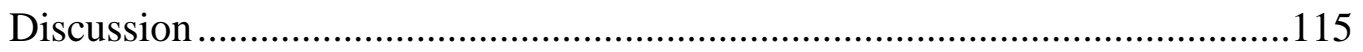

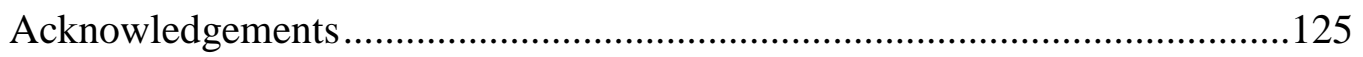

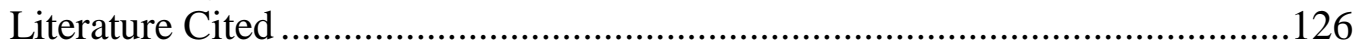

IV. EFFECTS OF MASSIVE SEAGRASS LOSS ON ABUNDANCE AND RISK SENSITIVE HABITAT USE PATTERNS OF AN INTACT MEGAFAUNA

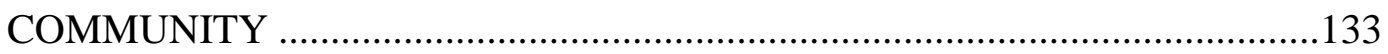

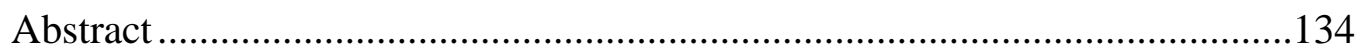

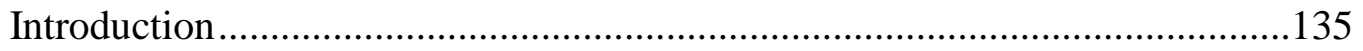

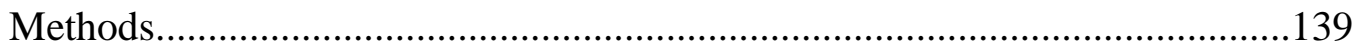

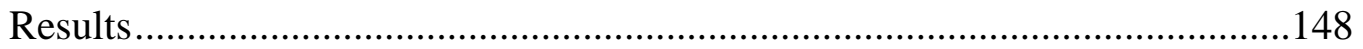

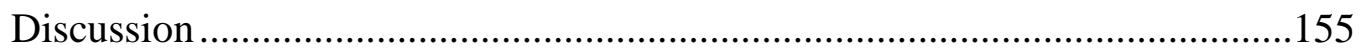

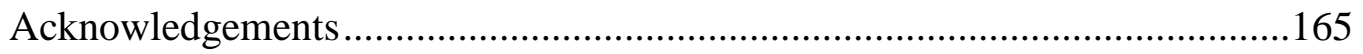

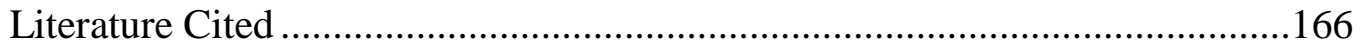

V. EXPERIMENTAL LOSS OF PREDATION RISK GENERATED BY APEX PREDATORS INTENSIFIES ECOSYSTEM IMPACTS OF AN EXTREME

CLIMATE EVENT .............................................................................176

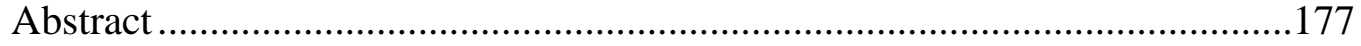




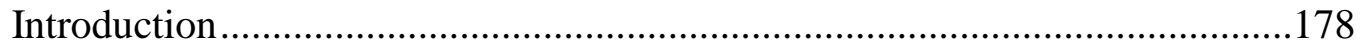

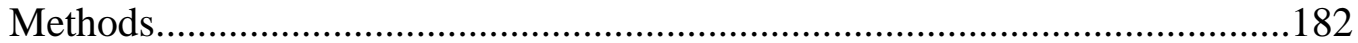

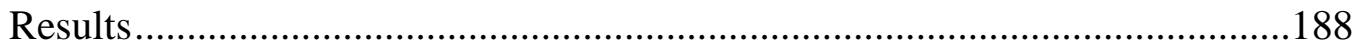

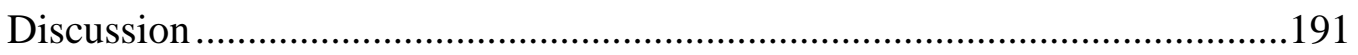

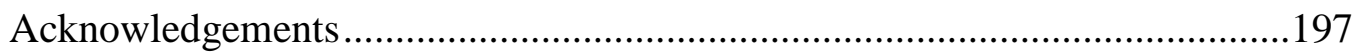

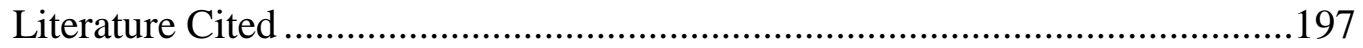

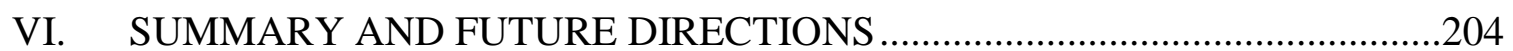

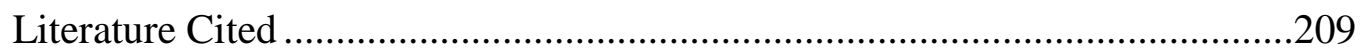

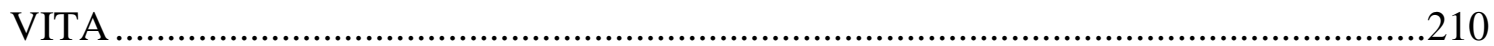




\section{LIST OF TABLES}

TABLE

PAGE

\section{CHAPTER II}

1. Herbivore seagrass preferences around the world. Studies include feeding preference experiments and observational studies. Observational studies (including diet studies and feeding observation studies) were only included if frequency of occurrence of food items was accounted for in the environment. In some cases herbivore preferences correlate positively to nutrient or soluble carbohydrate content of seagrass tissues, or negatively to fiber content; however, these patterns are not universal. Seagrasses with pioneer life histories are italicized; climax seagrasses are listed in bold. Non-seagrass food items are excluded. E:epiphytes removed, T:thin leaf morph, B :broad leaf morph. Hw= Halodule wrightii, $\mathrm{Tt}=$ Thalassia testudinum, $\mathrm{Sf}=$ Syringodium filiforme, $\mathrm{Hu}=$ Halodule uninervis, $\mathrm{Cr}=$ Cymodoce rotundata, $\mathrm{Th}=$ Thalassia hemprichii, $\mathrm{Hs}=$ Halophila spinulosa, $\mathrm{Ho}=$ Halophila ovalis, $\mathrm{Ca}=$ Cymodoce a angustata, $\mathrm{Aa}=$ Amphibolis antarctica, $\mathrm{Pa}=$ Posidonia australis, $\mathrm{Si}=$ Syringodium isotefolium, $\mathrm{Zc}=$ Zostera muelleri (formerly Z. capricorni), $\mathrm{Cs}=$ Cymodocea serrulata, $\mathrm{Hst}=$ Halophila stipulacea, $\mathrm{Tc}=$ Thalassodendron ciliatum, Ea= Enhalus acaroides.

\section{CHAPTER III}

1. Percent occurrence (i.e., percent of visits where that species were present), mean cover when present (i.e., mean percent cover only including sites where that species was present), and mean cover overall (i.e., mean percent cover including all 42 sites) of seagrass and macroalgae in this study. Values are presented with standard error when applicable. Data include bank and bank edge sites only ( $\mathrm{n}=42$ sites); data from the two visits in 2013 are pooled.

2. Logistic model results on the impact of depth, time period, and their interaction on probability of being able to tell bottom cover on shallow seagrass banks. Transect identity was included as a random effect to account for repeated visits on each transect.

3. Number of spot surveys conducted and number of surveys in which bottom was visible from the surface for deep and shallow habitats before and after the seagrass die-off. 


\section{CHAPTER IV}

1. Belt transect widths and sighting distances for each species radii for each species.

2. Fishing effort and catch rates of all sharks and large sharks (those over $3 \mathrm{~m}$ TL) over the course of the study, broken up by season and time period.

3. General additive mixed models (GAMMs) used in model selection for shark catch rates. Day of year (DOY) was included as a smoother function in all models, with season (cold, warm), time period (pre-die-off, post-die-off), and their interaction included as potential fixed effects. Transect identity (ID) and year (Yr) were random effects. AIC=Akaike's Information Criterion. The optimal model is highlighted in bold.

4. Densities for potential tiger shark prey. Turtle sightings include individuals for which species could not be determined, distributed to species based on species ratio estimates (see methods).

5. GLMM results from density and habitat use models of air-breathing mesoconusmers. Details of model construction can be found in the methods....

\section{CHAPTER V}

1. Models applied to macrophyte data. Time since start (Time), bank identity (Bank), and grazing treatment (Treat) were fixed effects. Plot ID was included as a random effect to account for temporal autocorrelation of the repeated measures.

2. Results of optimal model selection for each macrophyte group. Because the response of interest is change in cover over time, only the interactions of treatment:year and bank:year are included here. Values are only given if that parameter was retained in the optimal model for that macrophyte group. Parameters marked with (*) are in comparison to the control treatment.

3. Initial cover and absolute and relative changes in percent cover of $A$. antarctica and benthic macroalgae. Ctrl= control treatment, $\mathrm{SG}=$ simulated grazing, ISG= Intense simulated grazing, $\mathrm{HI}=$ heavily impacted bank, MI=moderately impacted bank. 


\section{LIST OF FIGURES}

\section{CHAPTER II}

1. Examples of types of grazers found in Australian seagrass ecosystems, their feeding tactics, and the resulting impact on seagrass tissue. Tactics are listed in order of increasing per-capita effect on seagrass. Filter feeders are included for completeness, though their grazing of phytoplankton only affect seagrasses indirectly. Photos (clockwise from top left): Shark Bay Ecosystem Research Project (SBERP), Duffy et al. 2014, Rossini et al. 2014, SBERP, SBERP, SBERP, Wikimedia commons, Wikimedia commons, Preen 1995, Burkholder et al. 2013, Eklof et al. 2008, Davis et al. 1998, Goecker et al. 2005, Rossini et al. 2014, Reynolds et al. 2012, SBERP

2. Known distributions of representative Australian seagrass megagrazers and macrograzers. Ranges of macrograzers, however, may reflect geographically restricted research effort rather than true geographic range separations between macrograzers and megagrazers. Map sources by row, left to right: IUCN, IUCN, Encyclopedia of Life, Aquamaps.org, Marinespecies.org.

3. (a): Change in habitat use of dugongs (open triangles), Indo-Pacific bottlenose dolphins (open squares), and Piedcormorants (closed diamonds) associated with changes in abundance of large sharks in Shark Bay, Western Australia. Open diamonds represent the food supply of cormorants. The dashed line represents expected proportion of habitat use if fauna are ideally distributed in relation to their food supply; values above the line represent over-use of seagrass edge habitats, where the chance of tiger shark encounters is highest. (b): Megagrazer exclosure experiments in seagrass edges, which confirm that risk-sensitive habitat use patterns of megaherbivores translate to increased top-down control of seagrass edge habitats. Reproduced from Heithaus et al. 2009 and Burkholder et al. 2013 ......37

4. Conceptual food webs illustrating the main direct and indirect pathways through which top-down control operates in seagrass ecosystems. An intact seagrass community (A) showing direct effects only; (B) a web dominated by the megagrazer pathway; (C) a web dominated by more diffuse mesopredators and smaller seagrass herbivores; (D) a pathway dominated by facultative herbivores like filter feeders, epiphytivores, and algavores. Colors indicate positive (green) or negative (orange) effects of one group on another with arrows denoting direction of effect. Solid and dashed lines indicate direct and indirect effects respectively; greyed out boxes and lines indicate minor consumers and pathways. 
5. Interaction web highlighting potential connections between large shark removal and lower trophic levels based on current quantitave research. Dark and light arrows indicate direct predation and risk effects, respectively; dotted lines indicate indirect effects. Interactions which have been observed in Australian seagrass ecosystems are shaded blue. Note the effects teleosts and invertebrates on seagrasses, as well as estimates of indirect effects in Australian systems, are lacking. Modified from Ferretti et al. 2010.

6. Sites of herbivore exclosure field experiments in Australian seagrass ecosystems (Total= 10 studies, some of which include multiple experiments). Yellow studies achieved herbivore exclusion through in-situ chemical pesticide deployments; other studies used physical cages. Note a complete lack of exclosure studies in tropical Australian ecosystems. Red studies: Jernakoff and Nielsen 1997, Keuskamp 2004, Ebrahim et al. 2014; orange: Garthwin et al. 2014; yellow: Cook et al. 2011, McSkimming et al. 2015; green: Preen 1995, Masini 2001, Burkholder et al. 2013; teal: Bessey et al. 2016. Ebrahim et al. 2014 performed multiple experiments using both cages and pesticides that varied in level of exclusion, from megaherbivore exclusion only to total herbivore exclusion.

\section{CHAPTER III}

1. Location of study area within Australia (A) and the Eastern gulf of Shark Bay (B). Study area pre die-off (Mar. 2010, C) and post die-off (Oct. 2014, D) with estimates of seagrass loss (based on satellite imagery) for each focal bank. Seagrass sampling sites (circles), seagrass banks (gray outlines), water clarity transects (white lines), Monkey Mia (star), and the temperature monitoring station (diamond) are also visible. Images obtained from Google Earth

2. Long-term data illustrating the intensity of the 2011 heat wave and subsequent seagrass die-off. (a) Monthly (average) temperature data, collected every morning at a site immediately west of the study area. (b) Aerial imagery showing the magnitude of change in seagrass cover over decadal time-scales compared to change after the heat wave. Anecdotal accounts from local fishermen suggest no seagrass die-off of this magnitude has occurred in the study area in living memory (R. Nowicki pers. comm)

3. States of A. antarctica beds before and after seagrass die-off. A. antarctica bed before the heat wave and die-off (a). A formerly dense canopy (b) and rhizome mats, now disintegrating (c), photographed in 2013. Water column (d) and benthos (e, left side) during a phytoplankton bloom observed in 2014. Mixed seagrass community of temperate A. antarctica and tropical Halodule 
uninervis (f, black arrow) that has become increasingly common since 2011. Images: SBERP.

4. Change in mean occurrence, mean cover when present, and total mean cover for the three dominant macrophytes in Shark Bay following the heat wave-

(a) Amphibolis antarctica, (b) Halodule uninervis, and (c) benthic macroalgae. Pre die-off values (left of dotted line) are provided when available for comparison. Data from the two visits in 2013 are pooled for consistency with table 1 . Note different scale of Y axes in different graphs. Error bars $=$ s.e.

5. Logistic regression illustrating significantly reduced water clarity $(p=0.016)$ after the seagrass die-off. Points and regressions intentionally jittered on $\mathrm{Y}$ axis.

\section{CHAPTER IV}

1. Shark Bay, Western Australia. The study area is located immediately north of Monkey Mia (asterisk, a) in the Eastern Gulf. The study area is typified by a series of shallow ( $<4.0 \mathrm{~m}$ ) seagrass banks (light grey) separated by deep (6$12 \mathrm{~m}$ ) sandy channels habitats (dark grey). Locations of transect surveys are indicated by black lines. Shark fishing occurred on the three transects marked with asterisks. Modified from Heithaus (2005).

2. Shark fishing effort during pre-die-off (1998-2010) and post-die-off (20122015) periods broken up by season and time period (A). Pre-die-off effort is displayed in blue; post-die-off effort is displayed in orange. Shaded and unshaded areas refer to cold and warm seasons, respectively. Relationships between fishing effort and sharks per hook hour (in all seasons combined) for large (>3m) sharks (B) and all sharks $(\mathrm{C})$

3. Catch rates of all sharks (A) and sharks $\geq 3 \mathrm{~m}$ TL (B) by day of year and time period. LOESS smoothers ( $\mathrm{span}=0.75$ ) with $95 \%$ confidence intervals (shaded buffers) have been applied to better visualize temporal patterns. The cold season is represented by the shaded vertical bar.

4. Changes in overall density (left column), season and habitat-specific densities (central column), and spatio-temporal shifts in habitat use patterns relative to pre-decline patterns (right column) of five groups of air-breathing megafauna in response to seagrass die-off. Significant differences are accompanied by $p$ values. The cold season is shaded. In the right column, values of one represent identical densities for that habitat/season combination before and after the die-off. Seasonal habitat use patterns are considered to have shifted significantly if confidence intervals for each habitat within a season do not 
overlap. Error bars $=95 \%$ CI; scale bars differ in each plot. Photos: SBERP.

\section{CHAPTER V}

1. Conceptual diagram of the role of trophic cascades and physical feedbacks in determining the stability and structure of A. antarctica beds in Shark Bay. (a) In Shark Bay's normal, undisturbed state, tiger sharks regulate megaherbivores by both consumptive and non-consumptive effects (top red arrow), indirectly facilitating persistence of A. Antarctica (left green arrow). Dense seagrass beds generate positive physical feedbacks by trapping sediment and increasing water clarity; these beds also obscure and likely inhibit expansion of the tropical seagrass undercanopy, inhibiting excavation grazing by dugongs and facilitating bed maintenance. (b) With predator losses but without a disturbance, A. Antarctica beds would putatively maintain their ability to generate positive physical feedbacks and inhibit excavation grazing, resulting in a probable loss of resilience but minimal direct impact on A. Antarctica. In (c), a thermal disturbance causes A. Antarctica beds to die back, exposing preferred tropical seagrasses, promoting excavation by dugongs, and reversing positive physical feedbacks. It is at this point that behavioral and consumptive control by tiger sharks is anticipated to be critical to minimizing risky excavation grazing in the degraded bed matrix of temperate and tropical seagrasses. In (d), the dieoff of A. Antarctica and loss of apex predators combine to promote destructive excavation grazing, which favors a phase shift towards an ecosystem dominated by disturbance tolerant tropical seagrass at the expense of temperate late successional seagrass species like A. Antarctica. Both (c) and (d) were tested in this experiment. Photos: SBERP, Wikimedia creative commons

2. Representative states of the study area's Amphibolis antarctica beds in their pre-decline state (a), approximately 18 months after (b) and 36 months after (c) the 2011 marine heat wave. Notice the tropical early successional seagrass Halodule uninervis (small shoots) growing in between the larger shoots of Amphibolis antarctica in (c). Photos: SBERP.

3. Change in cover of Amphibolis antarctica (a), and Halodule uninervis (b), and benthic macroalgae (c) by grazing treatment. Asterisks indicate significant differences in treatment effects when compared to controls. Points intentionally staggered on the $\mathrm{X}$ axis. Scale of $\mathrm{Y}$-axes differ. Error bars $=$ s.e. 


\section{CHAPTER VI}

1. Conceptual model illustrating response of an ecosystem to a climactic extreme as dependent on both properties of the stressor (e.g., intensity, duration, timing, identity) and properties of the ecosystem (which are largely biotic in nature). In both cases, properties may interact to influence the effects of stressors (interactions not shown). 


\section{PREFACE}

The following chapter has been accepted for publication and has been formatted for that volume.

\section{CHAPTER II}

Nowicki, R., Heithaus, M., Fourqurean, J. In press. The role of consumers in structuring seagrass ecosystems: direct and indirect mechanisms. Biology of Seagrasses, Second edition. Eds Larkum, A., Ralph, P., Kendrick, G. Springer, The Netherlands.

Permission has been granted by the editors of this volume to print chapter II of this dissertation. 
CHAPTER I

INTRODUCTION 
Earth's ecosystems are constantly being exposed to anthropogenic stressors. One of the most widespread and pervasive changes humanity is making to the global biosphere is through climate change (Pachauri 2014). Traditionally, climate change ecology has focused on the role of gradual changes to climate regimes over time. However, there is increasing recognition that acute, extreme climactic events can have rapid and dramatic impacts on ecosystems (Jentsch et al. 2007). Recognition of the importance of extreme events, along with more traditional disturbance ecology, has spurred growing interest in determining what makes ecosystems and populations resilient to climactic extremes (and disturbances generally).

While resilience theory continues to advance, investigations into ecological resilience in situ are logistically difficult, particularly true at large spatial and community scales. In situ studies of resilience are difficult because robust investigations into the effects of extreme events need prior standardized baseline sampling at multiple trophic levels, as well as an appropriate extreme event to impact the system of interest. Yet such investigations, when possible, provide deep insights into the responses of entire communities and ecosystems to climactic extremes, and hold particular value in building upon a predictive framework for the effects of such extremes in ecosystems. Therefore, there is considerable value in leveraging climactic extreme events when they occur to increase our understanding of ecosystem responses to climate change.

The role of biotic interactions in mediating the impacts of climate change is becoming increasingly investigated (e.g., Zarnetske et al. 2012). Included therein are species interactions among consumers and between consumers and primary producers. Yet there is still much we do not understand about how various consumers respond to 
climactic disturbances and how they themselves mediate the effects of climate extremes. Apex predators in particular may be important mediators of climate change impacts. Indeed, recent work has demonstrated that apex predators can alter community and ecosystem responses to climate change through consuming prey (e.g., Wilmers and Gets 2005, Ling et al. 2009). However, predators alter communities not only through direct predation, but also through risk of predation and the interaction of the two (e.g., Schmitz et al. 1997, Lima 1998, Dill et al. 2003, Werner and Peacor 2003). Predator "risk" effects, by impacting large proportions of prey populations and generating behaviorally mediated trophic cascades (Jeffries and Lawton 1984, Heithaus et al. 2008), can even be more powerful than direct predation (e.g., Werner and Peacor 2003, Creel and Christianson 2008). Predation risk may, therefore, be an important component of ecological resilience to climate extremes. Studies of when and how top predators may influence ecological resilience in the face of climate change is particularly important because of extreme declines in their populations on land (e.g., Ripple et al. 2014) and in the oceans (e.g., Ferretti et al. 2010)

Seagrass ecosystems are good candidates for investigations of resilience in the face of climate change for several reasons. Seagrass ecosystems provide a variety of critical ecosystem functions, including primary and secondary productivity, sediment stabilization, wave attenuation, habitat creation, and carbon storage (e.g., Heck et al. 2003, Smit et al. 2005, Barbier et al. 2011, Fourqurean et al. 2012). Despite these functions, seagrass ecosystems are among Earth's most imperiled, with dramatic losses (29\%) since the late 1800 's that continue to accelerate (Waycott et al. 2009). There is thus considerable urgency and value to maximizing resilience in these ecosystems. 
Furthermore, many of the regions in which seagrasses are well studied (including the East coast of the USA, East and West coast of Australia, and the East coast of Japan) are characterized by tropical boundary currents and are predicted to warm several times faster than the global average (Verges et al. 2014, Wu et al. 2012). As such, seagrass ecosystems are at the forefront of climate change and may provide a good platform for climate change research. Additionally, seagrass ecosystems are known for positive feedbacks which can reinforce phase shifts once they occur, making it critical to understand under what conditions these systems will display resilience or phase shifts in response to disturbance. Finally, seagrasses of temperate and tropical origin often have different life histories and fulfill different functional roles in their ecosystems. Specifically, many temperate seagrasses are large and persistent, with late-successional life histories and slow rates of vegetative expansion; conversely, many tropical seagrasses are typified by early-successional life histories and rapid rates of vegetative expansion, but are often smaller and less structurally complex than their temperate counterparts (Larkum et al. 2006). Therefore, seagrass losses or species shifts to more structurally simple, early successional tropical seagrasses may greatly alter the valuable functions that characterize seagrass ecosystems (Hyndes et al. 2016).

The goal of my dissertation is to investigate the impacts of a climactic extreme event and subsequent widespread seagrass die-off on the communities, and the ecosystem resilience of Shark Bay, Western Australia. Furthermore, I seek to ask whether loss of Shark Bay’s local apex predators, tiger sharks (Gaelocerdo cuvier), may generate a behaviorally mediated trophic cascade (BMTC) that would destabilize damaged seagrass beds by increasing grazing pressure on them from dugongs. Shark Bay is a particularly 
valuable system for such a study because it is among the world's largest seagrass ecosystems (Walker et al. 1988), hosts a relatively intact consumer community from herbivorous dugongs (Dugong dugon) to tiger sharks, and has been subject of a broad, long term ecological research effort since 1997 (Heithaus et al. 2012). Furthermore, extensive work on the role of predation risk generated by seasonally abundant tiger sharks has allowed for detailed study of anti-predator behavior by a variety of mesoconsumers, allowing for the unique capability to investigate how massive resource loss influences the dynamics of predator-prey interactions in a large scale field setting.

I begin by reviewing the literature on the role of consumers in seagrass ecosystems (Chapter II) with a particular focus on the Australian continent. Therein I investigate the role that herbivores and predators are known to play in seagrass ecosystems, concluding with current research gaps and predictions of how climate change and top-down control will shape seagrass ecosystems in the future.

The extent and magnitude of the initial seagrass decline has been described previously (Thomson et al. 2014, Fraser et al. 2014). For Chapter III, I therefore undertook standardized sampling of Shark Bay's seagrass community following the decline to investigate the post-disturbance dynamics of the study area, with a particular focus on community shifts and factors likely to impact return time and resilience.

Such extensive loss of Amphibolis antarctica, Shark Bay's historically dominant seagrass (Walker et al. 1988), provided a unique opportunity to investigate the effects of widespread resource loss on a wide variety of megafauna, including dugongs, IndoPacific bottlenose dolphins, Piedcormorants, green and loggerhead sea turtles, sea snakes, and large sharks in Chapter IV. In addition to quantifying shifts in abundance for these 
species I also measured whether these mesoconsumers continue to exhibit risk-sensitive habitat use in response to seasonal variation in abundances of tiger sharks, which provided a unique ability to evaluate theoretical predictions of how resource loss affects anti-predator behavior.

In Chapter V, I present the results of a field experiment designed to determine whether the ecological extinction of tiger sharks from Shark Bay as a result of overfishing, and the resulting shifts in dugong habitat use and foraging behavior, could eliminate a behaviorally mediated trophic cascade (BMTC) leading to a destabilization of the remaining beds of A. antarctica. Specifically, I test whether changes in risk-sensitive foraging behavior by dugongs predicted to occur in the absence of top predators will prevent the recovery of $A$. antarctica beds and instead result in a phase shift to a seagrass ecosystem dominated by tropical seagrasses such as Halodule uninervis. The question of whether apex predators can influence the ecological resilience of a disturbed ecosystem through behavioral control of prey is an important one in the context of climate change since marine predator losses are widespread and can have important ecological impacts (Ferretti et al. 2010, Heithaus et al. 2008). In my final chapter, I synthesize and summarize my findings and place them in the context of predictive ecology. I also emphasize a more general need to increase the predictive capacity of ecology. I build on existing predictive frameworks and make suggestions as to areas where further work is most needed.

Overall this work provides a valuable case study into the ecological effects of a climactic extreme event in a relatively intact marine ecosystem, and uses large scale observational and experimental work to evaluate several theoretical predictions. Therein, 
this work contributes to the construction of a predictive framework for the resilience of ecosystems to climactic extremes.

Literature cited

Barbier, E.B., Hacker, S.D., Kennedy, C., Koch, E.W., Stier, A.C. \& Silliman, B.R. (2011). The value of estuarine and coastal ecosystem services. Ecological monographs, 81, 169-193.

Creel, S. \& Christianson, D. (2008). Relationships between direct predation and risk effects. Trends in Ecology \& Evolution, 23, 194-201.

Dill, L.M., Heithaus, M.R. \& Walters, C.J. (2003). Behaviorally mediated indirect interactions in marine communities and their conservation implications. Ecology, 84, 1151-1157.

Ferretti, F., Worm, B., Britten, G.L., Heithaus, M.R. \& Lotze, H.K. (2010). Patterns and ecosystem consequences of shark declines in the ocean. Ecology Letters, 13, 1055-1071.

Fourqurean, J.W., Duarte, C.M., Kennedy, H., Marbà, N., Holmer, M., Mateo, M.A., et al. (2012). Seagrass ecosystems as a globally significant carbon stock. Nature Geoscience, 5, 505-509.

Fraser, M.W., Kendrick, G.A., Statton, J., Hovey, R.K., Zavala-Perez, A. \& Walker, D.I. (2014). Extreme climate events lower resilience of foundation seagrass at edge of biogeographical range. Journal of Ecology, 102, 1528-1536.

Heck, K.L., Hays, G. \& Orth, R.J. (2003). Critical evaluation of the nursery role hypothesis for seagrass meadows. Marine Ecology Progress Series, 253, 123136.

Heithaus, M.R., Frid, A., Wirsing, A.J. \& Worm, B. (2008). Predicting ecological consequences of marine top predator declines. Trends in Ecology \& Evolution, 23, 202-210.

Heithaus, M.R., Wirsing, A.J. \& Dill, L.M. (2012). The ecological importance of intact top-predator populations: a synthesis of 15 years of research in a seagrass ecosystem. Marine and Freshwater Research, 63, 1039-1050.

Hyndes, G.A., Heck, K.L., Vergés, A., Harvey, E.S., Kendrick, G.A., Lavery, P.S., McMahon, K., Orth, R.J., Pearce, A., Vanderklift, M., Wernberg, T., Whiting, S., Wilson, S. (2016). Accelerating Tropicalization and the Transformation of Temperate Seagrass Meadows. BioScience, 66, 938-948. 
Jeffries, M.J. \& Lawton, J.H. (1984). Enemy free space and the structure of ecological communities. Biological Journal of the Linnean Society, 23, 269-286.

Jentsch, A., Kreyling, J. \& Beierkuhnlein, C. (2007). A new generation of climate-change experiments: events, not trends. Frontiers in Ecology and the Environment, 5, $365-374$.

Larkum A, Orth R, Duarte C (Eds) (2006) Seagrasses: Biology, Ecology, and Conservation. Springer Netherlands, Dordrecht

Lima, S.L. (1998). Nonlethal Effects in the Ecology of Predator-Prey Interactions. BioScience, 48, 25-34.

Ling, S.D., Johnson, C.R., Frusher, S.D. \& Ridgway, K.R. (2009). Overfishing reduces resilience of kelp beds to climate-driven catastrophic phase shift. Proceedings of the National Academy of Sciences, 106, 22341-22345.

Pachauri, R.K., Allen, M.R., Barros, V.R., Broome, J., Cramer, W., Christ, R., et al. (2014). Climate Change 2014: Synthesis Report. Contribution of Working Groups I, II and III to the Fifth Assessment Report of the Intergovernmental Panel on Climate Change.

Ripple, W.J., Estes, J.A., Beschta, R.L., Wilmers, C.C., Ritchie, E.G., Hebblewhite, M., et al. (2014). Status and ecological effects of the world's largest carnivores. Science, 343, 1241484.

Schmitz, O.J., Beckerman, A.P. \& O'Brien, K.M. (1997). Behaviorally mediated trophic cascades: effects of predation risk on food web interactions. Ecology, 78, 13881399.

Smit, A.J., Brearley, A., Hyndes, G.A., Lavery, P.S. \& Walker, D.I. (2005). Carbon and nitrogen stable isotope analysis of an Amphibolis griffithii seagrass bed. Estuarine, Coastal and Shelf Science, 65, 545-556.

Thomson, J.A., Burkholder, D.A., Heithaus, M.R., Fourqurean, J.W., Fraser, M.W., Statton, J., et al. (2015). Extreme temperatures, foundation species, and abrupt ecosystem change: an example from an iconic seagrass ecosystem. Global change biology, 21, 1463-1474.

Vergés, A., Steinberg, P.D., Hay, M.E., Poore, A.G., Campbell, A.H., Ballesteros, E., Heck, K.L., Booth, D.J., Coleman, M.A., Feary, D.A., Figueira, W., Langlois, T., Marzinelli, E.M., Mizerek, T., Mumby, P.J., Nakamura, Y., Roughan, M., van Sebille, E., Gupta, A.S., Smale, D.A., Tomas, F., Wernberg, T., Wilson, S.K. (2014). The tropicalization of temperate marine ecosystems: climate-mediated 
changes in herbivory and community phase shifts. In: Proc. R. Soc. B. The Royal Society, 281, 20140846.

Walker, D.I., Kendrick, G.A. \& McComb, A.J. (1988). The distribution of seagrass species in Shark Bay, Western Australia, with notes on their ecology. Aquatic Botany, 30, 305-317.

Waycott, M., Duarte, C.M., Carruthers, T.J.B., Orth, R.J., Dennison, W.C., Olyarnik, S., Calladine, A., Fourqurean, J.W., Heck, K.L., Hughes, R.A., Kendrick, G.A., Kenworthy, W.J., Short, F.T., Williams, S.L. (2009). Accelerating loss of seagrasses across the globe threatens coastal ecosystems. Proceeding of the National Academy of Sciences, 106, 12377-12381.

Werner, E.E. \& Peacor, S.D. (2003). A review of trait-mediated indirect interactions in ecological communities. Ecology, 84, 1083-1100.

Wilmers, C.C. \& Getz, W.M. (2005). Gray wolves as climate change buffers in Yellowstone. PLoS Biol, 3, e92.

Wu, L., Cai, W., Zhang, L., Nakamura, H., Timmermann, A., Joyce, T., McPhaden, M.J.m Alexander, M., Qiu, B., Visbeck, M., Chang, P., Giese, B. (2012). Enhanced warming over the global subtropical western boundary currents. Nature Climate Change, 2, 161-166.

Zarnetske, P.L., Skelly, D.K. \& Urban, M.C. (2012). Biotic multipliers of climate change. Science, 336, 1516-1518. 
CHAPTER II

THE ROLE OF CONSUMERS IN STRUCTURING SEAGRASS COMMUNITIES:

DIRECT AND INDIRECT MECHANISMS 


\begin{abstract}
Seagrass ecosystems were traditionally assumed to be structured by competition as well as by "bottom up forces" such as resource availability and disturbance. However, a wealth of new evidence demonstrates that exertion of "top down control" by animals may be widespread. The strength and direction of top down control is context dependent, however, and varies with properties of organisms, the community, and the physical environment. Consumers can facilitate, consume, or destroy primary producers, aid or inhibit seagrass reproduction, or alter bottom up processes with implications for the properties and persistence of seagrass ecosystems. Studies in Australian ecosystems have been critical in helping to elucidate the role of consumers in seagrass ecosystems. Specifically, work investigating the roles of megaherbivores and apex predators and the pioneering of novel experimental approaches which allow for cage-free manipulations of mesograzers have substantially furthered our understanding of top-down control. At the broadest scale, megagrazers are likely to dominate grazing pathways in Australian tropical and subtropical seagrass ecosystems, while macrograzers and mesograzers do so in temperate seagrass ecosystems. However, while we have learned much about mechanisms through which top-down control can operate and its effects on seagrass ecosystems, predicting which grazing pathways dominate at smaller spatial scales, and net herbivore effects on seagrasses in specific ecosystems remains challenging due to context dependence and the highly complex nature of species interactions. Anthropogenic impacts further complicate these relationships. Australian seagrass habitats possess unusual properties, including relatively intact populations of megafauna,
\end{abstract}


remote and pristine locations, and distinctive oceanographic features which allow these habitats to provide unique insights of top down control in seagrass ecosystems.

\section{The Development of Understanding of Top Down Control on Seagrass Community Structure}

One of the central goals of ecology is to understand the forces that structure ecosystems. In pursuing this goal, ecologists have traditionally focused on the roles of physical factors such as light, water and nutrient availability in controlling ecosystems from the "bottom up." This focus on bottom up control was due in part to the ease with which physical variables can be manipulated in controlled experiments. Though ecologists and naturalists had written about the importance of consumers and "top down" forces in ecosystems throughout the field's history (e.g., Elton 1927), it wasn't until a seminal paper published by Hairston, Smith, and Slobodkin (1960) that the role of consumers was brought into the ecological limelight. This paper presented what is known as the "green world hypothesis," and asked a simple question: if herbivores are only limited by resources, then why do plants in terrestrial ecosystems persist? One reason, the authors posited, is that herbivores are not limited from the "bottom up" by plant resources, but from the "top down" by predators- and that this top down control is what allows primary producers to survive. This hypothesis, though remaining far from universally accepted (see Ehrlich and Raven 1964, Murdoch 1966, Strong 1992, Polis and Strong 1996, Polis 1999 for critiques and alternate hypotheses), set the stage for subsequent studies investigating the role of top down control in ecosystems. 
Until relatively recently, the importance of top-down control in seagrass ecosystems went largely unrecognized. Indeed, seagrass ecology focused on factors in the physical environment that limited seagrass establishment, growth and distributionherbivory and predation were considered relatively unimportant (Kirkman and Reid 1979, Klumpp et al 1989). This view began to incrementally change, particularly in the 1980s, when several reviews suggested that the persistence of seagrass ecosystems may be due to herbivore control of algal competitors, which are generally faster growing than seagrasses (Orth and Montfrans 1984, Montfrans et al. 1984). The suggestion that top down control may be important in limiting algal overtake of seagrass ecosystems has since been widely recognized (e.g., Hughes et al. 2004, Heck and Valentine 2007, Verhoeven et al. 2012).

Though there was increasing realization that top down control could play important roles in seagrass-algae dynamics, the paradigm remained that seagrasses themselves were only rarely consumed by herbivores and that most seagrass production was probably channeled into the detrital cycle (Kirkman and Reid 1979, Thayer et al. 1984, Klumpp et al 1989). This idea persisted despite the knowledge that sirenians, sea turtles, teleosts and sea urchins that live in seagrass meadows are herbivorous (Klumpp et al 1989, Lanyon et al. 1989) and that the effects of grazers on the structure of seagrass beds can, in some cases, be readily apparent (Randall 1965). Contributions from historical ecology and contemporary experiments performed over several decades, began to challenge this paradigm.

Taking a historical perspective, some ecologists observed that the seagrass ecosystems of today are rarely intact or natural ecosystems. Modern seagrass 
ecosystems, they argued, are largely released from top-down control because the marine megaherbivores that roamed such ecosystems centuries or millennia prior had been hunted to functional extinction (Dayton et al. 1995, Domning 2001, Jackson 2001, Heck and Valentine 2007). In a way, this argument echoed that of Hairston et al. (1960)seagrass ecosystems were green because predators (in this case, humans) were highly effective at exerting top down control on seagrass herbivores such as sea turtles, sirenians, sharks. Thus, ecologist's observations of low rates of herbivory in seagrass ecosystems could in fact be the result of human activity that set an unnatural "baseline" that betrays the truth of the evolutionary and ecological importance of herbivory in these systems.

Other ecologists argued that seagrass herbivory was not only still occurring, but that it could still have strong effects in seagrass ecosystems today. Largely led by the work of ecologists working in the Gulf of Mexico and Northwestern Atlantic, a suite of observations, experiments, reviews, and meta-analyses has built compelling evidence that significant seagrass consumption (and top-down control) continues in contemporary seagrass ecosystems (Valentine and Heck 1991, Heck and Valentine 1995, Cebrian and Duarte 1998, Rose et al. 1999, Valentine and Heck 1999, Williams and Heck 2001, Kirsch et al. 2002, Hughes et al. 2004, Nakaoka 2005, Valentine and Duffy 2006, Heck and Valentine 2007). Even in the relative absence of marine megafauna, multiple experiments showed how consumer control can still shape seagrass ecosystems at scales from individual plants to the entire community. Partially as a consequence of these and other experiments, the idea that predators play critical roles in controlling herbivory in seagrass ecosystems also gained support (Heck et al. 2000, Williams and Heck 2001, 
Valentine and Duffy 2006)- something first observed to be important to the formation of the grazing halos described decades before (Randall 1965). Evidence for top down control in seagrass ecosystems (including trophic cascades) continues to accumulate today (Hughes et al. 2004, Burkepile and Hay 2006, Heck and Valentine 2006, Heithaus et al. 2012, Burkholder et al. 2013, Duffy et al. 2013).

By the late 1980s, when the first edition of this book was published, it had begun to become apparent that seagrass herbivory was more important than previously recognized, though most of the focus remained on large bodied consumers like dugongs and green turtles (Lanyon et al. 1989). Now, there is compelling evidence that consumers of varied body size and feeding guild can exert top down control through a variety of mechanism and trophic pathways, sometimes with strong and counterintuitive effects on their ecosystems. The challenge now is not in determining if top-down control exists in seagrass ecosystems, but when it is important relative to other forces, by what mechanisms top-down control most commonly operates, and by what pathways it is most likely to dominate. While work to identify mechanisms of top down control has been fruitful, predicting when (and through what avenues) top down control dominates in seagrass ecosystems has proven difficult and remains a key challenge in seagrass ecology.

\section{The Nature of Top Down Control and the Prevalence of Context Dependence}

In order to understand when, where, through which pathways and mechanisms, and how strong top-down influences are, an understanding of the roles of consumers, producers, and their relationships to each other and their environment is necessary. In the 
most basic sense, the strength and nature of top down control in seagrass ecosystems is a function of the properties of herbivores, predators, and the seagrass, community structure, and features of the physical environment. Seagrasses, and the other primary producers they interact with, have inherently different life histories, chemical compositions, and tolerances to herbivory and environmental conditions. These properties interact with properties of herbivores- their densities, identity, consumption rates, or feeding preferences. Predators in turn influence herbivores or the predators of herbivoresaltering their density, traits and behavior- which can generate cascading effects to seagrasses. The strength of these interactions is often linked to food web complexity. Consumers also interact with seagrass directly through nutrient transport and concentration, physical restructuring of habitat, and changes to bottom-up processes. Finally, these interactions occur in the context of the physical environment and are further complicated by anthropogenic impacts such as nutrient pollution, predator removal, and climate change. Below I consider how each of these taxa, guilds, or factors influences the strength and nature of top-down control, providing examples from experiments or observational work to support these considerations.

\subsection{The Role of Seagrass in Mediating the Strength of Top-Down Processes}

Plants are not simply the recipients of consumer effects; they also play an important role in mediating the ultimate effects consumers have on the primary producer community. As one ecologist wrote, "Plants are not passive agents, waiting to be decimated by herbivores" (Polis 1999). Primary producers, including seagrasses, microalgae, and macroalgae, can alter the strength of top down control through their 
susceptibility and response to herbivory, which may, in turn affect herbivore behavior. Seagrasses exposed to herbivory may decline or die-off, exhibit tolerance through compensatory or super-compensatory growth, or display resistance by altering their physiology or chemistry through methods such as nutrient or carbohydrate re-routing or by producing secondary metabolites (Cebrian et al. 1998, Ricklefs and Miller 1999, Vergés et al. 2008, Burnell et al. 2013a, Steele and Valentine 2015). The tolerance of primary producers to different kinds of herbivory differs by species- though it can also be induced in response to herbivory (e.g., Burnell et al. 2013a, Sanmarti et al. 2014)- and this differential tolerance can have implications for seagrass community composition. For example, in mixed species seagrass meadows in Lady Bay, South Australia, overgrazing of seagrasses by sea urchins disproportionately impact Amphibolis antarctica compared to Posidonia spp., because the leaf cluster meristems of A. antarctica are exposed at the surface and therefore are more vulnerable to grazing while the meristems of Posidonia species are protected beneath the sediment surface (Burnell et al. 2013a). In this sense, differences in morphology mediate the strength of consumer control of these mixed-species beds.

In general, the life history characteristics of pioneer seagrasses like those in the genera Halophila, Halodule, Syringodium, allow them to grow and expand quickly, giving them generally high grazing tolerance on the level of the meadow, even if their standing biomass is often heavily reduced by regular grazing (e.g., Preen 1995, Masini et al. 2001). Climax seagrasses like those in the Australian genera Amphibolis, Posidonia, and Zostera grow and expand more slowly, but are also less ephemeral, forming dense, thick beds with generally higher stocks of standing biomass. This "climax" life history, 
however, results in slower responses to large grazing events that can be generated by herbivores like dugongs and urchins (see Preen 1995, Eklöf et al. 2008 for examples). Some climax species, like Amphibolis antarctica, do not even generate seeds (Hemminga and Duarte 2000), instead requiring live plants to recolonize heavily grazed areas. As we will see, life history characteristics also relate to herbivore feeding preferences.

While primary producers alter how top-down control operates in seagrass ecosystems via their responses to herbivory, they also do so through their properties as a resource. Because seagrasses can act as a different kind of resource (i.e., food, shelter) for different consumers, seagrass properties can influence not only herbivore feeding rates and food preferences, but also habitat use preferences. These preferences can have measurable impacts on seagrass community structure (Preen 1995, Armitage and Fourqurean 2006). Consumer feeding patterns are influenced by variation in primary producer chemical properties (i.e., palatability or food quality), structural properties (i.e., complexity, which provides refuge for predators or herbivores), or through community composition (associations with other producers that may illicit such preferences in herbivores).

From an herbivory perspective, seagrass chemical composition describes the concentration of not only nutrients and soluble carbohydrates which often attract grazing, but also fiber and secondary metabolites, which can deter it. Generalizing the relationship between the seagrass chemical composition and herbivore feeding preference or feeding rate remains surprisingly difficult. For example, some studies find a positive relationship between nutrient content and herbivore feeding preference or consumption rates (ex. McGlathery et al. 1995, Brand-Gardner et al. 1999, Goecker et al. 2005, Prado 
et al. 2010, Sheppard et al. 2010, Burkholder et al. 2012), while others do not (Cebrian and Duarte 1998, Mariani and Alcoverro 1999, Valentine and Heck 2001, Kirsch et al. 2002, White et al. 2011). This is partially due to the fact that nutrient concentrations as measured in assays may not accurately reflect the actual nutritional content a seagrass presents to herbivores since many nutrients can be bound to indigestible plant tissue that is never assimilated (Cebrian and Duarte 1998). However, some of this complexity is derived from simultaneous variation in defensive compounds which reduce palatability. For example, feeding trials and manipulations using the bucktooth parrotfish Sparisoma radians indicate this herbivore prefers macrophytes in inverse relation to their terpene content, even when other factors such as species or biteability are accounted for (Targett et al. 1986). Similarly, in Watamu National Marine Park, Kenya, feeding preferences of the teleost herbivore Calotomus carolinus are inversely correlated to the carbon fiber content of primary producer species (Mariani and Alcoverro 1999, Table 1). The relationship between nutrient ratios, plant defenses, and herbivore feeding preference is further obscured by the fact that plant characteristics can fluctuate across space, time, species, and individual (e.g., Fourqurean et al 2005, Hays 2005, Tomas et al. 2011, Steele and Valentine 2015). This complicates drawing patterns because multiple chemical variables can change concurrently, making attribution of herbivory to a single compound or group of compounds difficult. For example, newer seagrass leaves generally have higher nutrient concentrations and fewer structural compounds than older leaves, but may also have higher concentrations of phenolic compounds (Hemminga and Duarte et al. 2000, Agostini et al. 1998, Vergés et al. 2011). Older leaves also tend to have higher epiphyte loads, making them more attractive to grazers targeting epiphytes (Alcoverro et 
al. 1997, Wressing and Booth 2007, Vergés et al. 2011), and seagrass leaves have higher $\mathrm{N}$ and $\mathrm{P}$ content in winter compared to summer in seasonal environments (Fourqurean et al 1997, 2005, 2007). Finally, different herbivores place varying levels of importance on each of these seagrass qualities (Prado and Heck 2011) meaning that understanding herbivore feeding preference requires not only comprehensive knowledge of seagrass chemical properties, but also insight into which of those properties local herbivores consider most. Despite the complex relationship between chemical properties and herbivory, investigations into a generalizable pattern are important as these chemical properties can significantly influence herbivory rates (e.g., Steele and Valentine 2015).

Though the multitude of factors driving herbivore feeding preferences in seagrass meadows has made generalizing preferences very difficult, one general pattern has emerged. Feeding assays, gut content analysis, and herbivore exclosure experiments indicate that faster growing seagrass species - many of which are of tropical origin - are generally consumed more readily than slower growing climax species (Cebrian and Duarte 1998, Mariani and Alcoverro 1999, Armitage and Fourqurean 2006, Prado and Heck 2011, Burkholder et al. 2012, Table 1). This pattern holds in Australian seagrass ecosystems, where fast-growing seagrasses are more readily consumed than temperate species; the latter are more likely to be targeted for their epiphytes rather than their tissue (Preen 1995, Burkholder et al. 2012). Pioneer-type seagrassess tend to be less structurally complex and higher quality food than climax seagrasses, often due to higher nutritional content, lower mechanical resistance to grazing, or both (i.e., de los Santos et al. 2012.). 
Table 1. Herbivore seagrass preferences around the world. Studies include feeding preference experiments and observational studies. Observational studies (including diet studies and feeding observation studies) were only included if frequency of occurrence of food items was accounted for in the environment. In some cases herbivore preferences correlate positively to nutrient or soluble carbohydrate content of seagrass tissues, or negatively to fiber content; however, these patterns are not universal. Seagrasses with pioneer life histories are italicized; climax seagrasses are listed in bold. Non-seagrass food items are excluded. E:epiphytes removed, T:thin leaf morph, B :broad leaf morph. $\mathrm{Hw}=$ Halodule wrightii, $\mathrm{Tt}=$ Thalassia testudinum, $\mathrm{Sf}=$ Syringodium filiforme, $\mathrm{Hu}=$ Halodule uninervis, $\mathrm{Cr}=$ Cymodoce a rotundata, $\mathrm{Th}=$ Thalassia hemprichii, $\mathrm{Hs}=$ Halophila spinulosa, $\mathrm{Ho}=$ Halophila ovalis, $\mathrm{Ca}=$ Cymodoce a angustata, $\mathrm{Aa}=$ Amphibolis antarctica, $\mathrm{Pa}=$ Posidonia australis, $\mathrm{Si}=$ Syringodium isotefolium, $\mathrm{Zc}=$ Zostera muelleri (formerly Z. capricorni), $\mathrm{Cs}=$ Cymodocea serrulata, $\mathrm{Hst}=$ Halophila stipulacea, $\mathrm{Tc}=$ Thalassodendron ciliatum, $\mathrm{Ea}=$ Enhalus acaroides .

\begin{tabular}{|c|c|c|c|}
\hline Consumer & Preferences & Region & Reference \\
\hline Mostly fish & $H w>\mathrm{Tt}$ & South Florida, USA & Armitage and Fourqurean 2006 \\
\hline Three fish species & $S f>H w>T t$ & Caribbean & Prado and Heck 2011 \\
\hline Sea urchins & $H w>S f>T t$ & Caribbean & Prado and Heck 2011 \\
\hline Dugongs & $\mathrm{Hu}>\mathrm{Cr}>\mathrm{Th}$ & Indonesia & De longh et al. 1995 \\
\hline Fish (Scaridae) & $\mathrm{Tt}>H w>\mathrm{Tt}^{\mathrm{E}}>S f$ & Caribbean & Lobel and Ogden 1981 \\
\hline Fish (probable) & $\mathrm{Hs}=\mathrm{Hu}=\mathrm{Ho}>\mathrm{Ca}>\mathrm{Aa}=\mathrm{Pa}$ & Shark Bay, Western Australia & Burkholder et al. 2012 \\
\hline Dugongs & $\mathrm{Ho}>\mathrm{Hu}^{\top}>\mathrm{Hs}>\mathrm{Si}>\mathrm{Hu}^{\mathrm{B}}>\mathrm{Zc}$ & Moreton Bay, Queensland & Preen 1992 \\
\hline Fish (Scaridae) & $\mathrm{Cr}>\mathrm{Si}>\mathrm{Hu}=\mathrm{Hw}>\mathrm{Th}>\mathrm{Cs}=\mathrm{Hs}>\mathrm{Tc}>\mathrm{Ea}$ & $\begin{array}{c}\text { Watamu marine national } \\
\text { park, Kenya }\end{array}$ & Mariani and Alcoverro 1999 \\
\hline Neritid gastropod & $\mathrm{Zc}>\mathrm{Ho}>\mathrm{Cs}$ & Moreton Bay, Queensland & Rosini et al. 2014 \\
\hline Green turtle & $\mathrm{Th}>\mathrm{Cr}$ & Lakshadweep islands, India & Kelkar et al. 2013 \\
\hline
\end{tabular}

Seagrass physical structure can also influence top down control by generating refuge or habitat for herbivores or predators, altering habitat use patterns of fauna and, by extension, where and what they consume. For example, amphipods in beds of Zostera marina in San Francisco Bay, USA, associate with structurally complex inflouresences over leaves, which may be responsible for increased consumption of inflouresences and associated reduced reproductive potential (Reynolds et al. 2012). Seagrass structural complexity can also affect top down control by mediating predator-prey interactions among smaller-bodied animals. The ability of seagrasses to alter hunting efficiency and, 
by extension, the degree of predator control of herbivores, is predicted to have implications for mesograzer control of seagrass epiphytes (Duffy et al. 2013). For example, in mesocosm experiments where seagrass habitat complexity was manipulated (using flowering vs. simpler non-flowering shoots of Zostera marina), predation rates on the gammarid amphipod Ampithoe valida by teleost predators were reduced by half or more in the complex treatments, which was in turn associated with twice as much $Z$. marina biomass lost as in the simpler treatments (Carr and Boyer 2014). However, this relationship is not uniform; instead, the relationship between predation risk and habitat complexity is mediated by both the hunting mode of the predator and the escape mode of the prey (Wirsing et al. 2010). For example, in terrestrial old field ecosystems in New England, USA, spider predators that use a sit-and-wait hunting strategy hide in grasses, reducing grasshopper use of grasses and increasing their use of nearby herbs (Schmitz 2008). As a result, grasshopper herbivores alter the species on which they feed, changing patterns of top-down control (Schmitz 2008).

Because of the diversity of structural and chemical properties of submerged aquatic macrophytes, primary producer community assembly can mediate the effects of top down control. Seagrass that are associated with other primary producers can experience alterations in the intensity and direction of top-down control as herbivores change consumption rates or feeding preference in the context of a more diverse primary producer community. For example, the association between seagrass and seagrass epiphytes is one of the most important associations in seagrass ecosystems. Epiphytes can rapidly overgrow seagrasses, reducing light penetration and nutrient availability to seagrass tissues. Furthermore, they can reduce seagrass fitness by attracting herbivores to 
seagrasses and mediating herbivore consumption of seagrass tissue. For example, when given a choice between feeding on Posidonia australis blades with or without epiphytes, two species of teleosts (Family Monocanthidae) preferentially targeted the heavily epiphytized leaves, resulting in an eightfold increase in percentage of biomass (including seagrass) removed by these herbivores (Wressing and Booth 2007). Similar feeding preferences are apparent with the sea urchin Lytechnius variegatus when feeding on Thallasia testudinum (Marco-Mendez et al. 2012). The mediation of grazing effects on one macrophyte by another occurs on larger scales as well; in Moreton bay, Queensland, destructive excavation grazing by dugongs removes not only targeted tropical seagrasses such as Halophila ovalis (which quickly recovers), but also the closely associated Zostera muelleri, inhibiting the expansion of this climax seagrass (Preen 1995). Associations between two macrophytes may be also detrimental to a seagrass species if the preferred species is overgrazed and herbivores switch grazing to an associated seagrass to compensate, as sometimes occurs when mesograzers eliminate their algal food supply (Duffy et al. 2001, 2003).

The structural complexity created by macrophytes can also alter grazing pressure on surrounding primary producers if they create refuge for herbivores which are unwilling to venture far from the protection of cover, as occurs in the grazing halos of the Caribbean (Randall 1965). This may have positive or negative influences on associated seagrasses, depending on what the feeding preference of the grazer is, and may result in surprising interactions between macrophytes. For example, drift macroalgae in beds of the eelgrass Zostera marina in the York River, Virginia, USA, may indirectly reduce epiphyte loads on nearby eelgrass leaves by providing refuge for mesograzers, suggesting 
that the presence of competitive macroalgae at low densities may actually facilitate eelgrass persistence (Whalen et al. 2013). Seagrasses that are found in association with relatively unpalatable or chemically defended neighbors may also withstand lower rates of direct grazing by creating microsites of reduced herbivory as has been documented with algae (Hay 1986), though I am unaware of similar studies on seagrasses. The potential for this to alter herbivore pressure likely depends heavily on the spatial scales at which herbivores perceive food quality and the spatial arrangement of such an association. While undeniably complex, understanding the drivers of herbivore feeding preference is absolutely critical to predicting the net effects of consumer control in seagrass ecosystems.

\subsection{The Role of Herbivores}

Herbivores in seagrass ecosystems generally adhere to one of three trophic rolesepiphyte consumers, phytoplankton consumers, and macrophyte consumers. However, herbivores vary widely in their individual capacity to mediate the strength of top-down control through these pathways. Australian seagrass ecosystems feature herbivores that range in size by several orders of magnitude, from tiny arthropods and gastropods only a few millimeters across to marine mammals three meters in length.

Seagrass herbivores can be categorized into three categories based on size: mesograzers, macrograzers and megagrazers. Mesograzers are invertebrates, generally arthropods and gastropods, under $2.5 \mathrm{~cm}$ across (Fig. 1). Though mesograzer densities

vary widely with locale, they can be considered cosmopolitan residents of seagrass beds. Many mesograzers facilitate seagrass persistence through the mutualistic mesograzer 
model, though some consume seagrass tissue (Orth and Van Montfrans 1984, Duffy and Harvilicz 2001, Reynolds et al. 2012, Rossini et al. 2014). Indeed, many invertebrates feed on or bore directly into seagrass tissues or damage them while feeding on associated epiphytes (e.g., Nienhuis and Groenendijk 1986; Wassenberg 1990; Zimmerman et al. 1996; Brearley and Walker 1995; Rueda and Salas 2007; Brearley et al. 2008; Holzer et al. 2011; Reynolds et al. 2012; Carr and Boyer et al. 2014; Rossini et al. 2014). This herbivory can be widespread with significant implications for seagrass productivity and survival. For example, in the Zostera marina beds of San Francisco Bay, USA, consumption by the non-native amphipod Ampithoe valida can deplete seed stocks of this seagrass in a matter of weeks, which may reduce the genetic diversity of perennial beds or even jeopardize the persistence of annual seagrass beds which require seeds for their yearly recruitment (Reynolds et al. 2012). Similarly, the isopod Limnoria agrostisa, widespread throughout Western Australia, burrows into leaf sheathes of Amphibolis griffithi and Posidonia spp., consuming seagrass tissue and damaging or destroying leaf clusters (Brearley et al. 2008). The effects of seagrass consumption by L. agrostisa are substantial, with $40-70 \%$ of leaves being damaged and approximately $40 \%$ of leaf clusters destroyed by this species, illustrating that even small grazers can have surprisingly large effects.

Macrograzers include larger herbivores, such as sea urchins, decapod crustaceans, teleosts like parrotfish (Family Scaridae) and trumpeters (Genus Pelates), and swans (Armitage and Fourqurean 2006, Burkholder et al. 2012, Bessey et al. 2015). These herbivores may target either seagrass tissue or associated epiphytes, though in the case of the latter they still usually remove seagrass tissue in the process, making the impact of 


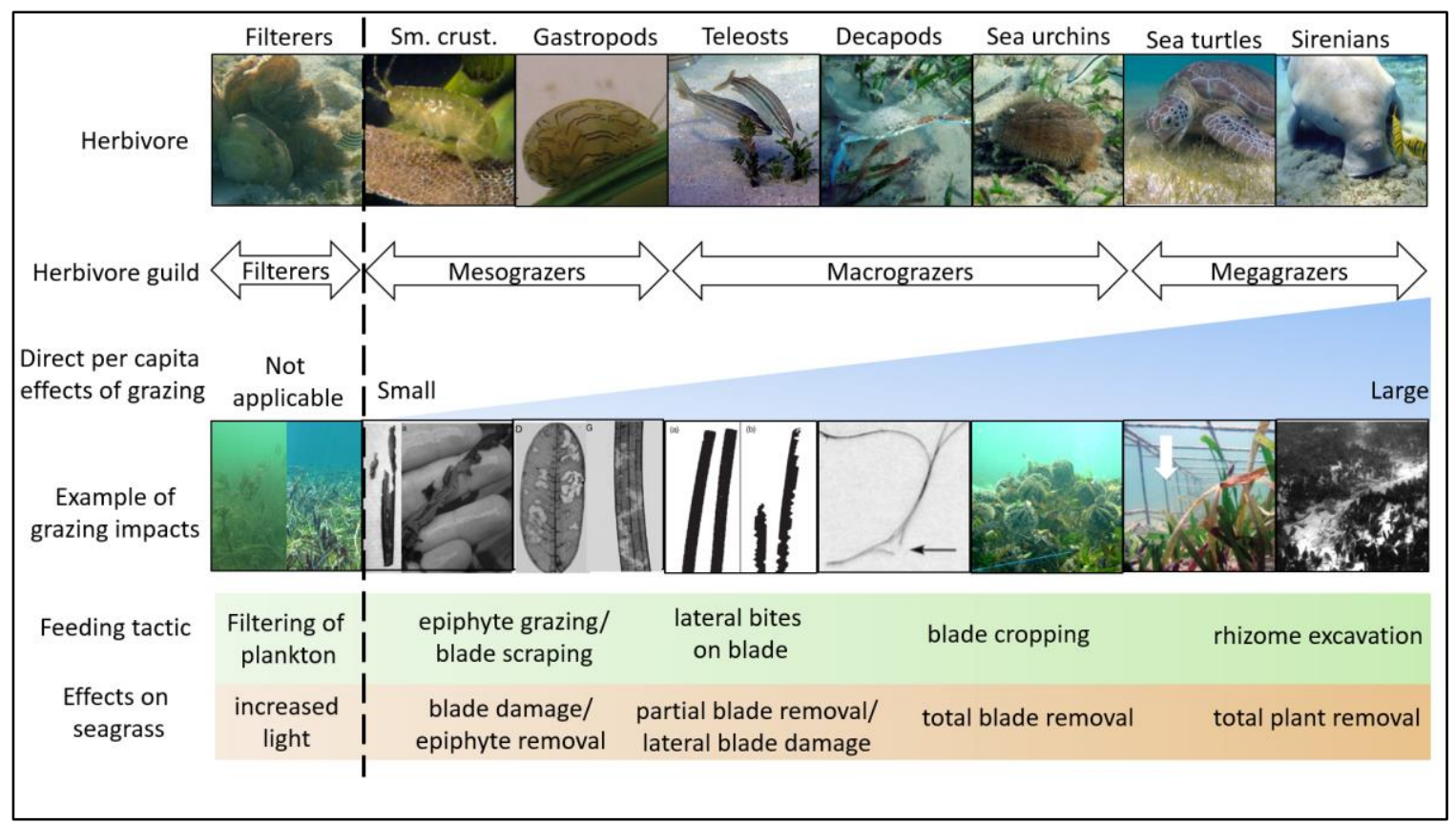

Figure 1. Examples of the types of grazers found in Australian seagrass ecosystems, their feeding tactics, and the resulting impact on seagrass tissue. Tactics are listed in order of increasing per-capita effect on seagrass. Filter feeders are included for completeness, though their grazing of phytoplankton only affects seagrasses indirectly. Photos (clockwise from top left): Shark Bay Ecosystem Research Project (SBERP), Duffy et al. 2014, Rossini et al. 2014, SBERP, SBERP, SBERP, Wikimedia commons, Wikimedia commons, Preen 1995, Burkholder et al. 2013, Eklof et al. 2008, Davis et al. 1998, Goecker et al. 2005, Rossini et al. 2014, Reynolds et al. 2012, SBERP.

seagrass macrograzers generally negative. For example, along the coast of the Gulf of Mexico, USA, the purple urchin Lytechinus variegates is able to consume the majority of aboveground seagrass biomass, sometimes leading to local seagrass extinction (Valentine and Heck 1991, Heck and Valentine 1995, Rose et al. 1999). Similar events have occurred in Australian seagrass meadows and urchin barrens in temperate algal systems are iconic. Multiple instances of overgrazing by sea urchins have contributed to losses of Posidonia spp.-dominated seagrass meadows on the scale of hectares in Cockburn Sound, Western Australia since 1980 (Kendrick et al. 2002). Similarly, aggregations of the 
urchin Heliocidaris erythrogramma denuded 45 hectares of Posidonia habitat in Botany Bay, Australia, between 1979 and 1984 (Larkum and West 1990). In the Torres Straits, reduced seagrass density is correlated with high sea urchin abundance, likely as a result of intense grazing by those urchins (Long and Skews 1996). Urchins can also overgraze Amphibolis antarctica, by targeting leaf meristems (Burnell et al. 2013a). Finally, Australian teleosts like the striped trumpeter Pelates octolineatus can be important consumers of seagrass photosynthetic tissue (Bessey and Heithaus 2015).

Though the ranges for individual species differ, mesograzers and macrograzers of some kind can be found in seagrass ecosystems around Australia. Some Australian macrograzers, like the teleosts Pelates octolineatus, Odax acroptilus, and Haletta semifasciata, or the urchin Heliocidaris erythrogramma, consume substantial proportions of seagrass and epiphytic algae as part of their diet and can, in the case of $H$. erythrogramma, strip entire areas of seagrass above-ground biomass bare (Eklöf et al. 2008, Macarthur and Hydnes 2007, Bessey et al. 2015). Both macrograzers and mesograzers, however, generally target above-ground leaf tissue and leave below ground biomass intact (Fig. 1.)

Because of their relatively high populations in Australian coastal ecosystems, megaherbivores play a more important role in these habitats than they do in well studied seagrass ecosystems of Europe and North America (Lanyon et al 1989). Specifically, Australian seagrass ecosystems are home to two species of megaherbivores: green turtles (Chelonia mydas) and dugongs (Dugong dugon). Though both megaherbivores consume seagrass tissue, their grazing tactics generally differ. When consuming seagrass, green turtles primarily remove above ground biomass by cropping seagrass leaves, though in 
some areas of the world they will excavate belowground biomass as well (Christanen et al. 2014). Conversely, dugongs commonly excavate seagrass beds, particularly when Australian tropical seagrass such as Halophila ovalis and Halodule uninervis are present (Anderson 1986, Preen 1995, Masini et al. 2001). During excavation, dugongs dig into the sediment to target seagrass rhizomes, potentially destroying large areas of seagrass beds (e.g., Preen 1995, Fig 1). This grazing tactic, combined with the dugong's large size, relatively high metabolic rate, and obligate seagrass diet, means dugong-seagrass interactions can be very strong. Indeed, in Shark Bay, Western Australia, dugong excavation results in the consumption of approximately $50 \%$ of primary production in beds of the pioneer seagrass Halodule uninervis (Masini et al. 2001). When such seagrasses are unavailable or when risk of predation makes excavation grazing unappealing, dugongs will instead crop the above ground biomass of temperate seagrasses such as those from the genera Zostera or Amphibolis (Anderson 1986, Preen 1995, Wirsing et al. 2007 a). This has important implications for their impacts on seagrass community structure and ecosystem dynamics (see below).

Finally, suspension feeders play important, if underappreciated, roles in the top down control of seagrass ecosystems. Consisting of a variety of taxa including sponges, bivalves, gastropods, crustaceans, and ascidians, this herbivore group does not actually consume seagrass. Suspension feeders are, however, important herbivores in seagrass ecosystems for a similar reason to facultative mesograzers- they control primary producers (specifically phytoplankton) that compete with seagrasses for light (Peterson and Heck 2001, Newell 2004). The effect of phytoplankton removal on seagrasses is hard to quantify and disentangle from the more general benefit suspension feeders have 
on water clarity since suspension feeders also remove suspended sediment and particulate organic matter. However, the benefit this herbivore group has on seagrasses can be surprisingly strong due to the high light requirement of seagrasses as a group (Dennison et al. 1993). For example, mathematical models estimate that uniform densities of the Eastern Oyster Crassostrea virginica as low as $25 \mathrm{~g}$ dry weight $\mathrm{m}^{-2}$ reduces suspended sediment concentrations by almost an order of magnitude (Newell and Koch 2004). In areas where phytoplankton loads are high, suspension feeders probably play important, if indirect, roles as seagrass facilitators.

Because the net effects of herbivores in seagrass ecosystems is heavily influenced by which grazing pathways dominate in that system, it is important to understand where specific pathways are most likely to dominate, and by extension, the geographic ranges of important herbivores. Mesograzer control of epiphytes is thought to be widespread and may overshadow the ecological effect of direct seagrass consumption in many places (see Hughes et al. 2004 and Valentine and Duffy 2006). However, the dominance of the mesograzer pathway relative to other grazing pathways is likely to be limited to temperate seagrass habitats within Australia. This is due to the presence of megagrazers in tropical and subtropical Australian seagrass ecosystems, as well as the generally pioneer seagrass species that typify tropical Australian waters, the ephemeral nature of which limits the effect of epiphyte colonization. Even within temperate seagrass ecosystems, whether the net effect of herbivores is facultative or destructive towards seagrasses depends on the relative dominance of macrograzers and destructive mesograzers against facultative mesograzers and filter feeders. Indeed, most teleost and urchin macrograzers on which investigations into top down control have been done have 
subtropical to temperate distributions (Fig. 2). Subtropical areas where ranges between megagrazers and macrograzers interact may exhibit additional complexity because of the co-occurrence of these different guilds. This range separation means that in tropical Australian systems, megagrazers should generally have a stronger potential to dominate top-down control than macrograzers or mesograzers, while in temperate habitats clear dominance of herbivore pathways are probably more elusive. All of these herbivore groups overlap in subtropical habitats, however, further complicating predictions about which pathways will dominate the effects of top down control in these habitats. For example, multiple herbivore exclosure studies in Shark Bay suggest that megagrazer and macrograzer pathways may each dominate in different habitats of the same ecosystem (Burkholder et al. 2013, Bessey et al. 2016).

\subsection{The Role of Predators}

Predators exert top-down control in seagrass ecosystems not only by regulating the populations of their prey, but also by altering the intensity, target, and spatiotemporal patterns of herbivory (Heithaus et al. 2008). When this control impacts trophic levels below that of their prey, a trophic cascade occurs (Paine 1980). The potential role of predators in shaping patterns of top-down control by seagrass herbivores has been recognized for decades. As has been mentioned before, for example, Randall (1965) suggested that grazing halos around Caribbean patch reefs were due to reef-associated fishes that targeted seagrass but were unwilling to venture far from the safety of their refuges. Since then, meta-analysis has indicated that trophic cascades tend to be strongest in benthic marine ecosystems (Shurin et al. 2002, Borer et al. 2005). 


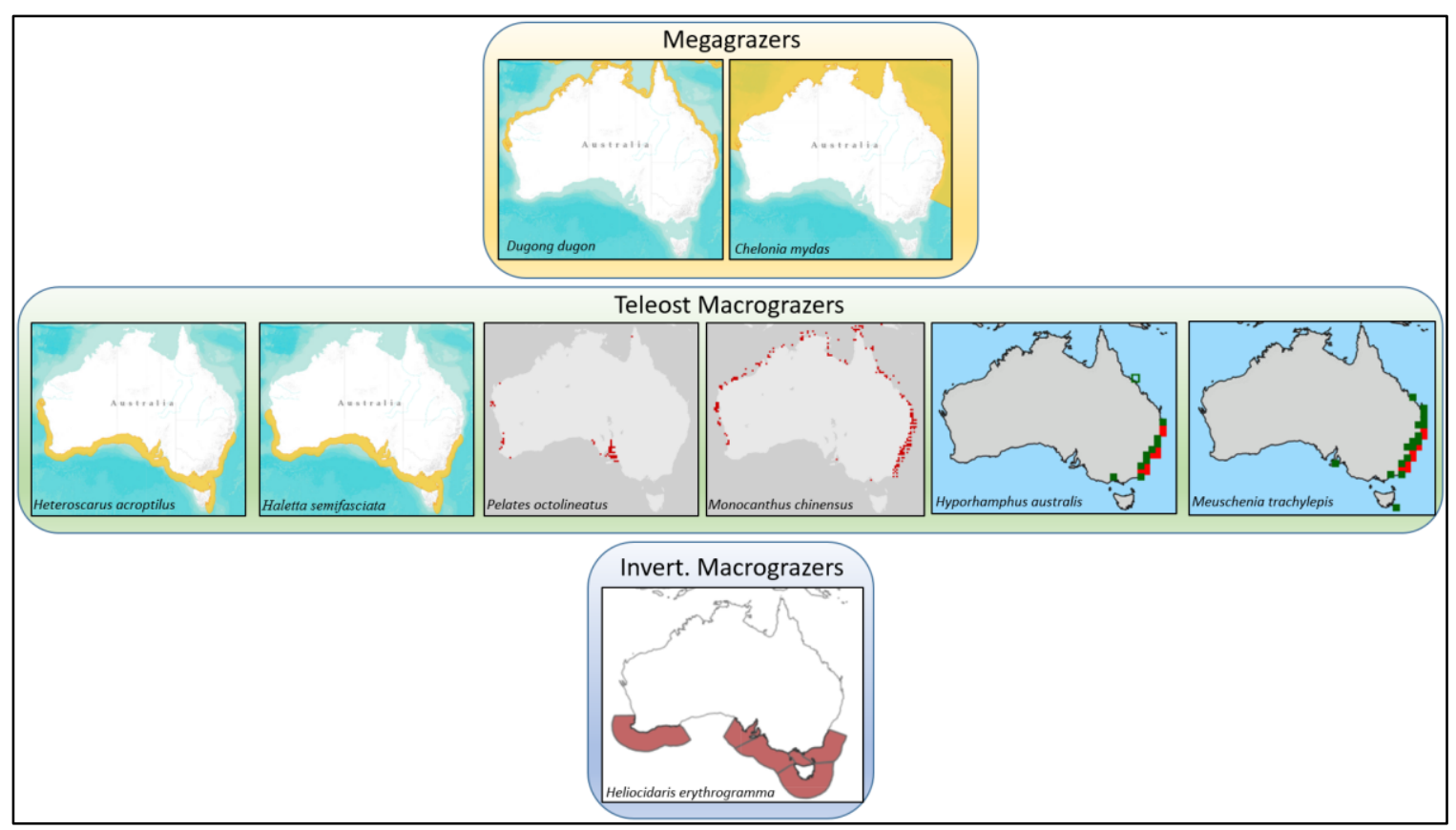

Figure 2. Known distributions of representative Australian seagrass megagrazers and macrograzers. Ranges of macrograzers, however, may reflect geographically restricted research effort rather than true geographic range separations between macrograzers and megagrazers. Map sources by row, left to right: IUCN, IUCN, Encyclopedia of Life, Aquamaps.org, Marinespecies.org.

Traditionally, trophic cascades were thought to operate exclusively through lethal predator effects in which increases in predator abundance reduce mesoconsumer density through predation and, as a result, also reduce pressure on associated resource species (Lima 1998). Predators, however, elicit myriad changes in prey behavior including fearinduced habitat shifts, reduction in foraging rates, or changes in diet (e.g., Randall 1965, Lima 1998, Brown et al. 1999, Peacor and Werner 2001, Heithaus and Dill 2002, 2006, Brown and Kotler 2004) and traits including morphology and physiology (e.g., Creel 2007). These "risk effects" of predators can initiate or enhance trophic cascades through trait-mediated indirect interactions (i.e., TMIIs, Werner and Peacor 2003, Dill et al. 2003, Schmitz et al. 2004, Preisser et al. 2005). 
One type of TMII, a behaviorally mediated indirect species interaction (BMII; sometimes referred to as a behavior-mediated trophic cascade; BMTC), occurs when changes in a property of one species (the "initiator") cause a behavioral shift in a "transmitter" species, which in turn induces a change in a property of a third species (the "receiver") (Schmitz et al. 1997, Dill et al. 2003). BMII have received considerable attention recently in terrestrial, freshwater, and intertidal marine systems and appear to be capable of affecting populations and communities at magnitudes equal to, or greater than, those of lethal effects of predators (e.g., Werner and Peacor 2003, Schmitz et al. 2004, Preisser et al. 2005). The power of such non-consumptive predator effects stems from their ability to affect many prey simultaneously, and sometimes through the ability of prey to exhibit compensatory population growth in response to mortality from consumption by predators. Additionally, in some situations BMII can reverse the sign of indirect interactions between top predators and basal resources in food chains with an odd number of trophic levels relative to those predicted by lethal effects of predators alone (Dill et al. 2003, Heithaus and Dill 2006, Wirsing et al 2007c). Importantly, even if predators rarely consume or have minimal effects on the equilibrium population sizes of mesoconsumers, they may still trigger trophic cascades through non-lethal mechanisms by altering where and at what rate mesoconsumers exploit resource species (Werner and Peacor 2003, Schmitz et al. 2004, Preisser et al. 2005, Heithaus et al. 2008). Finally, the effects of direct predation and risk effects interact with one another to enhance overall predator effects and this interaction may account for the majority of predator impacts (Werner and Peacor 2003, Heithaus et al. 2012). 
Most trophic cascades recorded in Australian marine ecosystems have been from temperate and tropical algae reefs (Pinnegar et al. 2000), not seagrass ecosystems. However, this may be due not to a lack of trophic cascades in seagrass ecosystems so much as to a gap in research effort. Indeed, long term studies in Shark Bay, Western Australia, have identified multiple trophic cascades (and BMIIs) in a subtropical seagrass ecosystem. Shark Bay's apex predator, the tiger shark (Galeocerdo cuvier) induces habitat shifts at multiple spatial scales in both herbivores and mesopredators. Specifically, dolphins (Tursiops aduncus), dugongs, and cormorants (Phalacrocorax varius) all shift from foraging primarily in productive shallow seagrass habitats when sharks are scarce to foraging mainly in less productive, but safer, deep habitats when shark densities are high (Heithaus and Dill 2002, Heithaus 2005, Wirsing et al. 2007b). Dolphins and dugongs that continue to forage over shallow habitats when sharks are present largely abandon the highly dangerous interior portions of shallow banks that they used when sharks were scarce, in order to have easy escape options near bank edges (Heithaus and Dill 2006, Wirsing et al. 2007c, Fig. 3). Similarly, green turtles in good body condition forage almost exclusively along bank edges, where seagrass quality is lower, when sharks are present but move toward interior microhabitats, with higher seagrass quality, when tiger sharks are scarce (Heithaus et al. 2007). Furthermore, tiger sharks alter dugong foraging tactics, limiting destructive excavation grazing that has been recorded to destroy hectares of seagrass elsewhere (Wirsing et al. 2007a, Preen 1995). Cormorants, the escape success of which is independent of benthic terrain, seek to minimize predator encounters and increase use of seagrass meadow interiors when sharks are abundant (Fig. 3). None of these spatiotemporal shifts can be explained by variation 
in food availability, water temperature, or other factors. In the case of megaherbivores, these predator effects cascade down to the seagrass bed, altering which seagrasses dominate on bank edges (Bukholder et al. 2013, Fig. 3). These species-specific responses to predation risk illustrate the complex and sometimes counterintuitive nature of predator prey interactions in seagrass ecosystems, and the need to consider properties of predators, prey, and landscape in predicting the effects of antipredator behavior.

These studies exemplify the potentially dramatic effects predators can have in seagrass ecosystems through regulating the behavior of their prey, yet the dominant predators and herbivores in Australian seagrass ecosystems differ across the continent. While large-bodied sharks are undoubtedly the largest apex predators commonly found in most seagrass ecosystems, dolphins are also important and widespread upper trophic level predators. Several species of dolphins are found in coastal seagrass ecosystems of Australia - Indo-Pacific bottlenose dolphins (Tursiops sp.) and humpback dolphins (Sousa sahulensis ) being common. Both species are piscivores, and because of high mammalian metabolic rates likely consume a large number of teleosts that may be important in the dynamics of seagrass ecosystems. In the subtropical Shark Bay seagrass ecosystem, Tursiops cf. aduncus preys upon striped trumpeters (Pelates octolineatus) (Heithaus and Dill 2002), the dominant teleost grazers (Heithaus 2004, Burkholder et al. 2012). Given the high population densities of dolphins in Shark Bay (Preen et al. 1997, Heithaus and Dill 2002) it is possible that dolphins could indirectly influence seagrass ecosystems through modifying the population sizes or spatiotemporal patterns of foraging by $P$. octolineatus. Unfortunately, little work has focused on the potential for dolphins to impact the dynamics of fish populations within seagrass ecosystems or how those 
impacts may cascade to structure seagrass communities. Similarly, pinnipeds such as Australian sea lions (Neophoca cinerea) and fur seals (Arctocephalus spp.), may have been important predators in temperate Australian seagrass ecosystems, but their population sizes are much reduced from historical levels and the potential role of pinnipeds in structuring Australian seagrass ecosystems has not been explored. While both pinniped species tend to forage in offshore habitats, using coastal habitats for transit and rest, some individual Australian sea lions do forage consistently in coastal seagrass habitats (Lowther et al. 2011) and could exert top-down impacts on fishes of seagrass beds. This possibility remains largely unexplored, and studies of the potential top-down roles of predatory marine mammals in Australian seagrass ecosystems remains an interesting and potentially significant avenue of inquiry.

Unsurprisingly, many teleosts and smaller elasmobranchs may play important roles in Australian seagrass ecosystems. Indeed, small sharks ( $<2 \mathrm{~m}$ total length), rays, and teleosts can be locally abundant in Australian seagrass communities (e.g., White and Potter 2004, Simpfendorfer and Milward 1993). While some of these predators are actually omnivorous, consuming primary producers in addition to animal matter (e.x. $P$. octolineatus, Belicka et al 2012, Burkholder et al. 2012, Bessey and Heithaus 2015), other mesoconsumers feed on a diversity of prey including infauna, cephalopods, crustaceans, and worms, which may initiate trophic cascades. For example, stingrays may initiate three-step trophic cascades under which consumption of filter-feeding bivalves results in increased phytoplankton load, reducing light penetration to seagrass tissues. Indeed, there is strong evidence for the capability of batoids to exert top down control over bivalves when these predators are locally abundant (e.g., Peterson et al. 
2001, Myers et al. 2007), though to our knowledge empirical work on the indirect effects of batoids on seagrass are lacking. Similarly, marine birds have the potential to exert top-down control through direct predation and risk effects (i.e., Bessey and Heithaus 2013). Like predatory marine mammals, marine birds such as cormorants have high metabolic rates and can exist at high densities in seagrass ecosystems (e.x. in Shark Bay, Heithaus 2005, Bessey et al. 2016). Furthermore, the proportion of teleosts in the diets of cormorants in Australia can reach 90\% or more (del Hoyo et al. 1992, Blaber and Wassenberg 1989, Humphries et al. 1992), and daily consumption rates can be $15 \%$ of body mass or more (Humphries et al. 1992). Interestingly, the role of these mesopredators in generating top-down control (specifically trophic cascades) remains largely unexplored in Australian seagrass ecosystems.

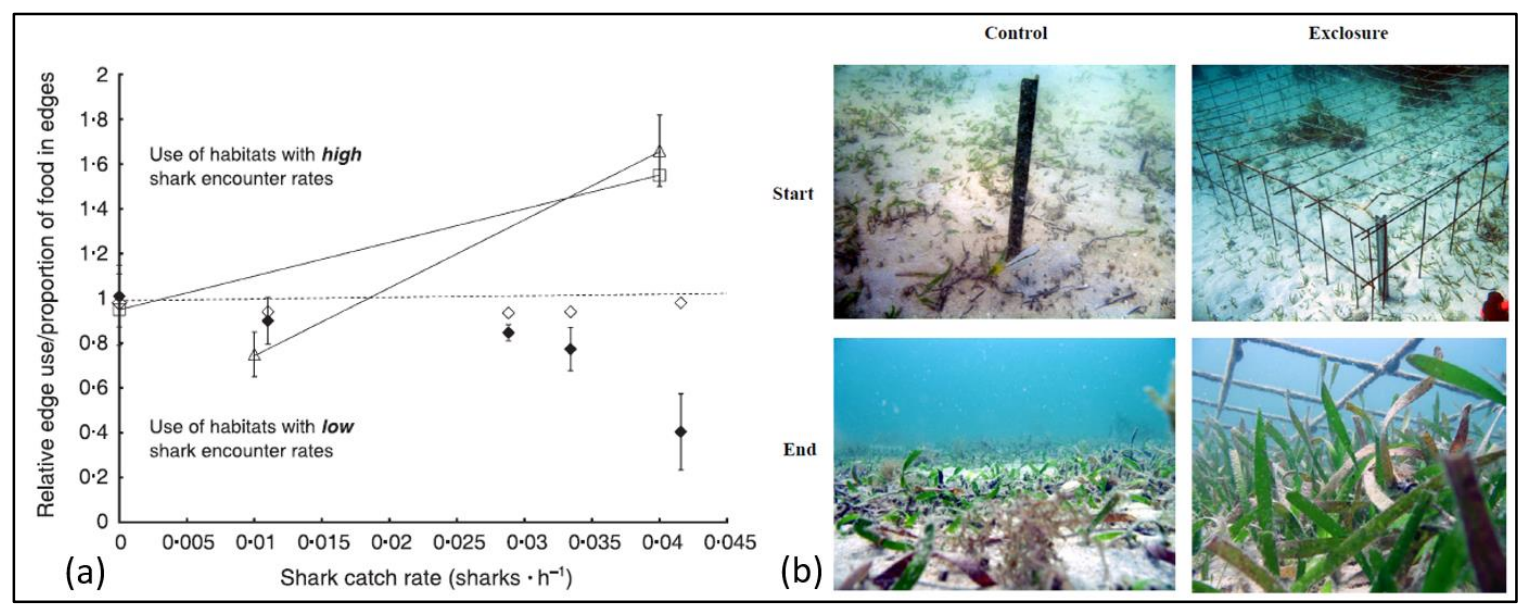

Figure 3. (a): Change in habitat use of dugongs (open triangles), Indo-Pacific bottlenose dolphins (open squares), and Piedcormorants (closed diamonds) associated with changes in abundance of large sharks in Shark Bay, Western Australia. Open diamonds represent the food supply of cormorants. The dashed line represents expected proportion of habitat use if fauna are ideally distributed in relation to their food supply; values above the line represent over-use of seagrass edge habitats, where the chance of tiger shark encounters is highest. (b): Megagrazer exclosure experiments in seagrass edges, which confirm that risk-sensitive habitat use patterns of megaherbivores translate to increased top-down control of seagrass edge habitats. Reproduced from Heithaus et al. 2009 and Burkholder et al. 2013. 
Trophic cascades have been recorded or proposed in seagrass ecosystems at multiple scales and trophic levels worldwide, from control of seagrass associated invertebrates by predatory teleosts (Heck and Valentine 1995, Heck et al. 2000, Lewis and Anderson 2012, Carr and Boyer 2014) to behavioral control of megaherbivores and secondary predators by tiger sharks (Heithaus et al. 2012, Burkholder et al. 2013). As with herbivores, however, predators do not have equal capacity to exert top-down control or trophic cascades in seagrass ecosystems. Because herbivores influence seagrass communities through two main avenues (direct consumption of seagrass biomass and consumption of seagrass competitors), predators ultimately exert top-down control through these two pathways. In areas where megagrazers are dominant, large sharks are the only apex predators likely to have significant capability to structure seagrass ecosystems through top-down control. Conversely, if smaller teleost herbivores mediate a direct seagrass consumption pathway, intermediate predators such as dolphins, pinnipeds, cormorants and small sharks may all influence the potential for a cascade to occur. Finally, because so many members of the epiphyte-consuming mesograzers are small-bodied invertebrates, myriad intermediate predators may exert top-down control. Though studies evaluating predator control of megagrazers are exceedingly rare, the prominence of megaherbivores in tropical and subtropical Australian seagrass ecosystems means that large-bodied sharks may be, or may have been, disproportionately important to structuring these ecosystems. For example, the loss of large sharks is hypothesized to be important in allowing the release of sea turtles in several seagrass ecosystems that has resulted in considerable declines in seagrass biomass (e.g., Heithaus et al. 2014) and potential ecosystem collapse (Christianen et al. 2015). Conversely, endothermic 
intermediate predators like dolphins and pinnipeds may be more important to structuring temperate seagrass ecosystems.

\subsection{The Role of Food Web Structure}

To understand the role of top down control, particularly trophic cascades, it is helpful to be able to predict when and where such cascades are most likely to occur. Ecological theory predicts that food web structure, specifically food web length and complexity, will have important effects on the strength and nature of such top down control. In very simple food webs, the number of links between apex predators and primary producers has implications for whether herbivore control on primary producers is strong or weak. Chains with an odd number of linkages should yield weak herbivore control on primary producers and a facultative relationship between apex predators and primary producers through a trophic cascade. Conversely, chains with an even number of levels should yield strong herbivore control of primary producers and an inhibitive effect of apex predators on primary producers as those larger predators regulate intermediate predators, which in turn control herbivores. Assuming that populations are density dependent and limited by food or predation, simple food webs are most sensitive to food chain length because trophic cascades remain strong, having little opportunity to attenuate and diffuse through multiple food web pathways (Strong 1992). Accordingly, ecosystems with simple trophic structure are more likely to suffer from reversals in the "direction" of trophic cascade effects and concomitant changes in the strength of herbivore control on plants if the initiator species (a predator) is removed. 
While food chain length influences the net direction of the effect apex predators and herbivores will have on primary producers, food web complexity can often influence how strong those effects can be. This is because the strength of trophic cascades is dependent on the strength of species-species interactions- and the simple construction of food chains leads them to be more likely to have strong species interactions than complex food webs. In simple linear food webs (i.e., food chains), the interaction strengths between predators, herbivores, and resource species is necessarily strong, because consumptive relationships are "unified" (sensu Strong 1992) into single species-species interactions (Fig. 4). Complex food webs, however, have multiple trophic or interaction pathways from apex predators to primary producers, and these pathways may not have the same number of links. This can diffuse predator effects through many avenues, resulting in fewer of the strong species-species interactions that are typical of linear food webs and attenuating the overall indirect effects of a predator on primary producers (Fig. 4). While species diversity increases food web complexity, generalists and omnivores also do so by consuming organisms from multiple trophic levels, creating additional pathways through which predator control can operate. For example, if herbivores are generalists, their negative effects on primary producers may be attenuated through their indiscriminate consumption of resource species, reducing the strength of competitive interactions among seagrasses or between seagrass and epiphytic or benthic algae.

Though increased food web complexity likely reduces the probability of strong species-species interactions (and by extension, strong trophic cascades), they can still occur. But what makes a strong interaction between species? In general, strong interactors are species that are "efficient" (Strong 1992); they may consume more prey 
per capita, or have strong non-consumptive effects. Most seagrass food webs display some trophic complexity and tend to have multiple trophic channels from apex predators to primary producers- but they can also be dominated by channels with strong interactions that remain undiffused, increasing the likelihood of trophic cascades. This is exemplified in tropical seagrass ecosystems dominated by megagrazers like adult and large juvenile green turtles and dugongs that are almost exclusively at risk from tiger sharks (e.g., Heithaus et al. 2008b, Heithaus 2013; Wirsing et al. 2007a,b,c). The loss of this top predator could not be compensated for by increased predation rates or predation risk from another predator. Megagrazers, in turn, tend to have strong per-capita effects on seagrasses and are thus strong interactors with these primary producers (i.e., Fig 3, 4). When this short, three-link chain is the dominant trophic pathway, seagrass ecosystems are prone to strong trophic cascades- and by extension, highly vulnerable to predator removal. While this pathway has been lost from many tropical and subtropical seagrass ecosystems due to overharvest of megagrazers, it is likely to still dominate throughout much of tropical and subtropical Australia where megagrazer populations remain intact. Consequently, the loss of apex predators like large sharks in these ecosystems may have disproportionate effects on the primary producers of Australian seagrass ecosystems (e.g., Burkholder et al. 2013, Heithaus et al. 2014).

\section{Effects of Consumers on Seagrass Communities}

Consumers can structure seagrass communities through consumption or facilitation of primary producers, alteration of community composition, or through influencing bottom-up processes. These forms of top-down control, by altering the 
properties of seagrass habitats, can drive seagrass ecosystem processes, functions and services at local, regional, and global scales.

\subsection{Ability of Consumers to Facilitate Seagrasses}

Seagrasses provide substrate for epiphytes, which compete with them for resources such as light. High nutrients often increase epiphyte and phytoplankton loads with negative impacts for seagrasses; indeed, eutrophication is one of humanity's most pervasive stressors to seagrass ecosystems (Waycott et al. 2009). By consuming epiphytes and plankton, mesograzers and suspension feeders have the capacity to attenuate the negative effects of eutrophication in seagrass ecosystems (Peterson and Heck 2001, Valentine and Duffy 2006). The role of facultative mesograzers has been particularly well supported with empirical data- historically in the laboratory and mesocosms, but increasingly in the field. Early caging work in Western Australian Posidonia sinuosa beds showed that gastropods reduce epiphyte biomass by almost $50 \%$, while amphipods have minimal effects on epiphyte biomass (Jernakoff and Nielsen 1997). Novel cage-free approaches, using slow-release pesticides, have made manipulating invertebrate densities in benthic marine ecosystems easier without introducing caging artifacts (Poore et al. 2009). These experiments, several of which have been conducted in Australian seagrass ecosystems, confirm the importance of invertebrate mesograzers to epiphyte control. For example, exclusion of amphipod mesograzers from seagrass meadows in Cockburn sound, Western Australia, resulted in significant increases in epiphyte biomass in some seagrass species, though this did not translate to increases in seagrass biomass over the experiment duration (7 weeks) (Cook et al. 2011). Similar cage-less experiments in the Posidonia 
angustifolia beds of Lady Bay, South Australia that manipulated mesograzer densities and nutrient levels showed that such grazers are able to compensate for increased nutrient additions by increasing their per-capita consumption of seagrass epiphytes (McSkimming et al. 2015), mirroring findings elsewhere (i.e., Chesapeake Bay, USA, Reynolds et al. 2014). Indeed, in general, mesograzer presence reduces epiphyte loads approximately as much as nutrient enrichment in the water column increases them: effect sizes are often

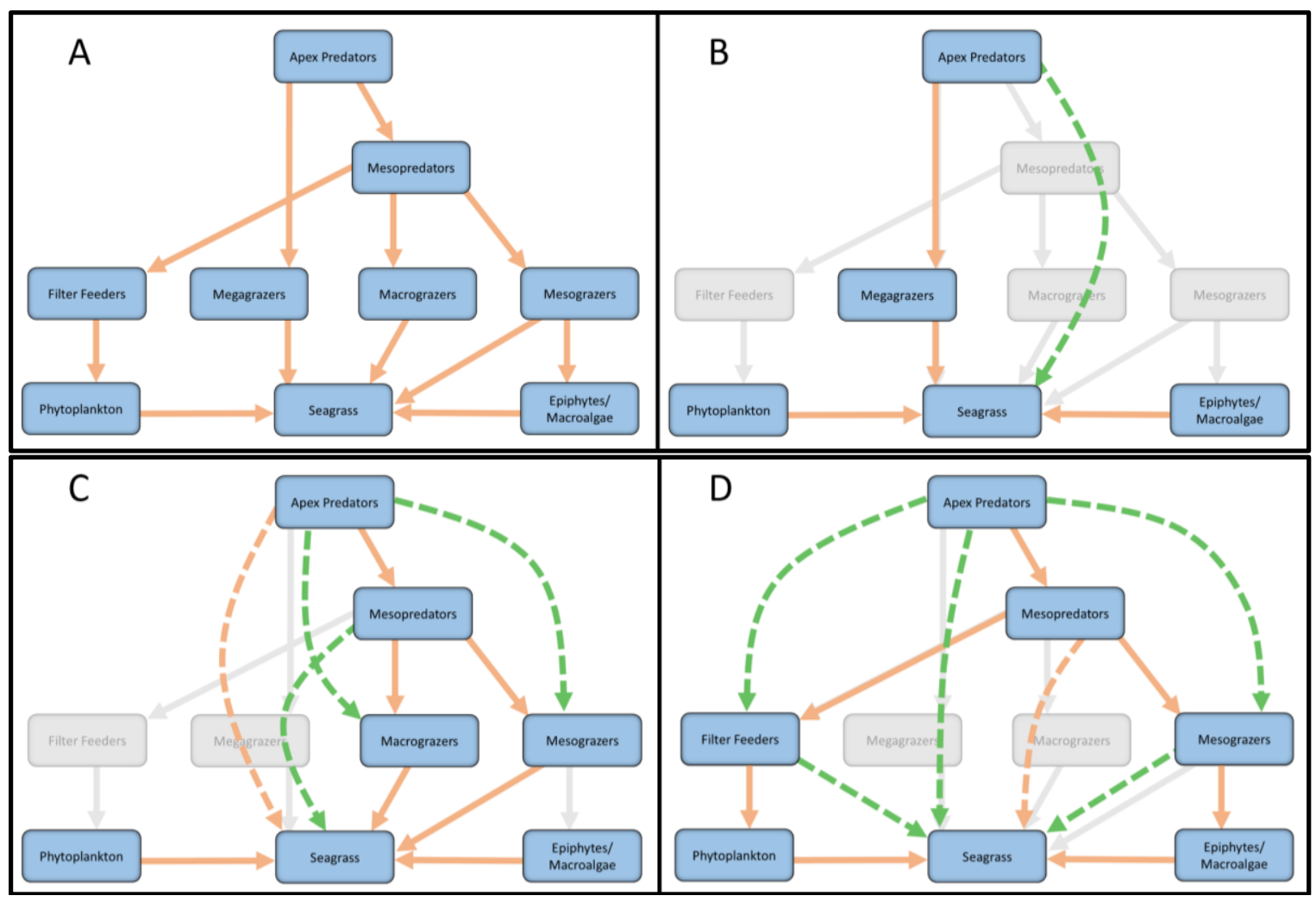

Figure 4. Conceptual food webs illustrating the main direct and indirect pathways through which top-down control operates in seagrass ecosystems. An intact seagrass community (A) showing direct effects only; (B) a web dominated by the megagrazer pathway; (C) a web dominated by more diffuse mesopredators and smaller seagrass herbivores; (D) a pathway dominated by facultative herbivores like filter feeders, epiphytivores, and algavores. Colors indicate positive (green) or negative (orange) effects of one group on another with arrows denoting direction of effect. Solid and dashed lines indicate direct and indirect effects respectively; greyed out boxes and lines indicate minor consumers and pathways. 
similar in magnitude but opposite in effect (Hughes et al. 2004, Heck and Valentine 2006).

Mesograzers, and to a lesser degree filter feeders, have received the most attention for their ability to mitigate nutrient enrichment effects, but other consumers are able to do so as well. Larger herbivores, even if they do not target epiphytes, can also be strong controllers of epiphyte biomass in the face of eutrophication (Heck et al. 2000, Goecker et al. 2005, Brodeur et al. 2015, Reynolds et al. 2014). For example, clipping experiments mimicking green turtle grazing in beds of Halodule uninervis off of the Derawan Island, Indonesia, almost doubled seagrass production in the face of increased nutrient loads, and may be an important mechanism for exporting excess nutrients from the system, thereby limiting epiphyte overgrowth (Christianen et al. 2012). This topdown facilitation may act as a critical source of resilience for seagrass communitiesparticularly those near urban centers. Some have even suggested that eutrophication impacts are so large in modern seagrass ecosystems because consumer populations have been largely compromised (Burkepile and Hay 2006, Heck and Valentine 2007). Indeed, factorial experiments in Chesapeake Bay, USA indicated that nutrient additions had minor effects on seagrass productivity when in the presence of grazers, but that grazer exclusion resulted in a sixfold increase in epiphyte biomass and a $65 \%$ decrease in seagrass biomass (Reynolds et al. 2014). Perhaps most importantly, these two factors interacted significantly; in the presence of grazers, nutrient additions increased seagrass biomass, while in the absence of grazers, additions reduced biomass (Reynolds et al. 2014). As a result, maintenance of grazer populations has been suggested as a possible tool to combat the negative effects of eutrophication (e.g., Hughes et al. 2004, Reynolds 
et al. 2014). This suggests that successful seagrass restoration in eutrophic ecosystems will require a combined effort to reduce nutrient loads and maintain healthy populations of epiphyte herbivores (Reynolds et al. 2014). Such facilitation, however, probably has limits (Ghendini et al. 2015); for example, in rocky shore communities of the northwest Atlantic Ocean and Baltic Sea, increased nutrient loads reduce the ability of herbivores to control filamentous algae (Worm and Lotze 2006). Further work is needed to determine when mesograzers are able to control eutrophication derived epiphyte overgrowth, and under what conditions such control results in measureable benefits to seagrass (Cook et al. 2011), as the effects of epiphyte reduction may attenuate at the seagrass-epiphyte interface, and because mesograzers can also have substantial negative effects on seagrass production (e.g., Lewis and Anderson 2012). Lastly, grazers may also facilitate particular seagrass species by removing non-epiphyte competitors such as macroalgae or other seagrasses (see section 3.3, below).

In addition to stimulating seagrass production by inducing compensatory responses to low levels of direct herbivory and through removing competitive epiphytes, consumers can exert top down control by facilitating seagrass reproduction or seed dispersal. Though many organisms are destructive seed predators of seagrass ecosystems, highly mobile seed consumers can also facilitate dispersal and sexual reproduction (Sumoski and Orth 2012). Herbivores may even act as pollinators, as is thought to occur with crustacean and polychaete mesograzers in Thalassia testudinum beds (van Tussenbroek et al. 2012). Finally, through active seed dispersal, consumers have the ability to increase genetic connectivity between seagrass communities or 
promote colonization up currents- something that can be difficult to achieve with passive dispersal alone.

\subsection{Ability of Consumers to Damage Seagrasses}

While top down control can facilitate seagrasses, work over the past few decade has highlighted the detrimental potential of direct seagrass herbivory. Seagrasses generally display a nonlinear response to grazing; low and moderate grazing can stimulate growth and production up to a threshold, while some seagrasses simply resist or tolerate low grazing intensity; however, intense grazing can cross this threshold and jeopardize seagrass persistence (Valentine et al. 1997, Cebrian et al. 1998, Vergés et al. 2008). Concentrated grazing pressure which inhibits seagrass ecosystem function is known as overgrazing (sensu Eklöf et al. 2008). Overgrazing is most common when herbivore densities peak or where herbivore feeding tactics are particularly destructive. These events, though generally rare and usually temporally restricted, can generate strong and lasting detrimental effects on seagrass ecosystems- in extreme cases, even resulting in a complete ecosystem change (see examples in Eklöf et al. 2008). All three main herbivore groups that consume seagrasses (mesograzers, macrograzers, and megagrazers) are capable of overgrazing them (e.g., Nakaoka 2002, 2005, Holzer et al. 2011, Lewis and Anderson 2012, Preen 1995, Eklöf et al. 2008).

In addition to consuming seagrass photosynthetic tissue, herbivores can also impact seagrass communities by reducing seagrass reproductive success. Mesograzers and macrograzers feed on seagrass reproductive tissues such as inflouresences, seeds, and fruits, either directly off of the plant or from the sediment surface (e.g., Wassenberg 
1990, Holbrook et al. 2000, Orth and Kendrick 2006, Vergés et al. 2007, Reynolds et al. 2012). Some species like Thallasia testudinum and Halodule wrightii appear to be pollen limited- so herbivores may be important in limiting reproduction in these species if consumption rates of male flowers are high (van Tussenbroek and Muhlia-Montero 2013). In some cases, consumptions of flowers, fruits and seeds can result in large reductions in seed populations and thus reproduction via seeds. For example, tanaied crustaceans consume 14-27\% of the seeds of Zostera marina and Z. caulescens in Japanese seagrass beds (Nakaoka 2002), while crustacean seed predators in southern California, USA, consume infloresences and up to half of Phyllospadix torreyi seeds (Holbrook et al. 2000). Similarly, in seagrass beds off of Rottnest Island, Western Australia, crustacean seed predators can remove more than half of tethered Posidonia australis seeds in a single day (Orth and Kendrick 2006).

Finally, negative top-down control of seagrasses can occur through nonconsumptive means. By using seagrass as shelter, some animals cause damage to seagrass shoots with surprising frequency (e.g., van Tussenbroek and Brearley, 1998; Brearley, Kendrick andWalker, 2008). For example, in a Mexcian Carribbean lagoon, the isopod Limnoria simulate burrows into the leaf sheathes of Thallasia testudinum, where it reproduces; average infestation rates can approach $50 \%$ and cut leaf growth by $30 \%$ when infestation rates on an individual ramet are high (van Tussenbroek and Brearley 1998). Instead of burrowing into seagrasses, other invertebrate consumers use seagrass as substrate, inhibiting light penetration to seagrass tissues and reducing growth (e.g., Long and Grosholz 2015). Through excavation of sediment and disturbance of seagrass rhizomes, stingrays can damage, destroy, or inhibit the expansion of seagrass 
beds while foraging for bivalves (e.g., Orth 1975). These examples illustrate the diversity of non-consumptive avenues through which top down control can inhibit the growth, expansion or persistence of seagrass ecosystems. However, further work is needed to evaluate the capability for such forces to structure seagrass communities relative to consumptive effects, which are better studied.

\subsection{Effects of consumers on seagrass community composition}

In general, the impacts of top down control on seagrasses are not uniform in communities with multiple seagrass species and may result in shifts in community composition and standing biomass. Such impacts are most pronounced in diverse seagrass communities of the subtropics. As previously mentioned, herds of dugongs in subtropical Moreton Bay, Queensland, focus their feeding on mixed species seagrass beds, primarily excavating the nutrient rich tropical seagrass Halophila ovalis but incidentally removing the climax species Zostera muelleri. Dugongs facilitate $H$. ovalis beds, which are able to recover quickly from grazing. Conversely, grazing prevents the expansion of Z. muelleri, which is disturbance-intolerant. Indeed, dugong exclusion over six months resulted in a five-fold increase in the shoot density Z. muelleri and a six-fold decrease in the pioneer species $H$. ovalis, while simulated dugong grazing increased shoot densities of $H$. ovalis at a rate five times faster than for $Z$. muelleri. Such feeding behavior can keep seagrass ecosystems in early successional, pioneer states dominated by fast growing, disturbance tolerant species (Preen 1995, Aragones and Marsh 2000).

Green turtles can also shift the species composition of seagrass communities. In India's Lakshadweep Archipelago, grazing by high densities of green turtles exceeded 
production of the dominant seagrass species Thalassia hemprichii and Cymodocea rotundata, and resulted in reduced shoot elongation rates and a community shift from the preferred climax seagrass Thalassia hemprichii to a pioneer species Cymodocea rotundata (Kelkar et al. 2013a). Similarly, a 600-day megagrazer exclusion experiment in seagrass habitats in Shark Bay, Western Australia, resulted in an eightfold decrease in shoot density of the pioneer seagrass Halodule uninervis and a concurrent doubling in shoot density of the larger seagrass Cymodocea angustata (Burkholder et al. 2013). These cages excluded megagrazers only, reaffirming the strong effects these consumers can have on seagrass community composition and reinforcing their probable general importance to top down control of Australian tropical and subtropical seagrass ecosystems. Teleost grazers can also drive shifts in seagrass community composition; reef fish in south Florida (USA) preferentially consume the pioneer species Halodule wrightii, facilitating the dominance of the climax seagrass Thalassia testudinum (Armitage and Fourqurean 2006). In each of these cases, knowledge of seagrass life history traits, consumer feeding preferences, and grazing tactics are critical to determining which seagrass species dominate. Since pioneer seagrasses cannot generally match the ecosystem functions of climax species, these shifts in community composition can translate to important changes in the functions of seagrass beds.

\subsection{Effects of Consumers on Ecosystem Function}

As ecosystem engineers, seagrasses serve myriad ecological functions. Seagrasses influence processes such as nutrient cycling, sediment stabilization, and carbon storage (Orth et al. 2006, Fourqurean et al., 2012 and McLeod et al., 2011). 
Seagrasses also act as important habitat and nurseries for fauna (Heck et al. 2003). Many of these functions are much more pronounced in climax seagrasses than smaller, ephemeral species. The effects of top-down control on ecosystem function is dependent on the type and intensity of seagrass herbivory that occurs. For example, moderate levels of grazing by sea urchins grazing can stimulate nutrient recycling, while higher levels of grazing can remove seagrass beds almost entirely (e.g., Eklöf et al. 2008). In seagrass ecosystems in the Gulf of Mexico, sea urchins (Lytechinus variegatus) alter the aboveground biomass, shoot architecture, and seagrass density so much through their grazing that they appear to reduce the refuge capabilities of the seagrass beds and facilitate their own predators (Heck and Valentine 1995). Similarly, overgrazing by unusually high densities of L. variegatus in Florida Bay, USA resulted in losses of $>80 \%$ of seagrass biomass over more than 80 hectares, altering sediment structure and promoting resuspension of fine sediments (Rose et al. 1999). Such functional alterations can increase light attenuation, reduce the resilience of seagrass beds and promote shifts to alternate, seagrass depauperate states (Orth et al. 2006, Van der Heide et al. 2007, 2011). The associated loss of function from overgrazing can not only affect seagrass habitats, but also nearby habitats which depend on the ecosystem services seagrass ecosystems provide. In fact, loss of seagrass ecosystem function has implications on local to global scales. For example, seagrass loss can affect local faunal communities within and beneath seagrass beds (Heck et al. 2003, Rose et al. 1999, Thompson et al. 2014, Nowicki unpublished data), but also alters the amount of carbon sequestered in seagrass tissues and stored in sediments, influencing the role of seagrass ecosystems in the global carbon cycle (Fourqurean et al. 2012). Even apex predators can influence seagrass 
ecosystem function, through the trophic cascades they generate. Indeed, seagrass loss through overgrazing and extreme bioturbation have been linked (at least partially) to predator removal in these ecosystems, with implications for carbon sequestration and other functions (Heithaus et al. 2014, Atwood et al. 2015).

\subsection{Effects of Consumers on Bottom up Processes}

The previous example shows how top-down control can alter seagrass ecosystem function indirectly by altering bottom-up processes like sediment stabilization. However, consumers can also alter bottom-up processes directly- a form of top-down control rarely emphasized. Seagrass-associated fauna can do this by acting as nutrient subsidies, altering environmental variables, or changing chemical properties of seagrass ecosystems. For example, avian predators that hunt far from seagrass beds but rest above or adjacent to them can generate nutrient subsidies by transporting nutrient rich guano and concentrating into these habitats, stimulating seagrass productivity and changing seagrass community composition (Powell et al. 1991, Fourqurean et al. 1995). Similarly, the defecation and excretion of fish that seek shelter on coral reefs also provide a nutrient subsidy to nearby seagrass meadows (Dewsbury and Fourqurean 2010, Allgeier et al 2013). On a larger scale, sea lions (Neophoca cinerea) and fur seals (Arctocephalus spp.) native to temperate Australian waters deposit nutrients near their haul out sites through excretion. In Seal Bay Conservation Park, Kangaroo Island, South Australia, such defecation by the resident population of $\sim 1100$ sea lions contributes approximately 3800 $\mathrm{kg}$ of nitrogen to the surrounding ecosystem annually (Lavery et al. 2014.) This represents a considerable allochthonous source of nutrients which links pelagic 
productivity to coastal ecosystems, and is likely to be important to the structuring of seagrass ecosystems near pinniped colonies. Sharks may also play a role as nutrient transporters not only by coupling seagrass ecosystems with offshore pelagic ecosystems, but also by linking distant coastal ecosystems. For example, tiger sharks (Galeocerdo cuvier) in Australia regularly move hundreds to thousands of kilometers, spending time in both coastal and pelagic zones (Heithaus et al. 2007, Holmes et al. 2014, Ferreira et al. 2015). It should be noted that consumers can, of course, also transport nutrients out of seagrass ecosystems and that the effects of top-down alterations to nutrient cycling ultimately depends on the underlying nutrient characteristics of the surrounding environment. For example, large nutrient subsidies from a local seal colony are likely to exacerbate the effects of nutrient pollution from nearby anthropogenic sources, while consumer driven nutrient export in oligotrophic seagrass ecosystems may intensify nutrient limitation in these habitats, and vice versa.

Consumers can increase nutrient availability to seagrass ecosystems even if they themselves are immobile. For example, sponges can also alter bottom-up processes by processing nutrients in the water column, increasing their bio-availability to seagrasses (Archer et al. 2015). Similarly, bivalves concentrate nutrients in seagrass beds by consuming pelagic plankton and excreting their waste under the canopy (Peterson and Heck 2001). In addition to concentrating nutrients in seagrass beds, bivalves alter bottom-up processes in seagrass beds by altering the chemical and physical environment. Sulfur-oxidizing bivalve-bacteria symbionts are associated with most seagrass species and have been shown to increase seagrass biomass production in the face of sulfide additions (van der Heide et al. 2012). This mutualism is important, because marine 
sediments are generally anoxic and seagrasses expend large amounts of energy to pump oxygen gained from photosynthesis into below-ground tissues to create an "oxic microshield," which protect below-ground tissues from chemically reduced toxins (Borum et al. 2006). This need for protective oxygen drives the high light requirements of seagrasses and makes them highly sensitive to disturbance- particularly to reductions in water quality (Borum et al. 2012). Interestingly, a trophic cascade influencing this process have been recorded whereby preferential consumption of the filter feeding bivalve Dosinia isocardia by the Red Knot (Calidris canutus) reduces competition for particulate organic matter (POM) with a second bivalve Loripes lucinalis. L. lucinalis derives energy from both filter feeding and through chemosynthetic bacterial symbionts. Predation on D. isocardia may reduce competition for POM and allow L. lucinalis to deemphasize chemosynthetic pathways of energy production, which may result in higher concentrations of toxic porewater sulfide (Van Gils et al. 2012). As can be seen, topdown control through the manipulation of bottom-up processes can be important in structuring the chemical, nutrient, and physical environment in which seagrasses live, with implications for the persistence of seagrass ecosystems.

\section{Top Down Control and Human Impacts}

Humans are altering ecosystems worldwide, and seagrass ecosystems are no exception. All told, there are five major threats to marine biodiversity, all of which occur in seagrass ecosystems: overexploitation, physical habitat modification, sediment and nutrient pollution, invasive species, and climate change (Norse 1993, Waycott et al. 2009). Herbivores can either attenuate or amplify the effects of anthropogenic 
disturbance, and indirect effects that predators generate can further complicate these relationships. Yet it remains critical to understand how top down control both affects and is affected by human alterations to seagrass ecosystems. I focus here on four of the most pervasive threats to seagrass ecosystems and how they are likely to interact with patterns of top-down control: nutrient pollution, overfishing of marine consumers, invasive species, and climate change.

\subsection{Nutrient Pollution and Top Down Control}

While top-down control can attenuate the effects of eutrophication on seagrass ecosystems, nutrient pollution can also influence the strength of top-down control by altering energy distribution in the food web, herbivore feeding patterns, and predator prey dynamics. Eutrophication can increase the strength of top down control either by increasing the actual amount of herbivores or herbivory in seagrass ecosystems, or by reducing the tolerance of seagrasses to such herbivory. For example, as phytoplankton and epiphyte loads increase in response to eutrophication, consumer food supply growsincreasing secondary production in seagrass meadows and energy availability to higher trophic levels. This can lead to increased top down control by herbivores (e.g., Moksnes et al. 2008), which is particularly likely when mesograzers dominate, because their generally short life histories allow for rapid population responses to increased primary production and a potential outpacing of predator control. Because mesograzers and filter feeders generally have a facultative relationship with seagrasses and are capable of consuming large amounts of phytoplankton or epiphytic biomass (e.g., Whalen et al. 2013), this increase in top down control is likely largely facultative. However, in systems 
where mutualistic mesograzers are rare and most herbivory occurs through larger grazers, eutrophication may still strengthen top down control of these systems even when changes to herbivore population and grazing intensity are minimal. This is because the increased epiphyte loads that generally accompany nutrient pollution increase stress to seagrasses and may reduce their tolerance to direct herbivory. Additionally, increases in secondary production may strengthen non-consumptive predator effects in systems with risk-averse prey and result in less herbivore pressure, as prey in a high energy state are more likely to respond to predation risk (Heithaus et al. 2007). Finally, eutrophication can alter top down control by altering nutrient content or palatability of seagrass and epiphytes. This in turn can influence where, what, and how much herbivores consume.

\subsection{Overexploitation of consumers}

The most visible effect humanity has on top down control in seagrass ecosystems is actually through removing "the top" of seagrass food webs. Over the past few hundred years, both predators and herbivores have been lost from many coastal ecosystems (Jackson 2001, McCauley et al. 2015). These depletions, which usually target largebodied consumers like green turtles, sirenians, and large sharks, can eventually lead to depletion of smaller, lower trophic level consumers as old stocks collapse and new target species are harvested (ie. Pauly et al. 1998). Both depletion of herbivores and predators have important implications for the structure and function of seagrass ecosystems. Green turtles (Chelonia mydas) and dugongs (Dugong dugon) have both been subjected to substantial anthropogenic impacts throughout much of their ranges and population sizes are unlikely to approach what they were historically. Industrialized overfishing has 
also resulted in global population collapse of apex marine predators like large teleosts and sharks, which are disproportionately vulnerable to fishing (Jackson et al. 2001, Myers and Worm 2003, Ferretti et al. 2010). This is of particular concern because of the potential for irreversible losses of apex predator species, as has occurred in earth's terrestrial biomes. The loss of predators large and small alters food web dynamics and can affect herbivore guilds from large bodied megagrazers (Heithaus et al. 2008b, Heithaus et al. 2014) to amphipod mesograzers (Moksnes et al. 2008) and may alter not only patterns of predation but also reduce important risk effects (e.g., Madin et al. 2015). Shifts in the food web, including species diversity, can also generate or influence trophic cascades that change the strength and direction of top-down control of coastal ecosystems (Jackson 2001, Duffy 2005), leading to overgrazing, increased bioturbation, or plant loss with implications for ecosystem functioning (Atwood et al. 2015). For example, some argue that the ability of mesograzers to facilitate seagrass persistence by consuming harmful epiphytes may been weakened through the loss of apex marine predators, as mesopredators are released from predation and exert further pressure on epiphyte consumers (Williams and Heck 2001), though a trophic cascade may not occur if the mesopredators themselves are omnivores (Heck et al. 2000). Current predator removal studies generally focus on the effects of one or two species interactions, though predator removal often has cascading effects through multiple pathways simultaneously (Fig. 5).

The worldwide plight of shark populations has received considerable attention recently, with population declines estimated to exceed $80-90 \%$ in numerous locations (e.g., Baum et al. 2003, Myers et al. 2007, Dulvy et al. 2014, Worm et al. 2013). Although less appreciated, many populations of rays also are threatened (Dulvy et al. 
2014), and the potential for rays to generate trophic cascades down the filter feeder pathway remains untested. These declines in elasmobranch populations have the potential to modify seagrass ecosystems through multiple mechanisms. Surprisingly, despite the ubiquity of marine apex predator declines and the potential for important consequences to these declines, few studies of the effects of such declines in seagrass ecosystems exist (however see Heithaus et al. 2012 and references therein).

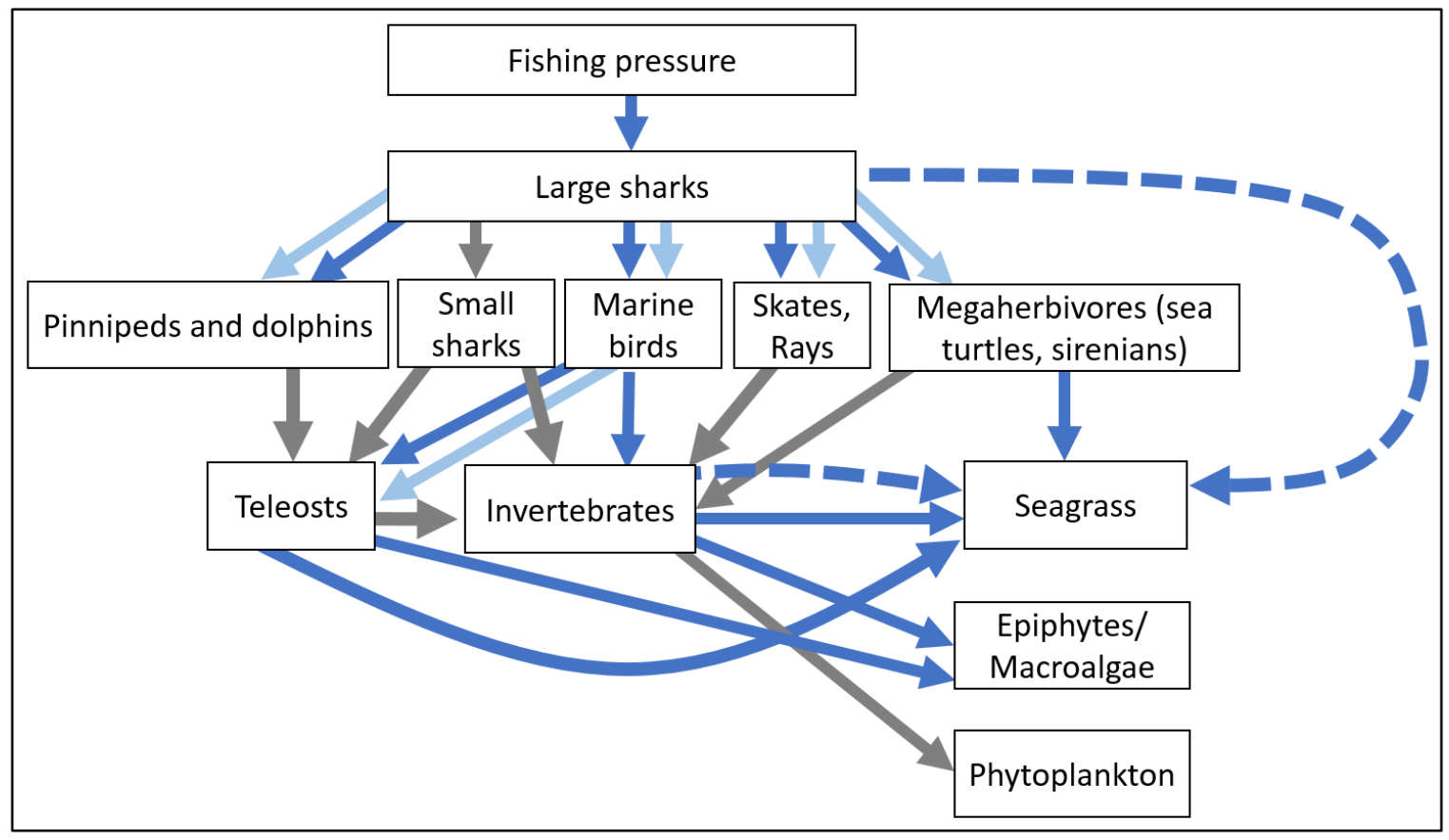

Figure 5. Interaction web highlighting potential connections between large shark removal and lower trophic levels based on current quantitave research. Dark and light arrows indicate direct predation and risk effects, respectively; dotted lines indicate indirect effects. Interactions which have been observed in Australian seagrass ecosystems are shaded blue. Note the effects teleosts and invertebrates on seagrasses, as well as estimates of indirect effects in Australian systems, are lacking. Modified from Ferretti et al. 2010.

\subsection{Invasive Species}

Seagrasses themselves can be invasive species, though records of this occurring are rare. Successful introductions are exemplified by the recent expansions of two small- 
bodied, fast-growing seagrasses: Zostera japonica along the eastern Pacific Ocean (Mach et al 2014) and Halophila stipulacea in the Caribbean Sea (Willette et al 2014). Both of these species have weed-like life history characteristics, including high rates of sexual reproduction and seed set and rapid growth rates that predispose them to be successful invaders. While the documentation of invasive populations of seagrasses into the eastern Pacific and Caribbean is recent, it may be that humans have been spreading palatable, weedy seagrasses around the globe for centuries. Phillips and Menez (1988) have suggested that the weedy, fast-growing species Halophila decipiens, widely distributed in harbours across the tropical parts of the Atlantic, Pacific and Indian Oceans as well as some extra-topical locales such as Sydney Harbour, could have been spread by shipping activity. Similarly, Halophila stipulacea, originally native to the Red Sea and western Indian Ocean, is proposed to have spread to the Mediterranean sea over a century ago with the opening of the Suez canal before spreading to the Caribbean (Lipkin 1975, Willette et al. 2014). As fast-growing seagrasses are preferred as food over more slowgrowing ones, and since the species that natural occur in the regions being colonized by these invaders have slower growth, top-down control by seagrass herbivores may prove to be important in regulating the biomass of these invaders.

Most invasive species in seagrass ecosystems are not seagrass, but algae and fauna (Williams 2007). These invasive species usually generate negative effects in the seagrass ecosystems to which they are introduced (Williams 2007). For example, in San Francisco Bay, USA, the invasive amphipod Amphithoe valida consumes Zostrea. marina tissues directly in its invaded range (Northeastern Pacific), but rarely consumes $Z$. marina in its native range (the north-west Atlantic) (Reynolds et al. 2012). Additionally, 
teleost predators in A. valida's invaded range are less effective at controlling its population than predators in its natural range (Carr and Boyer 2014). This highlights not only the importance of understanding herbivore feeding preferences, but also the difficulty in using the ecology of invasive species in their native ranges to predict their effects in their invaded ranges.

Invasive species are likely to become more common in seagrass ecosystems with time, as widespread changes in species distributions occur through both traditional human means (i.e., intentional introduction and hitch-hiking on human transport) and through climate change induced range shifts. These range shifts will be largely poleward and may occur gradually (over decades) or rapidly (over months) (Parmesan and Yohe 2003, Fodrie et al. 2009, Last et al. 2011, Poloczanska et al. 2013, Wernberg et al. 2013, Wernberg et al. 2011, Smale and Wernberg 2013, Vergés et al. 2014). Such shifts have the potential to completely re-arrange communities as species migrate at differing rates. The resulting decoupling of some species-species interactions and the formation of novel ones (Walther et al. 2002, Cheung et al. 2009, Kordas et al. 2011) has the potential to alter the strength of top down control in seagrass ecosystems and to destabilize those ecosystems (Vergés et al. 2014). For example, the herbivorous sea urchin Centrostephanus rodgersii has shifted poleward along Australia's southeastern coast by more than $600 \mathrm{~km}$ in four decades, resulting in its establishment in Tasmanian waters and a concomitant increase in the prevalence of urchin barrens there; exclosure experiments suggest that $C$. rodgersii is responsible for such barrens, and that community diversity at these sites is reduced by $~ 70 \%$ compared to intact kelp beds (Ling 2008). In the subtropical seagrass habitats of the northern Gulf of Mexico, the tropical herbivorous 
teleost Nicholsina usta has increased in abundance almost 25 fold, and is predicted to reduce seagrass cover as warming continues (Heck et al. 2014). Novel associations between herbivores and predators may also alter the direction of effect of top down control. Despite the global scale at which this community mixing is predicted to occur, we have a poor understand of how new species introductions influence seagrass ecosystems, with the effects of most invasive species unassessed (Williams 2007).

The potential for novel species assemblages to completely restructure benthic marine communities is probably not uniform. Seagrasses in temperate ecosystems are likely more vulnerable than those in tropical and subtropical ecosystems to reorganization of the consumer community. This is because of the higher niche diversity of the tropics, which increases the potential for consumers to exploit previously unoccuPiedniches in temperate systems (Bennett et al. 2015). Furthermore, tropical seagrass ecosystems will experience fewer introductions via range shifts, since temperature induced range shifts are generally poleward. Conversely, temperate seagrass ecosystems may show recalcitrance to range expansions of tropical seagrasses. Indeed, higher latitudes would reduce available light to tropical species, resulting in both reduced growth rates and potentially increased nutrient content and palatability (Fourqurean et al. 2015). In this sense, range shifts may increase the strength of top down control in temperate seagrass habitats, but via different mechanisms for temperate and tropical seagrasses. Australian seagrass ecosystems will be particularly vulnerable to disruptive distribution shifts as Australia is the only continent to have poleward-flowing boundary currents on both coasts, and because its southern coastline occupies only a narrow latitudinal bandmeaning changes in ocean temperatures will have very widespread effects on temperate 
Australian ecosystems (Wernberg et al. 2011b). This poises Australian seagrass ecosystems on the front lines of climate change and provides both a conservation challenge and an opportunity to study how climate change driven species invasions will alter seagrass ecosystems worldwide.

\subsection{Climate Change}

Climate change is probably the single largest avenue through which humans are altering the marine environment. Most effects of climate change are ultimately due to physical forcing of the environment. However, there is increasing evidence that the ecological effects of climate change will be mediated by biotic interactions (Zarnetske et

al. 2012). Beyond altering species distributions, climate change will affect the strength of top down control by altering the metabolism, production and consumption rates of organisms, changing stoichiometric ratios of producers, and amplifying climactic extremes, which may reduce the resilience of seagrass ecosystems to herbivory or other means of top-down control. Understanding how these complex interactions will shape seagrass communities is paramount to the management and conservation of these ecosystems in the era of climate change.

As temperature increases, so do the rates of biological processes of ectotherms such as metabolism and consumption (Hillebrand et al. 2009, O'Connor 2009). This ability of temperature to influence metabolic processes and structure ecosystems is the emphasis of the Metabolic Theory of Ecology, or MTE (Brown et al. 2004). Because changes in temperature have the potential to profoundly alter consumption rates, production rates, and the effects consumers have on their ecosystems, MTE has received 
an explosive surge in attention in the past decade. Since the overwhelming majority of species in seagrass ecosystems are poikilotherms, such changes in temperature can affect entire communities, though different species are likely to react differently. This is because the relationship between metabolic rate and temperature follows a unimodal pattern that peaks at a species-specific thermal optimum, after which physiological stress weakens the relationship, eventually reducing an organism's fitness (Lemoine and Burkepile 2012). Indeed, a central question in MTE is that of metabolic mismatches: what happens when the metabolisms of different organisms scale differently as temperatures rise? Such differential metabolic scaling can have significant ecological consequences for seagrass ecosystems.

The effects of temperature increases on the strength of top-down control will depend largely on how the metabolisms of producers, herbivores, and predators change in relation to one another. For example, if herbivore consumption rates increase faster than primary producer production rates, then top-down control on plant communities is likely to strengthen. Conversely, increases in predator consumption rates or hunting efficiency may increase top-down control on herbivores, releasing resource species from consumption. Furthermore, rates of primary productivity may outstrip the ability of consumers to regulate it, resulting in a weakening of top-down control. Finally, if temperatures surpass the thermal optimum of a species, fitness may suffer, reducing the interaction strength of a consumer with its prey.

Though the topic of differential metabolic scaling in relation to climate change remains fairly young, multiple examples detailing the effects of simulated or real warming on the strength of top-down control in seagrass ecosystems exist. For example, 
experimental warming of mesocosms containing amphipod grazers and benthic brown algae Sargassum filipendula showed that a $4^{\circ} \mathrm{C}$ temperature increase resulted in stronger, more negative per-capita interaction strength between the amphipods and algae, indicating stronger consumer control (O’Connor 2009). Similarly, in mesocosms in the Galapagos Islands, green sea urchins (Lytechinus semituberculatus) exposed to multi-day warming $\left(28^{\circ} \mathrm{C}\right)$ doubled their oxygen consumption increased their consumption of the green algae Ulva sp. by almost 50\% compared to urchins kept at cooler temperatures $\left(14^{\circ} \mathrm{C}\right)($ Carr and Bruno 2013). In South Australia, when the sea urchin Amblypneustes pallidus was placed in microcosms mimicking $5^{\circ} \mathrm{C}$ of ocean warming and an increase in $\mathrm{CO}^{2}$ concentrations expected to occur by 2100 , urchins increased consumption rates of the Australian endemic seagrass Amphibolis antarctica by 20\% (Burnell et al. 2013b). In a predator prey study, experimental warming of a terrestrial old field ecosystem resulted in reduced spatial overlap of spider predators and grasshopper nymph prey, which in turn reduced predator control of herbivores (Barton 2010). In these studies, increases in top-down control were driven primarily by shifts in per-capita effects rather than in consumer densities. This emphasizes the capability of climate change, through physical forcing, to alter the effects of individual consumers on a global scale with potentially significant changes to the strength of top down control at the most basic physiological level.

Climate change may also weaken the potential strength of top-down control by increasing primary productivity. In some cases, this productivity increase can even outpace increased consumption rates of herbivores. For example, experiments in South Australian rocky coastal ecosystems showed that under moderate warming (to $20^{\circ} \mathrm{C}$ ), the 
marine gastropod Turbo undulates can maintain consumption rates that outpace turf algae production; under conditions predicted by $2100\left(24^{\circ} \mathrm{C}\right)$, however, turf algae production outpaced consumption (Mertens et al. 2015). This phenomenon is particularly likely to occur when dominant consumers surpass their thermal optimum and undergo temperature-related physiological stress, reducing their "efficiency" (e.g., Lemoine and Burkepile 2012, Strong 1992), or when grazer control of primary producers is already weak (O'Connor et al. 2009, Elköf et al. 2012). While compensatory herbivore population growth may dampen runaway productivity effects as consumer populations adjust to reflect the increased food supply, even a temporary loss of consumer control could lead to algal overgrowth of seagrass and increase the likelihood of a regime shift to a seagrass depauperate state, as we will see shortly. Understanding how herbivory, production, predation, and other biological interactions will scale with increases in temperature is critical since seagrass ecosystems are dominated by ectotherms whose metabolism is inherently coupled to ambient temperatures.

While temperature will alter top-down control of consumers, increased $\mathrm{CO}_{2}$ concentrations are predicted to increase seagrass production, since seagrasses are often light and $\mathrm{CO}_{2}$ - limited (Borum et al. 2015). However, increased production is often paired with reduced proportions of nitrogen and phosphorous in seagrass tissues, reducing their quality as a food source. For example, six-month $\mathrm{CO}_{2}$ enrichment experiments in South Florida, USA, designed to replicate atmospheric $\mathrm{CO}_{2}$ concentrations in 2100, increased non-structural carbohydrate content of Thalassia testudinum rhizomes by $29 \%$ but also reduced nitrogen and phosphorous content of leaves by $11 \%$ and 21\%, respectively (Campbell and Fourqurean 2013). Differences in 
stoichiometry may increase herbivore consumption rates to compensate for this lower food quality, or may cause herbivores to avoid lower quality plants and switch to plants of higher food quality (Cruz-Rivera and Hay 2001, Valentine and Heck 2001, Russell and Connel 2007, Hillebrand et al. 2009, Tomas et al. 2011). Changes in temperature and ocean chemistry may also alter plant defensive compounds and secondary metabolites. Since consumer preference is driven by a combination of factors which includes plant defensive compounds (e.g., Steele and Valentine 2015), determining whether (and if so, how) $\mathrm{CO}_{2}$ concentrations affect plant defenses will also be a key part in understanding the shifting role of herbivores in top-down control. Multi-species $\mathrm{CO}_{2}$ enrichment experiments should also be undertaken to determine the potential for $\mathrm{CO}_{2}$ enrichment to majorly alter nutrient concentration hierarchies. These experiments should be paired with simultaneous food choice experiments exploring the potential for this to change consumer preferences or herbivory rates. These investigations would be particularly fruitful for Australia's subtropical ecosystems where species and life history diversity of seagrass is highest.

In addition to range shifts, extreme climactic events can alter seagrass communities and potentially increase the ability of top-down control to generate alternate, seagrass-depauperate ecosystem states. Seagrasses ecosystems are vulnerable to regime shifts, whereby the ecosystem tolerates disturbances to a point before rapidly shifting to an alternate ecosystem state that is often resistant to change. Indeed, environmental stress can increase the vulnerability of seagrass to grazing (e.g., Elköf et al. 2010), potentially resulting in top-down control exacerbating the effects of disturbances after they occur. Regime shifts, initiated by climactic disturbance and 
reinforced by herbivore control, have already been recorded in Australian marine ecosystems. On temperate algae reefs in Port Gregory, Western Australia, the loss of the algae canopy associated with a marine heat wave (Pearce and Feng 2013) was reinforced by algivorous teleosts, largely tropical in origin (Bennet et al. 2015). This resulted in shift from an ecosystem state dominated by complex canopy forming algae to one of structurally simple turf algae, which was reinforced by constant herbivory on any remaining kelp (Bennet et al. 2015). Shark Bay's seagrass beds, which were subjected to the same marine heat wave (Thompson et al. 2014, Fraser et al. 2014), may be buffered from similar effects as healthy populations of tiger sharks generate antipredator responses in dugongs, minimizing herbivore control of disturbed seagrass beds (Nowicki et al. unpublished data). Australian seagrass ecosystems are particularly susceptible to these interactive effects of climate disturbance and herbivory because both East and West coasts are home to tropical boundary currents that force tropical waters poleward- and while our oceans are expected to warm globally, these "hotspots" are projected to do so 2-3 times faster than average (Wu et al. 2012, Vergés et al. 2014). Furthermore, these currents are capable of generating rapid and extreme warming events (e.g., Pearce and Feng 2013) such as the aforementioned marine heat wave that struck Western Australia in 2011 and caused widespread ecological changes throughout the coast (Wernberg et al. 2013, Smale and Wernberg 2013, Thompson et al. 2014, Fraser et al. 2014). These examples indicate the potential for climactic disturbance and other anthropogenic stressors to interact to alter the role of top-down control in benthic marine ecosystems and highlight the need for a better understanding of how climate change will interact with anthropogenic stressors at regional and local scales (Wernberg et al. 2011). 
As our understanding of individual species relationships under climate change becomes clear, it will be necessary to put them in the context of larger, community scale interaction webs if we are ever to elucidate how top down control will change in our warming oceans. Furthermore, we need to consider the potential for temperature induced metabolism shifts to interact with other ecosystem properties to attenuate or magnify the strength of top-down control, especially since few seagrass ecosystems are subject to isolated anthropogenic impacts. For example, nutrient enrichment of producers can result in increased satiation and decreased per capita grazing sea urchins (Valentine and Heck 2001), suggesting that nutrient enrichment may attenuate some effects of temperature induced increases in consumption rates (Burnell et al. 2013b).

\section{Conclusions and Future Directions}

\subsection{Progress in the past quarter century}

Twenty five years ago, top down control of seagrass ecosystems was given limited attention focusing on the role of grazing by sea turtles and dugongs, and to a lesser degree, teleosts. This emphasis illustrates an important and relatively unique aspect of Australian seagrass ecosystems: many still have ecologically functional populations of megaherbivores and apex predators, particularly in the tropics and subtropics. However, in the past several decades, our view of top-down control in seagrass ecosystems has changed dramatically. Thanks to advances in theory as well as an increasing number of laboratory, mesocosm, and field experiments around the world over the past quarter century, there has been a shift from descriptive studies (Duarte 1999) to a more process oriented approach in seagrass ecology. This shift has led to a 
much better understanding of how mesograzers, predators, and food web structure interact with each other and with bottom-up factors to structure seagrass ecosystems. We also better understand how human impacts, particularly eutrophication (Hughes et al. 2004) and apex predator removal (Heithaus et al. 2008, Burkholder et al. 2013) are likely to influence seagrass ecosystems. New promising field approaches developed in Australian seagrass habitats, such as cage-less mesograzer exclusions (Poore et al. 2009) and long term multi-trophic level ecosystem research projects (sensu Heithaus et al. 2012), have already provided critical insight into top-down control of these seagrass ecosystems and will enable further refinement of our understanding of top down control of seagrass habitats worldwide.

\subsection{Gaps that Still Remain}

Despite the progress made in characterizing top down control in seagrass ecosystems over the last quarter century, many gaps still remain. In particular, the complexity with which top-down control operates in seagrass ecosystems creates new challenges to generalizing top-down control (Valentine and Duffy 2006). I begin with a call to expand the use of manipulative field experiments in Australian seagrass habitats. This approach is among the most effective in determining how individual or groups of species influence seagrass ecosystems, and when paired with mechanistic studies can

provide powerful insight into how top down control operates in these ecosystems. This is particularly true for the dominant and widespread endemic seagrasses in the genera Posidonia and Amphibolis. Though they are becoming more common, exclosure and enclosure experiments remain under-used in testing theory related to top down control, 
and these experiments remain rare in Australian seagrass habitats when compared to other geographic regions and types of benthic marine ecosystems. For example, out of over 600 herbivore exclusion experiments analyzed by Poore et al. (2012), only 28 studies occurred in seagrass beds, with only 4 of those occurring in Australia (though there have since been others, see Figure 6). All of these studies have occurred in temperate or subtropical seagrass ecosystems. This is probably largely due to the huge logistical challenges associated with completing marine research in these sparsely populated areas. Nonetheless, I believe tropical Australian seagrass ecosystems are understudied and warrant further attention, particularly as seagrass diversity in tropical Australia is high, and our understanding of herbivory in multi-species seagrass beds is still relatively lacking (Lee et al. 2015). Indeed, northern Australia is home to a diverse and expansive tropical seagrass community as well as large populations of macro- and megaherbivores, suggesting herbivory may be an important structuring force in tropical Australian seagrass beds (e.g., Marsh and Lawler 2000, Marsh et al. 2002, Roelofs et al. 2005, Andre et al. 2005, Sheppard et al. 2008). This is supported by limited evidence from aerial surveys, which indicate that seagrass beds in parts of the Northern Territory and northern Queensland are often heavily scarred from dugong grazing (Roelofs et al. 2005).

As has been emphasized throughout this chapter, understanding herbivore feeding preferences is critical to predicting the nature of top-down control in seagrass ecosystems. A large body of research has investigated relationships between food quality, plant defenses, seagrass structure, and the effects of associated producers, yet these experiments necessarily simplify the number of variables tested because of 


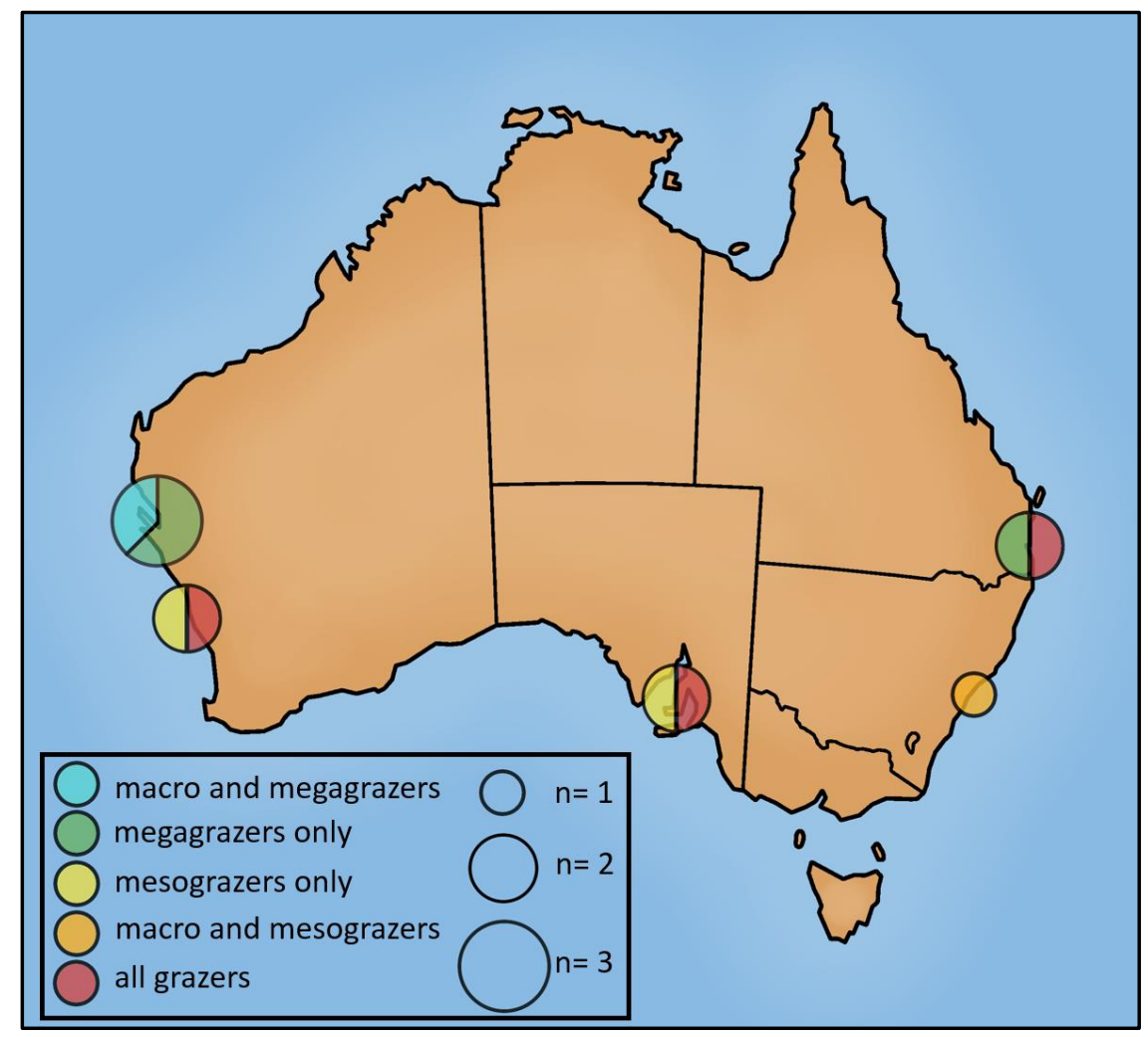

Figure 6. Sites of herbivore exclosure field experiments in Australian seagrass ecosystems (Total= 10 studies, some of which include multiple experiments). Yellow studies achieved herbivore exclusion through in-situ chemical pesticide deployments; other studies used physical cages. Note a complete lack of exclosure studies in tropical Australian ecosystems. Red studies: Jernakoff and Nielsen 1997, Keuskamp 2004, Ebrahim et al. 2014; orange: Garthwin et al. 2014; yellow: Cook et al. 2011, McSkimming et al. 2015; green: Preen 1995, Masini 2001, Burkholder et al. 2013; teal: Bessey et al. 2016. Ebrahim et al. 2014 performed multiple experiments using both cages and pesticides that varied in level of exclusion, from megaherbivore exclusion only to total herbivore exclusion.

experimental constraints. We still lack a generalizable mechanistic understanding of how seagrass properties as a whole influence food preferences or consumption rates by herbivores. Instead, we are limited to rough generalizations (such as the previously discussed dichotomy in herbivore feeding preference), which are based on larger patterns from food preference experiments. The relationship between seagrass properties and herbivore feeding behavior is confounded by seagrass properties including palatability 
(high nutrient, soluble carbohydrate, and lipid content), undesirable traits (defensive phenolic compounds, low nutrient content, and high fiber content), and seagrass structure, which can vary among and within species as well as through space and time. This relationship is further obscured by the variable efficacy of phenolic defenses on different herbivores and the differential perceived value of each of these seagrass properties by different herbivores (e.g., Goecker et al. 2005, Prado and Heck 2011). Because of this it is still difficult to generalize how herbivory influences seagrass community response to anthropogenic stressors like eutrophication and $\mathrm{CO}_{2}$ enrichment, or how pressures on herbivores (such as predation risk) may alter patterns of top-down control. Given the ubiquity of these stressors and the knowledge that they can interact (e.g., Burnell et al. 2013b), pursuit of a predictive model of how this may occur warrants serious attention. Meta-analyses would be useful to determine how patterns of seagrass nutrient concentration, phenolic compounds, carbohydrate content and other characteristics relate to seagrass consumption rates of different herbivores.

Over the past two decades it has become increasingly apparent that grouping consumers into ecological guilds based on taxonomy or size over-simplifies the diversity of their ecological functions (Duffy et al. 2001, 2003, Valentine and Duffy 2006). This is most true for mesograzers. For example, selective herbivore exclusion experiments in Moreton Bay, Queensland, showed that exclusion of small amphipod mesograzers resulted in a more than doubling of epiphyte biomass while exclusion of larger invertebrate mesograzers resulted in increases in seagrass shoot height, density, and cover (Ebrahim et al. 2014). A similar experiment showed that some mesograzers control epiphyte loads while others do not (Jernakoff and Nielsen 1997). Clearly, these 
organisms have distinct functional roles in top down control yet are generally grouped simply as "mesograzers." This has been recognized as an oversimplification as ecosystem level impacts are the result of complimentary effects from a diverse range of grazers- not from a single homogenous effect by a uniform herbivore guild (Duffy et al. 2001, 2003, Hughes et al. 2004, Burkepile and Hay 2008, Holzer et al. 2011, Rossini et al. 2014). Yet gaps remain in our understanding of the complimentary roles of sympatric herbivores or the relative strength with which they can exert top-down control (but see Holzer et al. 2011)- often limiting our ability to estimate the net effects of groups of herbivores or herbivores as a whole on seagrass communities. This is an important omission- particularly in regards to differences in interaction strength between major grazer groups and seagrass-because megagrazers, macrograzers and mesograzers are often managed very differently (if at all). Additionally, the effects different grazer groups can generate in seagrass ecosystems can be surprising; for example, herbivores can generate opposite responses in seagrass communities even when they consume the same species of seagrass. Dugongs can facilitate the same seagrass species they target when grazing through destructive and indiscriminant feeding tactics which also remove competitively dominant climax seagrass (Preen 1995). Invertebrate and teleost herbivores, however, are more selective and instead usually suppress the species they target.

Finally, our understanding of how top-down control of seagrass ecosystems will change in the context of human stressors like overfishing and climate change is still in its infancy. Indeed, while there is an increasing focus on how trophic interactions will change as climate change variables continue, few of these studies are in marine 
ecosystems (Rosenblatt and Schmitz 2014). Furthermore, most of these studies fail to capture the complexity climate change will bring to trophic interactions- often only manipulating two trophic levels and one climate change variable at a time (Rosenblatt and Schmitz 2014). Understanding how climate change, overfishing and other human impacts will alter top down control of seagrass ecosystems will require increasing both the complexity of existing experiments to better understand interactions, and rigorous syntheses of existing experiments to discover general patterns between these factors.

\subsection{Maximizing Research Potential in Australian Seagrass Habitats}

One problem of studying top-down control in coastal ecosystems (including seagrass ecosystems) is that today's seagrass communities have often been fundamentally altered from the conditions under which the ecosystems evolved (Heck and Valentine 2007, Jackson 2001, Dayton et al. 1995). As a result, studies (particularly of predators) in today's seagrass ecosystems probably don't accurately capture the historical importance of top down control. Indeed, while we have a solid understanding of the mechanisms through which trophic cascades can operate, determining the net effects of predator loss on seagrass ecosystems remains difficult because trophic cascades can operate through multiple consumer pathways concurrently (Fig. 4) and the relative strength of these pathways remains largely unknown. Many of Australia's seagrass ecosystems, particularly those in the tropical northern and western coasts, remain far from large population centers and provide unique opportunities to study top-down control in relatively pristine seagrass ecosystems. Yet, few of these studies exist. By pursuing the effects of megafauna and apex predators in seagrass ecosystems, focusing on 
relatively pristine seagrass ecosystems where biodiversity and trophic relationships remain relatively intact, and establishing long-term monitoring projects along the eastern and western coasts where tropical boundary currents will generate "sentinel" ecosystems, in which to study climate change, researchers can leverage the natural capital of Australia's seagrass habitats in ways few other regions can. A better understanding of how predators and megaherbivores structure seagrass ecosystems will become increasingly relevant as populations of megaherbivores like green turtles are restored in regions where they were formally abundant (Heithaus et al. 2014).

The ultimate goal of understanding top down control in seagrass ecosystems is to create a testable framework through which we can make generalizations and predict how top down control will impact those ecosystems. For such a framework to be useful it will have to incorporate theoretical advances as well as a huge compliment of field, laboratory, and observational work to test, validate, and refine it. It will also have to incorporate the role of physical factors (such as temperature and nutrient regimes), species traits (such as species identity and food preferences) and trophic structure (competitive, facilitative, and predator prey relationships) and larger community properties (such as biological and functional diversity). Finally, it will involve understanding the processes that drive the patterns we observe. This is an enormous challenge, but one that will be necessary if we are to effectively generalize patterns we observe in a select few seagrass ecosystems to the many that will need to be managed in the future. 


\section{Final Thoughts}

A wide body of work over the past few decades has shown that top-down control can be an important (and even dominant) structuring force in seagrass ecosystems. However, the complexity of these interacting ecosystems continues to make broad generalizations about top-down control difficult. Many Australian seagrass ecosystems have unique qualities, driven by seagrass or megafaunal assemblages not widely found elsewhere. General ecological theory, derived from studied worldwide, will continue to provide hypothesis to test the role of top-down control in seagrass- but an understanding of top-down control in Australian seagrass ecosystems will ultimately have to come from work inside Australia. We have learned much since the original realization of the importance of top-down control in seagrass ecosystems. The challenge now is to understand when top-down control is important in seagrass ecosystems, what factors control its strength and effects on the seagrass community, where feedbacks or interactions between factors are likely to occur, and what impacts anthropogenic alterations to the local and global environment will have on top-down control. Further research into these areas will aid pursuit of the end goal of a general integrative framework of top-down control in seagrass ecosystems.

Acknowledgements: I would like to thank the editors for their invitation to write this chapter, and R. Sarabia for comments on an early copy of the manuscript. Financial support for RJN was provided by Florida International University and by NSF GRF No. DGE-1038321. This is contribution number 81 from the Shark Bay Ecosystem Research Project (SBERP) and contribution number 12 from the Marine Education and Research 
Center (MERC) in the Institute for Water and the Environment at Florida International

University.

Literature Cited

Agostini, S., Desjobert, J.-M., and Pergent, G. (1998). Distribution of phenolic compounds in the seagrass Posidonia oceanica. Phytochemistry 48, 611-617.

Alcoverro, T., Duarte, C.M., and Romero, J. (1997). The influence of herbivores on Posidonia oceanica epiphytes. Aquatic Botany 56, 93-104.

Allgeier, J.E., Yeager, L.A., and Layman, C.A. (2013). Consumers regulate nutrient limitation regimes and primary production in seagrass ecosystems. Ecology 94, 521-529.

Anderson, P.K. (1986). Dugongs of Shark Bay, Australia-Seasonal migration, water temperature, and forage. Natl. Geogr. Res. 2, 473-490.

Aragones, L., and Marsh, H. (2000). Impact of dugong grazing and turtle cropping on tropical seagrass communities. Pacific Conservation Biology 5, 277-288.

Archer, S.K., Stoner, E.W., and Layman, C.A. (2015). A complex interaction between a sponge (Halichondria melanadocia) and a seagrass (Thalassia testudinum) in a subtropical coastal ecosystem. Journal of Experimental Marine Biology and Ecology 465, 33-40.

Armitage, A.R., and Fourqurean, J.W. (2006). The short-term influence of herbivory near patch reefs varies between seagrass species. Journal of Experimental Marine Biology and Ecology 339, 65-74.

Atwood, T.B., Connolly, R.M., Ritchie, E.G., Lovelock, C.E., Heithaus, M.R., Hays, G.C., Fourqurean, J.W., and Macreadie, P.I. (2015). Predators help protect carbon stocks in blue carbon ecosystems. Nature Climate Change 5, 1038-1045.

Barton, B.T. (2010). Climate warming and predation risk during herbivore ontogeny. Ecology 91, 2811-2818.

Baum, J.K., Myers, R.A., Kehler, D.G., Worm, B., Harley, S.J., and Doherty, P.A. (2003). Collapse and conservation of shark populations in the Northwest Atlantic. Science 299, 389-392. 
Belicka, L.L., Burkholder, D., Fourqurean, J.W., Heithaus, M.R., Macko, S.A., and Jaffé, R. (2012). Stable isotope and fatty acid biomarkers of seagrass, epiphytic, and algal organic matter to consumers in a pristine seagrass ecosystem. Marine and Freshwater Research 63, 1085-1097.

Bessey, C., and Heithaus, M.R. (2013). Alarm call production and temporal variation in predator encounter rates for a facultative teleost grazer in a relatively pristine seagrass ecosystem. Journal of Experimental Marine Biology and Ecology 449, $135-141$.

Bessey, C., and Heithaus, M.R. (2015). Ecological niche of an abundant teleost, Pelates octolineatus, in a subtropical seagrass ecosystem. Mar Ecol Prog Ser 541, 195204.

Bessey, C., Heithaus, M.R., Fourqurean, J.W., Gastrich, K.R. \& Burkholder, D.A. (2016). Importance of teleost macrograzers to seagrass composition in a subtropical ecosystem with abundant populations of megagrazers and predators. Marine Ecology Progress Series, 553, 81-92.

Blaber, S.J.M., and Wassenberg, T.J. (1989). Feeding ecology of the piscivorous birds Phalacrocorax varius, P. melanoleucos and Sterna bergii in Moreton Bay, Australia: diets and dependence on trawler discards. Mar. Biol. 101, 1-10.

Borer, E.T., Seabloom, E.W., Shurin, J.B., Anderson, K.E., Blanchette, C.A., Broitman, B., Cooper, S.D., and Halpern, B.S. (2005). What determines the strength of a trophic cascade? Ecology 86, 528-537.

Borum, J., Sand-Jensen, K., Binzer, T., Pedersen, O., and Greve, T.M. (2007). Oxygen Movement in Seagrasses. In Seagrasses: Biology, Ecology, and Conservation, (Springer Netherlands), pp. 255-270.

Borum, J., Gruber, R.K., and Kemp, W.M. (2012). Seagrass and Related Submersed Vascular Plants. Estuarine Ecology, Second Edition 111-127.

Borum, J., Pedersen, O., Kotula, L., Fraser, M.W., Statton, J., Colmer, T.D., and Kendrick, G.A. (2015). Photosynthetic response to globally increasing CO2 of co-occurring temperate seagrass species. Plant, Cell \& Environment.

Brand-Gardner, S.J., Limpus, C.J., and Lanyon, J.M. (1999). Diet selection by immature green turtles, Chelonia mydas, in subtropical Moreton Bay, south-east Queensland. Aust. J. Zool. 47, 181-191.

Brearley, A., and Walker, D.I. (1995). Isopod miners in the leaves of two Western Australian Posidonia species. Aquatic Botany 52, 163-181. 
Brearley, A., Kendrick, G.A., and Walker, D.I. (2008). How does burrowing by the isopod Limnoria agrostisa (Crustacea: Limnoriidae) affect the leaf canopy of the southern Australian seagrass Amphibolis griffithii? Mar Biol 156, 65-77.

Brodeur, M.C., Piehler, M.F., and Fodrie, F.J. (2015). Consumers mitigate heat stress and nutrient enrichment effects on eelgrass Zostera marina communities at its southern range limit. Mar Ecol Prog Ser 525, 53-64.

Brown, J.S., and Kotler, B.P. (2004). Hazardous duty pay and the foraging cost of predation. Ecology Letters 7, 999-1014.

Brown, J.H., Gillooly, J.F., Allen, A.P., Savage, V.M., and West, G.B. (2004). Toward a metabolic theory of ecology. Ecology 85, 1771-1789.

Brown, J.S., Laundré, J.W., and Gurung, M. (1999). The ecology of fear: optimal foraging, game theory, and trophic interactions. Journal of Mammalogy 80, 385399.

Burkholder, D.A., Heithaus, M.R., and Fourqurean, J.W. (2012). Feeding preferences of herbivores in a relatively pristine subtropical seagrass ecosystem. Marine and Freshwater Research 63, 1051-1058.

Burkholder, D.A., Heithaus, M.R., Fourqurean, J.W., Wirsing, A., and Dill, L.M. (2013). Patterns of top-down control in a seagrass ecosystem: could a roving apex predator induce a behaviour-mediated trophic cascade? Journal of Animal Ecology 82, 1192-1202.

Burnell, O.W., Connell, S.D., Irving, A.D., and Russell, B.D. (2013a). Asymmetric patterns of recovery in two habitat forming seagrass species following simulated overgrazing by urchins. Journal of Experimental Marine Biology and Ecology $448,114-120$.

Burnell, O.W., Russell, B.D., Irving, A.D., and Connell, S.D. (2013b). Eutrophication offsets increased sea urchin grazing on seagrass caused by ocean warming and acidification. Marine Ecology. Progress Series 485, 37-46.

Campbell, J.E., and Fourqurean, J.W. (2013). Effects of in situ $\mathrm{CO}^{2}$ enrichment on the structural and chemical characteristics of the seagrass Thalassia testudinum. Marine Biology 160, 1465-1475.

Carr, L.A., and Boyer, K.E. (2014). Variation at multiple trophic levels mediates a novel seagrass-grazer interaction. Mar. Ecol. Progr 508, 117-128.

Carr, L.A., and Bruno, J.F. (2013). Warming increases the top-down effects and metabolism of a subtidal herbivore. PeerJ 1, e109. 
Cebrián, J., and Duarte, C.M. (1998). Patterns in leaf herbivory on seagrasses. Aquatic Botany 60, 67-82.

Cebrián, J., Duarte, C.M., R. Agawin, N.S., and Merino, M. (1998). Leaf growth response to simulated herbivory: a comparison among seagrass species. Journal of Experimental Marine Biology and Ecology 220, 67-81.

Cheung, W.W., Lam, V.W., Sarmiento, J.L., Kearney, K., Watson, R., and Pauly, D. (2009). Projecting global marine biodiversity impacts under climate change scenarios. Fish and Fisheries 10, 235-251.

Christianen, M.J., Govers, L.L., Bouma, T.J., Kiswara, W., Roelofs, J.G., Lamers, L.P., and van Katwijk, M.M. (2012). Marine megaherbivore grazing may increase seagrass tolerance to high nutrient loads. Journal of Ecology 100, 546-560.

Christianen, M.J., Herman, P.M., Bouma, T.J., Lamers, L.P., van Katwijk, M.M., van der Heide, T., Mumby, P.J., Silliman, B.R., Engelhard, S.L., van de Kerk, M., et al. (2014). Habitat collapse due to overgrazing threatens turtle conservation in marine protected areas. Proceedings of the Royal Society of London B: Biological Sciences 281, 20132890.

Cook, K., Vanderklift, M.A., and Poore, A.G. (2011). Strong effects of herbivorous amphipods on epiphyte biomass in a temperate seagrass meadow. Marine Ecology Progress Series 442, 263-269.

Creel, S., Christianson, D., Liley, S., and Winnie, J.A. (2007). Predation risk affects reproductive physiology and demography of elk. Science 315, 960-960.

Cruz-Rivera, E., and Hay, M. (2001). Macroalgal traits and the feeding and fitness of an herbivorous amphipod: the roles of selectivity, mixing, and compensation. Marine Ecology Progress Series 218, 249-266.

Dayton, P.K., Thrush, S.F., Agardy, M.T., and Hofman, R.J. (1995). Environmental effects of marine fishing. Aquatic Conservation: Marine and Freshwater Ecosystems 5, 205-232.

De los Santos, C.B., Brun, F.G., Onoda, Y., Cambridge, M.L., Bouma, T.J., Vergara, J.J., and Pérez-Lloréns, J.L. (2012). Leaf-fracture properties correlated with nutritional traits in nine Australian seagrass species: implications for susceptibility to herbivory. Marine Ecology Progress Series 458.

Dennison, W.C., Orth, R.J., Moore, K.A., Stevenson, J.C., Carter, V., Kollar, S., Bergstrom, P.W., and Batiuk, R.A. (1993). Assessing water quality with submersed aquatic vegetation. BioScience 86-94. 
Dewsbury, B.M., and Fourqurean, J.W. (2010). Artificial reefs concentrate nutrients and alter benthic community structure in an oligotrophic, subtropical estuary. Bulletin of Marine Science 86, 813-829.

Dill, L.M., Heithaus, M.R., and Walters, C.J. (2003). Behaviorally mediated indirect interactions in marine communities and their conservation implications. Ecology 84, 1151-1157.

Domning, D. (2001). Sirenians, seagrasses, and Cenozoic ecological change in the Caribbean. Palaeogeography, Paleoclimatology, Paleoecology 166, 27-50. Duarte, C.M. (1999). Seagrass ecology at the turn of the millennium: challenges for the new century. Aquatic Botany 65, 7-20.

Duffy, J.E., and Harvilicz, A.M. (2001). Species-specific impacts of grazing amphipods in an eelgrass-bed community. Marine Ecology Progress Series 223, 201-211.

Duffy, J., Richardson, J., and Canuel, E. (2003). Grazer diversity effects on ecosystem functioning in seagrass beds. Ecology Letters 6, 637-645.

Duffy, J.E., Macdonald, K.S., Rhode, J.M., and Parker, J.D. (2001). Grazer diversity, functional redundancy, and productivity in seagrass beds: an experimental test. Ecology 82, 2417-2434.

Duffy, J.E., Moksnes, P.I., and Hughes, A.R. (2013). Ecology of Seagrass Communities. In Marine Community Ecology and Conservation, M.D. Bertness, J.F. Bruno, B.R. Silliman, and J.J. Stachowicz, eds. (Sunderland: Sinauer Associates), pp. 271-297.

Dulvy, N.K., Fowler, S.L., Musick, J.A., Cavanagh, R.D., Kyne, P.M., Harrison, L.R., Carlson, J.K., Davidson, L.N., Fordham, S.V., Francis, M.P., et al. (2014). Extinction risk and conservation of the world's sharks and rays. eLife Sciences 3, e00590.

Ebrahim, A., Olds, A.D., Maxwell, P.S., Pitt, K.A., Burfeind, D.D., and Connolly, R.M. (2014). Herbivory in a subtropical seagrass ecosystem: separating the functional role of different grazers. Mar Ecol Prog Ser 511, 83-91.

Ehrlich, P.R., and Raven, P.H. (1964). Butterflies and plants: a study in coevolution. Evolution 586-608.

Eklöf, J.S., De la Torre-Castro, M., Gullström, M., Uku, J., Muthiga, N., Lyimo, T., and Bandeira, S.O. (2008). Sea urchin overgrazing of seagrasses: a review of current knowledge on causes, consequences, and management. Estuarine, Coastal and Shelf Science 79, 569-580. 
Eklöf, J.S., McMahon, K., and Lavery, P.S. (2010). Effects of multiple disturbances in seagrass meadows: shading decreases resilience to grazing. Marine and Freshwater Research 60, 1317-1327.

Eklöf, J.S., Alsterberg, C., Havenhand, J.N., Sundbäck, K., Wood, H.L., and Gamfeldt, L. (2012). Experimental climate change weakens the insurance effect of biodiversity. Ecol Lett 15, 864-872.

Emmett Duffy, J., Paul Richardson, J., and France, K.E. (2005). Ecosystem consequences of diversity depend on food chain length in estuarine vegetation. Ecology Letters 8, 301-309.

Ferretti, F., Worm, B., Britten, G.L., Heithaus, M.R., and Lotze, H.K. (2010). Patterns and ecosystem consequences of shark declines in the ocean. Ecology Letters 13, 1055-1071.

Fodrie, F., Heck, K.L., Powers, S.P., Graham, W.M., and Robinson, K.L. (2010). Climate-related, decadal-scale assemblage changes of seagrass-associated fishes in the northern Gulf of Mexico. Global Change Biology 16, 48-59.

Fourqurean, J.W., Powell, G.V., Kenworthy, W.J., and Zieman, J.C. (1995). The effects of long-term manipulation of nutrient supply on competition between the seagrasses Thalassia testudinum and Halodule wrightii in Florida Bay. Oikos 349-358.

Fourqurean, J.W., Moore, T.O., Fry, B., and Hollibaugh, J.T. (1997). Spatial and temporal variation in $\mathrm{C}: \mathrm{N}: \mathrm{P}$ ratios, $\delta 15 \mathrm{~N}$, and $\delta 13 \mathrm{C}$ of eelgrass Zostera marina as indicators of ecosystem processes, Tomales Bay, California, USA. Mar. Ecol. Prog. Ser 157, 147-157.

Fourqurean, J.W., Escorcia, S.P., Anderson, W.T., and Zieman, J.C. (2005). Spatial and seasonal variability in elemental content, $\delta 13 \mathrm{C}$, and $\delta 15 \mathrm{~N}$ of Thalassia testudinum from South Florida and its implications for ecosystem studies. Estuaries 28, 447-461.

Fourqurean, J.W., Marbà, N., Duarte, C.M., Díaz-Almela, E., and Ruiz-Halpern, S. (2007). Spatial and temporal variation in the elemental and stable isotopic content of the seagrasses Posidonia oceanica and Cymodocea nodosa from the Illes Balears, Spain. Marine Biology 151, 219-232.

Fourqurean, J.W., Duarte, C.M., Kennedy, H., Marbà, N., Holmer, M., Mateo, M.A., Apostolaki, E.T., Kendrick, G.A., Krause-Jensen, D., McGlathery, K.J., et al. (2012). Seagrass ecosystems as a globally significant carbon stock. Nature Geoscience 5, 505-509. 
Fourqurean, J.W., Manuel, S.A., Coates, K.A., Kenworthy, W.J., and Boyer, J.N. (2015). Water quality, isoscapes and stoichioscapes of seagrasses indicate general $\mathrm{P}$ limitation and unique $\mathrm{N}$ cycling in shallow water benthos of Bermuda. Biogeosciences 12, 6235-6249.

Fraser, M.W., Kendrick, G.A., Statton, J., Hovey, R.K., Zavala-Perez, A., and Walker, D.I. (2014). Extreme climate events lower resilience of foundation seagrass at edge of biogeographical range. J Ecol 102, 1528-1536.

Garthwin, R.G., Poore, A.G.B., and Vergés, A. (2014). Seagrass tolerance to herbivory under increased ocean temperatures. Marine Pollution Bulletin 83, 475-482.

Ghedini, G., Russell, B.D., and Connell, S.D. (2015). Trophic compensation reinforces resistance: herbivory absorbs the increasing effects of multiple disturbances. Ecology Letters 18, 182-187.

Goecker, M.E., Heck Jr, K.L., and Valentine, J.F. (2005). Effects of nitrogen concentrations in turtlegrass Thalassia testudinum on consumption by the bucktooth parrotfish Sparisoma radians. Marine Ecology Progress Series 286, 239-248.

Hairston, N.G., Smith, F.E., and Slobodkin, L.B. (1960). Community structure, population control, and competition. American Naturalist 421-425.

Hay, M.E. (1986). Associational plant defenses and the maintenance of species diversity: turning competitors into accomplices. American Naturalist 617-641.

Hays, C.G. (2005). Effect of nutrient availability, grazer assemblage and seagrass source population on the interaction between Thalassia testudinum (turtle grass) and its algal epiphytes. Journal of Experimental Marine Biology and Ecology 314, 53 68.

Heck, K.L., and Valentine, J.F. (1995). Sea urchin herbivory: evidence for long-lasting effects in subtropical seagrass meadows. Journal of Experimental Marine Biology and Ecology 189, 205-217.

Heck, K.L., and Valentine, J.F. (2006). Plant-herbivore interactions in seagrass meadows. Journal of Experimental Marine Biology and Ecology 330, 420-436.

Heck, K.L., and Valentine, J.F. (2007). The primacy of top-down effects in shallow benthic ecosystems. Estuaries and Coasts 30, 371-381.

Heck, K.L., Pennock, J.R., Valentine, J.F., Coen, L.D., and Sklenar, S.A. (2000). Effects of nutrient enrichment and small predator density on seagrass ecosystems: An experimental assessment. Limnol. Oceanogr. 45, 1041-1057. 
Heck Jnr, K.L., Hays, G., and Orth, R.J. (2003). Critical evaluation of the nursery role hypothesis for seagrass meadows. Marine Ecology Progress Series 253, 123-136.

Heide, T. van der, Govers, L.L., Fouw, J. de, Olff, H., Geest, M. van der, Katwijk, M.M. van, Piersma, T., Koppel, J. van de, Silliman, B.R., Smolders, A.J.P., van Gils, J.A. (2012). A Three-Stage Symbiosis Forms the Foundation of Seagrass Ecosystems. Science 336, 1432-1434.

van der Heide, T., van Nes, E.H., Geerling, G.W., Smolders, A.J., Bouma, T.J., and van Katwijk, M.M. (2007). Positive feedbacks in seagrass ecosystems: implications for success in conservation and restoration. Ecosystems 10, 1311-1322.

van der Heide, T., van Nes, E.H., van Katwijk, M.M., Olff, H., and Smolders, A.J. (2011). Positive feedbacks in seagrass ecosystems - evidence from large-scale empirical data. PloS One 6, e16504.

Heithaus, M.R. (2004). Fish communities of subtropical seagrass meadows and associated habitats in Shark Bay, Western Australia. Bulletin of Marine Science $75,79-99$.

Heithaus, M.R. (2005). Habitat use and group size of Piedcormorants (Phalacrocorax varius) in a seagrass ecosystem: possible effects of food abundance and predation risk. Marine Biology 147, 27-35.

Heithaus, M.R. Predators, prey, and ecological roles of sea turtles. In Biology of Sea Turtles, J.J. Wyneken, K. Lohman, and J.A. Musick, eds.

Heithaus, M., and Dill, L. (2006). Does tiger shark predation risk influence foraging habitat use by bottlenose dolphins at multiple spatial scales? Oikos 114, 257-264.

Heithaus, M.R., and Dill, L.M. (2002). Food availability and tiger shark predation risk influence bottlenose dolphin habitat use. Ecology 83, 480-491.

Heithaus, M.R., Frid, A., Wirsing, A.J., Dill, L.M., Fourqurean, J.W., Burkholder, D., Thomson, J., and Bejder, L. (2007). State-dependent risk-taking by green sea turtles mediates top-down effects of tiger shark intimidation in a marine ecosystem. Journal of Animal Ecology 76, 837-844.

Heithaus, M.R., Wirsing, A.J., Thomson, J.A., and Burkholder, D.A. (2008a). A review of lethal and non-lethal effects of predators on adult marine turtles. Journal of Experimental Marine Biology and Ecology 356, 43-51.

Heithaus, M.R., Frid, A., Wirsing, A.J., and Worm, B. (2008b). Predicting ecological consequences of marine top predator declines. Trends in Ecology \& Evolution $23,202-210$. 
Heithaus, M.R., Wirsing, A.J., and Dill, L.M. (2012). The ecological importance of intact top-predator populations: a synthesis of 15 years of research in a seagrass ecosystem. Marine and Freshwater Research 63, 1039-1050.

Heithaus, M.R., Alcoverro, T., Arthur, R., Burkholder, D.A., Coates, K.A., Christianen, M.J., Kelkar, N., Manuel, S.A., Wirsing, A.J., Kenworthy, W.J., et al. (2014). Seagrasses in the age of sea turtle conservation and shark overfishing. Frontiers in Marine Science 1, 28.

Helmuth, B., Mieszkowska, N., Moore, P., and Hawkins, S.J. (2006). Living on the Edge of Two Changing Worlds: Forecasting the Responses of Rocky Intertidal Ecosystems to Climate Change. Annual Review of Ecology, Evolution, and Systematics 37, 373-404.

Hemminga, M.A., and Duarte, C.M. (2000). Seagrass ecology (Cambridge University Press).

Hillebrand, H., Borer, E.T., Bracken, M.E., Cardinale, B.J., Cebrian, J., Cleland, E.E., Elser, J.J., Gruner, D.S., Stanley Harpole, W., Ngai, J.T., Sandin, S., Seabloom, E.W., Shurin, J.B., Smith, J.E., Smith, M.D. (2009). Herbivore metabolism and stoichiometry each constrain herbivory at different organizational scales across ecosystems. Ecology Letters 12, 516-527.

Holbrook, S.J., Reed, D.C., Hansen, K., and Blanchette, C.A. (2000). Spatial and temporal patterns of predation on seeds of the surfgrass Phyllospadix torreyi. Marine Biology 136, 739-747.

Holzer, K.K., Rueda, J.L., and McGlathery, K.J. (2011). Differences in the feeding ecology of two seagrass-associated snails. Estuaries and Coasts 34, 1140-1149.

del Hoyo, J., Elliott, A., and Sargatal, J. (1992). Handbook of the Birds of the World. Vol. 1. Ostrich to Ducks.(Lynx Edicions: Barcelona) (ISBN 84-87334-10-5).

Hughes, A.R.R., Bando, K.J., Rodriguez, L.F., and Williams, S.L. (2004). Relative effects of grazers and nutrients on seagrasses: a meta-analysis approach. Marine Ecology-Progress Series 282.

Humphries, P., Hyndes, G.A., and Potter, I.C. (1992). Comparisons between the diets of distant taxa (teleost and cormorant) in an Australian estuary. Estuaries 15, 327334.

Jackson, J.B. (2001). What was natural in the coastal oceans? Proceedings of the National Academy of Sciences 98, 5411-5418. 
Jackson, J.B., Kirby, M.X., Berger, W.H., Bjorndal, K.A., Botsford, L.W., Bourque, B.J., Bradbury, R.H., Cooke, R., Erlandson, J., Estes, J.A., et al. (2001). Historical overfishing and the recent collapse of coastal ecosystems. Science 293, 629-637.

Jernakoff, P., and Nielsen, J. (1997). The relative importance of amphipod and gastropod grazers in Posidonia sinuosa meadows. Aquatic Botany 56, 183-202.

Karez, R., Engelbert, S., and Sommer, U. (2000). “Co-consumption” and "protective coating": two new proposed effects of epiphytes on their macroalgal hosts in mesograzer-epiphyte-host interactions. Marine Ecology. Progress Series 205, 8593.

Kelkar, N., Arthur, R., Marbà, N., and Alcoverro, T. (2013). Greener pastures? High -density feeding aggregations of green turtles precipitate species shifts in seagrass meadows. Journal of Ecology 101, 1158-1168.

Kendrick, G.A., Aylward, M.J., Hegge, B.J., Cambridge, M.L., Hillman, K., Wyllie, A., and Lord, D.A. (2002). Changes in seagrass coverage in Cockburn Sound, Western Australia between 1967 and 1999. Aquatic Botany 73, 75-87.

Kirkman, H., and Reid, D.D. (1979). A study of the role of the seagrass Posidonia australis in the carbon budget of an estuary. Aquatic Botany 7, 173-183.

Kirsch, K.D., Valentine, J.F., and Heck, K.L. (2002). Parrotfish grazing on turtlegrass Thalassia testudinum: evidence for the importance of seagrass consumption in food web dynamics of the Florida Keys National Marine Sanctuary. Marine Ecology Progress Series 227, 71-85.

Klumpp, D., Howard, R., and Pollard, D. (1989). Trophodynamics and nutritional ecology of seagrass communities. In Biology of Seagrasses: A Treatise on the Biology of Seagrasses with Special Reference to the Australian Region, A. Larkum, and A. McComb, eds. (Amsterdam: Elsevier), pp. 394-457.

Kordas, R.L., Harley, C.D.G., and O’Connor, M.I. (2011). Community ecology in a warming world: The influence of temperature on interspecific interactions in marine systems. Journal of Experimental Marine Biology and Ecology 400, 218226.

Lanyon, J., Limpus, C., and Marsh, H. (1989). Dugongs and turtles: Grazers in the seagrass ecosystem. In Biology of Seagrasses, (Elsevier), pp. 610-634.

Larkum, A.W.D., and West, R.J. (1990). Long-term changes of seagrass meadows in Botany Bay, Australia. Aquatic Botany 37, 55-70. 
Larkum, A.W.D., McComb, A.J., and Shephard, S.A. (1989). Biology of seagrasses: a treatise on the biology of seagrasses with special reference to the Australian region.

Last, P.R., White, W.T., Gledhill, D.C., Hobday, A.J., Brown, R., Edgar, G.J., and Pecl, G. (2011). Long-term shifts in abundance and distribution of a temperate fish fauna: a response to climate change and fishing practices. Global Ecology and Biogeography 20, 58-72.

Lee, C.-L., Huang, Y.-H., Chung, C.-Y., Hsiao, S.-C., and Lin, H.-J. (2015). Herbivory in multi-species, tropical seagrass beds. MEPS 525, 65-80.

Lima, S.L. (1998). Nonlethal effects in the ecology of predator-prey interactions. BioScience 48, 25-34.

Ling, S.D. (2008). Range expansion of a habitat-modifying species leads to loss of taxonomic diversity: a new and impoverished reef state. Oecologia 156, 883-894.

Lipkin, Y. (1975). Halophila stipulacea, a review of a successful immigration. Aquatic Botany 1, 203-215.

Lobel, P.S., and Ogden, J.C. (1981). Foraging by the herbivorous parrotfish Sparisoma radians. Mar. Biol. 64, 173-183.

Long, B.G., and Skewes, T.D. (1996). On the trail of seagrass dieback in Torres Strait. Professional Fisherman (February) 15-18.

Long, H.A., and Grosholz, E.D. (2015). Overgrowth of eelgrass by the invasive colonial tunicate Didemnum vexillum: Consequences for tunicate and eelgrass growth and epifauna abundance. Journal of Experimental Marine Biology and Ecology 473, 188-194.

Lowther, A.D., Harcourt, R.G., Hamer, D.J., and Goldsworthy, S.D. (2011). Creatures of habit: foraging habitat fidelity of adult female Australian sea lions. Marine Ecology Progress Series 443, 249-263.

MacArthur, L.D., and Hyndes, G.A. (2007). Varying foraging strategies of Labridae in seagrass habitats: Herbivory in temperate seagrass meadows? Journal of Experimental Marine Biology and Ecology 340, 247-258.

Mach, M.E., Wyllie-Echeverria, S., and Chan, K.M. (2014). Ecological effect of a nonnative seagrass spreading in the Northeast Pacific: A review of Zostera japonica. Ocean \& Coastal Management 102, 375-382. 
Madin, E.M.P., Dill, L.M., Ridlon, A.D., Heithaus, M.R., and Warner, R.R. (2016). Human activities change marine ecosystems by altering predation risk. Global Change Biology 22, 44-60.

Masini, R.J., Anderson, P.K., and McComb, A.J. (2001). A Halodule-dominated community in a subtropical embayment: physical environment, productivity, biomass, and impact of dugong grazing. Aquatic Botany 71, 179-197.

McCauley, D.J., Pinsky, M.L., Palumbi, S.R., Estes, J.A., Joyce, F.H., and Warner, R.R. (2015). Marine defaunation: Animal loss in the global ocean. Science 347, 1255641 .

McGlathery, K.J. (1995). Nutrient and grazing influences on a subtropical seagrass community. Marine Ecology Progress Series. Oldendorf 122, 239-252.

Mcleod, E., Chmura, G.L., Bouillon, S., Salm, R., Björk, M., Duarte, C.M., Lovelock, C.E., Schlesinger, W.H., and Silliman, B.R. (2011). A blueprint for blue carbon: toward an improved understanding of the role of vegetated coastal habitats in sequestering CO2. Frontiers in Ecology and the Environment 9, 552-560.

McSkimming, C., Tanner, J.E., Russell, B.D., and Connell, S.D. (2015). Compensation of nutrient pollution by herbivores in seagrass meadows. Journal of Experimental Marine Biology and Ecology 471, 112-118.

Mertens, N.L., Russell, B.D., and Connell, S.D. (2015). Escaping herbivory: ocean warming as a refuge for primary producers where consumer metabolism and consumption cannot pursue. Oecologia 179, 1223-1229.

Moksnes, P.-O., Gullström, M., Tryman, K., and Baden, S. (2008). Trophic cascades in a temperate seagrass community. Oikos 117, 763-777.

van Montfrans, J., Wetzel, R.L., and Orth, R.J. (1984). Epiphyte-grazer relationships in seagrass meadows: consequences for seagrass growth and production. Estuaries 7, 289-309.

Myers, R.A., and Worm, B. (2003). Rapid worldwide depletion of predatory fish communities. Nature 423, 280-283.

Myers, R.A., Baum, J.K., Shepherd, T.D., Powers, S.P., and Peterson, C.H. (2007). Cascading effects of the loss of apex predatory sharks from a coastal ocean. Science 315, 1846-1850.

Nakaoka, M. (2002). Predation on seeds of seagrasses Zostera marina and Zostera caulescens by a tanaid crustacean Zeuxo sp. Aquatic Botany 72, 99-106. 
Nakaoka, M. (2005). Plant-animal interactions in seagrass beds: ongoing and future challenges for understanding population and community dynamics. Population Ecology 47, 167-177.

Newell, R.I. (2004). Ecosystem influences of natural and cultivated populations of suspension-feeding bivalve molluscs: a review. Journal of Shellfish Research 23, $51-62$.

Newell, R.I., and Koch, E.W. (2004). Modeling seagrass density and distribution in response to changes in turbidity stemming from bivalve filtration and seagrass sediment stabilization. Estuaries 27, 793-806.

Nienhuis, P.H., and Groenendijk, A.M. (1986). Consumption of eelgrass (Zostera marina) by birds and invertebrates: an annual budget. Marine Ecology Progress Series 29.

Norse, E.A. (1993). Global marine biological diversity: a strategy for building conservation into decision making (Island Press).

Orth, R.J. (1975). Destruction of eelgrass, Zostera marina, by the cownose ray, Rhinoptera bonasus, in the Chesapeake Bay. Chesapeake Science 16, 205-208.

Orth, R.J., and Van Montfrans, J. (1984). Epiphyte-seagrass relationships with an emphasis on the role of micrograzing: a review. Aquatic Botany 18, 43-69.

Orth, R.J., Carruthers, T.J.B., Dennison, W.C., Duarte, C.M., Fourqurean, J.W., Heck, K.L., Hughes, A.R., Kendrick, G.A., Kenworthy, W.J., Olyarnik, S., Short, F.T., Waycott, M., Williams, S.L. (2006a). A Global Crisis for Seagrass Ecosystems. BioScience 56, 987-996.

Orth, R.J., Kendrick, G.A., and Marion, S.R. (2006b). Predation on Posidonia australis seeds in seagrass habitats of Rottnest Island, Western Australia: patterns and predators. Marine Ecology Progress Series 313, 105-114.

Paine, R.T. (1980). Food Webs: Linkage, Interaction Strength and Community Infrastructure. Journal of Animal Ecology 49, 667-685.

Parmesan, C., and Yohe, G. (2003). A globally coherent fingerprint of climate change impacts across natural systems. Nature 421, 37-42.

Pauly, D., Christensen, V., Dalsgaard, J., Froese, R., and Torres, F. (1998). Fishing Down Marine Food Webs. Science 279, 860-863. 
Peacor, S.D., and Werner, E.E. (2001). The contribution of trait-mediated indirect effects to the net effects of a predator. Proceedings of the National Academy of Sciences 98, 3904-3908.

Pearce, A.F., and Feng, M. (2013). The rise and fall of the "marine heat wave" off Western Australia during the summer of 2010/2011. Journal of Marine Systems $111,139-156$.

Peterson, B.J., and Heck Jr, K.L. (2001). Positive interactions between suspension -feeding bivalves and seagrass-a facultative mutualism. Marine Ecology Progress Series 213, 143-155.

Peterson, C.H., Fodrie, J.F., Summerson, H.C. \& Powers, S.P. (2001). Site-specific and density-dependent extinction of prey by schooling rays: generation of a population sink in top-quality habitat for bay scallops. Oecologia, 129, 349-356.

Pinnegar, J.K., Polunin, N.V.C., Francour, P., Badalamenti, F., Chemello, R., Harmelin -Vivien, M.-L., Hereu, B., Milazzo, M., Zabala, M., d'Anna, G., et al. (2000). Trophic cascades in benthic marine ecosystems: lessons for fisheries and protected-area management. Environmental Conservation 27, 179-200.

Poloczanska, E.S., Brown, C.J., Sydeman, W.J., Kiessling, W., Schoeman, D.S., Moore, P.J., Brander, K., Bruno, J.F., Buckley, L.B., Burrows, M.T., Duarte, C.M., Halpern, B.S., Holding, J., Kappel, C.V., O’Connor, M.I., Pandolfi, J.M., Parmesan, C., Schwing, F., Thompson, S.A., Richardson, A.J. (2013). Global imprint of climate change on marine life. Nature Climate Change 3, 919-925.

Poore, A.G., Campbell, A.H., and Steinberg, P.D. (2009). Natural densities of mesograzers fail to limit growth of macroalgae or their epiphytes in a temperate algal bed. Journal of Ecology 97, 164-175.

Poore, A.G., Campbell, A.H., Coleman, R.A., Edgar, G.J., Jormalainen, V., Reynolds, P.L., Sotka, E.E., Stachowicz, J.J., Taylor, R.B., Vanderklift, M.A., Duffy, J.E. (2012). Global patterns in the impact of marine herbivores on benthic primary producers. Ecology Letters 15, 912-922.

Powell, G.V., Fourqurean, J.W., Kenworthy, W.J., and Zieman, J.C. (1991). Bird colonies cause seagrass enrichment in a subtropical estuary: observational and experimental evidence. Estuarine, Coastal and Shelf Science 32, 567-579.

Prado, P., and Heck, K.L. (2011). Seagrass selection by omnivorous and herbivorous consumers: determining factors. Marine Ecology Progress Series 429, 45-55. 
Prado, P., Romero, J., and Alcoverro, T.(2010). Nutrient status, plant availability and seasonal forcing mediate fish herbivory in temperate seagrass beds. Marine Ecology Progress Series 409, 229-239.

Preen, A. (1995). Impacts of dugong foraging on seagrass habitats: observational and experimental evidence for cultivation grazing. Marine Ecology Progress Series. Oldendorf 124, 201-213.

Preen, A.R., Marsh, H., Lawler, I.R., Prince, R.I.T., and Shepherd, R. (1997). Distribution and abundance of dugongs, turtles, dolphins and other megafauna in Shark Bay, Ningaloo Reef and Exmouth Gulf, Western Australia. Wildlife Research 24, 185-208.

Randall, J.E. (1965). Grazing Effect on Sea Grasses by Herbivorous Reef Fishes in the West Indies. Ecology 46, 255-260.

Reynolds, L.K., Carr, L.A., Boyer, K.E., and others (2012). A non-native amphipod consumes eelgrass inflorescences in San Francisco Bay. Marine Ecology Progress Series 451, 107-118.

Reynolds, P.L., Richardson, J.P., and Duffy, J.E. (2014). Field experimental evidence that grazers mediate transition between microalgal and seagrass dominance. Limnology and Oceanography 59, 1053-1064.

Ricklefs, R., and Miller, G. (1999). Ecology. (W.H. Freeman).

Rose, C.D., Sharp, W.C., Kenworthy, W.J., Hunt, J.H., Lyons, W.G., Prager, E.J., Valentine, J.F., Hall, M.O., Whitfield, P.E., and Fourqurean, J.W. (1999). Overgrazing of a large seagrass bed by the sea urchin Lytechinus variegatus in Outer Florida Bay. Marine Ecology Progress Series 190, 211-222.

Rosenblatt, A.E., and Schmitz, O.J. (2014). Interactive effects of multiple climate change variables on trophic interactions: a meta-analysis. Climate Change Responses 1, 8.

Rossini, R.A., Rueda, J.L., and Tibbetts, I.R. (2014). Feeding ecology of the seagrass -grazing nerite Smaragdia souverbiana (Montrouzier, 1863) in subtropical seagrass beds of eastern Australia. Journal of Molluscan Studies eyu003.

Rueda, J.L., and Salas, C. (2007). Trophic dependence of the emerald neritid Smaragdia viridis (Linnaeus, 1758) on two seagrasses from European coasts. J. Mollus. Stud. 73, 211-214. 
Russell, B., and Connell, S. (2007). Response of grazers to sudden nutrient pulses in oligotrophic versus eutrophic conditions. Marine Ecology Progress Series 349, 73-80.

Sanmart, N., Saiz, L., Llagostera, I., Prez, M., and Romero, J. (2014). Tolerance responses to simulated herbivory in the seagrass Cymodocea nodosa. Marine Ecology Progress Series 517, 159-169.

Schmitz, O.J. (2008). Effects of predator hunting mode on grassland ecosystem function. Science 319, 952-954.

Schmitz, O.J., Beckerman, A.P., and O’Brien, K.M. (1997). Behaviorally mediated trophic cascades: effects of predation risk on food web interactions. Ecology 78, 1388-1399.

Schmitz, O.J., Krivan, V., and Ovadia, O. (2004). Trophic cascades: the primacy of trait -mediated indirect interactions. Ecology Letters 7, 153-163.

Sheppard, J.K., Marsh, H., Jones, R.E., and Lawler, I.R. (2010). Dugong habitat use in relation to seagrass nutrients, tides, and diel cycles. Marine Mammal Science 26, $855-879$.

Shurin, J.B., Borer, E.T., Seabloom, E.W., Anderson, K., Blanchette, C.A., Broitman, B., Cooper, S.D., and Halpern, B.S. (2002). A cross-ecosystem comparison of the strength of trophic cascades. Ecology Letters 5, 785-791.

Simpfendorfer, C.A., and Milward, N.E. (1993). Utilisation of a tropical bay as a nursery area by sharks of the families Carcharhinidae and Sphyrnidae. Environ Biol Fish $37,337-345$.

Smale, D.A., and Wernberg, T. (2013). Extreme climatic event drives range contraction of a habitat-forming species. Proceedings of the Royal Society of London B: Biological Sciences 280, 20122829.

Steele, L., and Valentine, J.F. (2015). Seagrass deterrence to mesograzer herbivory: evidence from mesocosm experiments and feeding preference trials.

Strong, D.R. (1992). Are trophic cascades all wet? Differentiation and donor-control in speciose ecosystems. Ecology 73, 747-754.

Sumoski, S.E., and Orth, R.J. (2012). Biotic dispersal in eelgrass Zostera marina. Marine Ecology. Progress Series 471, 1-10. 
Targett, N.M., Targett, T.E., Vrolijk, N.H., and Ogden, J.C. (1986). Effect of macrophyte secondary metabolites on feeding preferences of the herbivorous parrotfish Sparisoma radians. Marine Biology 92, 141-148.

Tussenbroek, B.I. van, and Brearley, A. (1998). Isopod burrowing in leaves of turtle grass, Thalassia testudinum, in a Mexican Caribbean reef lagoon. Mar. Freshwater Res. 49, 525-531.

Tussenbroek, B.I. van, and Muhlia-Montero, M. (2012). Can floral consumption by fish shape traits of seagrass flowers? Evol Ecol 27, 269-284.

Tussenbroek, B.I. van, Monroy-Velazquez, L.V., and Solis-Weiss, V. (2012). Meso -fauna foraging on seagrass pollen may serve in marine zoophilous pollination. Marine Ecology Progress Series 469, 1.

Valentine, J.F., and Heck, K.L. (1991). The role of sea urchin grazing in regulating subtropical seagrass meadows: evidence from field manipulations in the northern Gulf of Mexico. Journal of Experimental Marine Biology and Ecology 154, 215230.

Valentine, J.F., and Heck, K.L. (2001). The role of leaf nitrogen content in determining turtlegrass (Thalassia testudinum) grazing by a generalized herbivore in the northeastern Gulf of Mexico. Journal of Experimental Marine Biology and Ecology 258, 65-86.

Valentine, J.F., Heck, K.L., Jr, J.B., and Webb, D. (1997). Experimental evidence that herbivory increases shoot density and productivity in a subtropical turtlegrass (Thalassia testudinum ) meadow. Oecologia 112, 193-200.

Vergés, A., Becerro, M.A., Alcoverro, T., and Romero, J. (2006). Variation in multiple traits of vegetative and reproductive seagrass tissues influences plant-herbivore interactions. Oecologia 151, 675-686.

Vergés, A., Pérez, M., Alcoverro, T., and Romero, J. (2008). Compensation and resistance to herbivory in seagrasses: induced responses to simulated consumption by fish. Oecologia 155, 751-760.

Vergés, A., Alcoverro, T., and Romero, J. (2010). Plant defences and the role of epibiosis in mediating within-plant feeding choices of seagrass consumers. Oecologia 166, 381-390.

Vergés, A., Steinberg, P.D., Hay, M.E., Poore, A.G., Campbell, A.H., Ballesteros, E., Heck, K.L., Booth, D.J., Coleman, M.A., Feary, D.A., Figueira, W., Langlois, T., Marzinelli, E.M., Mizerek, T., Mumby, P.J., Nakamura, Y., Roughan, M., van Sebille, E., Gupta, A.S., Smale, D.A., Tomas, F., Wernberg, T., Wilson, S.K. 
(2014). The tropicalization of temperate marine ecosystems: climate-mediated changes in herbivory and community phase shifts. In: Proc. R. Soc. B. The Royal Society, 281, 20140846.

Verhoeven, M.P.C., Kelaher, B.P., Bishop, M.J., and Ralph, P.J. (2012). Epiphyte grazing enhances productivity of remnant seagrass patches. Austral Ecology 37, 885-892.

Walther, G.-R., Post, E., Convey, P., Menzel, A., Parmesan, C., Beebee, T.J.C., Fromentin, J.-M., Hoegh-Guldberg, O., and Bairlein, F. (2002). Ecological responses to recent climate change. Nature 416, 389-395.

Wassenberg, T. (1990). Seasonal feeding on Zostera capricorni seeds by Juvenile Penaeus esculentus (Crustacea: Decapoda) in Moreton Bay, Queensland. Marine and Freshwater Research 41, 301-310.

Waycott, M., Duarte, C.M., Carruthers, T.J.B., Orth, R.J., Dennison, W.C., Olyarnik, S., Calladine, A., Fourqurean, J.W., Heck, K.L., Hughes, A.R., et al. (2009). Accelerating loss of seagrasses across the globe threatens coastal ecosystems. Proceedings of the National Academy of Sciences 106, 12377-12381.

Wernberg, T., Russell, B.D., Moore, P.J., Ling, S.D., Smale, D.A., Campbell, A., Coleman, M.A., Steinberg, P.D., Kendrick, G.A., and Connell, S.D. (2011a). Impacts of climate change in a global hotspot for temperate marine biodiversity and ocean warming. Journal of Experimental Marine Biology and Ecology 400, $7-16$.

Wernberg, T., Russell, B.D., Thomsen, M.S., Gurgel, C.F.D., Bradshaw, C.J., Poloczanska, E.S., and Connell, S.D. (2011b). Seaweed communities in retreat from ocean warming. Current Biology 21, 1828-1832.

Wernberg, T., Smale, D.A., Tuya, F., Thomsen, M.S., Langlois, T.J., De Bettignies, T., Bennett, S., and Rousseaux, C.S. (2013). An extreme climatic event alters marine ecosystem structure in a global biodiversity hotspot. Nature Climate Change 3, $78-82$.

Werner, E.E., and Peacor, S.D. (2003). A review of trait-mediated indirect interactions in ecological communities. Ecology 84, 1083-1100.

Whalen, M.A., Duffy, J.E., and Grace, J.B. (2013). Temporal shifts in top-down vs. bottom-up control of epiphytic algae in a seagrass ecosystem. Ecology 94, 510520 . 
White, W.T., and Potter, I.C. (2004). Habitat partitioning among four elasmobranch species in nearshore, shallow waters of a subtropical embayment in Western Australia. Marine Biology 145, 1023-1032.

White, K.S., Westera, M.B., and Kendrick, G.A. (2011). Spatial patterns in fish herbivory in a temperate Australian seagrass meadow. Estuarine, Coastal and Shelf Science 93, 366-374.

Willette, D.A., Chalifour, J., Debrot, A.O.D., Engel, M.S., Miller, J., Oxenford, H.A., Short, F.T., Steiner, S.C.C., and Védie, F. (2014). Continued expansion of the trans-Atlantic invasive marine angiosperm Halophila stipulacea in the Eastern Caribbean. Aquatic Botany 112, 98-102.

Williams, S.L. (2007). Introduced species in seagrass ecosystems: Status and concerns. Journal of Experimental Marine Biology and Ecology 350, 89-110.

Williams, S.L., and Heck Jr, K.L. (2001). Seagrass community ecology. Marine Community Ecology 317-337.

Wirsing, A.J., Heithaus, M.R., and Dill, L.M. (2007a). Can you dig it? Use of excavation, a risky foraging tactic, by dugongs is sensitive to predation danger. Animal Behaviour 74, 1085-1091.

Wirsing, A.J., Heithaus, M.R., and Dill, L.M. (2007b). Fear factor: do dugongs (Dugong dugon) trade food for safety from tiger sharks (Galeocerdo cuvier)? Oecologia 153, 1031-1040.

Wirsing, A.J., Heithaus, M.R., and Dill, L.M. (2007c). Living on the edge: dugongs prefer to forage in microhabitats that allow escape from rather than avoidance of predators. Animal Behaviour 74, 93-101.

Wirsing, A.J., Cameron, K.E., and Heithaus, M.R. (2010). Spatial responses to predators vary with prey escape mode. Animal Behaviour 79, 531-537.

Worm, B., and Lotze, H.K. (2006). Effects of eutrophication, grazing, and algal blooms on rocky shores. Limnology and Oceanography 51, 569-579.

Worm, B., Davis, B., Kettemer, L., Ward-Paige, C.A., Chapman, D., Heithaus, M.R., Kessel, S.T., and Gruber, S.H. (2013). Global catches, exploitation rates, and rebuilding options for sharks. Marine Policy 40, 194-204.

Wressnig, A., and Booth, D.J. (2007). Feeding preferences of two seagrass grazing monacanthid fishes. Journal of Fish Biology 71, 272-278. 
Wu, L., Cai, W., Zhang, L., Nakamura, H., Timmermann, A., Joyce, T., McPhaden, M.J., Alexander, M., Qiu, B., Visbeck, M., et al. (2012). Enhanced warming over the global subtropical western boundary currents. Nature Clim. Change 2, 161-166.

Zarnetske, P.L., Skelly, D.K., and Urban, M.C. (2012). Biotic multipliers of climate change. Science 336, 1516-1518.

Zimmerman, R.C., Kohrs, D.G., and Alberte, R.S. (1996). Top-down impact through a bottom-up mechanism: the effect of limpet grazing on growth, productivity and carbon allocation of Zostera marina L.(eelgrass). Oecologia 107, 560-567. 
CHAPTER III

PREDICTING SEAGRASS RECOVERY TIMES AND THEIR IMPLICATIONS

FOLLOWING AN EXTREME CLIMATE EVENT 


\begin{abstract}
Extreme temperature events are predicted to become more frequent and intense as climate change continues, with important implications for ecosystems. Accordingly, there has been growing interest in what drives resilience to climatic disturbances. When a stressor overwhelms the resistance of an ecosystem, its recovery trajectory is susceptible to external influence with implications for ecosystem function and persistence.

Understanding recovery trajectories of seagrass is particularly important because of their roles as foundation species in their ecosystems, the rapid loss of seagrass globally, and variation in life history strategies that impact resilience. Seagrass cover was monitored for three years following a large, heatwave-associated mortality event in the remote ecosystem of Shark Bay, Australia. Though the ecosystem's historically dominant foundational seagrass, Amphibolis antarctica, is capable of rapid recovery from disturbances, no evidence of recovery was observed, likely because of the failure of mechanisms which have driven rapid recovery in other systems (persistence of rhizome beds, sexual reproduction among neighboring beds). Instead, a tropical opportunistic seagrass, Halodule uninervis, expanded throughout the system following the heat wave. These changes in the structure of the Shark Bay seagrass ecosystem- from high to low biomass and structural complexity-are likely to have important implications for ecosystem services and community dynamics, and indicates this ecosystem is highly vulnerable to future disturbances. More generally, my work suggests that seagrass ecosystems typified by a mix of early and late successional species may be particularly likely to exhibit a mismatch between recovery of cover per se and recovery of function following disturbance.
\end{abstract}




\section{Introduction}

Although research into the ecological effects of climate change has largely focused on how organisms and ecosystems will respond to changes in average environmental conditions, there has been an increasing recognition of the ability of extreme climatic events - such as heat waves and droughts - to rapidly alter ecosystems. Climate change is predicted to alter aspects of extreme events, including the frequency and duration of heat waves, heavy precipitation events and droughts, strength of tropical ocean currents, and even the frequency of extremes in the ENSO cycle (IPCC 2014, Wu et al. 2012, Cai et al. 2014, 2015). Such events can induce species range shifts, species die-offs, or changes in community composition, phenology, or primary productivity (e.g., Honnay et al. 2002, Ciais et al. 2005, Inouye 2008, Mantgem et al. 2009, Augspurger 2013). The effects that extreme events can have on ecological processes has implications for ecosystem functioning, and in some cases can trigger regime shifts to persistent, fundamentally different ecosystem states (e.g., Bennett et al. 2015). However, there is considerable uncertainty as to the conditions under which ecological disturbances trigger such shifts. To predict the occurrence of such shifts, it is first necessary to understand what influences resilience to disturbances.

Resilience is defined as the magnitude of disturbance an ecosystem can withstand without shifting into an alternate state (sensu Holling 1973), and can be broken down into two mechanisms: resistance to disturbance and recovery from disturbance (i.e., return time) (Unsworth et al. 2015). Resistance (sensu Carpenter et al. 2001) is the amount of external forcing required to generate a disturbance in an ecosystem, while return time is 
the time it takes for a system to recover from a disturbance (May 1973), the inverse of which is sometimes referred to as stability (e.g., Dai et al. 2015). Ecosystems that recover rapidly from one disturbance exhibit high stability and are more likely to be able to resist subsequent disturbances than ecosystems that recovery slowly (Plus et al. 2003). It is therefore critical to understand not only how ecosystems respond to extreme events (resistance), but how they recover from them, particularly as disturbances become more frequent and the risk of exposure to sequential disturbances increases (IPCC 2014, Smale and Wernberg 2013).

Despite their importance as foundations of coastal ecosystems, seagrass habitats are declining at alarming rates, largely because of impacts from local stressors such as sedimentation and eutrophication (e.g., Short and Wyllie-Echeverria 1996, Waycott et al. 2009). Yet, even remote seagrass ecosystems far removed from local human influence can be vulnerable to large disturbance events such as marine heat waves (e.g., Fraser et al. 2014, Thomson et al. 2015). Such large events, which cannot be managed at local scales, illustrate the danger climate change and altered thermal regimes pose to marine ecosystems, something already well appreciated by coral reef ecologists (e.g., Glynn 1993, Pandolfi 2015). While the potential for extreme climate events to generate widespread ecosystem shifts is becoming increasingly recognized, many gaps still remain in understanding how ecosystems will respond to and recover from such events (Jentsch et al. 2007, Thomson et al. 2015).

Return time of damaged seagrass beds can range from months to centuries (e.g., Walker and McComb 1992, Plus et al. 2003, Orth et al. 2006, Short et al. 2014). One 
factor that can heavily influence these return times is seagrass life history strategy. Seagrass species possess a wide variety of life history traits and inhabit a continuum of successional capabilities, but can often be categorized as late or early successional species (sensu Bazzaz 1979). Late successional seagrasses, such as those in the genera Amphibolis, Posidonia, Thalassia, and Zostera, tend to have relatively large and perennial canopies, often with large stores of carbohydrates in their buried rhizome tissue. These energy stores can confer increased resistance to stressors, and the capability to rapidly refoliate and regenerate shoots from surviving rhizomes if a stressor overcomes their initial resistance (e.g., Peterson et al. 2002, Fraser et al. 2014). However, if rhizomal regeneration is not possible (because of, for example, insufficient rhizome biomass or the extremity of a disturbance), rapid ( $<10 \mathrm{yr})$ return of these seagrasses to pre die-off abundance seems to be heavily dependent on the presence of a seed bank (Preen et al. 1995, Plus et al. 2003, Campbell and McKenzie 2004) or reproductive events from nearby beds (e.g., Orth et al. 2006, Larkum et al. 2006, Tanner 2015). Long return times are likely if reproductive events or refoliation from existing rhizomes do not occur because many larger, "late successional" seagrasses are characterized by relatively slow rhizome elongation rates (Walker et al. 2006), limiting the ability of vegetative expansion to lead recovery when seagrass loss is widespread. Importantly, many late successional seagrasses lack a dormant seed bank, and some genera, like Amphibolis, are viviparous and lack seeds altogether (Larkum et al. 2006). This eliminates one mechanism of disturbance resistance outright and highlights how crucial the key mechanisms of regeneration from below-ground biomass and recruitment from nearby living beds are in rapid return time and resilience of some late successional seagrasses. 
Unlike late successional species, early successional (sensu Bazzaz 1979) seagrasses have adapted to disturbance by reliance on rapid disturbance recovery and expansion as opposed to resistance to disturbance itself (Unsworth et al. 2015). These species, such as those in the genera Halophila and Halodule, generally have small energy stores in rhizome tissue, instead relying on fast rhizome elongation rates and dormant seed banks to rapidly recruit and expand after disturbances (Walker et al. 2006). Early successional species also form relatively sparse and short beds with much lower structural complexity and standing biomass than those composed of late successional seagrasses. The plant traits associated with early and late successional species not only influence the recovery trajectories of mixed seagrass beds, but the functions associated with these beds as they change. As a result, changes in seagrass community assembly following disturbance have implications both for the resilience of the system to future disturbances and for ecosystem function.

While seagrass life history plays an important role in determining return times of seagrasses and resilience of seagrass ecosystem to disturbance, factors like the extent of initial disturbance and local biophysical and biological features can also influence recovery speeds (i.e., return time) and changes in the seagrass community throughout recovery (i.e., recovery trajectories) of seagrass ecosystems (Unsworth et al. 2015). Furthermore, density-dependent Allee effects can generate feedbacks in disturbed seagrass ecosystems that alter the biological or biophysical features of the ecosystem, further complicating recovery predictions. For example, widespread seagrass loss can reduce particle trapping, increase turbidity, promote nutrient efflux-driven phytoplankton blooms, and limit sexual reproduction, promoting the maintenance of a seagrass- 
depauperate state (Fourqurean and Robblee 1999, Van der Heide et al. 2007, Carr et al. 2010, van Tussenbroek et al. 2016). Fast return times of functionally critical species can minimize the impacts of such density-dependent feedbacks in seagrass ecosystems and thus maximize the possibility of persistence while minimizing impacts to the wider seagrass associated community.

The purpose of the present study was to assess the post-disturbance dynamics of the relatively pristine subtropical seagrass ecosystem of Shark Bay, Western Australia, following a widespread marine heat wave that occurred in 2011 and triggered subsequent catastrophic seagrass loss. Specifically, my goals were to assess changes in cover and occurrence of benthic macrophytes (seagrasses and benthic macroalgae) over medium time scales (three years), to better understand the return times and future disturbance resilience for functionally important seagrass species, and to explore potential implications of the observed post-disturbance state on ecosystem function and seagrass associated fauna.

\section{Methods}

\section{Study system}

The study was performed in the Eastern Gulf of Shark Bay $\left(25^{\circ} 45^{\prime} \mathrm{S}, 113^{\circ} 44^{\prime} \mathrm{E}\right)$, Western Australia. Shark Bay is a shallow $(<15 \mathrm{~m}), 13,000 \mathrm{~km}^{2}$ semi-enclosed subtropical embayment situated approximately $800 \mathrm{~km}$ north of Perth. The study area, immediately north of Monkey Mia, consists of a series of near-shore shallow $(<4 \mathrm{~m})$ seagrass banks separated by deep (6-12m), seagrass-depauperate channels (Heithaus 2001, Fig. 1). The bay historically contained over $4000 \mathrm{~km}^{2}$ of seagrass (Walker et al. 
1988), making it one of the largest remaining seagrass ecosystems on earth. Shark Bay's expansive seagrass beds directly or indirectly support a wide variety of megafauna including dugongs (Dugong dugon), green sea turtles (Chelonia mydas), and tiger sharks (Galeocerdo cuvier), a key feature of its status as a UNESCO World Heritage Area. Despite its large size, Shark Bay is almost completely undeveloped with a small human population and relatively few local and regional anthropogenic stressors (Heithaus 2001).

Shark Bay hosts twelve species of seagrasses; eight of tropical and four of temperate evolutionary origin (Walker et al. 1988). Of these, only two species form large, continuous beds: the temperate species Amphibolis antarctica and Posidonia australis. Shark Bay's seagrass assemblage has been historically dominated by $A$. antarctica, which accounted for approximately $85 \%$ of seagrass cover and often formed dense, monospecific stands of 90-100\% cover (Walker et al. 1988, Burkholder et al. 2013a, fig. 1, 3a.). Because of the height and density of A. antarctica beds (200-500 shoots $/ \mathrm{m}$, up to $2 \mathrm{~m}$ tall), this seagrass is a structurally complex ecosystem engineer (sensu Jones et al. 1994) that creates extensive benthic habitat, stabilizes sediment, and contributes significant primary production in this ecosystem (Walker 1985, Walker and McComb 1988).

As a subtropical seagrass ecosystem, Shark Bay marks the northern boundary for the temperate A. antarctica and Posidonia spp. (Walker et al. 1988). As a result, the seagrass ecosystem is at particular risk from both acute and chronic high temperature stress. One such acute event occurred off the coast of Western Australia in the Austral summer of 2011 , when ocean temperatures rose $2-4^{\circ} \mathrm{C}$ above average for a two-month 
period (Wernberg et al. 2013). The 2011 marine heat wave was associated with almost record strength La Niña conditions and unusually strong poleward flow of the Leeuwin current, resulting in increased delivery of tropical water down the Western Australia coast; typically, monthly temperature anomalies within the Leuuwin Current region are less than $\pm 1.5^{\circ} \mathrm{C}$ during El Niño and La Niña years (Pearce and Feng 2013). Widespread changes in algae, fish and coral communities throughout Western Australia were associated with this heat wave (Pearce et al. 2011, Wernberg et al. 2013, Smale and Wernberg 2013, Pearce and Feng 2013). In Shark Bay, Following this heat wave, $A$. antarctica in Shark Bay experienced widespread declines in cover that exceeded $90 \%$ in many areas (Thomson et al. 2015, Fraser et al. 2014, Fig 1c,d, Fig 3b). A heat wave of this magnitude has not been recorded previously or since in Western Australian waters (Pearce and Fend 2013), and seagrass die-off of this magnitude has not been reported in Shark Bay before (Fig. 2).

\section{Sample collection and analysis}

In 2007, 475 monitoring locations were established throughout Shark Bay as part of a larger benthic survey (see Burkholder et al. 2013a for details). A subset of these sites were revisited after the 2011 heat wave to assess seagrass die-offs (Thomson et al. 2015) and medium-term seagrass status and recovery (this paper). Of the 475 original sites visited in 2007-2009, 63 were in a long-term study area (Heithaus et al. 2012) and were revisited four times between 2012-2014 to assess recovery and changes in the seagrass community. Sites occurred on three banks, which were blocked by microhabitat (deep channels generally 6-12m depth, shallow bank interiors $>2.5 \mathrm{~m}$ depth, 


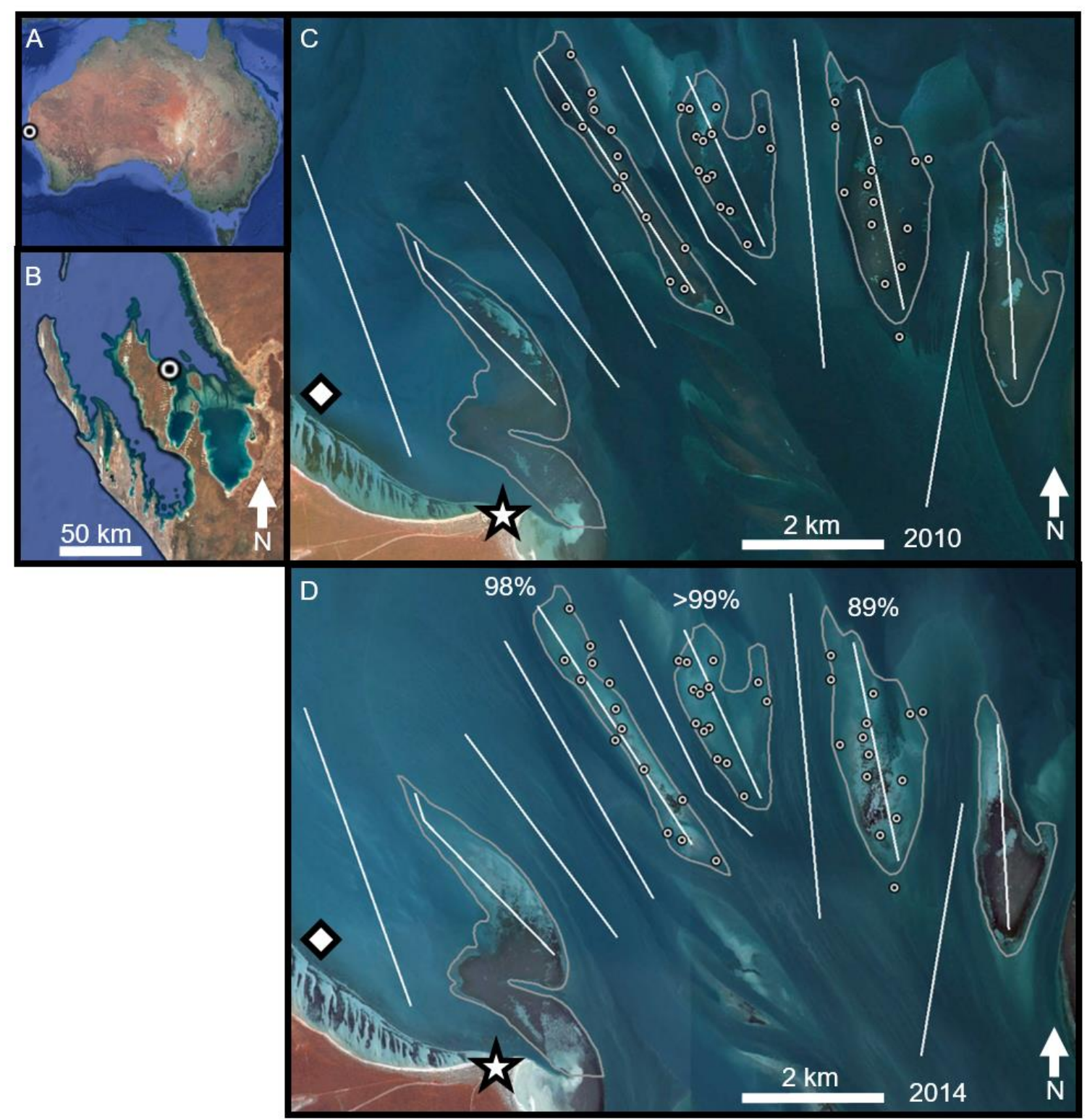

Figure 1. Location of study area within Australia (A) and the Eastern gulf of Shark Bay (B). Study area pre die-off (Mar. 2010, C) and post die-off (Oct. 2014, D) with estimates of seagrass loss (based on satellite imagery) for each focal bank. Seagrass sampling sites (circles), seagrass banks (gray outlines), water clarity transects (white lines), Monkey Mia (star), and the temperature monitoring station (diamond) are also visible. Images obtained from Google Earth. 


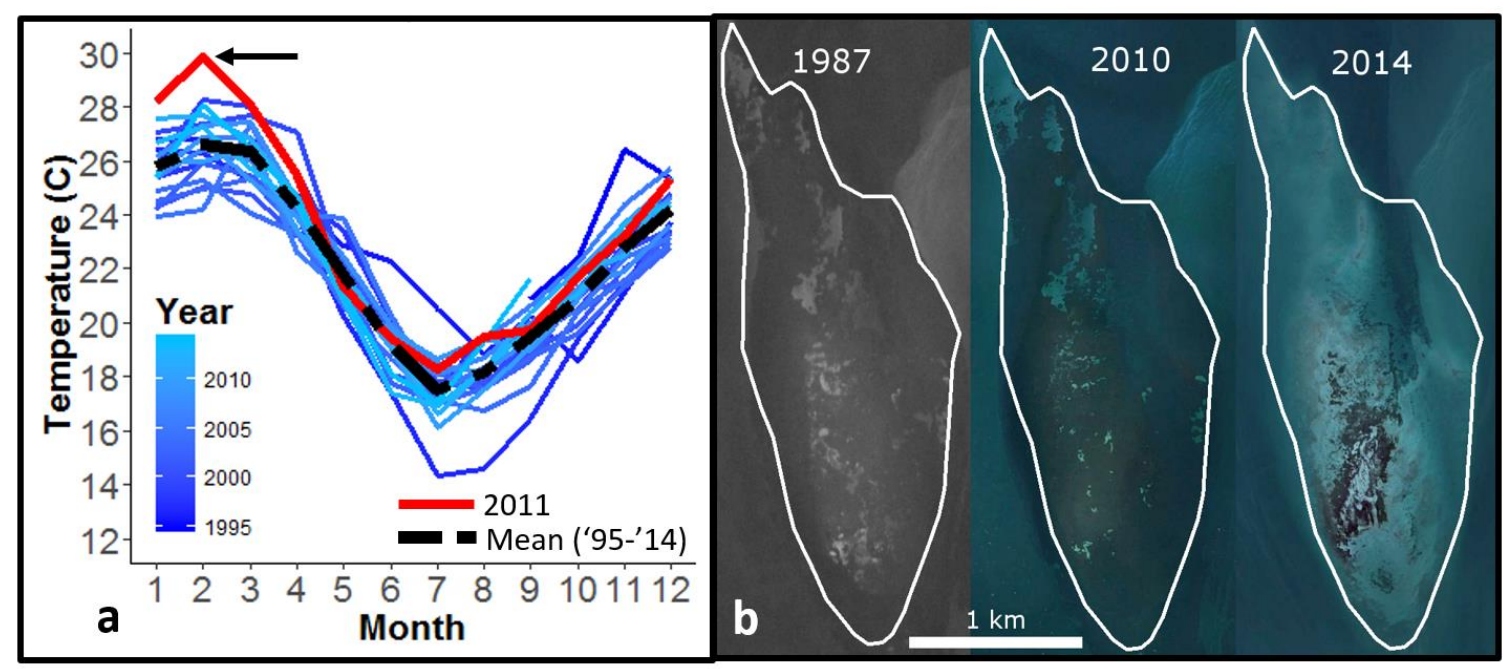

Figure 2. Long-term data illustrating the intensity of the 2011 heat wave and subsequent seagrass die-off. (a) Monthly (average) temperature data, collected every morning at a site immediately west of the study area. (b) Aerial imagery showing the magnitude of change in seagrass cover over decadal time-scales compared to change after the heat wave. Anecdotal accounts from local fishermen suggest no seagrass die-off of this magnitude has occurred in the study area in living memory (R. Nowicki pers. comm).

and bank edges 2.5-4.5m depth (Heithaus and Dill 2006). Site placement was randomized within each microhabitat for a total of seven sites in each microhabitat of three banks/channels. The twenty-one sites in deep channel habitats remained seagrassdepauperate in all surveys and were thus excluded from analysis, leaving 42 sites analyzed. Depth of retained sites ranged from $0.6 \mathrm{~m}$ to $7.3 \mathrm{~m}(\mu=2.8 \mathrm{~m}, s=1.1 \mathrm{~m})$. At each site, a $60 \mathrm{~cm} \times 60 \mathrm{~cm}$ quadrat was dropped from the research vessel and percent cover of seagrass (to species) was visually estimated by a diver using either snorkel or SCUBA. In 2013 and 2014, benthic macroalgae (all species pooled) were also quantified. The quadrat was then flipped end over end three times parallel to the heading of the boat, whereupon another quadrat measurement was taken; this process was repeated for a third 
quadrat and cover estimates were combined to generate a mean cover estimate at each site.

Sites were visited five times in 2007 (March, May, July, October, December), four times in 2008 (April, May, July, November), and once in 2009 (January) for a total of 10 pre die-off visits. These ten visits, six during the warm season (mid August-mid May) and four during the cold season (mid May- mid August), were pooled into a single “pre die-off” value for each site. Sites were visited four times after the die-off; October 2012 (warm), May 2013 (cold), October 2013 (warm), and August 2014 (cold).

Posidonia coriacea was rarely encountered and was pooled with the more common Posidonia australis, following established collection protocols (Burkholder et al. 2013a). Data were only analyzed for A. antarctica, Halodule uninervis, and benthic macroalgae; other species were rarely encountered (Table 1). For each species analyzed, percent occurrence (i.e., percent of sites where that species were present), mean cover when present (i.e., mean percent cover only including sites where that species was present), and mean cover overall (i.e., mean percent cover including all 42 sites) were recorded (Table 1). When considered together, these three metrics provide insight into not only the magnitude, but also the way in which seagrass cover changes. For example, loss of overall cover because of bed thinning results in reductions of mean cover when present, but little or no change in occurrence; conversely, patchy seagrass loss is characterized by little change in mean cover when present, but substantial reduction in occurrence.

In addition to seagrass surveys, changes in the biophysical environment (water temperature and clarity) were measured. Water temperature was collected daily at a 
long-term monitoring station situated in $4 \mathrm{~m}$ of water, $3 \mathrm{~km} \mathrm{NW}$ of Monkey Mia (Fig. 1c), from September 1995 to September 2014. Daily estimates were converted to monthly averages (Fig. 2a). Water clarity was measured within the study area indirectly using transect surveys for air-breathing fauna that were established in deep habitats $(\mathrm{n}=6)$ or shallow seagrass banks ( $\mathrm{n}=5$ ) in 1997. Approximately four times monthly, transects were sampled to quantify densities of air breathing organisms; every time an animal was sighted, depth was recorded and bottom composition was observed from the surface (see Heithaus et al. 2012 for methodological details). Cover data were converted to a binomial variable ( $1=$ bottom visible, $0=$ bottom not visible) for analysis. Because transect surveys only occurred under calm conditions (Beaufort scale $\leq 3$ ), wind conditions are unlikely to drive the observed patterns of bottom visibility. Because of variability in the way null results were recorded prior to 2008, only data from 2008-2014 were included for visibility analysis. Transects run between November and January were also excluded because of generally low sampling effort during these months, and transects run during 2011 were excluded to allow for clear separation of time periods.

\section{Statistical analyses}

All statistical analyses were performed in R v.3.2 (R core team 2015). Cover data were only analyzed for A. antarctica, Halodule uninervis, and benthic macroalgae because other species were rarely encountered (Table 1). Quade's tests were performed on mean cover data for all 42 sites for each visit (2007-2009 pooled, one visit in 2012, two in 2013, one in 2014) to assess significant differences in cover over time for both $A$. antarctica and benthic macroalgae. In each case, after the main test, post-hoc pairwise 
Table 1. Percent occurrence (i.e., percent of visits where that species were present), mean cover when present (i.e., mean percent cover only including sites where that species was present), and mean cover overall (i.e., mean percent cover including all 42 sites) of seagrass and macroalgae in this study. Values are presented with standard error when applicable. Data include bank and bank edge sites only ( $\mathrm{n}=42$ sites); data from the two visits in 2013 are pooled.

\begin{tabular}{|c|c|c|c|c|c|c|c|c|c|c|c|c|}
\hline \multirow[b]{2}{*}{ Species } & \multicolumn{4}{|c|}{$\%$ occurrence } & \multicolumn{4}{|c|}{ mean cover (when present) } & \multicolumn{4}{|c|}{ mean cover (all sites) } \\
\hline & $\begin{array}{r}2007- \\
2009 \\
\end{array}$ & 2012 & 2013 & 2014 & $\begin{array}{l}2007- \\
2009 \\
\end{array}$ & 2012 & 2013 & 2014 & $\begin{array}{c}2007- \\
2009 \\
\end{array}$ & 2012 & 2013 & 2014 \\
\hline $\begin{array}{l}\text { Amphibolis } \\
\text { antarctica }\end{array}$ & $83 \%$ & $64 \%$ & $62 \%$ & $55 \%$ & $90 \pm 1 \%$ & $5 \pm 1 \%$ & $6 \pm 1 \%$ & $4 \pm 1 \%$ & $76 \pm 2 \%$ & $3 \pm 1 \%$ & $4 \pm 1 \%$ & $2 \pm 1 \%$ \\
\hline Posidonia spp. & $10 \%$ & $7 \%$ & $7 \%$ & $5 \%$ & $40 \pm 6 \%$ & $5 \pm 5 \%$ & $13 \pm 7 \%$ & $8 \pm 3 \%$ & $3 \pm 1 \%$ & $<1 \%$ & $1 \pm 1 \%$ & $<1 \%$ \\
\hline $\begin{array}{l}\text { Halodule } \\
\text { uninervis }\end{array}$ & $12 \%$ & $2 \%$ & $12 \%$ & $29 \%$ & $3 \pm 1 \%$ & $1 \%$ & $8 \pm 6 \%$ & $9 \pm 3 \%$ & $<1 \%$ & $<1 \%$ & $1 \pm 1 \%$ & $2 \pm 1 \%$ \\
\hline $\begin{array}{l}\text { Halophila } \\
\text { ovalis }\end{array}$ & $2 \%$ & $2 \%$ & $2 \%$ & $0 \%$ & $3 \pm 1 \%$ & $1 \%$ & $1 \pm 1 \%$ & - & $<1 \%$ & $<1 \%$ & $<1 \%$ & - \\
\hline $\begin{array}{l}\text { Halopila } \\
\text { spinulosa }\end{array}$ & $2 \%$ & $0 \%$ & $0 \%$ & $2 \%$ & $24 \pm 9 \%$ & - & - & $<1 \%$ & $<1 \%$ & - & - & $<1 \%$ \\
\hline $\begin{array}{l}\text { Cymodocea } \\
\text { angustata }\end{array}$ & $7 \%$ & $10 \%$ & $7 \%$ & $5 \%$ & $8 \pm 1 \%$ & $4 \pm 2 \%$ & $6 \pm 2 \%$ & $2 \pm 1 \%$ & $<1 \%$ & $<1 \%$ & $<1 \%$ & $<1 \%$ \\
\hline $\begin{array}{c}\text { Benthic } \\
\text { macroalgae }\end{array}$ & NA & $71 \%$ & $48 \%$ & $62 \%$ & NA & $14 \pm 3 \%$ & $10 \pm 3 \%$ & $3 \pm 1 \%$ & NA & $10 \pm 2$ & $5 \pm 2 \%$ & $2 \pm 1 \%$ \\
\hline
\end{tabular}

comparisons were performed using pairwise Quade tests with a t-distribution and a Holm correction for multiple comparisons (Holm 1979) in the PMCMR package (Pohlert 2014). Because $H$. uninervis was rare in most years, cover estimates were zero-inflated and cover comparisons such as those performed for A. antarctica and benthic macroalgae were not possible between all visits. Therefore, $H$. uninervis presence was converted to a binomial variable and was modelled using a generalized linear mixed model (GLMM) to detect changes in the probability of encountering $H$. uninervis (presence/absence) at sites in the study area from 2012 to 2014 . As such, the H. uninervis model was run as a logistic regression using the "glmmPQL" function in the MASS package (Venables and Ripley 2002). The H. uninervis model included season (warm, cool) and visit number (1- 
4) as discrete fixed effects. Sampling site was included as a random effect to account for repeated visits.

Water visibility analysis

As in the H.uninervis model, bottom visibility was converted to a binomial variable ( $1=$ visible, $0=$ not visible) and modelled using a logistic regression with the glmmPQL function. Because deep transects were too deep to regularly see the bottom in either time period (see results), only data from shallow transects were included in the model. Fixed effects in the visibility model were depth, time period, and their interaction; transect identity was included as a random effect in the model to account for repeated visits to each transect. For all models and tests, effects were considered significant at the $\mathrm{p}=0.05$ level. If a significant interaction was present, main effects were not interpreted directly (Sokal and Rohlf 1995).

\section{Results}

Seven species of seagrass were encountered in surveys of shallow and edge sites from 2012 to 2014 (Table 1). Amphibolis antarctica was the only seagrass commonly encountered after the die-off, but at much reduced cover than before the heat wave (Table 1, Fig 4a); indeed, while occurrence decreased from $83 \%$ pre die-off to $\sim 60 \%$ post dieoff, declines in cover were largely driven by dramatic thinning of remaining seagrasses, as evidenced by large reductions in "cover when present" (Table 1, Fig. 3a,b, Fig 4a). Though low, A. antarctica cover varied significantly among the four post die-off visits $\left(F_{3,123}=2.95, p=0.035\right.$, Fig $\left.4 a\right)$. The decline was driven by differences between the second visit in April 2013 and the final (fourth) visit in August $2014\left(\mathrm{t}_{123}=-2.696\right.$, 
adjusted $\mathrm{p}=0.024$, Quade multiple comparison test); visits in October 2012, October 2013 and August 2014 were not significantly different from one another Widespread blackening and mortality of A. antarctica rhizomes was observed in 2013 (Fig. 3b, c), eventually resulting in the breakup of beds and transition to bare sand in many habitats by 2014 (Fig. 1d, 3d).

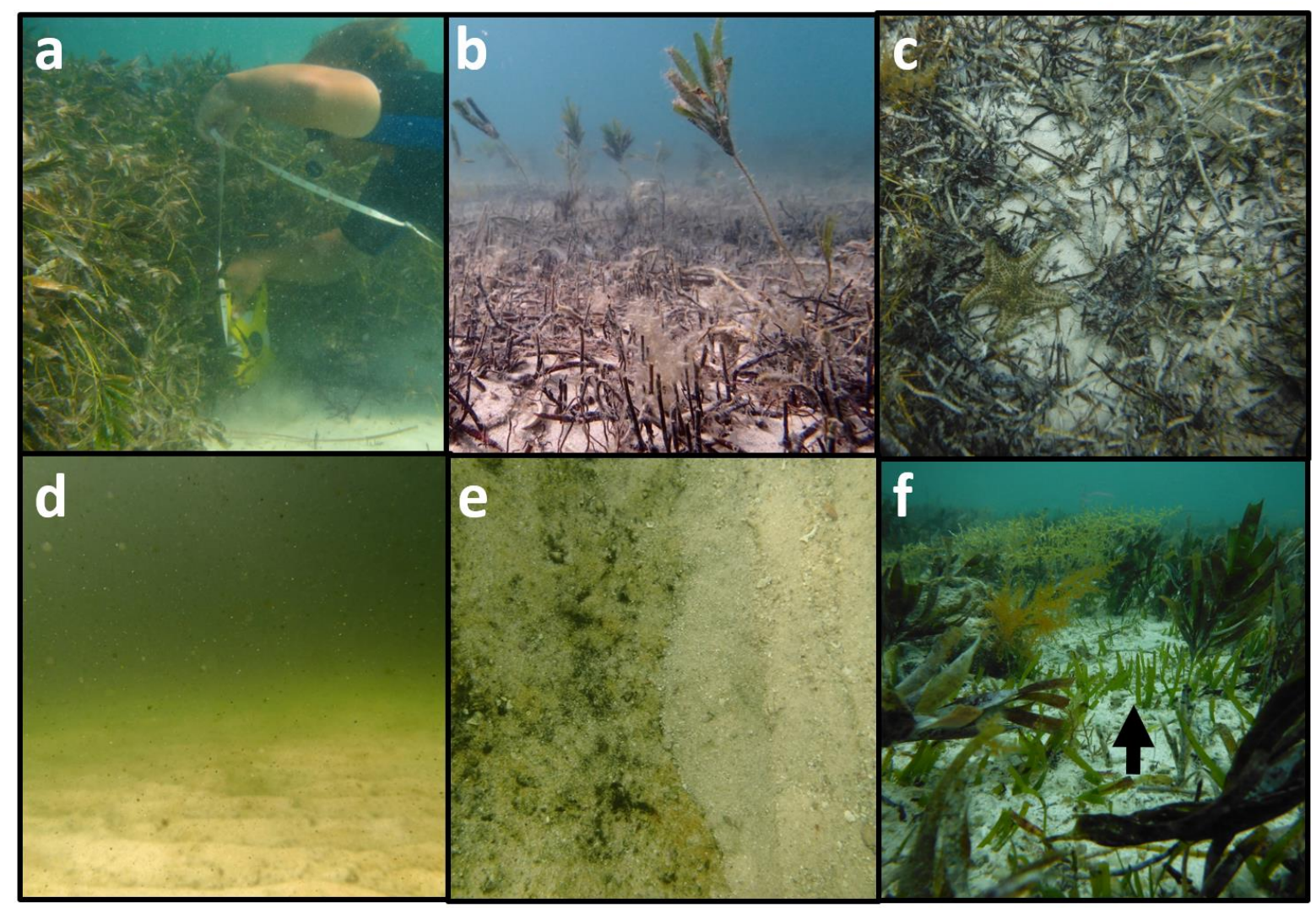

Figure 3. States of $A$. antarctica beds before and after seagrass die-off. A. antarctica bed before the heat wave and die-off (a). A formerly dense canopy (b) and rhizome mats, now disintegrating (c), photographed in 2013. Water column (d) and benthos (e, left side) during a phytoplankton bloom observed in 2014. Mixed seagrass community of temperate A. antarctica and tropical Halodule uninervis (f, black arrow) that has become increasingly common since 2011. Images: SBERP. 

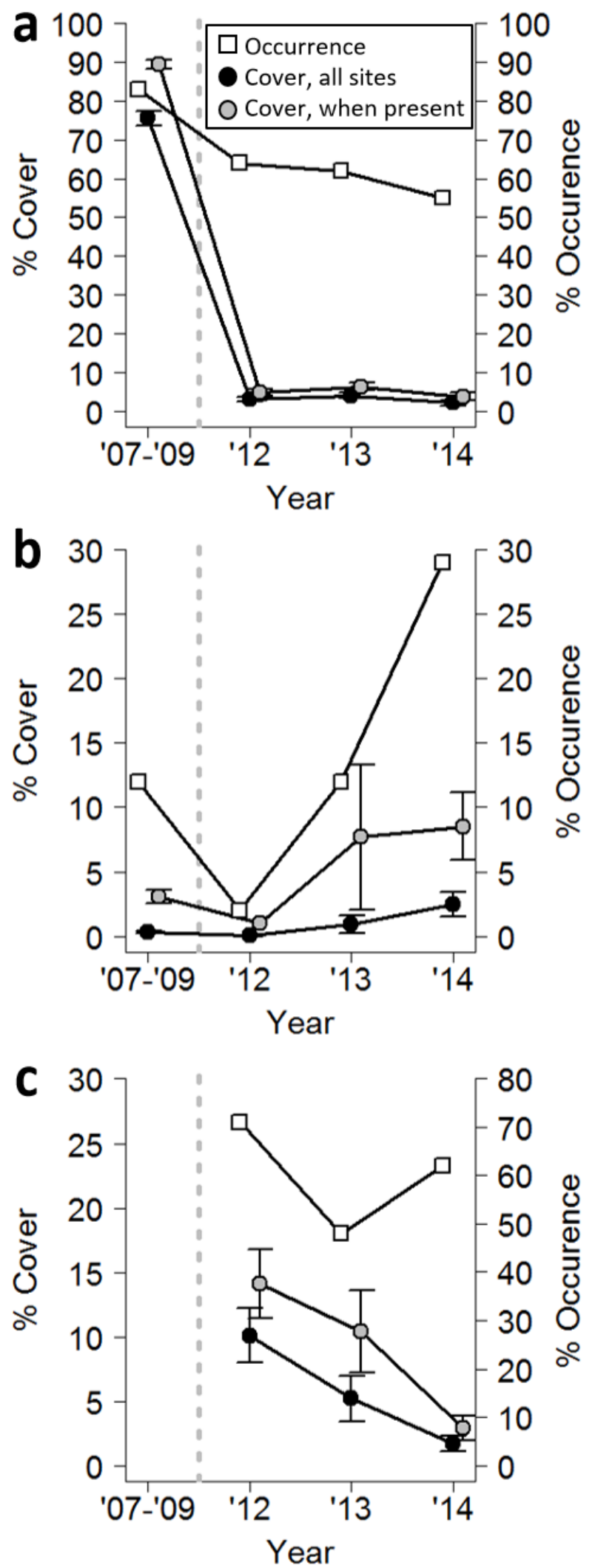

Figure 4. Change in mean occurrence, mean cover when present, and total mean cover for the three dominant macrophytes in Shark Bay following the heat wave- (a) Amphibolis antarctica, (b) Halodule uninervis, and (c) benthic macroalgae. Pre die-off values (left of dotted line) are provided when available for comparison. Data from the two visits in 2013 are pooled for consistency with table 1. Note different scale of $\mathrm{Y}$ axes in different graphs. Error bars $=$ s.e. 
The only seagrass species that showed significant evidence of expansion after the die-off was Halodule uninervis. The logistic regression model indicated an increased probability of encountering $H$. uninervis with time $\left(\mathrm{t}_{124}=6.94, \mathrm{p}<0.0001\right)$ but not by cold or warm season $\left(\mathrm{t}_{124}=0.28, \mathrm{p}=0.78\right)$. The occurrence of $H$. uninervis increased from $2 \%$ of visits in 2012 to $29 \%$ of visits by 2014 ; additionally, there were increases in the percent cover of $H$. uninervis at sites where it was present (Table 1, Figs 3f, 4b). Other seagrass species (Posidonia spp., Halophila ovalis, Halophila spinulosa, and Cymodocea angustata) were rarely encountered (Table 1).

Macroalgae cover

Though macroalgae cover was not quantified before 2012, several lines of evidence indicate it was at most a minor contributor to submerged aquatic vegetation (SAV) cover in the past. Firstly, A. antarctica dominates cover surveys from 2007-2009, leaving little room for substantial coverage by other SAV. Secondly, analysis of $A$. antarctica habitats by animal borne video cameras attached to green turtles before the heat wave (1999-2003) indicate that benthic macroalgae were historically a very minor cover component in the study system — becoming common only after the seagrass die-off (Thomson et al. 2014). Finally, benthic macroalgae was rarely encountered by divers as a substantial component of SAV in the study area prior to the heat wave (D. Burkholder and J. Thomson, pers. obs). Macroalgae was common but sparse after the die-off, as occurrence was high but cover when present was low (Table 1, Fig 4c). Mean overall cover of benthic macroalgae declined over time $\left(\mathrm{F}_{2,82}=17.17, \mathrm{p}<0.0001\right)$; percent cover in $2012(10 \%)$ was significantly higher than in $2013\left(5.2 \%, \mathrm{t}_{82}=-3.692\right.$, adjusted $\mathrm{p}=$ 
$0.0002)$ or $2014\left(1.7 \%, \mathrm{t}_{82}=-5.253, \mathrm{p}<0.0001\right.$, respectively, Table 1). Algal cover did not differ between 2013 and 2014 (Table 1, Fig 4c).

\section{Biophysical factors}

Monthly average temperatures indicate that the extreme heat wave of 2011 has not been repeated (Fig. 2a). Water clarity, however, has decreased since 2011; the probability of being able to see bottom on shallow transects was significantly influenced by the interaction of depth and time period $\left(\mathrm{t}_{3738}=2.41, \mathrm{p}=0.016\right.$, Table 2$)$. The percentage of spot surveys on shallow transects in which bottom was observable declined from $97.6 \%$ pre die-off (1463 of 1499 surveys) to $68.4 \%$ post die-off (1540 of 2251 visits), while the percentage of surveys in which bottom as observed in deep habitats remained very low in both time periods (2.0 and 1.3\%, Table 3$)$. On average, the depth at which there is a $50 \%$ probability of seeing the bottom was reduced by approximately $3.2 \mathrm{~m}$ (Fig. 5).

In addition to chronic reductions in water clarity following the seagrass die-off, a widespread and intense phytoplankton bloom was observed in both gulfs of Shark Bay from February to April 2014, potentially facilitated by sustained high February water temperatures of $28^{\circ} \mathrm{C}\left(2.3^{\circ} \mathrm{C}\right.$ above the February average and the second warmest February after 2011 in at least 20 years, Fig 2a) and the mass release of nutrients from abundant decaying seagrass tissue (Dave Holley, Department of Parks and Wildlife WA, pers. comm). The bloom was associated with a substantial increase in light attenuation for several weeks (e.g., Fig 3b v.s. Fig 3d, Department of Parks and Wildlife, pers. comm), as well as a uniform coating of plankton on the benthos (Fig. 3e). 
Table 2. Logistic model results on the impact of depth, time period, and their interaction on probability of being able to tell bottom cover on shallow seagrass banks. Transect identity was included as a random effect to account for repeated visits on each transect.

\begin{tabular}{lccccc}
\hline \multicolumn{1}{c}{ Factor } & coefficient & std.err & DF & t value & P \\
\hline time period & 2.00 & 0.52 & 3738 & 3.81 & $<0.001$ \\
Depth & -1.35 & 0.08 & 3738 & 17.77 & $<0.0001$ \\
time period : depth & 0.38 & 0.16 & 3738 & 2.41 & 0.016 \\
\hline
\end{tabular}

Table 3. Number of spot surveys conducted and number of surveys in which bottom was visible from the surface for deep and shallow habitats before and after the seagrass dieoff.

\begin{tabular}{ccccc}
\hline time period & habitat & $\begin{array}{c}\text { bottom surveys } \\
(\mathbf{n})\end{array}$ & $\begin{array}{c}\text { bottom } \\
\text { sightings (n) }\end{array}$ & $\begin{array}{c}\text { Probability of } \\
\text { sighting bottom }\end{array}$ \\
\hline \multirow{2}{*}{$2008-2010$} & shallow & 1499 & 1463 & 0.976 \\
& deep & 1024 & 20 & 0.02 \\
\hline \multirow{2}{*}{$2012-2014$} & shallow & 2251 & 1540 & 0.684 \\
& deep & 1199 & 16 & 0.013 \\
\hline
\end{tabular}

\section{Discussion}

My results indicate that over medium time scales ( $\sim 3$ years) following an extreme climactic event, significant recovery of the previously dominant temperate seagrass Amphibolis antarctica has not occurred in Shark Bay. Similarly, though macroalgae can exhibit rapid growth rates and outcompete seagrasses (McGlathery 2001), benthic macroalgae cover declined significantly between 2012 and 2014, indicating a shift from seagrass to macroalgae dominance is unlikely in the study system. Instead, despite an initial decline likely resulting from smothering by dead A. antarctica (Thomson et al. 2015), the tropical early successional seagrass Halodule uninervis has expanded following the marine heat wave. The observed expansion of $H$. uninervis is generally consistent with its life history charactaristics, which includes rapid rates of rhizome expansion and a dormant seed bank, something which A. antarctica lacks (Larkum et al. 


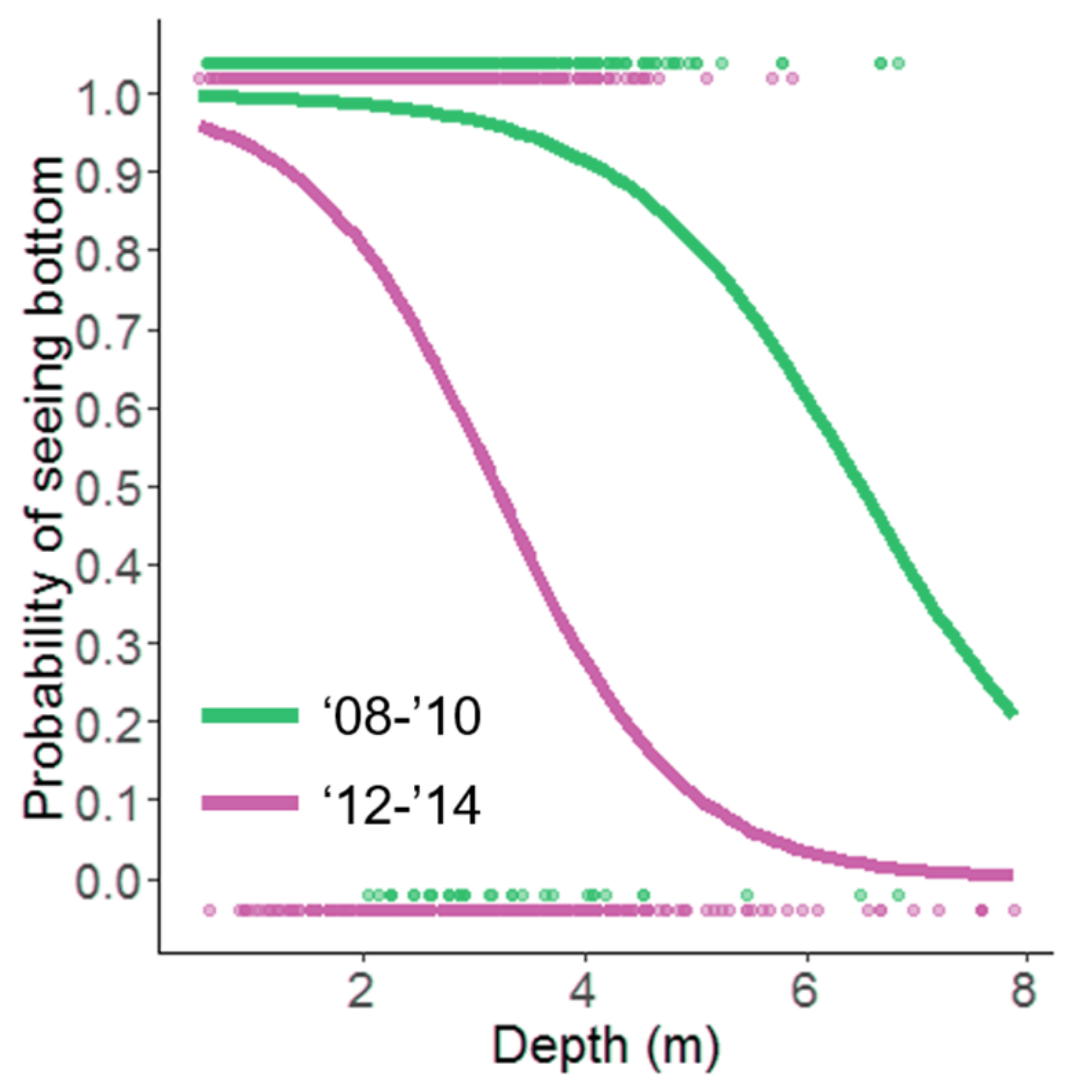

Figure 5. Logistic regression illustrating significantly reduced water clarity $(p=0.016)$ after the seagrass die-off. Points and regressions intentionally jittered on Y axis.

2006, Orth et al. 2007). Indeed, patterns of H. uninervis expansion described here follow patterns seen in other mixed-Halodule spp. systems subject to disturbance, such as $H$. uninervis in Malaysia (Short et al. 2014) and Halodule wrightii in seagrass beds in Florida Bay usually dominated by Thalassia testudinum or Syringodium filiforme (Robblee et al. 1991, Fouqurean and Robblee 1999, Peterson et al. 2002). The lack of recovery of $A$. antarctica, a late-successional species, reflects the post-disturbance behavior of some (but not all) seagrass ecosystems dominated by late-successional seagrasses (see below). A significant and sustained reduction in water clarity in the years 
following the seagrass-die off is consistent with a loss of sediment stabilization, an ecosystem function characteristic of intact seagrass beds (Carr et al. 2010, Van der Heide et al. 2011). Additionally, the occurrence of a widespread phytoplankton bloom in 2014 is consistent with blooms observed elsewhere following widespread seagrass declines (e.g., Fourqurean and Robblee 1999). Such changes to the biophysical environment, along with seagrass species features (e.g., life-history characteristics) and biological features (e.g., connectivity, community trophic structure, Unsworth et al. 2015) have the potential to restrict or inhibit a return to an A. antarctica dominated ecosystem and impact the resilience of this system. The observed shift in the seagrass community has ecological implications not only for biophysical features, but also for seagrass-associated fauna.

Rapid recovery of Amphibolis spp. in other systems

Though the traits common in late successional seagrasses generally do not favor rapid vegetative expansion or robust reproductive resilience to widespread seagrass loss, rapid recovery of Amphibolis spp. is possible if either of the resilience mechanisms mentioned previously (regeneration from rhizomes or recruitment from nearby beds) are successful. For example, Amphibolis antarctica near the Wooramel delta in Shark Bay (east of this study site) began to refoliate two years after the die-off, but at significant cost to belowground energy stores (Fraser et al. 2014, Thomson et al. 2015). On Success Bank, Western Australia, the congener Amphibolis griffithi is recorded as expanding rapidly $\left(17.6\right.$ ha year $^{-1}$ ) partially because of reproduction and gap infilling from nearby beds (Walker et al. 2006). Similarly, in South Australia, a restoration project which 
provided anchoring points in close proximity $(<80 \mathrm{~m})$ to mature $A$. antarctica beds resulted in the establishment of new beds with similar structural characteristics to mature beds within three years (Tanner 2015). Importantly, until below-ground biomass stocks are replenished by photosynthesis from above-ground tissues, merely measuring aboveground biomass of recovering beds may overestimate ecological resilience to future disturbance because the below-ground biomass responsible for resilience is reduced, either because it was spent on rapid recovery or because new recruits have not yet established substantial below-ground stores.

\section{Potential mechanisms of rapid recovery}

Though the resilience strategies of $A$. antarctica allow for rapid recovery of above-ground biomass in some cases (e.g., Walker et al. 2006, Fraser et al. 2014), no such recovery occurred in this study. Pairwise comparisons indicate that $A$. antarctica cover was slightly (3.3\%) but significantly higher in April 2013 (second visit) than it was in 2014 (fourth visit), potentially signifying an attempt to use below-ground energy stores to re-foliate, as was observed on the Wooramel Delta (Fraser et al. 2014). However, the capability of A. antarctica meadows within the study system to recover in this manner is limited, because the widespread observed death of $A$. antarcticas's rhizome layer in this study (Fig. 3b,c, see also Thomson et al. 2015) has resulted in large areas of bare sand with no below-ground biomass from which to regenerate. The loss of rhizomes also resulted in loss of suitable substratum for macroalgae, likely acting as a strong driver of the continued decline in macroalgae cover. Unlike Success Bank, the magnitude of the initial die-off destroyed or damaged entire seagrass banks (Fig. 1d, 2b), increasing the 
distance between surviving shoots and potentially inhibiting reproductive capacity through mechanisms such as pollen limitation (e.g., van Tussenbroek et al. 2016). Though formal surveying of $A$. antarctica propagules, seedlings and reproductive structures were outside scope of this work, signs of sexual reproduction were not observed between 2012-2015 (pers. obs). Importantly, unlike other biophysical feedback loops (i.e., turbidity) which may become less severe if environmental conditions improve, reproductive Allee affects will remain unless plant density itself is restored (van Tussenbroek et al. 2016). Such density dependence may strengthen continued divergence in post-disturbance cover of A. antarctica and Halodule uninervis, as the seed bank of the latter allows for the establishment of widespread new beds, facilitating future reproductive success.

Because the resilience mechanisms that would allow for rapid recovery of $A$. antarctica have failed, vegetative expansion from remaining shoots may now be the most likely mechanism of recovery. Like many late successional seagrasses, A. antarctica has slow rhizome elongation rates $\left(20 \mathrm{~cm} \mathrm{yr}^{-1}\right)$ - one fifth that of $H$. uninervis (Marba and Duarte et al. 1998). As a result, the return time of A. antarctica will likely be considerable, increasing the likelihood that future climate extreme events will occur in this system before recovery is complete. Additionally, weak recovery rates may allow biophysical and biological features of the environment (sensu Unsworth et al. 2015) to play critical roles in determining whether a meaningful recovery of $A$. antarctica will occur in this system at all. 


\section{Biophysical factors influencing recovery}

In addition to seagrass traits, biophysical features of the environment, such as water clarity and climate stability may be particularly critical to mediating the recovery trajectory of seagrasses in Shark Bay. While common anthropogenic alterations to biophysical features, such as eutrophication, are largely absent in Shark Bay, density dependent biophysical processes, plankton blooms, and future heat waves may all be important to shaping recovery trajectories for this system. Seagrasses have high light requirements (Walker and McComb 1992, Dennison et al. 1993) and are well known for their density-dependent capability to trap sediment and increase water clarity. These processes generate positive feedbacks that facilitate seagrass expansion at high seagrass densities, but as seagrass is lost, turbidity increases and light limitation can inhibit the recovery of damaged beds (Van der Heide et al. 2007, Carr et al. 2010). In Shark Bay, areas with reduced water clarity appeared to suffer greater declines in response to the initial disturbance (Thomson et al. 2015, Fraser et al. 2014), and water clarity in the study system was significantly reduced in the years following the seagrass die-off (Tables 2,3, Fig 5) - suggesting that water clarity reductions may be a strong inhibitor to seagrass recovery in this system. In addition to resulting in a loss of sediment stabilization potential, seagrass losses can also result in nutrient export to the water column, triggering phytoplankton blooms that reduce water clarity. For example, plankton blooms resulting from an extreme climactic event and subsequent seagrass die-off in Florida Bay impacted the local light environment for close to a decade following the initial event, and may have contributed to subsequent seagrass die-offs (Robblee et al 1991, Fourqurean and Robblee 1999). The significant reduction in water clarity following the seagrass die-off and 
observed widespread phytoplankton bloom in Shark Bay (despite minimal nutrient runoff) demonstrates the importance of biophysical features of post-disturbance seagrass ecosystems, even when local anthropogenic impacts to water clarity are minimal.

The role of future climate events is also likely to play an increasingly important role in recovery trajectories of disturbed seagrass ecosystems as extreme El Niño and La Niña events become more frequent (Cai et al. 2014, 2015). However, vulnerability to extreme warm events is not spatially homogenous: regions characterized by tropical boundary currents (such as Western Australia) are projected to warm two to three times faster than the oceanic average (Wu et al. 2012, Vergés et al. 2014). Furthermore, areas where dominant seagrasses are near their temperature thresholds- such as Shark Bay, which sits in a climate transition zone between temperate and tropical regimes- are more likely to be inhibited by future acute and chronic warming (Unsworth et al. 2015). Such subtropical regions may be particularly vulnerable to community shifts towards

dominance by fast-growing tropical seagrasses because they host a mixed assemblage of temperate late successional and tropical early successional species. Understanding the resilience of late successional seagrasses to climate extremes via resistance, return time, and the mechanisms responsible for each will be critical to determining where and when these foundation species will persist.

\section{Biological factors influencing recovery}

Alteration of biological features such as top-down control can also be an important driver of return time following disturbance (Unsworth et al. 2015). While historically underappreciated, top-down control by herbivores (and indirectly by their 
predators) can structure seagrass ecosystems through both facultative and destructive pathways (Chapter II). Previous work in Shark Bay has shown that top-down control by herbivores and their predators influences seagrass communities (Burkholder et al. 2013) - though whether the influence of top down control will change is unclear. Generally, the importance of top down control may be high in recovering seagrass ecosystems as herbivores struggle to meet metabolic demands and newly disturbed seagrasses invest in regrowth and regeneration (e.g., Fraser et al. 2014). The ultimate effect of such herbivory on seagrass return time, however, will depend an interaction between biological features of herbivores (herbivore density, feeding preferences, and feeding tactics) and those of seagrass (nutrient content, grazing tolerance, grazing recovery speed). For example, while tropical early successional seagrasses are often more palatable to (and preferred by) herbivores than late-successional species (Burkholder et al. 2012, Preen 1995, Armitage and Fouqurean 2006, Bourque and Fourqurean 2013, Chapter II), the former can also recover quickly from grazing (e.g., Preen 1995). In Shark Bay, food preference experiments indicate that $H$. uninervis is grazed at higher rates and more often than either A. antarctica or $P$. australis (both late successional seagrasses, Burkholder et al. 2012). However, an increase in prevalence of mixed beds of preferred tropical seagrasses and recovering temperate seagrasses may still impact the recovery of A. antarctica, especially if herbivores employ indiscriminate destructive feeding strategies like grazing fronts by sea urchins or excavation foraging by dugongs (e.g., Peterson et al. 2002, Preen 1995).

In addition to being altered by consumers, return times of $A$. antarctica could also be altered by $H$. uninervis itself. It is possible that expansion of $H$. uninervis may 
provide some ecosystem functions that could facilitate the regrowth of A. antarctica, such as sediment stabilization, (Fonesca 1985) or providing of substrate for attachment for the barbs of $A$. antarctica seedlings (Turner 1983). However, the small size of $H$. uninervis shoots suggests the potential magnitude of such facilitation is likely to be minor.

\section{Ecological implications of extended return time}

Complete loss of foundation species has clear implications for ecosystem recovery and community functions. However, multi-species foundation species assemblages can generate more nuanced responses via disturbance-induced changes in assemblage composition. These shifts, which may be driven proximally by differences in return time or environmental tolerance and ultimately by life history traits and ecosystem features, can result in changes to ecosystem function even when seagrass abundance per se has recovered. For Shark Bay, the expansion of H. uninervis, even if continued, does not indicate a functional recovery. A. antarctica exceeds the size, standing stock, and productivity of $H$. uninervis by one to several orders of magnitude (Walker 1985, Walker et al. 1988). As such, H. uninervis is unlikely to be able to provide the same magnitude of ecosystem function as the much larger $A$. antarctica, such as the generation of large, structurally complex habitat (Borowitzka et al. 2006) or large amounts of primary production (Walker et al. 1985) provision of food through facilitation of epiphytes (Borowitzka et al. 2006), sediment accumulation (Fonseca and Fisher 1986), or carbon storage (Fourqurean et al. 2012).

While some functional losses (such as loss of primary production) may be relatively straightforward to calculate, the ecological implications for consumers can be 
particularly complex and difficult to predict. For example, seagrass loss will almost certainly reduce food supplies for species that directly feed on seagrass or its epiphyte community, but may result in a temporary prey pulse for predators that consume animals that use seagrass as refuge. Similarly, resource loss can result in either expansion or restriction of species' trophic niche (Jones and Post 2016), which may lead to trophic restructuring and changes in pathways of top-down control. In Shark Bay, expansions of H. uninervis and losses of $A$. antarctica and associated epiphytes will likely lead to important shifts in the resource base of the food web. Feeding preference experiments in Shark Bay suggest that, when available, tropical seagrasses like $H$. uninervis are preferred to A. antarctica as a food source (Burkholder et al. 2012), suggesting they are higher quality forage. Similarly, macroalgae appears to be an important component of the diet of green turtles (Chelonia mydas) and the dominant seagrass associated teleost, the western striped trumpeter (Pelates octolineatus) (Burkholder et al. 2011, Bessey and Heithaus 2015). Exploitation of these resources may be keeping standing biomass low, even if production is high.

In addition to changes in the trophic structure, shifts in community composition may also alter patterns of residency, movement, or behavior as animals deal with a changing seascape of food availability, food quality, refuge, and predation risk. While investigations into the effects of seagrass die-offs on specific seagrass associated fauna are not uncommon, relatively little is known about whether or how such declines alter species interactions and community structure in general- an important gap given the magnitude of global seagrass loss and the importance of species interactions to structuring ecosystems. 
The work presented here, combined with the slow rhizome elongation rates (Marba and Duarte 1998), loss of sediment stabilization potential, and thermal vulnerability (Walker and Cambridge 1995) of A. antartcica, suggests that Shark Bay's mixed seagrass community is changing to reflect a shift to tropical seagrass, and that a return to a state dominated by A. antarctica is likely to be lengthy if it occurs at all. During this time, $A$. antarctica is likely to be vulnerable to subsequent disturbance from future climactic extremes, changes in biophysical features, and alteration of biological features such as top-down control. More generally, this work suggests that predicting the recovery trajectory of seagrass ecosystems based only on initial magnitude of decline may be difficult, especially in mixed-species beds where life history strategies and mechanisms of recovery differ. Knowledge of the life history of the species of interest (particularly likely mechanisms of recovery) and repeated post-disturbance monitoring is necessary to assess whether such recovery mechanisms are successful in facilitating recovery. Integration of studies such as this into a general framework for resilience will be vital to predicting how vulnerable marine communities (and the functions they provide) will change in the context of climate change.

Acknowledgements: Thanks to R. Sarabia, J. Olson, A. Macy, A. Morgan, K. Gastrich, J. Johnson, N. Norton, M. Jew, T. Code, C. Morgan, and H. Neutzel for aid in data collection. I would also like to thank the Staff of Monkey Mia Dolphin Resort and Dave Holley at Department of Parks and Wildlife WA for considerable logistical support, and Blue Lagoon Pearls for access to their temperature records. RJN was supported by NSF 
GRF No. DGE-1038321. Research support was provided by NSF grants OCE0745606 and OCE1329408. Special thanks to R. Sarabia, D. Churchill, and C. Cáceres for reviewing earlier versions of the manuscript. This is contribution No. XXX to the Shark Bay Ecosystem Research Project and No. XXX to the Marine Education and Research Initiative of the Institute for Water and the Environment at FIU.

\section{Literature Cited}

Armitage AR, Fourqurean JW (2006) The short-term influence of herbivory near patch reefs varies between seagrass species. Journal of Experimental Marine Biology and Ecology 339:65-74

Augspurger CK (2013) Reconstructing patterns of temperature, phenology, and frost damage over 124 years: Spring damage risk is increasing. Ecology 94:41-50

Bennett S, Wernberg T, Harvey ES, Santana-Garcon J, Saunders BJ (2015) Tropical herbivores provide resilience to a climate-mediated phase shift on temperate reefs. Ecology Letters 18:714-723

Bessey C, Heithaus MR (2015) Ecological niche of an abundant teleost, Pelates octolineatus, in a subtropical seagrass ecosystem. Mar Ecol Prog Ser 541:195-204

Borowitzka, M., Lavery, P. \& van Keulen, M. (2006). Chapter 19: Epiphytes of Seagrasses. In:Seagrasses: Biology, Ecology, and Conservation (eds. Larkum, A., Orth, R. \& Duarte, C.). Springer, Dordrecht, The Netherlands, pp. 441-461.

Bourque AS, Fourqurean JW (2013) Variability in herbivory in subtropical seagrass ecosystems and implications for seagrass transplanting. Journal of Experimental Marine Biology and Ecology 445:29-37

Burkholder DA, Fourqurean JW, Heithaus MR (2013) Spatial pattern in seagrass stoichiometry indicates both $\mathrm{N}$-limited and P-limited regions of an iconic P-limited subtropical bay. Marine Ecology Progress Series 472:101-115

Burkholder DA, Heithaus MR, Fourqurean JW (2012) Feeding preferences of herbivores in a relatively pristine subtropical seagrass ecosystem. Marine and Freshwater Research 63:1051-1058 
Burkholder DA, Heithaus MR, Fourqurean JW, Wirsing A, Dill LM (2013) Patterns of topdown control in a seagrass ecosystem: could a roving apex predator induce a behaviour-mediated trophic cascade? Journal of Animal Ecology 82:1192-1202

Burkholder DA, Heithaus MR, Thomson JA, Fourqurean JW (2011) Diversity in trophic interactions of green sea turtles Chelonia mydas on a relatively pristine coastal foraging ground. Marine Ecology Progress Series 439:277-293

Cai W, Borlace S, Lengaigne M, Van Rensch P, Collins M, Vecchi G, Timmermann A, Santoso A, McPhaden MJ, Wu L, England MH, Wang G, Guilyardi E, Jin, F. (2014) Increasing frequency of extreme El Niño events due to greenhouse warming. Nature Climate Change 4:111-116

Cai W, Wang G, Santoso A, McPhaden MJ, Wu L, Jin F-F, Timmermann A, Collins M, Vecchi G, Lengaigne M, England MH, Dommenget D, Takahashi K, Guilyardi E (2015) Increased frequency of extreme La Niña events under greenhouse warming. Nature Clim Change 5:132-137

Campbell SJ, McKenzie LJ (2004) Flood related loss and recovery of intertidal seagrass meadows in southern Queensland, Australia. Estuarine, Coastal and Shelf Science $60: 477-490$

Carpenter S, Walker B, Anderies JM, Abel N (2001) From metaphor to measurement: resilience of what to what? Ecosystems 4:765-781

Carr J, D'Odorico P, McGlathery K, Wiberg P (2010) Stability and bistability of seagrass ecosystems in shallow coastal lagoons: Role of feedbacks with sediment resuspension and light attenuation. Journal of Geophysical Research: Biogeosciences 115

Ciais P, Reichstein M, Viovy N, Granier A, Ogée J, Allard V, Aubinet M, Buchmann N, Bernhofer C, Carrara A, Chevallier F, De Noblet N, Friend AD, Friedlingstein P, Grünwald T, Heinesch B, Keronen P, Knohl A, Krinner G, Loustau D, Manca G, Matteucci G, Miglietta F, Ourcival JM, Papale D, Pilegaard K, Rambal S, Seufert G, Soussana JF, Sanz MJ, Schulze ED, Vesala T, Valentini R (2005) Europe-wide reduction in primary productivity caused by the heat and drought in 2003. Nature 437:529-533

Dai L, Korolev KS, Gore J (2015) Relation between stability and resilience determines the performance of early warning signals under different environmental drivers. Proceedings of the National Academy of Sciences 112:10056-10061

Dennison WC, Orth RJ, Moore KA, Stevenson JC, Carter V, Kollar S, Bergstrom PW, Batiuk RA (1993) Assessing water quality with submersed aquatic vegetation. BioScience 43:86-94 
Fonseca MS (1989) Sediment stabilization by Halophila decipiens in comparison to other seagrasses. Estuarine, Coastal and Shelf Science 29:501-507

Fonseca MS, Fisher JS (1986) A comparison of canopy friction and sediment movement between four species of seagrass with reference to their ecology and restoration. Marine Ecology Progress Series 29:15-22

Fourqurean JW, Duarte CM, Kennedy H, Marbà N, Holmer M, Mateo MA, Apostolaki ET, Kendrick GA, Krause-Jensen D, McGlathery KJ, others (2012) Seagrass ecosystems as a globally significant carbon stock. Nature Geoscience 5:505-509

Fourqurean JW, Robblee MB (1999) Florida Bay: A history of recent ecological changes. Estuaries 22:345-357

Fraser MW, Kendrick GA, Statton J, Hovey RK, Zavala-Perez A, Walker DI (2014) Extreme climate events lower resilience of foundation seagrass at edge of biogeographical range. Journal of Ecology 102:1528-1536

Glynn PW (1993) Coral reef bleaching: ecological perspectives. Coral reefs 12:1-17

Heide T van der, Nes EH van, Geerling GW, Smolders AJ, Bouma TJ, Katwijk MM van (2007) Positive feedbacks in seagrass ecosystems: implications for success in conservation and restoration. Ecosystems 10:1311-1322

Heithaus MR (2001) The biology of tiger sharks, Galeocerdo cuvier, in Shark Bay, Western Australia: sex ratio, size distribution, diet, and seasonal changes in catch rates. Environmental Biology of Fishes 61:25-36

Heithaus MR \& Dill L (2006) Does tiger shark predation risk influence foraging habitat use by bottlenose dolphins at multiple spatial scales? Oikos, 114: 257-264

Heithaus MR, Wirsing AJ, Dill LM (2012) The ecological importance of intact top-predator populations: a synthesis of 15 years of research in a seagrass ecosystem. Marine and Freshwater Research 63:1039-1050

Holling CS (1973) Resilience and stability of ecological systems. Annual review of ecology and systematics:1-23

Holm S (1979) A Simple Sequentially Rejective Multiple Test Procedure. Scandinavian Journal of Statistics 6:65-70

Honnay O, Verheyen K, Butaye J, Jacquemyn H, Bossuyt B, Hermy M (2002) Possible effects of habitat fragmentation and climate change on the range of forest plant species. Ecology Letters 5:525-530

Inouye DW (2008) Effects of Climate Change on Phenology, Frost Damage, and Floral Abundance of Montane Wildflowers. Ecology 89:353-362 
Jentsch A, Kreyling J, Beierkuhnlein C (2007) A new generation of climate-change experiments: events, not trends. Frontiers in Ecology and the Environment 5:365374

Jones CG, Lawton JH, Shachak M (1994) Organisms as ecosystem engineers. In: Ecosystem management. Springer, p 130-147

Jones AW, Post DM (2016) Does intraspecific competition promote variation? A test via synthesis. Ecol Evol 6:1646-1655

Larkum A, Orth R, Duarte C (Eds) (2006) Seagrasses: Biology, Ecology, and Conservation. Springer Netherlands, Dordrecht

Mantgem PJ van, Stephenson NL, Byrne JC, Daniels LD, Franklin JF, Fulé PZ, Harmon ME, Larson AJ, Smith JM, Taylor AH, Veblen TT (2009) Widespread Increase of Tree Mortality Rates in the Western United States. Science 323:521-524

Marba N, Duarte CM (1998) Rhizome elongation and seagrass clonal growth. Marine Ecology Progress Series 174

May RM (1973) Stability and Complexity in Model Ecosystems. Princeton University Press.

McGlathery KJ (2001) Macroalgal blooms contribute to the decline of seagrass in nutrientenriched coastal waters. Journal of Phycology 37:453-456

Nowicki RJ, Fourqurean JW, Heithaus MR (in press) The role of consumers in structuring seagrass communities: direct and indirect mechanisms. In: Larkum A, Kendrick GA (eds) Biology of seagrasses. Springer

Orth RJ, Harwell MC, Inglis GJ (2007) Ecology of Seagrass Seeds and Seagrass Dispersal Processes. In: Larkum A, Orth R, Duarte C (eds) Seagrasses: Biology, Ecology, and Conservation. Springer Netherlands, p 111-133

Orth RJ, Luckenbach ML, Marion SR, Moore KA, Wilcox DJ (2006) Seagrass recovery in the Delmarva coastal bays, USA. Aquatic Botany 84:26-36

Pachauri RK, Allen MR, Barros VR, Broome J, Cramer W, Christ R, Church JA, Clarke L, Dahe Q, Dasgupta P, others (2014) Climate Change 2014: Synthesis Report. Contribution of Working Groups I, II and III to the Fifth Assessment Report of the Intergovernmental Panel on Climate Change.

Pandolfi JM (2015) Incorporating Uncertainty in Predicting the Future Response of Coral Reefs to Climate Change. Annual Review of Ecology, Evolution, and Systematics 46:281-303

Pearce AF, Feng M (2013) The rise and fall of the "marine heat wave" off Western Australia during the summer of 2010/2011. Journal of Marine Systems 111:139-156 
Pearce A, Lenanton R, Jackson G, Moore J, Feng M, Gaughan D (2011) The“ marine heat wave" off Western Australia during the summer of 2010/11. Western Australian Fisheries and Marine Research Laboratories

Peterson BJ, Rose CD, Rutten LM, Fourqurean JW (2002) Disturbance and recovery following catastrophic grazing: studies of a successional chronosequence in a seagrass bed. Oikos 97:361-370

Plus M, Deslous-Paoli J-M, Dagault F (2003) Seagrass (Zostera marina L.) bed recolonisation after anoxia-induced full mortality. Aquatic Botany 77:121-134

Pohlert T (2014) The Pairwise Multiple Comparison of Mean Ranks Package (PMCMR).

Preen A (1995) Impacts of dugong foraging on seagrass habitats: observational and experimental evidence for cultivation grazing. Marine Ecology Progress Series $124: 201-213$

Preen AR, Lee Long WJ, Coles RG (1995) Flood and cyclone related loss, and partial recovery, of more than $1000 \mathrm{~km}^{2}$ of seagrass in Hervey Bay, Queensland, Australia. Aquatic Botany 52:3-17

R Core Team (2015) R: A language and environment for statistical computing. R Foundation for Statistical Computing, Vienna, Austria

Robblee MB, Barber TR, Carlson Jr PR, Durako MJ, Fourqurean JW, Muehlstein LK, Porter D, Yarbro LA, Zieman RT, Zieman JC (1991) Mass mortality of the tropical seagrass Thalassia testudinum in Florida Bay(USA). Marine Ecology Progress Series Oldendorf 71:297-299

Short FT, Coles R, Fortes MD, Victor S, Salik M, Isnain I, Andrew J, Seno A (2014) Monitoring in the Western Pacific region shows evidence of seagrass decline in line with global trends. Marine pollution bulletin 83:408-416

Short FT, Wyllie-Echeverria S (1996) Natural and human-induced disturbance of seagrasses. Environmental Conservation 23:17-27

Smale DA, Wernberg T (2013) Extreme climatic event drives range contraction of a habitatforming species. Proceedings of the Royal Society of London B: Biological Sciences 280:20122829

Smit AJ, Brearley A, Hyndes GA, Lavery PS, Walker DI (2005) Carbon and nitrogen stable isotope analysis of an Amphibolis griffithii seagrass bed. Estuarine, Coastal and Shelf Science 65:545-556

Tanner JE (2014) Restoration of the Seagrass Amphibolis antarctica-Temporal Variability and Long-Term Success. Estuaries and Coasts 38:668-678 
Thomson JA, Burkholder DA, Heithaus MR, Fourqurean JW, Fraser MW, Statton J, Kendrick GA (2015) Extreme temperatures, foundation species, and abrupt ecosystem change: an example from an iconic seagrass ecosystem. Global Change Biology 21:1463-1474

Turner T (1983) Facilitation as a successional mechanism in a rocky intertidal community. American Naturalist 121: 729-738.

Tussenbroek BI van, Soissons LM, Bouma TJ, Asmus R, Auby I, Brun FG, Cardoso PG, Desroy N, Fournier J, Ganthy F, Garmendia JM, Godet L, Grilo TF, Kadel P, Ondeviela B, Peralta G, Recio M, Valle M, Heide T van der, Katwijk MM van (In press) Pollen limiation may be a common Allee effect in marine hydrophilous plants: implications for decline and recovery in seagrasses. Oecologia

Unsworth RKF, Collier CJ, Waycott M, McKenzie LJ, Cullen-Unsworth LC (2015) A framework for the resilience of seagrass ecosystems. Marine Pollution Bulletin 100:34-46

Venables W, Ripley B (2002) Modern Applied Statistics with S, 4th edn. Springer New York, New York

Vergés A, Steinberg PD, Hay ME, Poore AG, Campbell AH, Ballesteros E, Heck KL, Booth DJ, Coleman MA, Feary DA, others (2014) The tropicalization of temperate marine ecosystems: climate-mediated changes in herbivory and community phase shifts. In: Proc. R. Soc. B. The Royal Society, p 20140846

Walker DI (1985) Correlations between salinity and growth of the seagrass Amphibolis antarctica (Labill.) Sonder \& Aschers., in Shark Bay, Western Australia, using a new method for measuring production rate. Aquatic Botany 23:13-26

Walker DI, Cambridge ML (1995) An experimental assessment of the temperature responses of two sympatric seagrasses, Amphibolis antarctica and Amphibolis griffithii, in relation to their biogeography. Hydrobiologia 302: 63-70

Walker DI, Kendrick GA, McComb AJ (1988) The distribution of seagrass species in Shark Bay, Western Australia, with notes on their ecology. Aquatic Botany 30:305-317

Walker D, Kendrick G, McComb A (2006) Chapter 23: Decline and Recovery of Seagrass Ecosystems - The Dynamics of Change. In: Larkum A, Orth R, Duarte C (eds) Seagrasses: Biology, Ecology, and Conservation. Springer, Dordrecht, The Netherlands, p 553-565

Walker DI, McComb AJ (1988) Seasonal variation in the production, biomass and nutrient status of Amphibolis antarctica (Labill.) Sonder ex Aschers. and Posidonia australis Hook. f. in Shark Bay, Western Australia. Aquatic Botany 31:259-275 
Walker DI, McComb AJ (1992) Seagrass degradation in Australian coastal waters. Marine Pollution Bulletin 25:191-195

Waycott M, Duarte CM, Carruthers TJ, Orth RJ, Dennison WC, Olyarnik S, Calladine A, Fourqurean JW, Heck KL, Hughes AR, others (2009) Accelerating loss of seagrasses across the globe threatens coastal ecosystems. Proceedings of the National Academy of Sciences 106:12377-12381

Wernberg T, Smale DA, Tuya F, Thomsen MS, Langlois TJ, De Bettignies T, Bennett S, Rousseaux CS (2013) An extreme climatic event alters marine ecosystem structure in a global biodiversity hotspot. Nature Climate Change 3:78-82

Wu L, Cai W, Zhang L, Nakamura H, Timmermann A, Joyce T, McPhaden MJ, Alexander M, Qiu B, Visbeck M, others (2012) Enhanced warming over the global subtropical western boundary currents. Nature Climate Change 2:161-166 


\section{CHAPTER IV}

EFFECTS OF MASSIVE SEAGRASS LOSS ON ABUNDANCE AND HABITAT USE PATTERNS OF AN INTACT MEGAFAUNA COMMUNITY 


\section{Abstract}

There is growing recognition that the effects of climate change disturbances on ecosystems will be mediated, in part, by biotic interactions in those ecosystems rather than the sum of individual species responses to changes in abiotic conditions. Apex predators are likely candidates to be "biotic multipliers of climate change" in part because of their ability to widely generate top down control through both consumptive and non-consumptive pathways. This, along with global rates of predator loss, has led to an increasing effort to understand what structures top-down control in ecosystems. While the effects of predator losses on top-down control receive much attention, other factors also mediate the strength of predator consumptive and non-consumptive effects, such as prey body condition. As a result, abiotic stressors that reduce prey body condition directly or indirectly may play a critical role in mediating top-down control in ecosystems by increasing risk-taking of energetically-stressed individuals. Here, I use a climactic extreme event (marine heat wave) and associated catastrophic seagrass loss as a natural experiment to investigate the impact of widespread resource loss on the apex predator (tiger shark, Galeocerdo cuvier) and mesoconsumer communities of Shark Bay, Western Australia. I compare data from after the event to a nearly 13 year pre-disturbance dataset. Tiger shark catch rates were not significantly different after the seagrass die-off, suggesting that predation risk remains similar after the disturbance. In contrast, most mesoconsumer populations declined significantly as food and refuge resources were reduced. Furthermore, two species of mesoconusmers (dolphins, cormorants) significantly increased use of dangerous but profitable shallow seagrass beds following the die-off. Because the relative spatial distribution of their food resources was similar 
pre- and post-seagrass die-off, this pattern is consistent with increased risk-taking. These findings suggest that resource reductions can alter anti-predator behavior and reduce the strength of risk effects at population and ecosystem scales even when apex predator communities remain stable. Reduced responsiveness of prey to the landscape of fear may result in predator effects manifesting more strongly through direct predation and less through predation risk as resource species continue to be disturbed by climactic extremes globally.

\section{Introduction}

Most studies of the ecological effects of climate change have focused on how organisms and ecosystems will respond to changes in average environmental conditions. However, extreme climatic events - such as heat waves and droughts - can rapidly alter ecosystems and may be a more immediate threat to long-term ecosystem integrity.

Climate change is predicted to alter extreme events including the frequency and duration of heat waves, heavy precipitation events and droughts, strength of tropical ocean currents, and even the frequency of extremes in the ENSO cycle (IPCC 2014, Wu et al. 2012, Cai et al. 2014, 2015). While climactic extremes can change species abundance directly by causing mortality through direct forcing of the physical environment (e.g., Matich et al. 2012, Fraser et al. 2014, Thomson et al. 2014), they can also alter species interactions, which are likely to influence how ecosystems respond to climate change (Zarnetske et al. 2012, Taylor et al. 2015). Not all species interactions are equally powerful, however. Apex predators may be particularly powerful biotic multipliers of climate change (sensu Zarnetske et al. 2012) in part because of their large number of species interactions and ability to generate widespread non-consumptive (i.e., "risk") 
effects (Jeffries and Lawton 1984, Heithaus et al. 2008). Investigations solely into numerical effects of climactic extremes on species (i.e., changes in abundance or density) without accounting for changes to species interactions, particularly when strong interactions are known to exist, may fail to predict the overall effects of climate extremes in ecosystems.

Predators can exert top-down control on prey through direct predation, risk effects, and the interaction of the two (e.g., Schmitz et al. 1997, Lima 1998, Dill et al. 2003, Werner and Peacor 2003). Predation risk can greatly alter prey behavior and forager impacts by inducing changes in absolute foraging intensity, spatial and temporal patterns of foraging, and foraging tactics of prey (e.g., Lima and Dill 1990, Creel et al. 2005, Heithaus et al. 2012 ). Under some circumstances, risk effects can even be more powerful than consumptive effects (e.g., Werner and Peacor 2003, Creel and Christianson 2008). This is because consumptive effects can be limited by predator properties (such as population size or handling time) or result in compensatory growth of remaining prey, while risk effects can affect entire populations simultaneously and quickly and result in lowered foraging, condition, and fitness (Sinclair and Pech 1996; Creel et al. 2008, Creel 2011, Heithaus et al. 2012). Predation risk, and resulting anti-predator behavior, can thus generate behaviorally mediated indirect interactions (BMIIs, also known as behaviorally mediated trophic cascades, or BMTCs) (Dill et al. 2003) with potentially strong effects on lower trophic levels (e.g., Schmitz et al. 1997, Ripple and Beschta 2004, Burkholder et al. 2013b). Understanding the drivers of this anti-predator behavior can therefore lead to better predictions of how top-down control may change as ecosystems are altered. 
Generally, animals can be expected to optimize their behavior to balance fitnessenhancing behaviors- such as foraging and reproduction- with the risk of death from predators (i.e., anti-predator behavior, Lima and Dill 1990). The tactics employed in anti-predator behavior can be diverse and are affected by factors such as prey body condition and life history (the "asset protection principle", Clark 1994), predator encounter probability and subsequent escape probability (Lima and Dill 1990), landscape features (Heithaus et al. 2009), prey escape mode (Heithaus et al. 2009, Wirsing et al. 2010), and predator hunting mode (e.g., Pressier et al. 2007). All of these factors can also alter the effectiveness of anti-predator behavior, which can in turn alter the level of investment of anti-predator behavior and the strength of BMTCs.

Ecological theory suggests that species that are relatively long lived, highly iteroparous, or in good body condition should invest more heavily in anti-predator behavior because their chance for future reproductive success is high; individuals that are semelparous or energetically stressed, however, are likely to reduce anti-predator behavior and accept increased predation risk in order to fulfill immediate energy or reproductive demands (e.g., McNamara and Houston 1990, Clark 1994, Warner 1998, Frid et al. 2012). This results in a dynamic investment in anti-predator behavior dependent on both properties of predation risk and prey (i.e., the "risk allocation hypothesis", Lima and Bednekoff 1999). The myriad factors which can alter the intensity of anti-predator behavior results in context dependence of the nature and strength of risk effects and BMTCs (e.g., Heithaus et al. 2009). 
Because prey adopt anti-predator behavior in a state-dependent manner, prey in poor condition are more likely to succumb to actual predation events, while their acceptance of higher predation risk weakens the influence of risk effects (Anholt and Werner 1995, Sinclair and Arcese 1995, Heithaus et al. 2007b, Heithaus et al. 2008). Therefore, resource loss may mediate the absolute and relative strengths of consumptive and non-consumptive predator effects (Heithaus et al. 2008), even if predator abundance and behavior remains stable. However, most investigations into human-induced shifts in consumptive and non-consumptive predator effects have focused on the role of predator loss, not of ecosystem disturbance and resource loss. Furthermore, the role that climactic extremes may play in influencing the importance of non-consumptive predator effects has received little attention. Given increased rates of anthropogenic disturbance and top predator loss, it is thus critical to understand in what ways climate-related disturbances may influence top down control in ecosystems.

Seagrass ecosystems support diverse consumer communities and provide myriad ecosystem functions including primary production, habitat creation, sediment stabilization, and carbon sequestration and storage (e.g., Costanza et al. 1997, Heck et al. 2003, Orth et al. 2006, Fourqurean et al. 2012). Despite their importance as foundations of coastal ecosystems, seagrass habitats are declining at alarming rates both through local stressors such as sedimentation and eutrophication (e.g., Short and Wyllie-Echeverria 1996, Waycott et al. 2009) and climactic extremes including marine heat waves and hurricanes (e.g., Fraser et al. 2014, Thomson et al. 2014). Seagrass habitats subjected to intense stressors therefore represent a valuable opportunity to test a priori predictions (e.g., Heithaus et al. 2008) about how resource loss affects abundance and anti-predator 
behavior of seagrass-associated fauna. Such tests provide critical insights into our ability to predict how top down control will change in response to disturbance and climate change.

The objective of this study was to determine the impacts of widespread seagrass loss on abundance and habitat use patterns of large-bodied consumers following a widespread seagrass decline in Shark Bay, Western Australia. Specifically, I used long term standardized survey data (shark fishing, visual surface transect surveys) before (1997-2010) and after (2012-2014) a heat-wave induced seagrass die-off to test whether 1) reduction of the resource base resulted in reduced abundance of air-breathing megafauna and large sharks, and 2) whether resource loss and a concentration of remaining resources to dangerous shallow seagrass bank altered risk-sensitive habitat use patterns of tiger shark prey.

\section{Methods}

Shark Bay $\left(25^{\circ} 45^{\prime} \mathrm{S}, 113^{\circ} 44^{\prime} \mathrm{E}\right)$, Western Australia is a shallow $(<15 \mathrm{~m}), 13,000$ $\mathrm{km}^{2}$ semi-enclosed subtropical embayment situated approximately $800 \mathrm{~km}$ north of Perth. The bay historically contained over $4000 \mathrm{~km}^{2}$ of seagrass (Walker et al. 1988)- among the largest seagrass ecosystems on earth. Shark Bay's seagrass assemblage has been historically dominated by the temperate seagrass Amphibolis antarctica, which accounted for approximately $85 \%$ of seagrass cover and often formed dense, monospecific stands of 90-100\% cover where it occurred (Walker et al. 1988, Burkholder et al. 2013a). Because of the height, density, and productivity of A. antarctica beds, this seagrass is a structurally complex ecosystem engineer (sensu Jones et al. 1994) that creates extensive 
benthic habitat, stabilizes sediment, and contributes significant primary and secondary production in this ecosystem (Walker 1985, Walker and McComb 1988). Indeed, these expansive seagrass beds directly or indirectly support a wide variety of megafauna (see below). Despite its large size, Shark Bay is largely undeveloped with a small human population and relatively few local and regional anthropogenic stressors (Department of Environment and Conservation 2008).

The study area, immediately north of Monkey Mia, consists of a series of nearshore shallow $(<4 \mathrm{~m})$ seagrass banks separated by deep $(6-12 \mathrm{~m})$, seagrass-depauperate channels (Heithaus 2001, Fig. 1). Since 1997 this study area has been used as a model system to understand the importance of risk effects of tiger sharks (Galeocerdo cuvier) on associated prey species and ecosystem structure (Heithaus et al. 2012, Burkholder et al. 2013, Bessey et al. 2016). Tiger sharks' potential air-breathing prey in this system include megaherbivores [dugongs (Dugong dugon) and green sea turtles (Chelonia mydas)], piscivourous mesopredators [Indo-Pacific bottlenose dolphins (Tursiops aduncus), Piedcormorants (Phalacrocorax spp), sea snakes (subfamily Hydrophiinae)], and benthic invertivores [loggerhead sea turtles (Caretta caretta), Heithaus et al. 2012 and references therein]. Before the seagrass die-off, shark abundance varied temporally with consistently high shark abundances during warm months (September-May), and very low abundances during most - but, importantly, not all - winters (June-August, Heithaus 2001, Wirsing et al. 2006) and with higher use of shallow habitats than deep ones (Heithaus et al. 2002, 2006). These shallow seagrass habitats were characterized by relatively higher density and quality of food resources for herbivores (dugongs, green turtles) and mesopredators (sea snakes, cormorants, dolphins), but also carry an increased 
risk of predation by tiger sharks (see Heithaus et al. 2012 and references therein). In response to these spatiotemporal patterns of risk and food availability, before the seagrass die-off multiple consumer species were distributed in rough proportion to their food supply (i.e., an ideal free distribution, Fretwell and Lucas 1970) when predation risk was low, but overused resource-poor but safer deeper habitats during dangerous periods (see Heithaus et al. 2012 for a review). These shifts in habitat use resulted in a behaviorallymediated trophic cascade that structured the seagrass community in this system with intense herbivory from megaherbivores concentrated in safer areas (Burkholder et al. 2013b).

A subtropical seagrass ecosystem, Shark Bay marks the northern boundary for the temperate seagrass A. antarctica (Walker et al. 1988). In the Austral summer of 2011 ocean temperatures rose $2-4^{\circ} \mathrm{C}$ above average for a two-month period (Wernberg et al. 2013) driven by strong La Niña conditions that increased the poleward flow of tropical water via the Leeuwin current along the Western Australia coast (Pearce and Feng 2013). In Shark Bay, daytime water temperatures for the month of February were $29.8^{\circ} \mathrm{C}\left(3.5^{\circ} \mathrm{C}\right.$ above average), and average monthly temperatures for January, February, and March 2011 exceeded average temperatures for February, the hottest month in most years (Chapter III). Following this extreme event, A. antarctica experienced widespread declines in cover that exceeded $90 \%$ in many areas of Shark Bay (Thomson et al. 2014, Fraser et al. 2014), with the magnitude of seagrass die-off positively correlated with depth (Thomson et al. 2014). Seagrass loss of this magnitude has not been previously reported in Shark Bay. The seagrass loss was also accompanied by a $\sim 40 \%$ decline in 
benthic fish biomass in shallow habitats and a $27 \%$ decline in fish biomass in deep habitats (Nowicki et al. in preparation).

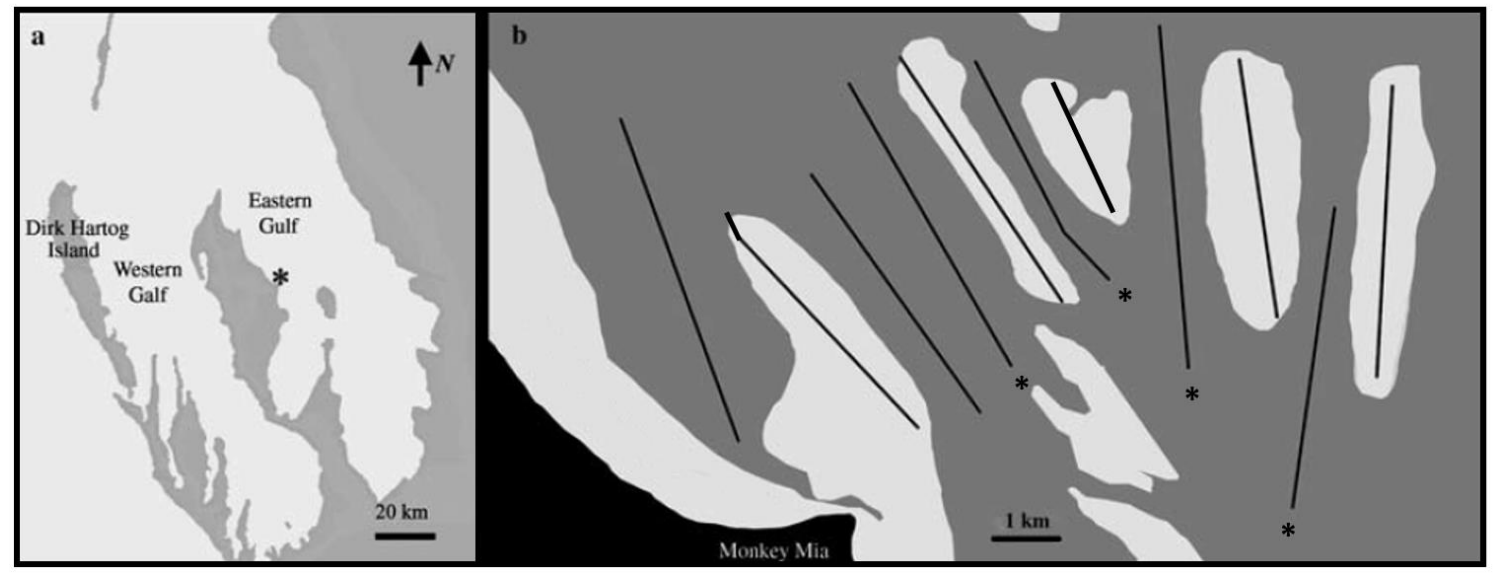

Figure 1. Shark Bay, Western Australia. The study area is located immediately north of Monkey Mia (asterisk, a) in the Eastern Gulf. The study area is typified by a series of shallow $(<4.0 \mathrm{~m})$ seagrass banks (light grey) separated by deep $(6-12 \mathrm{~m})$ sandy channels habitats (dark grey). Locations of transect surveys are indicated by black lines. Shark fishing occurred on the three transects marked with asterisks. Modified from Heithaus (2005).

\section{Field methods}

While fishing and transects occurred in all months, field effort was largely concentrated between February and October in most years to ensure capture of seasonal transitions. Shark abundance was estimated using a standardized top-set drumline method established in 1997 (Heithaus 2001). From 1997-2015, tiger sharks were sampled via single hook top set drumlines set in three deep channels in the study system (Fig. 1). On each fishing day (approximately 4 days per field month, mean=3.86, $s=2.07$ ), up to 10 baited drumlines were set at dawn. Drumlines were secured to the bottom with a danforth anchor attached to $20 \mathrm{~m}$ of line; a 25L floating drum suspended a single baited 13-0 Mustad Shark Hook 1-2 m below the surface (Heithaus 2001, Wirsing 
et al. 2006). Some sets were baited with $12-0$ or $14-0$ sized hooks, but since hook size can impact tiger shark catch rates in this system (Heithaus 2001), these sets are excluded and are not mentioned further. Drumlines were usually separated by $300 \mathrm{~m}$; occasionally, drumlines were set concurrently in two channels with drums 700m apart. Previous work has shown these differences in deployment to not influence catch rates (Wirsing et al. 2006) so results from both deployment types were pooled.

Drumlines were baited with $\sim 1.5 \mathrm{~kg}$ of fish; bait species varied, but was dominated by Australian Salmon (Arripis trutta, 37.0\% of soak time), Pink Snapper (Pagrus auratus $15.7 \%$ ), Emperor (Lethrinis spp., 14.4\%), Tailor (Pomatomus saltatrix, 13.7\%), and Sea mullet (Mugil cephalus, $8.8 \%$ ), which made up c.a. $90 \%$ of soak time. Because catch data were expressed per-day for analysis, and previous analysis of sharks caught using these bait species (excluding emperor) indicate bait identity does not significantly influence catch rates, a bait correction factor was not applied. Lines were checked every 2-4 hours for bait loss and shark presence. Soak time was calculated as time between bait entry and bait removal; for hooks at which bait was missing or a shark was captured, bait removal was assumed to occur halfway between checks. Catch data from all sets in a day were pooled to obtain daily averages and reduce zero-inflation.

Shark handling procedures are described in detail elsewhere (Heithaus 2001). Briefly, hooked sharks were brought along the $4.5-5.5 \mathrm{~m}$ research vessel and were allowed to swim freely to minimize stress while the vessel idled forward. Shark total length (TL), fork length (FL), and pre-caudal length (PCL) was measured to the nearest $\mathrm{cm}$ and a unique numbered rototag was placed in the dorsal fin. 


\section{Transect surveys}

Densities of air breathing megafauna (e.g., dolphins, dugongs, green and loggerhead sea turtles, cormorants, and sea snakes) were assessed via visual belt transects. Eleven transects, ranging in length from 2.9-4.5 km, were established in the study area in 1997; five over shallow (<3m depth) seagrass banks, and six over deeper ( 6-12m depth) channel and sandflat habitats (Heithaus 2001, Fig 1). Each transect was run between sunrise and sunset c.a. 4 times a month at $6-9 \mathrm{~km} / \mathrm{hr}$ using a $4.5-5.5 \mathrm{~m}$ vessel with an outboard motor and usually 3 observers (mean=3.24, $s=1.05$ ) from 1998-2014 (excluding 2001 and 2005). Because of interspecific differences in size and surface behavior, transect widths varied among species (Table 1). Only individuals at the surface that had not passed the boat were counted. At each sighting, depth, bottom cover under the boat, heading and distance to the animal were also recorded.

Slow vessel speeds, relatively short dive times (except for sea turtles, see below) and direct comparisons of relative change in animal density within habitat types and seasons minimize the need for correction factors (Heithaus et al. 2012, Wirsing et al. 2007a). To minimize recounting individuals, transects were not run more than once per day, and transects were run in haphazard order and direction. Cormorants that fled from the boat upon approach were watched until they landed or left the area to minimize recounting. Transects were only run in Beaufort sea state conditions of 3 or lower to minimize sampling bias (ca. $87 \%$ were $\leq 2$ ). To minimize the influence of large groups which were very rarely encountered $(<0.1 \%$ of sighting events), I excluded encounters in which group size exceeded 30 individuals from analysis $(n=12$ occurrences for 
cormorants, $\mathrm{n}=1$ occurrence for dolphins). All transects from 2011 were excluded from analysis to allow for a clear separation between periods before and after the heat wave.

Sea turtles are capable of lengthy dives and spend a relatively small proportion of their time at the surface; as such, reliable identification of turtles to species was not always possible. To derive estimates of the proportions of green and loggerhead turtles of unknown sightings, I extracted and pooled species proportion data from years in which turtle identification rates were high $(>75 \%, n=9$ years) and applied the resulting estimate to years in which identification rates were low $(<75 \%, \mathrm{n}=5$ years $)$. Because only two post-die-off years had high identification success, formal statistical comparison between time periods was not possible. However, species proportions were similar in both time periods, so post-decline years (2012-2014) and pre-decline years (1998-2010) were pooled.

Turtle dive behavior results in significant availability bias for these species (Thomson et al. 2012) which can greatly impact density estimates when using surface surveys (Thomson et al. 2013). Since turtle dive profiles and proportional surface use are temperature and depth dependent (derived within the study site, Thomson et al. 2012), I applied a correction factor that took into account water temperature (monthly average, see Chapter III), depth (averaged across each transect), and turtle species. All reported values have been corrected for availability bias.

\section{Data analysis}

All data were analyzed in R. studio version 0.99.892 (RStudio Team 2015). Shark catch rates were expressed as sharks per hour of fishing effort, hereafter referred to 
as sharks per hook hour. All hooks set in a day were pooled. Catch rates appear to be a reliable measure of tiger shark abundance since sighting frequency of free swimming sharks is directly related to catch rates and sharks tagged with passive acoustic tags $(n=8)$ have only been detected during periods of high catch rates (e.g., Heithaus 2001).

Furthermore, tiger sharks have been caught even at low winter temperatures, suggesting that changes in catch rates are not because of temperature-induced suspension of feeding (Wirsing et al. 2006, this study).

Table 1. Belt transect widths and sighting distances for each species.

\begin{tabular}{llc}
\hline \multicolumn{1}{c}{ Common name } & Scientific name & $\begin{array}{c}\text { sighting distance/ } \\
\text { transect width (m) }\end{array}$ \\
\hline Indo-Pacific bottlenose dolphin & Tursiops cf. aduncus & $200 / 400$ \\
Dugong & Dugong dugon & $100 / 200$ \\
Green turtle & Chelonia mydas & $30 / 60$ \\
Piedcormorant & Phalacrocorax varius & $30 / 60$ \\
Loggerhead turtle & Caretta caretta & $30 / 60$ \\
Bar-bellied sea snake & Hydrophis elegans & $5 / 10$ \\
Olive-headed sea snake & Disteria major & $5 / 10$ \\
Shark Bay sea snake & Aipysurus pooleorum & $5 / 10$ \\
\hline
\end{tabular}

Shark catch data were analyzed via generalized additive mixed modelling and model selection using the "gamm" function in the mgcv package (Wood 2011). To minimize impact of zero inflation and skew, the following transformation was applied to catch data:

$$
\sqrt{(\text { Sharks per hook hour } * 100)+1}
$$

Day of year (DOY) was included as a smoothing function with cubic regression splines; time period (pre/post decline), season (warm, cool) and their interaction were 
included as fixed effects in the full model. Because year is nested within time period, it could not be included as a fixed effect and was instead included as a random effect. Transect identity was also included as a random effect in the full model to account for repeated visits. A monthly variance structure (i.e., "VarIdent" function in the nlme package, Pinheiro et al. 2016) was applied to address model heterogeneity. DOY was treated as a continuous variable, while season and pre/post die-off were treated as discrete factors. Because shark catch rates are already a property of soak time, an offset for fishing effort was not applied. I used an information theoretic model selection approach to choose the optimal model (Anderson 2004). Briefly, the Akaike Information Criteron (AIC) was used to determine the optimal random and fixed effects structures; differences in AIC >2 were interpreted to indicate significant model improvement (Zuur et al. 2009, Anderon 2004). In the event of $\triangle \mathrm{AIC}<2$, the more parsimonious model was retained.

Sightings of air-breathing fauna on transect surveys were converted to densities based on sighting band width and transect lengths (and for turtles, availability bias). To assess general impacts of seagrass decline on fauna densities at a system wide scale, a general linear mixed-effects model was applied to density data using the "glmer" function in the lme4 package in $\mathrm{R}$ (Bates et al. 2015). In each model, time period was the only fixed factor; season, habitat, and transect identification were included as separate random intercepts (Zuur et al. 2009). The data were positive and included a large proportion of zeroes; however, because the density data were also continuous, a negative-binomial distribution was not appropriate to model the data without use of an offset (Zuur et al. 2009). Therefore, a tweedie distribution was applied with a power variance structure 
which differed by species and model (packages statmod and tweedie, Giner and Smyth 2016, Table 6).

To assess changes in faunal habitat use patterns in relation to the die-off, the significance of a three-way interaction between season (cool, warm), habitat (deep, shallow), and time period (pre-die-off, post-die-off) on density of each species were assessed with generalized linear mixed effects modeling, again using "glmer". Since shark abundance correlates strongly with season in most years (see results), season was used as a proxy for predation risk. Transect identity was a random effect to account for repeated transect visits. Results were again modeled using a tweedie distribution (link power=0, var power=2, packages "tweedie" and "statmod", Dunn 2014, Giner and Smyth 2016). For each model, a "bobyqa" control optimizer was applied with 5 integration points. I interpreted a significant three way interaction between habitat, season, and time period to indicate that seasonal habitat use patterns had changed in response to the seagrass die-off.

\section{Results}

There were 421 shark fishing days between 1998-2015 (1997 was excluded because of methodological differences with later years). Days in which hook hours were low ( $<10$ hook hours, $n=6$ days $)$ were excluded, as were fishing days from 2011 when the heat wave occurred ( $\mathrm{n}=23$ days), leaving 26,218 hook hours over 392 fishing days (298 days pre-die-off, 94 days post-die-off). Daily shark fishing effort before the die-off (64.96 \pm 23.74 hook hours per day) was lower than after the die-off $(72.97 \pm 22.56$ hook hours per day, One-way ANOVA, $\mathrm{F}_{1,390}=9.10$, p=0.003), a pattern driven by increased 
soak time in post-die-off cold seasons (Two-way ANOVA on interaction term,

$\mathrm{F}_{1,388}=4.59, \mathrm{p}=0.03$, Fig $\left.2 \mathrm{a}\right)$. Longer soak times tended to yield lower sharks per hook our both for large sharks ( $>3 \mathrm{~m}$ ) (one-way ANOVA, $\mathrm{F}_{1,390}=84.7, \mathrm{p}<0.0001, \mathrm{R}^{2}=0.178$ ) and for sharks as a whole ( one-way ANOVA, $\mathrm{F}_{1,390}=86.1$, $\mathrm{p}<0.0001, \mathrm{R}^{2}=0.181$ ), making my findings of no significant decline in seasonal shark abundances conservative (Fig. 2 b,c).

Within fishing days that were retained for analysis, 828 sharks from 15 species were captured (553 individuals from 9 species pre-die-off, 275 individuals from 12 species post-die-off). The large shark community was dominated overwhelmingly by tiger sharks, Galeocerdo cuvier, which made up $89.6 \%$ of the overall catch (742 of 828 captures). Tiger sharks dominated the catch in both time periods $(91.5 \%$ and $85.5 \%$ of catch, respectively); this pattern was even more pronounced among large sharks $(\geq 3.0 \mathrm{~m}$ TL), with G. cuvier making up $99.5 \%$ and $97.1 \%$ of large shark catch before and after the die-off, respectively. The next most common species was the sandbar shark (Carcharhinus plumbeus), which made up 5.6\% and $5.1 \%$ of the catch before and after the die-off, respectively; all other shark species were rarely encountered.

Under both model selection procedures, models performed similarly, with the optimal model containing the DOY smoother only for both the large shark model and the all shark model; this suggests that tiger shark catch rates were similar in both time periods (Tables 2,3, Fig 3). Seasonality in catch rates, which is characteristic of this system in most (but not all) years, did not change in response to seagrass die-off (Fig. 3).

\section{Changes in air-breathing megafauna populations}


In total, 3329 transects were run (2617 pre-die-off, 712 post-die-off), resulting in 12,310 linear kilometers surveyed; in total, 22,007 animals were sighted (Table 4). In years where turtle species identification success was high, green turtles made up a smaller proportion of sightings $(\mu=0.42, s=0.09)$ than loggerhead turtles $(\mu=0.58, s=0.09)$. Impacts of the seagrass die-off on abundance varied by species. Dolphin and loggerhead turtle relative densities were not significantly different between time periods $\left(t_{1}\right.$, $3314=1.284, \mathrm{p}=0.199$ and $\mathrm{t}_{1,3314}=1.502, \mathrm{p}=0.133$, respectively; Tables 4 and 5, Fig $\left.4 \mathrm{~A}, \mathrm{P}\right)$. Relative densities of all other species dropped significantly in response to the seagrass die-off. Dugong densities dropped by $54.4 \%\left(\mathrm{t}_{1,3314}=2.455, \mathrm{p}=0.014\right)$, while cormorant and green turtle densities declined by $35.4 \%\left(\mathrm{t}_{1}, 3314=7.459, \mathrm{p}<0.0001\right)$ and $24.4 \%\left(\mathrm{t}_{1}\right.$, 3314=2.338, p <0.0194), respectively (Tables 4 and 5, Fig 4 D, G). Sea snakes suffered the largest losses, declining in density by $76.9 \%\left(\mathrm{t}_{1,3314}=5.433\right.$, $\mathrm{p}<0.0001$, Tables 4 and 5 , Fig $4 \mathrm{~J})$.

Mixed effect modelling indicated that seasonal habitat use patterns shifted after the resource decline for three of the six species surveyed (Table 5). Neither dolphins nor cormorants changed habitat use patterns in cold months, but both increased their relative use of dangerous but profitable seagrass banks over safer but less profitable deep habitats during warm months when predation risk is highest (Fig. 4B-C, H-I). The sea snake model also indicated shifts in seasonal habitat use patterns, though these results are more difficult to interpret (Fig. 4 K, L). Dugongs, green turtles, and loggerhead turtles did not change seasonal habitat use patterns (Table 5, Fig 4). Instead, dugongs and green turtles became less common in the warm season in both habitats, while loggerhead turtles 
became more common in shallow habitats in both seasons (Fig. 4 E-F, N-O, and Q-R, respectively).
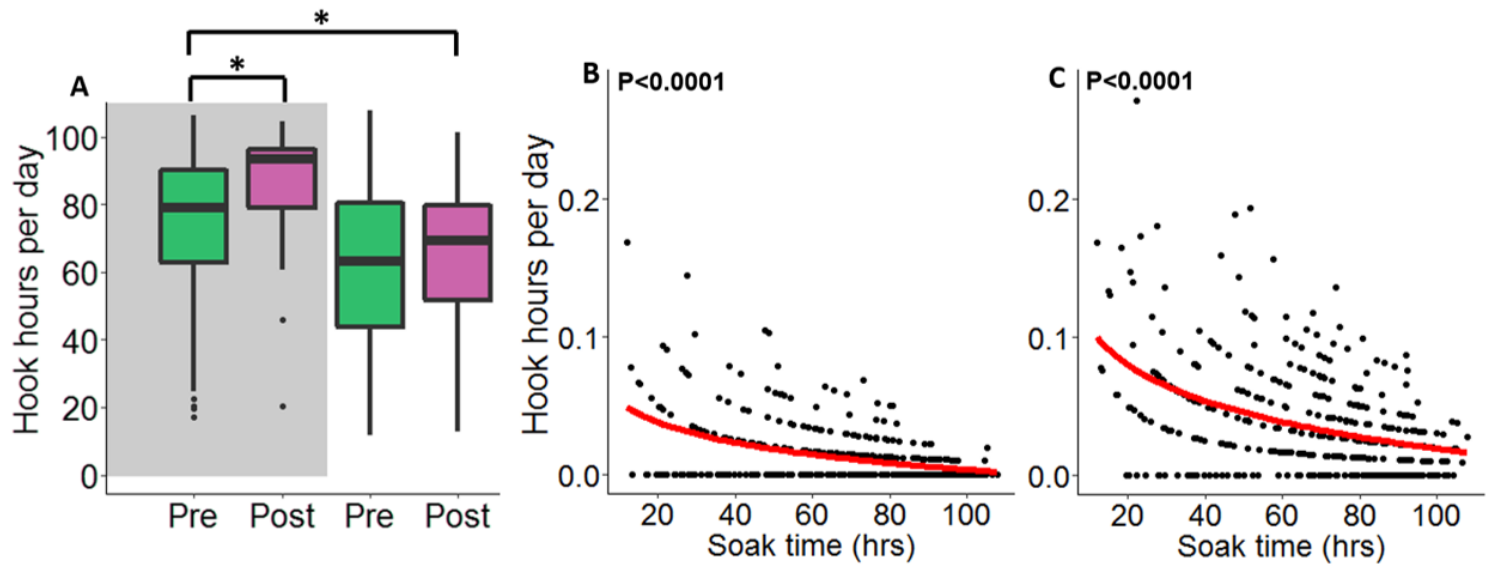

Figure 2. Shark fishing effort during pre-die-off (1998-2010) and post-die-off (20122015) periods broken up by season and time period (A). Pre-die-off effort is displayed in blue; post-die-off effort is displayed in orange. Shaded and unshaded areas refer to cold and warm seasons, respectively. Relationships between fishing effort and sharks per hook hour (in all seasons combined) for large ( $>3 \mathrm{~m}$ ) sharks (B) and all sharks (C). 


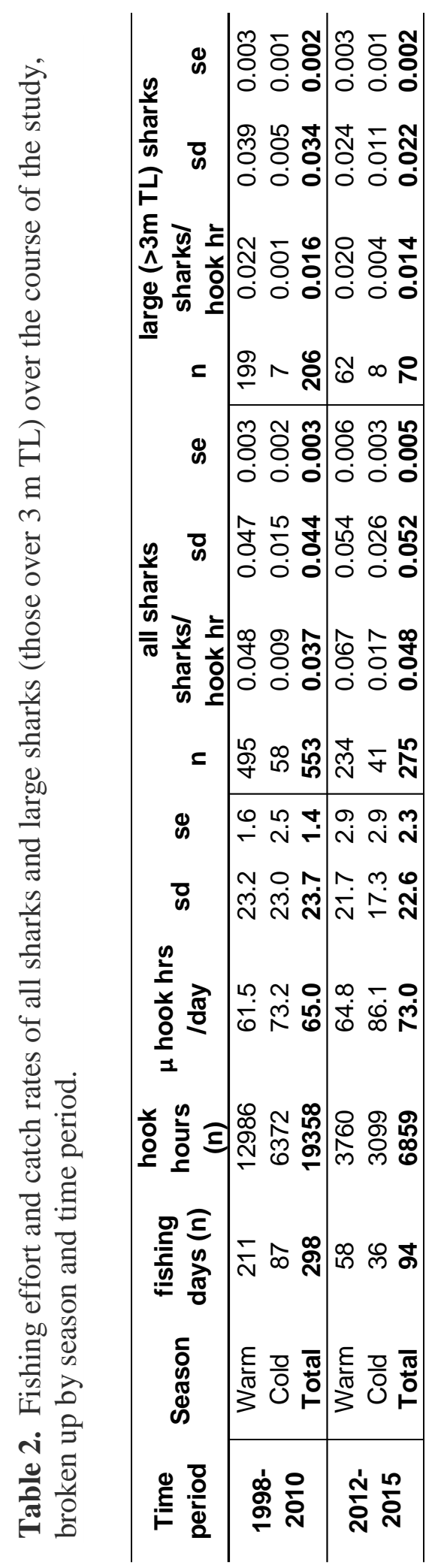


Table 3. General additive mixed models (GAMMs) used in model selection for shark catch rates. Day of year (DOY) was included as a smoother function in all models, with season (cold, warm), time period (pre-die-off, post-die-off), and their interaction included as potential fixed effects. Transect identity (ID) and year (Yr) were random effects. AIC=Akaike's Information Criterion. The optimal model is highlighted in bold.

\begin{tabular}{|c|c|c|c|c|c|}
\hline Fixed effects & $\begin{array}{c}\text { Random } \\
\text { effects }\end{array}$ & $\begin{array}{l}\text { AlC (all } \\
\text { sharks) }\end{array}$ & $\Delta \mathrm{AIC}$ & $\begin{array}{c}\text { AIC } \\
\text { (large } \\
\text { sharks) }\end{array}$ & $\triangle \mathrm{AIC}$ \\
\hline s(DOY)+Prepost*Season & $\mathrm{Yr}, \mathrm{FZ}$ & 805.14 & 3.51 & 630.1 & 2.14 \\
\hline s(DOY) +Prepost+Season & Yr, FZ & 804.28 & 2.65 & 629.16 & 1.20 \\
\hline $\mathrm{s}(\mathrm{DOY})+$ Prepost & Yr, FZ & 803.54 & 1.91 & 627.17 & -0.79 \\
\hline s(DOY) +Season & Yr, FZ & 802.42 & 0.79 & 629.96 & 2.00 \\
\hline s(DOY) & Yr, FZ & 801.63 & 0 & 627.96 & 0 \\
\hline
\end{tabular}



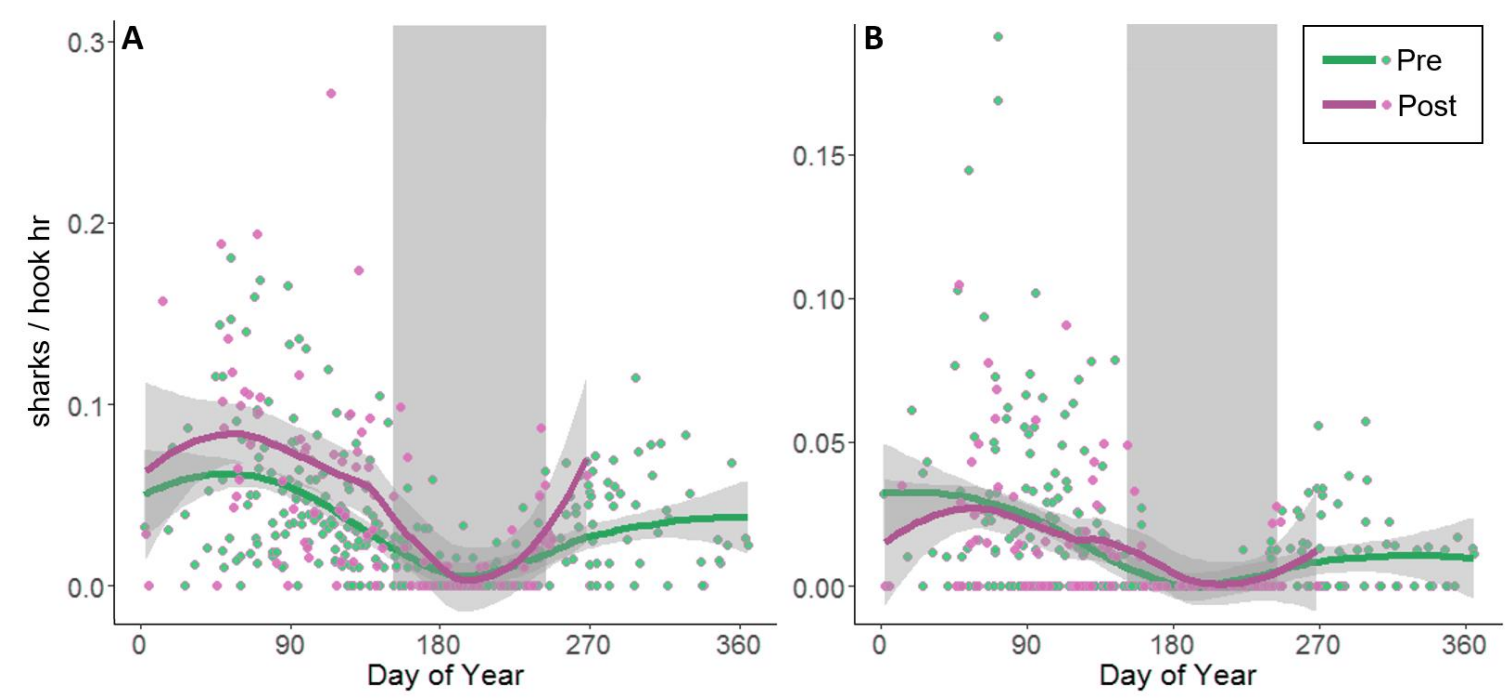

Figure 3. Catch rates of all sharks (A) and sharks $\geq 3 \mathrm{~m}$ TL (B) by day of year and time period. LOESS smoothers ( $\operatorname{span}=0.75$ ) with $95 \%$ confidence intervals (shaded buffers) have been applied to better visualize temporal patterns. The cold season is represented by the shaded vertical bar.

Table 4. Densities for potential tiger shark prey. Turtle sightings include individuals for which species could not be determined, distributed to species based on species ratio estimates (see methods).

\begin{tabular}{|c|c|c|c|c|c|c|c|c|}
\hline \multirow[b]{2}{*}{ species } & \multicolumn{4}{|c|}{$1997-2010$} & \multicolumn{4}{|c|}{ 2012-2015 } \\
\hline & $\begin{array}{c}\text { transects } \\
\text { run }\end{array}$ & $\begin{array}{c}\text { animals } \\
\text { sighted (n) }\end{array}$ & $\begin{array}{c}\text { density } \\
\text { (km2) }\end{array}$ & se & $\begin{array}{c}\text { transects } \\
\text { run }\end{array}$ & $\begin{array}{c}\text { animals } \\
\text { sighted }(n)\end{array}$ & $\begin{array}{c}\text { density } \\
\text { (km2) }\end{array}$ & se \\
\hline dolphins & \multirow{6}{*}{2617} & 5150 & 1.268 & 0.053 & \multirow{6}{*}{712} & 1605 & 1.479 & 0.111 \\
\hline dugongs & & 645 & 0.349 & 0.04 & & 77 & 0.159 & 0.025 \\
\hline sea snakes & & 417 & 4.728 & 0.316 & & 28 & 1.093 & 0.248 \\
\hline cormorants & & 10765 & 20.609 & 0.742 & & 1885 & 13.305 & 0.756 \\
\hline loggerhead turtles & & 624 & 1.856 & 0.095 & & 139 & 1.539 & 0.177 \\
\hline green turtles & & 589 & 8.022 & 0.406 & & 118 & 6.06 & 0.693 \\
\hline
\end{tabular}


Table 5. GLMM results from density and habitat use models of air-breathing mesoconusmers. Details of model construction can be found in the methods.

\begin{tabular}{|c|c|c|c|c|c|c|c|c|}
\hline \multirow[b]{2}{*}{ species } & \multicolumn{4}{|c|}{ Density model } & \multicolumn{3}{|c|}{ Habitat use model } & \multirow{2}{*}{$\begin{array}{c}\text { variance } \\
\text { power }\end{array}$} \\
\hline & df & $t$ value & $\operatorname{Pr}(>|z|)$ & $\begin{array}{c}\text { variance } \\
\text { power }\end{array}$ & df & $t$ value & $\operatorname{Pr}(>|z|)$ & \\
\hline dolphins & 1,3313 & 1.284 & 0.199 & 0.5 & 1,3317 & 5.682 & $<0.0001$ & 2 \\
\hline dugongs & 1,3313 & 2.455 & 0.014 & 1.2 & 1,3317 & 0.355 & 0.722 & 1.2 \\
\hline sea snakes & 1,3313 & 5.433 & $<0.0001$ & 1 & 1,3317 & 5.865 & $<0.0001$ & 0.5 \\
\hline cormorants & 1,3313 & 7.459 & $<0.0001$ & 2 & 1,3317 & 8.156 & 0.002 & 1 \\
\hline loggerhead turtles & 1,3313 & 1.502 & 0.133 & 1.5 & 1,3317 & 1.165 & 0.244 & 1.5 \\
\hline green turtles & 1,3313 & 2.338 & 0.0194 & 1 & 1,3317 & 0.084 & 0.933 & 2 \\
\hline
\end{tabular}

\section{Discussion}

My results suggest that widespread resource loss can result in large declines in densities of consumers across multiple trophic levels as well as alter habitat use of mesoconsumers, even when apex predator populations are stable. Specifically, reductions in seagrass and teleost biomass (Thomson et al. 2014, Chapter III) resulted in shifts in habitat use patterns of several species of large-bodied piscivores that are consistent with increased risk-taking. These results suggest that resource loss, even in the absence of predator declines, can structure population densities and the spatial dynamics of communities. Considering how densities and habitat use patterns might change in the face of extreme events and resource declines is critical to predicting the consequences of climate change and other anthropogenic impacts on ecosystem structure and function.

Despite widespread basal resource loss, I detected no measurable effect of seagrass dieoff on the relative abundance of tiger sharks. In addition, shark catch rates retained the basic seasonal pattern of this system, with high shark densities in warm months and very low densities in most cool months. Because tiger sharks dominated the catch both before and after the die-off, this indicates that warm periods remain risky to tiger shark prey at 

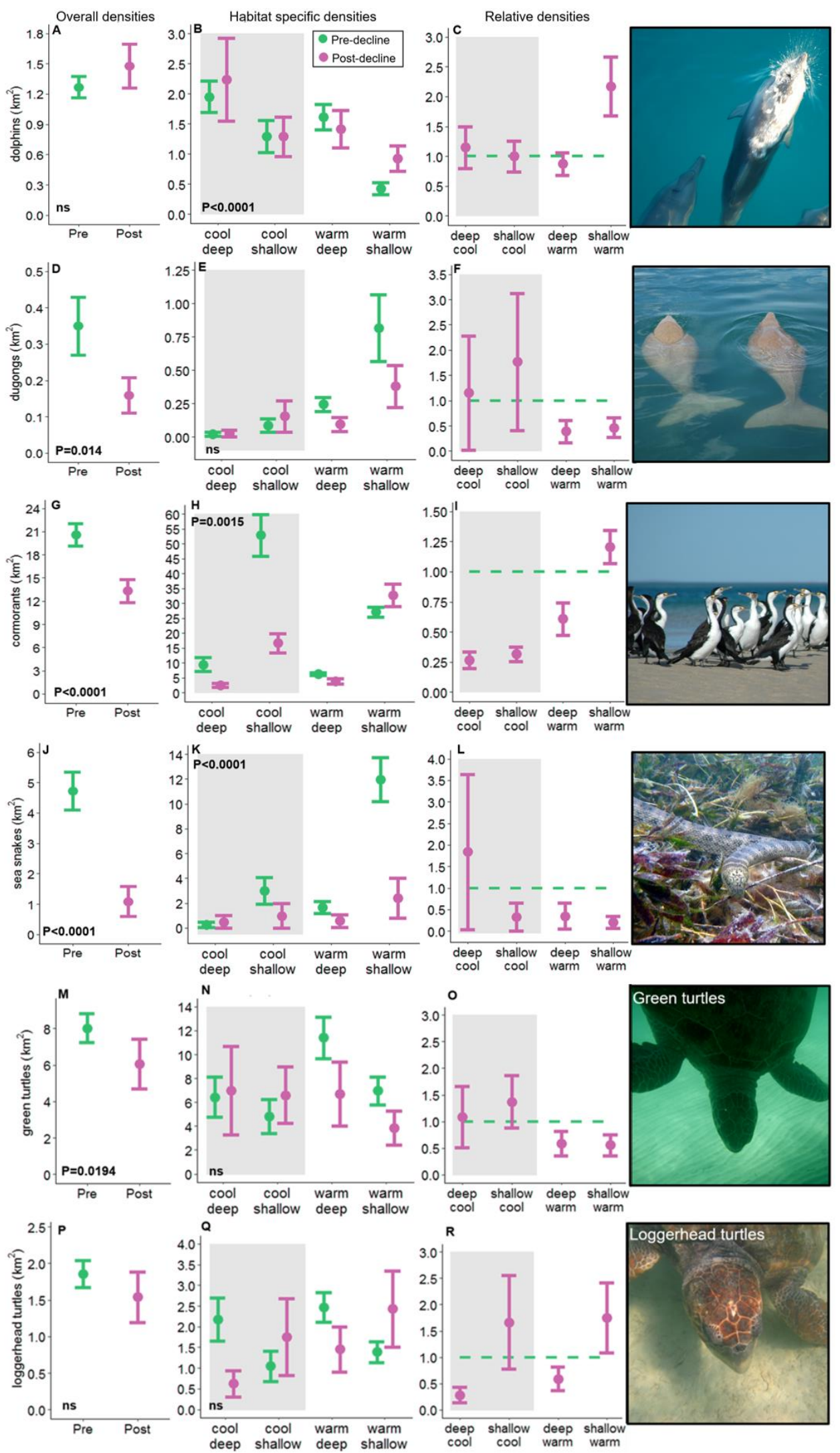

Loggerhead turtles

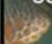


Figure 4. Changes in overall density (left column), season and habitat-specific densities (central column), and spatio-temporal shifts in habitat use patterns relative to pre-decline patterns (right column) of five groups of air-breathing megafauna in response to seagrass die-off. Significant differences are accompanied by $\mathrm{p}$ values. The cold season is shaded. In the right column, values of one represent identical densities for that habitat/season combination before and after the die-off. Seasonal habitat use patterns are considered to have shifted significantly if confidence intervals for each habitat within a season do not overlap. Error bars $=95 \%$ CI; scale bars differ in each plot. Photos: SBERP.

the ecosystem scale, while most winters remain relatively safe. Thus, the temporal pattern of predation risk that typifies this this system and drives shifts in prey habitat use patterns (Heithaus et al. 2012 and references therein) remains fundamentally unchanged despite massive resource loss.

The insensitivity of tiger sharks to widespread seagrass die-off in this system is perhaps not surprising. Tiger sharks are generalist predators at the individual level that feed on a wide variety of prey - including fish, other elasmobranchs, sea snakes, gastropods, crustaceans, birds, and marine mammals; tiger sharks also scavenge opportunistically (e.g., Matich et al. 2011, Lowe et al. 1996, Castro 2011). In addition, many individual tiger sharks that use Shark Bay range widely (Heithaus et al. 2007a). Thus, local declines in one or even several prey species are unlikely to greatly affect tiger shark populations. Indeed, loss of seagrass could actually result in short term increases in foraging success. For example, energetically stressed prey may take greater risks to obtain food (Heithaus et al. 2007b), have reduced capability to escape from predator encounters. Such a situation is possible in Shark Bay; body conditions of green turtles were significantly poorer after the die-off than before (Thomson et al. 2014). Furthermore, seagrass loss would eliminate refuges for some tiger shark prey, such as sea 
snakes (Kerford et al. 2008, Wirsing and Heithaus 2009) and has reduced water clarity (Chapter III), potentially limiting visual detection of predators.

\section{Relative abundances of mesoconsumers}

The 2011 Western Australian marine heat wave was associated with widespread changes in algae, fish and coral communities throughout Western Australia (Pearce et al. 2011, Wernberg et al. 2013, Smale and Wernberg 2013, Pearce and Feng 2013). Similarly, in Shark Bay, densities of several megafauna taxa declined significantly following seagrass loss, including sea snakes (76.9\% decline), dugongs (54.4\%), cormorants (35.4\%), and green turtles (24.4\%). Conversely, densities of loggerhead turtles and dolphins were relatively unchanged. Sea snakes and dugongs are particularly dependent on seagrass ecosystems. Dugongs are obligate seagrass herbivores (Marsh et al. 1982), while sea snakes use seagrass habitats not only to find prey, but also to hide from predators (e.g., Kerford et al. 2008, Wirsing and Heithaus 2009). While it is unclear what mechanism might drive declines in seasnakes (i.e., mortality vs emigration), several lines of evidence suggest declines in dugong densities are likely due primarily to emigration from the study system. First, dugongs respond to large-scale seagrass dieback events via large-scale movements among alternative foraging areas, with re-immigration potentially occurring quickly following disturbance as fast-growing tropical seagrasses recover (Preen and Marsh 1995, Hodgson 2007). For example, following a direct hit by category 5 cyclone Vance in 1999, which caused widespread seagrass loss, dugong densities at Ningaloo reef and Exmouth Gulf (350 km north of Shark Bay) declined heavily, while dugong populations in Shark Bay simultaneously increased by $40 \%$ 
(Gales et al. 2004, Holley et al. 2006). This increase could not be explained by reproduction alone (Gales et al. 2004). By 2006, dugong densities began to rise at Ningaloo/Exmouth, while by 2002, dugong densities in Shark Bay had returned to predisturbance levels. This pattern was concomitant with the recovery of several tropical seagrass species at Ningaloo/Exmouth on which dugongs feed (Holley 2006, Loneragan et al. 2003). Additionally, tracking data indicates dugongs are capable of migrations of hundreds of kilometers, even over short time scales (days), and appear to choose habitat based on presence of preferred seagrass food resources (Holley et al. 2006 and references therein). Furthermore, if there had been a mass mortality event, widespread dugong strandings should have been reported as happened during a mortality event in eastern Australia (Great Barrier Reef Marine Park Authority 2014). No dead, dying or stranded dugongs were encountered during thousands of hours of research, and no abnormal levels of dugong mortality or strandings were reported to local wildlife officers (Department of Parks and Wildlife, pers. comm.). This suggests that dugong densities could recover relatively quickly in Shark Bay if conditions improve with individuals returning to the system from secondary feeding locations (Hodgson 2007).

The impact of seagrass loss on sea turtle density was species-specific; densities of loggerhead turtles remained unchanged while densities of green turtles declined significantly. This is likely due, at least in part, to differences between these two species in their level of reliance on seagrass as a food resource. In the study system, loggerhead turtles are diet generalists and feed largely on benthic invertebrates and other taxa (Thomson et al. 2012), but they also will scavenge (Seney and Musick 2007). Therefore, seagrass loss might have little - or even a temporarily positive impact - on their foraging 
as refuge for benthic invertebrates is reduced. Green turtles in the system are partially reliant on seagrass as a food source, but also eat a combination of gelatinous macroplankton and benthic macroalgae (Burkholder et al. 2011, Thomson et al. 2014). While the ability to feed on macroplankton or algae might be expected to buffer green turtles from the seagrass die-off more than dugongs, it appears that individual turtles specialize on specific food, or mixes of food (Burkholder et al. 2011). Average body condition of green turtles captured following the seagrass die-off declined markedly (Thomson et al. 2014), and emaciated green turtles were found at the surface in the study system on multiple occasions between 2012 and 2015 (Nowicki pers. obs.), suggesting that mortality may be an important driver of the observed decline. Since green turtles in poor body condition take greater risks to obtain food (Heithaus et al. 2007b), and energetically stressed turtles are probably less likely to be able to escape a predator encounter, it is likely that any increases in green turtle mortality are driven by both starvation and predation.

The impact of seagrass die-off on piscivore densities also varied by species. Cormorants use seagrass habitats primarily for foraging and the $35 \%$ decline in their density may be linked to a $c a .40 \%$ reduction in the biomass of seagrass-associated fishes in the system (Heithaus 2004, Nowicki et al in prep) that they primarily forage on (Heithaus 2005). It is unclear whether density reductions are driven by birds switching to different foraging locations or mortality. Interestingly, the reduction in cormorant densities occurred mostly in the cold season (when breeding season occurs, Dell and 
Cherriman 2008), with a much smaller decline in warm period suggesting that mortality is unlikely the sole cause of changes in cormorant densities.

Unlike cormorants, dolphin densities were similar after the die-off. This may be driven by differences in foraging abilities and tendencies for dolphins to remain fairly resident in the bay. While dolphins in Shark Bay forage on seagrass-associated fishes (Heithaus and Dill 2002), they also forage in deeper habitats (e.g., Sargeant et al. 2007) and stable isotopic values indicate that dolphins may derive a substantial amount of their energy from plankton- or macroalgae-associated food webs (Heithaus et al. 2013).

Second, dolphins are larger-bodied with greater energy stores than cormorants, potentially reducing their vulnerability to starvation mortality or need to emigrate. Third, dolphins may be less likely to emigrate from the study system than cormorants because the former have relatively stable home ranges and inter-individual social bonds which likely play critical roles in reproductive success and fitness (e.g., Smolker et al. 1992, Connor et al. 2001, Krutzen and Sherwin 2004). Therefore, dolphins are likely to remain in the system as long as adequate resources are available.

\section{Effects on mesoconsumer habitat use patterns}

The proportion of dolphins and cormorants that used risky but relatively profitable shallow seagrass banks during periods when tiger sharks were abundant was greater after the die-off than before it. This pattern is consistent with individuals taking greater risks to obtain higher foraging rewards after the onset of resource (seagrass and fish) declines. The sea snake habitat use model indicated significant shifts in habitat use since the die-off, but the biological significance of this result is unclear. Given the 
magnitude of sea snake decline, and the extremely low frequency of sea snake sightings in deep habitats (particularly in the cold season), it may not be possible to reliably infer shifts in sea snake habitat use patterns with the methods described here.

Loggerhead turtles increased their relative use of shallow habitats in both low-risk and high-risk periods after the seagrass decline. This may reflect enhanced foraging success in newly denuded shallow banks. Indeed, loggerhead turtles in Shark Bay are most commonly found, and appear to forage most often, in un-vegetated habitats where they can locate and consume both epibenthic and infaunal invertebrates (Thomson et al. 2012). Unfortunately, data on loggerhead prey distributions or post die-off foraging success are not available to test this hypothesis.

Like loggerhead turtles, green turtles did not show significant changes habitat use patterns. Instead, green turtle densities declined in both deep and shallow habitats during warm seasons. This was somewhat surprising because green turtle body conditions were substantially lower after the seagrass die-off (Thomson et al. 2014); before the seagrass die-off, green turtles in poor body condition foraged further into shallow seagrass banks than green turtles in good body condition when tiger sharks are abundant, illustrating that such condition-dependent risk taking by green turtles does occur in this system (Heithaus et al. 2007b).

Several factors may explain the apparent lack of increased risk taking by energetically stressed green turtles at the population level when it is known to exist at the individual level. As diet specialists in this system (Burkholder et al. 2011), green turtles with seagrass heavy diets may have been disproportionately impacted by the die-off, 
reducing the proportion of individuals that must enter shallow habitats to feed.

Alternatively, turtles that previously specialized on seagrass may have switched to other food sources which are not necessarily more common in shallow habitats (i.e., gelatinous macroplankton). Finally, since feeding on gelatinous macroplankton occurs in the water column instead of on the benthos (Heithaus et al. 2002, Thomson and Heithaus 2014), and sea turtles reduce air volume to remain submerged at shallower depths (e.g., Hays et al. 2004), shifts in foraging tactics may drive differences in diving behavior and availability bias, even if habitat use patterns remain unchanged. Clearly, further study on the implications of resource loss for green turtle populations, diets, and behavior is needed.

More generally, several alternative hypotheses, which I consider less likely, could drive the observed patterns of risk-sensitive habitat use in this study. First, while seagrass loss was extensive throughout the study area, it is possible that the relative concentration of food resources into shallow habitats versus deep habitats has strengthened, not weakened, since the die-off. If true, shifts in habitat use by some tiger shark prey could be driven by a change in the food landscape instead of by increased risktaking by tiger shark prey. However, this is unlikely for most species, with the potential exception of loggerhead turtles. For piscivorous species (cormorants, sea snakes, dolphins), including those in which shifts in risk-sensitive habitat use were observed, declines in fish biomass were stronger in shallow (c.a. $40 \%$ decline) than deep habitats (c.a. $27 \%$ decline, Nowicki et al. in preparation). Therefore, if resource availability were the primary driver of shifts in dolphins and cormorants, relative use of shallow habitats should decline, not increase (as was observed). 
Though tiger shark abundance has not changed, the patterns consistent with increased risk taking could potentially be driven by spatial shifts in tiger shark habitat use patterns within the study system. Shark fishing in shallow habitats was not possible because of logistical constraints (e.g., high rates of bait loss, Heithaus 2001). Video tracking of sharks before the die-off revealed that tiger sharks spend more time in shallow than deep habitats (Heithaus et al 2002, Heithaus et al. 2006). With the increased use of shallow habitats by known prey described here, it seems unlikely that tiger sharks would reverse previous habitat preferences to prefer deep habitats. Even if tiger sharks have shifted to using shallow habitats less frequently (and reducing shark encounter rates experienced by prey), chance of encounter is only one component of predation risk (Lima and Dill 1990, Heithaus et al. 2009). Indeed, shallow habitats carry higher intrinsic risk (i.e., probability of death in an encounter situation) for dugongs (Wirsing et al. 2007), dolphins (Heithaus and Dill 2002, 2006), and green turtles (Heithaus et al. 2007b) by reducing vertical maneuverability potential (and thus escape probability). It is thus likely that shallow habitats remain more dangerous than deep habitats for tiger shark prey, and that the observed shifts in relative densities of dolphins, cormorants, and sea snakes is driven by increased risk-taking by these species.

\section{Ecological implications}

Extreme climactic events are predicted to occur with increased frequency as climate change continues (Easterling et al. 2000, IPCC 2014), and species interactions are likely to play an important role in determining how ecosystems respond (Zarnetske et al. 2012, Taylor et al. 2015). It is therefore critical to develop a better understanding of the 
impact that such events, as well as their biotic interactions, will have on ecosystems (Thomson et al. 2014). Apex predators may act as particularly important biotic multipliers of climate change (sensu Zarnetske et al. 2012) in part because of their large number of species interactions and their ability to generate trophic cascades through direct predation, risk effects, and the interaction of the two. Appropriately, there has been a focus on determining the ecological role of marine apex predators in the context of global apex predator declines (e.g., Ferreti et al. 2010), with the goal of developing a predictive framework for the ecological consequences of marine top predator declines (e.g., Heithaus et al. 2008, 2009). However, factors other than predator presence or density, such as condition-dependent habitat use by prey, can also alter the strength of top-down and bottom up disruptions to ecosystems as prey must take risks to meet energetic demands (Heithaus et al. 2008). Resource declines in particular are predicted to shift the mechanisms through which top-down processes occur. As resource limitation increases and risk-sensitive habitat use patterns of energetically stressed prey change, consumptive effects of predators should become relatively more important than nonconsumptive (risk) effects (Heithaus et al. 2008). The behaviors observed in the study are consistent with this trend toward increased risk-taking that should increase consumptive effects of predators.

\section{Conclusions}

To my knowledge, this is the first study to investigate the effects of resource decline on anti-predator behavior of such a wide variety of consumers at the ecosystem scale. Given the wide-spread nature of condition-dependent risk taking in oceans and on 
land (e..g wildebeest, Connochaetes taurinus, Sinclair \& Arcese 1995; Redshanks, Tringa totanus, Yasue et al. 2003) it is important that resource loss, not only predator loss, is explicitly considered as a factor mediating anti-predator behavior at population and ecosystem scales. This includes evaluating the potential for resource loss to alter the strength of behavior-mediated trophic cascades. Inclusion of resource loss into a predictive framework for predator risk effects (see Heithaus et al. 2008) is valuable in predicting the impacts of both predator losses and system-wide disturbances to ecosystems as both local and global stressors (e.g., eutrophication, overfishing, climate change) continue.

\section{Acknowledgements}

I would like to acknowledge the critical assistance of field crews including J. Olson, A. Macy, R. Sarabia, J. Johnson, N. Norton, A. Morgan, K. Gastrich, M. Jew, T. Code, H. Neutzel, and C. Morgan. I would also like to thank the people of Monkey Mia Dolphin Resort and Shark Bay for considerable logistical support. Funding was provided by an NSF Rapid Response grant awarded to MRH, an NSF Graduate Research Fellowship awarded to RJN, an FIU Dissertation Year Fellowship to RJN, a PADI foundation award to RJN, and donations from the public.

\section{Literature Cited}

Anholt, B.R. \& Werner, E.E. (1995). Interaction between food availability and predation mortality mediated by adaptive behavior. Ecology, 76, 2230-2234.

Bates, D., Maechler, M., Bolker, B. \& Walker, S. (2015). Fitting Linear Mixed-Effects Models Using lme4. Journal of Statistical Software, 67, 1-48. 
Beauchamp, G. \& Ruxton, G.D. (2011). A reassessment of the predation risk allocation hypothesis: a comment on Lima and Bednekoff. The American Naturalist, 177, 143-146.

Bessey, C. (2013). The Role of Teleost Grazers in a Relatively Pristine Seagrass Ecosystem.

Biro, P.A., Post, J.R. \& Abrahams, M.V. (2005). Ontogeny of energy allocation reveals selective pressure promoting risk-taking behaviour in young fish cohorts. Proceedings of the Royal Society of London B: Biological Sciences, 272, 14431448.

Burkholder, D.A., Fourqurean, J.W. \& Heithaus, M.R. (2013a). Spatial pattern in seagrass stoichiometry indicates both $\mathrm{N}$-limited and P-limited regions of an iconic P-limited subtropical bay. Marine Ecology Progress Series, 472, 101-115.

Burkholder, D.A., Heithaus, M.R., Fourqurean, J.W., Wirsing, A. \& Dill, L.M. (2013b). Patterns of top-down control in a seagrass ecosystem: could a roving apex predator induce a behaviour-mediated trophic cascade? Journal of Animal Ecology, 82, 1192-1202.

Burkholder, D.A., Heithaus, M.R., Thomson, J.A. \& Fourqurean, J.W. (2011). Diversity in trophic interactions of green sea turtles Chelonia mydas on a relatively pristine coastal foraging ground. Marine Ecology Progress Series, 439, 277-293.

Burnham, K.P. \& Anderson, D.R. (2004). Multimodel inference understanding AIC and BIC in model selection. Sociological methods \& research, 33, 261-304.

Cai W, Borlace S, Lengaigne M, Van Rensch P, Collins M, Vecchi G, Timmermann A, Santoso A, McPhaden MJ, Wu L, England MH, Wang G, Guilyardi E, Jin, F. (2014) Increasing frequency of extreme El Niño events due to greenhouse warming. Nature Climate Change 4:111-116

Cai W, Wang G, Santoso A, McPhaden MJ, Wu L, Jin F-F, Timmermann A, Collins M, Vecchi G, Lengaigne M, England MH, Dommenget D, Takahashi K, Guilyardi E (2015) Increased frequency of extreme La Niña events under greenhouse warming. Nature Clim Change 5:132-137

Castro, J.I. (2010). The sharks of North America. Oxford University Press.

Clark, C.W. (1994). Antipredator behavior and the asset-protection principle. Behavioral Ecology, 5, 159-170. 
Connor, R.C., Heithaus, M.R. \& Barre, L.M. (2001). Complex social structure, alliance stability and mating access in a bottlenose dolphin "super-alliance." Proceedings of the Royal Society of London B: Biological Sciences, 268, 263-267.

Costanza, R., d'Arge, R., De Groot, R., Faber, S., Grasso, M., Hannon, B., et al. (1997). The value of the world's ecosystem services and natural capital.

Creel, S. \& Christianson, D. (2008). Relationships between direct predation and risk effects. Trends in Ecology \& Evolution, 23, 194-201.

Creel, S., Christianson, D.A. \& Winnie, J.A. (2011). A survey of the effects of wolf predation risk on pregnancy rates and calf recruitment in elk. Ecological Applications, 21, 2847-2853.

Creel, S. \& Winnie, J.A. (2005). Responses of elk herd size to fine-scale spatial and temporal variation in the risk of predation by wolves. Animal Behaviour, 69, $1181-1189$.

Dell, J. \& Cherriman, S. (2008). The birds of Faure Island, Shark Bay, Western Australia. Records of the Western Australian lvluscul11 Supplement No, 75, 70.

Department of Environment and Conservation. (2008). Shark Bay World Heritage Property strategic plan, 2008-2020. Perth, Western Australia.

Dill, L.M., Heithaus, M.R. \& Walters, C.J. (2003). Behaviorally mediated indirect interactions in marine communities and their conservation implications. Ecology, $84,1151-1157$.

Dunn, P. (2014). tweedie: Tweedie exponential family models.

Easterling, D.R., Meehl, G.A., Parmesan, C., Changnon, S.A., Karl, T.R. \& Mearns, L.O. (2000). Climate extremes: observations, modeling, and impacts. science, 289, 2068-2074.

Ferretti, F., Worm, B., Britten, G.L., Heithaus, M.R. \& Lotze, H.K. (2010). Patterns and ecosystem consequences of shark declines in the ocean. Ecology letters, 13, $1055-1071$.

Fourqurean, J.W., Duarte, C.M., Kennedy, H., Marbà, N., Holmer, M., Mateo, M.A., et al. (2012). Seagrass ecosystems as a globally significant carbon stock. Nature Geoscience, 5, 505-509.

Fraser, M.W., Kendrick, G.A., Statton, J., Hovey, R.K., Zavala-Perez, A. \& Walker, D.I. (2014). Extreme climate events lower resilience of foundation seagrass at edge of biogeographical range. Journal of Ecology, 102, 1528-1536. 
Fretwell, S.D. \& Lucas Jr., H.J. (1970). On territorial behaviour and other factors influencing habitat distribution of birds. Acta biotheoretica, 19, 19-36.

Frid, A., Marliave, J. \& Heithaus, M.R. (2012). Interspecific variation in life history relates to antipredator decisions by marine mesopredators on temperate reefs. PloS one, 7.

Gales, N., McCauley, R.D., Lanyon, J. \& Holley, D. (2004). Change in abundance of dugongs in Shark Bay, Ningaloo and Exmouth Gulf, Western Australia: evidence for large-scale migration. Wildlife Research, 31, 283-290.

Giner, G. \& Smyth, G. (2016). statmod: probability calculations for the inverse Gaussian distribution. R Journal.

Great Barrier Reef Marine Park Authority. (2014). Great Barrier Reef Outlook Report 2014. Australian Government.

Hays, G.C., Metcalfe, J.D. \& Walne, A.W. (2004). The implications of lung-regulated buoyancy control for dive depth and duration. Ecology, 85, 1137-1145.

Heck Jnr, K.L., Hays, G. \& Orth, R.J. (2003). Critical evaluation of the nursery role hypothesis for seagrass meadows. Marine Ecology Progress Series, 253, 123-136.

Heithaus, M.R. (2001). The biology of tiger sharks, Galeocerdo cuvier, in Shark Bay, Western Australia: sex ratio, size distribution, diet, and seasonal changes in catch rates. Environmental Biology of Fishes, 61, 25-36.

Heithaus, M.R., McLash, J.J., Frid, A., Dill, L.M. \& Marshall, G.J. (2002). Novel insights into green sea turtle behaviour using animal-borne video cameras. Journal of the Marine Biological Association of the UK, 82, 1049-1050.

Heithaus, M.R. (2004). Fish communities of subtropical seagrass meadows and associated habitats in Shark Bay, Western Australia. Bulletin of Marine Science, 75, 79-99.

Heithaus, M.R. (2005). Habitat use and group size of Piedcormorants (Phalacrocorax varius) in a seagrass ecosystem: possible effects of food abundance and predation risk. Marine Biology, 147, 27-35.

Heithaus, M.R., Dill, L.., Marshall, G.J. \& Buhleier, B. (2002). Habitat use and foraging behavior of tiger sharks (Galeocerdo cuvier) in a seagrass ecosystem. Marine Biology, 140, 237-248. 
Heithaus, M.R., Hamilton, I.M., Wirsing, A.J. \& Dill, L.M. (2006). Validation of a randomization procedure to assess animal habitat preferences: microhabitat use of tiger sharks in a seagrass ecosystem. Journal of Animal Ecology, 75, 666-676.

Heithaus, M.R. \& Dill, L.M. (2002). Food availability and tiger shark predation risk influence bottlenose dolphin habitat use. Ecology, 83, 480-491.

Heithaus, M.R. \& Dill, L.M. (2006). Does tiger shark predation risk influence foraging habitat use by bottlenose dolphins at multiple spatial scales? Oikos, 114, 257264.

Heithaus, M.R., Wirsing, A.J., Dill, L.M. \& Heithaus, L.I. (2007a). Long-term movements of tiger sharks satellite-tagged in Shark Bay, Western Australia. Marine Biology, 151, 1455-1461.

Heithaus, M.R., Frid, A., Wirsing, A.J., Dill, L.M., Fourqurean, J.W., Burkholder, D., et al. (2007b). State-dependent risk-taking by green sea turtles mediates top-down effects of tiger shark intimidation in a marine ecosystem. Journal of Animal Ecology, 76, 837-844.

Heithaus, M.R., Frid, A., Wirsing, A.J. \& Worm, B. (2008). Predicting ecological consequences of marine top predator declines. Trends in Ecology \& Evolution, $23,202-210$.

Heithaus, M.R., Wirsing, A.J., Burkholder, D., Thomson, J. \& Dill, L.M. (2009). Towards a predictive framework for predator risk effects: the interaction of landscape features and prey escape tactics. Journal of Animal Ecology, 78, 556562.

Heithaus, M.R., Wirsing, A.J. \& Dill, L.M. (2012). The ecological importance of intact top-predator populations: a synthesis of 15 years of research in a seagrass ecosystem. Marine and Freshwater Research, 63, 1039-1050.

Hodgson, A. (2007). The distribution, abundance and conservation of dugongs and other marine megafauna in Shark Bay Marine Park, Ningaloo Reef Marine Park and Exmouth Gulf. Department of Environment and Conservation.

Holley, D. (2006). Movement patterns and habitat usage of Shark Bay dugongs. Edith Cowan University.

Jeffries, M.J. \& Lawton, J.H. (1984). Enemy free space and the structure of ecological communities. Biological Journal of the Linnean Society, 23, 269-286.

Jones, C.G., Lawton, J.H. \& Shachak, M. (1994). Organisms as ecosystem engineers. In: Ecosystem management. Springer, pp. 130-147. 
Kerford, M.R., Wirsing, A.J., Heithaus, M.R. \& Dill, L.M. (2008). Danger on the rise: diurnal tidal state mediates an exchange of food for safety by the bar-bellied sea snake Hydrophis elegans. Marine Ecology Progress Series, 358, 289-294.

Krützen, M., Sherwin, W.B., Berggren, P. \& Gales, N. (2004). Population structure in an inshore cetacean revealed by microsatellite and mtDNA analysis: bottlenose dolphins (Tursiops sp.) in Shark Bay, Western Australia. Marine Mammal Science, 20, 28-47.

Lima, S.L. (1998). Stress and decision making under the risk of predation: recent developments from behavioral, reproductive, and ecological perspectives. Advances in the Study of Behavior, 27, 215-290.

Lima, S.L. \& Bednekoff, P.A. (1999). Temporal variation in danger drives antipredator behavior: the predation risk allocation hypothesis. The American Naturalist, 153, 649-659.

Lima, S.L. \& Dill, L.M. (1990). Behavioral decisions made under the risk of predation: a review and prospectus. Canadian Journal of Zoology, 68, 619-640.

Loneragan, N., Kenyon, R., Crocos, P., Ward, R., Lehnert, S., Haywood, M., et al. (2003). Developing techniques for enhancing prawn fisheries, with a focus on brown tiger prawns (Panaeus esculentus) in Exmouth Gulf. Final Report on FRDC Project 1999/222. CSIRO, Cleveland.

Lowe, C.G., Wetherbee, B.M., Crow, G.L. \& Tester, A.L. (1996). Ontogenetic dietary shifts and feeding behavior of the tiger shark, Galeocerdo cuvier, in Hawaiian waters. Environmental Biology of Fishes, 47, 203-211.

Marsh, H., Channells, P.W., Heinsohn, G.E. \& Morrissey, J. (1982). Analysis of Stomach Contents of Dugongs From Queensland. Wildlife Research, 9, 55-67.

Matich, P. \& Heithaus, M.R. (2012). Effects of an extreme temperature event on the behavior and age structure of an estuarine top predator, Carcharhinus leucas. Marine Ecology Progress Series, 447.

Matich, P. \& Heithaus, M.R. (2015). Individual variation in ontogenetic niche shifts in habitat use and movement patterns of a large estuarine predator (Carcharhinus leucas). Oecologia, 178, 347-359.

Matich, P., Heithaus, M.R. \& Layman, C.A. (2011). Contrasting patterns of individual specialization and trophic coupling in two marine apex predators. Journal of Animal Ecology, 80, 294-305. 
McNamara, J.M. \& Houston, A.I. (1990). The value of fat reserves and the tradeoff between starvation and predation. Acta biotheoretica, 38, 37-61.

Nowicki, R.J. \& Heithaus, M.R. (In prep). Seagrass functional redundancy and differential environmental tolerance mediates response of teleost community to catastrophic seagrass loss.

Nowicki, R.J., Thomson, J.A., Burkholder, D.A. \& Fourqurean, J.W. (In review). Predicting seagrass recovery trajectories and their implications following an extreme climate event. Marine Ecology Progress Series.

Orth, R.J., Carruthers, T.J., Dennison, W.C., Duarte, C.M., Fourqurean, J.W., Heck, K.L., et al. (2006). A global crisis for seagrass ecosystems. Bioscience, 56, 987-996.

Pachauri, R.K., Allen, M.R., Barros, V.R., Broome, J., Cramer, W., Christ, R., et al. (2014). Climate change 2014: synthesis Report. Contribution of working groups I, II and III to the fifth assessment report of the intergovernmental panel on climate change. IPCC.

Pearce, A.F. \& Feng, M. (2013). The rise and fall of the "marine heat wave" off Western Australia during the summer of 2010/2011. Journal of Marine Systems, 111, 139156.

Pearce, A.F., Lenanton, R., Jackson, G., Moore, J., Feng, M. \& Gaughan, D. (2011). The "marine heat wave" off Western Australia during the summer of 2010/11. Western Australian Fisheries and Marine Research Laboratories.

Pinheiro, J., Bates, D., DebRoy, S., Sarkar, D. \& R Core Team. (2016). nlme: Linear and Nonlinear Mixed Effects Models.

Preen, A. \& Marsh, H. (1995). Response of dugongs to large-scale loss of seagrass from Hervey Bay, Queensland, Australia. Wildlife Research, 22, 507-519.

Preisser, E.L., Orrock, J.L. \& Schmitz, O.J. (2007). Predator hunting mode and habitat domain alter nonconsumptive effects in predator-prey interactions. Ecology, 88, 2744-2751.

Ripple, W.J. \& Beschta, R.L. (2004). Wolves and the ecology of fear: can predation risk structure ecosystems? BioScience, 54, 755-766.

RStudio Team. (2015). RStuido: Integrated Development for R. RStudio, Inc., Boston, MA. 
Sargeant, B.L., Wirsing, A.J., Heithaus, M.R. \& Mann, J. (2007). Can environmental heterogeneity explain individual foraging variation in wild bottlenose dolphins (Tursiops sp.)? Behavioral Ecology and Sociobiology, 61, 679-688.

Schmitz, O.J., Beckerman, A.P. \& O’Brien, K.M. (1997). Behaviorally mediated trophic cascades: effects of predation risk on food web interactions. Ecology, 78, 13881399.

Seney, E.E. \& Musick, J.A. (2007). Historical diet analysis of loggerhead sea turtles (Caretta caretta) in Virginia. Copeia, 2007, 478-489.

Short, F.T. \& Wyllie-Echeverria, S. (1996). Natural and human-induced disturbance of seagrasses. Environmental conservation, 23, 17-27.

Simpfendorfer, C. (1992). Biology of Tiger Sharks (Galeocerdo cuvier) caught by the Queensland Shark Meshing Program off Townsville, Australia. Mar. Freshwater Res.,43, 33-43.

Simpfendorfer, C.A., Goodreid, A.B. \& McAuley, R.B. (2001). Size, Sex And Geographic Variation in the Diet of the Tiger Shark, Galeocerdo Cuvier, From Western Australian Waters. Environmental Biology of Fishes, 61, 37-46.

Sinclair, A.R.E. \& Arcese, P. (1995). Population consequences of predation-sensitive foraging: The Serengeti wildebeest. Ecology, 76, 882-891.

Sinclair, A.R.E. \& Pech, R.P. (1996). Density dependence, stochasticity, compensation and predator regulation. Oikos, 164-173.

Smale, D.A. \& Wernberg, T. (2013). Extreme climatic event drives range contraction of a habitat-forming species. In: Proc. R. Soc. B. The Royal Society.

Smolker, R.A., Richards, A.F., Connor, R.C. \& Pepper, J.W. (1992). Sex differences in patterns of association among Indian Ocean bottlenose dolphins. Behaviour, 123, $38-69$.

Stevens, J. \& McLoughlin, K. (1991). Distribution, size and sex composition, reproductive biology and diet of sharks from Northern Australia. Mar. Freshwater Res., 42, 151-199.

Taylor, S.A., Larson, E.L. \& Harrison, R.G. (2015). Hybrid zones: windows on climate change. Trends in ecology \& evolution, 30, 398-406.

Thomson, J., Cooper, A., Burkholder, D., Heithaus, M. \& Dill, L. (2012.). Heterogeneous patterns of availability for detection during visual surveys: spatiotemporal 
variation in sea turtle dive-surfacing behaviour on a feeding ground. Methods in Ecology and Evolution, 3, 378-387.

Thomson, J.A., Cooper, A.B., Burkholder, D.A., Heithaus, M.R. \& Dill, L.M. (2013). Correcting for heterogeneous availability bias in surveys of long-diving marine turtles. Biological Conservation, 165, 154-161.

Thomson, J.A., Burkholder, D.A., Heithaus, M.R., Fourqurean, J.W., Fraser, M.W., Statton, J., et al. (2014). Extreme temperatures, foundation species, and abrupt ecosystem change: an example from an iconic seagrass ecosystem. Global change biology, 21, 1463-1474.

Thomson, J.A., Heithaus, M.R., Burkholder, D.A., Vaudo, J.J., Wirsing, A.J. \& Dill, L.M. (2012). Site specialists, diet generalists? Isotopic variation, site fidelity, and foraging by loggerhead turtles in Shark Bay, Western Australia. Marine Ecology Progress Series, 453, 213-226.

Thomson, J.A. \& Heithaus, M.R. (2014). Animal-borne video reveals seasonal activity patterns of green sea turtles and the importance of accounting for capture stress in short-term biologging. Journal of Experimental Marine Biology and Ecology, 450, 15-20.

Walker, D.I. (1985). Correlations between salinity and growth of the seagrass Amphibolis antarctica (Labill.) Sonder \& Aschers., in Shark Bay, Western Australia, using a new method for measuring production rate. Aquatic botany, 23, 13-26.

Walker, D.I., Kendrick, G.A. \& McComb, A.J. (1988). The distribution of seagrass species in Shark Bay, Western Australia, with notes on their ecology. Aquatic Botany, 30, 305-317.

Walker, D.I. \& McComb, A.J. (1988). Seasonal variation in the production, biomass and nutrient status of Amphibolis antarctica (Labill.) Sonder ex Aschers. and Posidonia australis Hook. f. in Shark Bay, Western Australia. Aquatic botany, 31, 259-275.

Warner, R.R. (1998). The role of extreme iteroparity and risk avoidance in the evolution of mating systems. Journal of Fish Biology, 53, 82-93.

Waycott, M., Duarte, C.M., Carruthers, T.J., Orth, R.J., Dennison, W.C., Olyarnik, S., et al. (2009). Accelerating loss of seagrasses across the globe threatens coastal ecosystems. Proceedings of the National Academy of Sciences, 106.

Wernberg, T., Smale, D.A., Tuya, F., Thomsen, M.S., Langlois, T.J., De Bettignies, T., et al. (2013). An extreme climatic event alters marine ecosystem structure in a global biodiversity hotspot. Nature Climate Change, 3, 78-82. 
Werner, E.E. \& Peacor, S.D. (2003). A review of trait-mediated indirect interactions in ecological communities. Ecology, 84, 1083-1100.

Wirsing, A.J., Cameron, K.E. \& Heithaus, M.R. (2010). Spatial responses to predators vary with prey escape mode. Animal Behaviour, 79, 531-537.

Wirsing, A.J. \& Heithaus, M.R. (2009). Olive-headed sea snakes Disteria major shift seagrass microhabitats to avoid shark predation. Marine Ecology Progress Series, 387, 287-293.

Wirsing, A.J., Heithaus, M.R. \& Dill, L.M. (2006). Tiger shark (Galeocerdo cuvier) abundance and growth in a subtropical embayment: evidence from 7 years of standardized fishing effort. Marine Biology, 149, 961-968.

Wirsing, A.J., Heithaus, M.R. \& Dill, L.M. (2007b). Fear factor: do dugongs (Dugong dugon) trade food for safety from tiger sharks (Galeocerdo cuvier)? Oecologia, 153, 1031-1040.

Wirsing, A.J., Heithaus, M.R. \& Dill, L.M. (2007). Living on the edge: dugongs prefer to forage in microhabitats that allow escape from rather than avoidance of predators. Animal Behaviour, 74, 93-101.

Wood, S.N. (2011). Fast stable restricted maximum likelihood and marginal likelihood estimation of semiparametric generalized linear models. Journal of the Royal Statistical Society (B), 73, 3-36.

Wu, L., Cai, W., Zhang, L., Nakamura, H., Timmermann, A., Joyce, T., et al. (2012). Enhanced warming over the global subtropical western boundary currents. Nature Climate Change, 2, 161-166.

Yasué, M., Quinn, J.L. \& Cresswell, W. (2003). Multiple effects of weather on the starvation and predation risk trade-off in choice of feeding location in Redshanks. Functional Ecology, 17, 727-736.

Zarnetske, P.L., Skelly, D.K. \& Urban, M.C. (2012). Biotic multipliers of climate change. Science, 336, 1516-1518.

Zuur, A.F., Ieno, E.N., Walker, N.J., Saveliev, A.A. \& Smith, G.M. (2009). Mixed effects models in ecology with R. Springer, Berlin. 


\section{CHAPTER V}

\section{SIMULATED LOSS OF PREDATION RISK GENERATED BY APEX PREDATORS}

INTENSIFIES ECOSYSTEM IMPACTS OF AN EXTREME CLIMATE EVENT 


\begin{abstract}
Understanding how multiple stressors interact to impact ecosystems in the context of climate change is paramount. In particular, biotic factors such as species interactions likely mediate how ecosystems respond to climate change. Apex predators generally interact with many species in their ecosystems and are thought to enhance ecosystem stability and function. Therefore, loss of apex predators may leave systems more susceptible to acute climate extremes. Despite the widespread co-occurrence of apex predator losses and disturbances from extreme climate events across multiple ecosystem types, we have a poor understanding of if, when, and how these stressors interact to influence ecosystems. Here, I describe the results of a field experiment to determine whether loss of an apex marine predator, the tiger shark (Galeocerdo cuvier), might exacerbate effects of a recent extreme "marine heat wave" in a subtropical seagrass ecosystem. Predator losses were simulated using diver-applied grazing treatments consistent with previously documented shifts in risk-sensitive foraging patterns of megagrazers (Dugong dugon). Temperate late successional seagrasses declined in grazing treatments but remained stable in control plots, while early successional tropical seagrasses declined irrespective of grazing treatment. This resulted in losses of structural complexity in grazing plots but not in control plots. My results suggest that tiger sharks stabilize disturbed seagrass habitats, providing critical recovery time for high-value seagrass beds following major climactic disturbance. More generally, the widespread loss of apex predators on land and in oceans may amplify the effects of climate disturbance to habitat-forming species across diverse ecosystems and large spatial scales.
\end{abstract}




\section{Introduction}

As extreme climactic events associated with anthropogenic climate change are becoming more frequent and intense (e.g., Easterling et al. 2000, Pachauri et al. 2014, Cai et al. 2014, 2015), the need to assess the impact of these events on ecosystems has become critical. Warming and extreme events, however, do not occur in isolation and multiple stressors, both biotic and abiotic, can widely co-occur, potentially interacting to generate emergent ecosystem responses (e.g., Harley and Paine 2009, Harley 2011, Zarnetzke et al. 2012, Crain et al. 2008). It is crucial, therefore, to understand when and how these combinations of stressors might interact to impact ecosystems (Mineur et al. 2014).

Species interactions are likely to have important roles in determining how ecosystems respond to climate change (Zarnetske et al. 2012, Taylor et al. 2015). One of the most critical and widespread biotic changes to species interactions globally is the anthropogenically-mediated loss of apex predators (e.g., Ferretti et al. 2010, Estes et al. 2011, 2016, Ripple et al. 2014). Apex predator loss may act as a particularly important biotic multiplier of climate change (sensu Zarnetske et al. 2012) because of their large number of species interactions, low functional redundancy, and disproportionate vulnerability to exploitation (Jeffries and Lawton 1984, Schindler 1990, Heithaus et al. 2008). Despite the potentially powerful nature and likely widespread co-occurrence of apex predator losses with climate extremes, the potential that top predator loss amplifies effects of extreme events or facilitates ecosystem phase shifts is poorly understood (Harley et al. 2006, Richardson and Poloczanska 2008). 
Trophic cascades induced by the loss of top predators have been widely documented (e.g., Daskalov 2007, Heithaus et al. 2008, Estes et al. 2011, Ripple et al. 2014). While such cascades can be the result of relaxed predation rates on prey, they can also operate exclusively through non-consumptive mechanisms ("risk effects") and the interaction of consumptive and non-consumptive effects (e.g., Werner and Peacor 2003, Presser et al. 2005, Heithaus et al. 2008). Loss of top predators can also lead to changes in ecosystem function (e.g., Schmitz et al. 2008, Estes et al. 2011) and, in marine systems may lead to reduction of stores of carbon sequestered in seagrass, mangrove, and marsh habitats ("blue carbon;" Atwood et al. 2015). Maintenance of trophic cascades, particularly those that suppress herbivores, may be critical following large climactic disturbances to primary producer communities. Despite much research about the effects of predator removal on trophic cascades, the impacts of apex predator loss on ecosystem stability are still not well understood (Britten et al. 2014) and experimental work evaluating this relationship is particularly lacking.

To assess whether the loss of apex predators can cause emergent effects when combined with climactic disturbance, I performed a 16 month field experiment in the subtropical seagrass ecosystem of Shark Bay, Australia after a natural extreme climatic disturbance. Shark Bay $\left(25^{\circ} 25^{\prime} \mathrm{S}, 113^{\circ} 44^{\prime} \mathrm{E}\right)$ is a shallow $(<15 \mathrm{~m}), 13,000 \mathrm{~km}^{2}$ semienclosed subtropical embayment approximately $800 \mathrm{~km}$ north of Perth, Western Australia. The bay historically contained over $4000 \mathrm{~km}^{2}$ of seagrass, $85 \%$ of which was dominated by the temperate seagrass Amphibolis antarctica, which is at the tropical limit of its range in Shark Bay (Walker et al. 1988). Amphibolis antarctica is an ecosystem engineer (sensu Jones et al. 1994) that forms dense, continuous beds that greatly increase 
benthic structure, stabilize sediment, provide food to fauna (largely through the production of epiphytes), and provide greater carbon storage than species of tropical origin in the system (Walker et al. 1988, Borowitzka et al. 2006, Burkholder et al. 2013a, Atwood et al. 2015). The most common tropical seagrass in the bay is Halodule uninervis (Burkholder et al. 2013a), a much smaller and structurally simpler species. Seagrasses in Shark Bay are grazed by large populations of green sea turtles (Chelonia mydas) and dugongs (Dugong dugon) which are at risk of predation from a largely intact population of tiger sharks (Galeocerdo cuvier)- risk which alters behavior in these species and triggers a behaviorally-mediated trophic cascade (or BMTC, Heithaus et al. 2012 and references therein, Burkholder et al. 2013b).

Over 15 years of research on BMTCs in Shark Bay has taken advantage of interannual and seasonal variation in predation risk from tiger sharks (see Heithaus et al. 2012). A combination of manipulative and "natural" experiments have shown that tiger shark presence induces shifts in megaherbivore distribution and foraging tactics that facilitates the formation and persistence of dense, high-biomass, beds of A. antarctica in dangerous shallow waters and lower biomass beds of fast-growing species in safer habitats (Heithaus et al. 2012, Burkholder et al. 2013b, Figure 1a). Beds in safer habitats also feature greater carbon storage capacity (Atwood et al. 2015). Based on these studies, and those in other locations (e.g., Preen 1995), it is possible that megaherbivores released from shark predation risk may generate a regime-shift to a low-biomass, low carbon-storage, system even in previously dangerous habitats. Because A. antarctica is of low nutritional value to herbivores (Burkholder et al. 2012) and the dense canopy of intact $A$. antarctica beds precludes establishment of fast-growing species, such a regime 
shift might not occur through the loss of predators alone (Fig. 1a). Synergistic effects of overfishing and disturbance to foundational species, however, should allow both the establishment of fast-growing seagrasses preferred by megaherbivores now free of predation risk and ultimately lead to a regime shift through positive feedbacks wherein risk-sensitive excavation grazing by dugongs reinforces the early successional state characterized by disturbance-tolerant tropical seagrasses (Fig. 1d). The refuges from herbivory generated by tiger sharks in this system should be most important following a disturbance, where the possibility of a positive grazing feedback is highest (Fig. 1c).

The Western Australian marine heat wave of 2011, during which ocean temperatures rose $2-4^{\circ} \mathrm{C}$ above average for a two month period (Wernberg et al 2013), provided an opportunity to investigate this interaction of predator loss and climactic disturbance in this system. The warming event was driven by strong La Niña conditions which increased the flow of the tropical Leeuwin current southward along the Western coast; this was associated with a catastrophic (>90\%) loss of Amphibolis antarctica (Pearce and Feng 2013, Thomson et al. 2014) and the opening of substrate to early successional tropical seagrasses like Halodule uninervis (Fig. 2), which has become more commonly encountered and more expansive where it occurs in the years since the original seagrass die-off (Chapter III).

I implemented my field experiment following this die-off of A. Antarctica, mimicking changes in dugong foraging behavior consistent with tiger shark extirpation to determine whether a combination of simulated predator loss and climactic disturbance could destabilize remaining A. antarctica beds and generate a phase shift towards a tropical seagrass community. I hypothesized: (1) In Shark Bay's natural, predator rich 
state, grazing in dangerous seagrass bed interiors will be minimal and both A. antarctica and associated tropical seagrass Halodule uninervis will increase in cover (Fig. 1c); (2) In the presence of increased grazing, A. antarctica cover will decline because of incidental removal during excavation grazing (sensu Preen 1995), while H. uninervis will compensate to increase cover (Fig. 1d). I established 30 experimental plots in degraded A. Antarctica beds, separated into 3 grazing treatments (moderate simulated grazing, intense simulated grazing, and control). Divers regularly applied treatments and measured changes in percent cover of A. Antarctica, H. uninervis, and benthic macroalgae. I used mixed effects modeling and model selection to determine the impact of grazing treatments and seagrass bank identity on change in percent cover of seagrass and macroalgae over the experiment's duration.

\section{Methods}

This work was conducted in the eastern gulf of Shark Bay, northeast of Monkey Mia. In April-May 2013, 30 experimental plots, each measuring 3m x 3m, were placed at $2 \mathrm{~m}$ depth in the interiors of two seagrass banks separated by approximately $2 \mathrm{~km}$. Each plot was placed in a degraded $A$. antarctica bed that was characterized by reduced $A$. antarctica cover, prevalence of exposed, dying A. antarctica rhizome tissue, presence of the early successional tropical seagrass Halodule uninervis, and generally low macroalgae cover. Plots were placed in a blocked design on two banks; eighteen plots were placed on a heavily impacted bank (mean initial Amphibolis cover $=17.3 \%$, $s=5.2 \%$ ), and twelve on a moderately impacted bank (mean initial Amphibolis cover $=33.1 \%, s=11.3 \%$ ). Each treatment was equally represented within each block. The mean Halodule cover was similar on both banks (mean $46.4 \% s=21.4 \%$, Welch's t-test: 


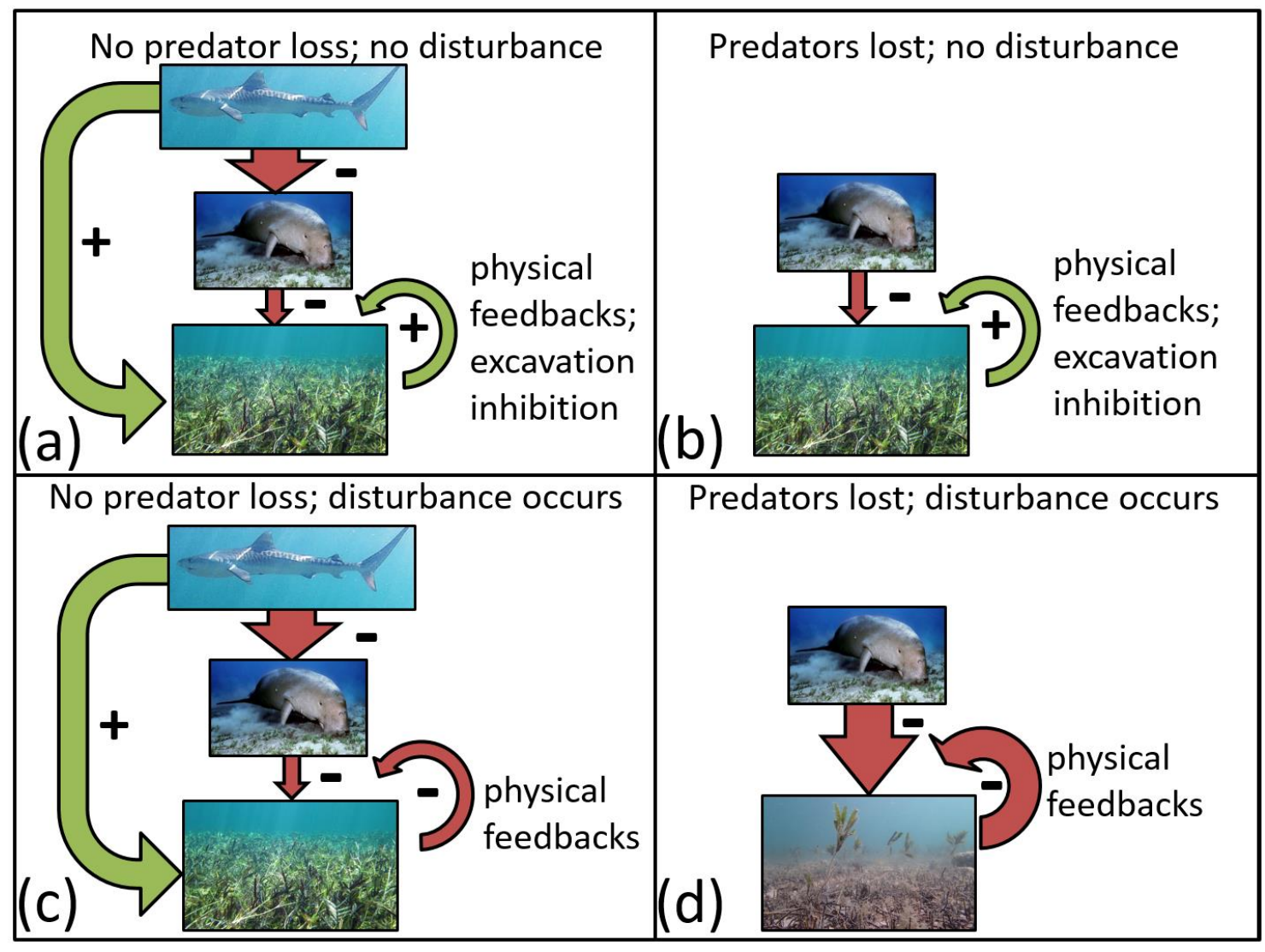

Figure 1. Conceptual diagram of the role of trophic cascades and physical feedbacks in determining the stability and structure of $A$. antarctica beds in Shark Bay. (a) In Shark Bay's normal, undisturbed state, tiger sharks regulate megaherbivores by both consumptive and non-consumptive effects (top red arrow), indirectly facilitating persistence of $A$. Antarctica (left green arrow). Dense seagrass beds generate positive physical feedbacks by trapping sediment and increasing water clarity; these beds also obscure and likely inhibit expansion of the tropical seagrass undercanopy, inhibiting excavation grazing by dugongs and facilitating bed maintenance. (b) With predator losses but without a disturbance, A. Antarctica beds would putatively maintain their ability to generate positive physical feedbacks and inhibit excavation grazing, resulting in a probable loss of resilience but minimal direct impact on A. Antarctica. In (c), a thermal disturbance causes $A$. Antarctica beds to die back, exposing preferred tropical seagrasses, promoting excavation by dugongs, and reversing positive physical feedbacks. It is at this point that behavioral and consumptive control by tiger sharks is anticipated to be critical to minimizing risky excavation grazing in the degraded bed matrix of temperate and tropical seagrasses. In (d), the dieoff of A. Antarctica and loss of apex predators combine to promote destructive excavation grazing, which favors a phase shift towards an ecosystem dominated by disturbance tolerant tropical seagrass at the expense of temperate late successional seagrass species like A. Antarctica. Both (c) and (d) were tested in this experiment. Photos: SBERP, Wikimedia creative commons 
$\left.\mathrm{t}_{24.2}=0.09, \mathrm{p}=0.93\right)$. Macroalgae cover, while generally low (mean $\left.=4.8 \%, s=3.8 \%\right)$ was higher on the heavily impacted bank $(6.8 \%$ vs $2.6 \%$, Mann-Whitney test, $\mathrm{W}=118$, $\mathrm{p}=0.0015)$.
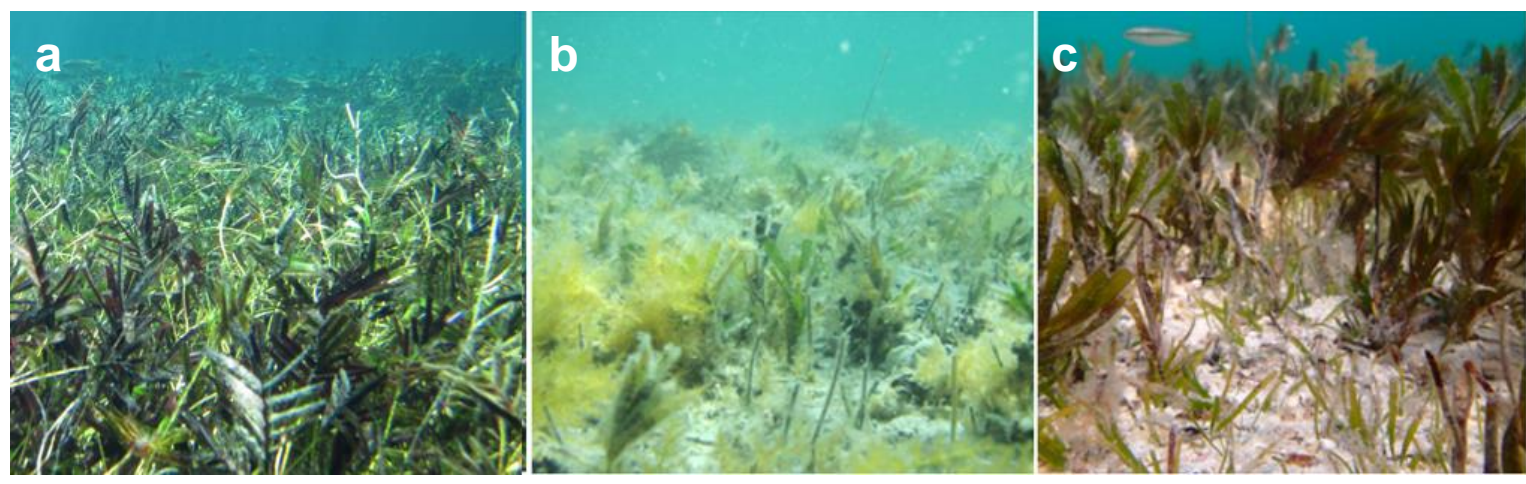

Figure 2. Representative states of the study area's Amphibolis antarctica beds in their pre-decline state (a), approximately 18 months after (b) and 36 months after (c) the 2011 marine heat wave. Notice the tropical early successional seagrass Halodule uninervis (small shoots) growing in between the larger shoots of Amphibolis antarctica in (c). Photos: SBERP

To eliminate biases in location or initial conditions, plots near each other were grouped into trios of similar initial macrophyte cover and location. Plots in each trio were randomly assigned a treatment (control, moderate simulated grazing, and intense simulated grazing) with 10 plots per treatment. Each treatment thus had similar initial cover conditions and were well mixed spatially with plots from other treatments. Plots were marked with a post at each corner. Plots were separated by at least $1 \mathrm{~m}$, but were generally further than $2 \mathrm{~m}$ from each other.

Because experimental manipulation of tiger shark predation risk is not feasible I used published data on risk-sensitive foraging by dugongs in the current study area (Wirsing $2007 \mathrm{a}, \mathrm{b}, \mathrm{c}$ ) to estimate the magnitude of dugong foraging in high-risk habitats 
where the experiments were focused. Dugong foraging effort $\left(\mathrm{sec} * \mathrm{month}^{-1} * \mathrm{plot}^{-1}\right)$ was calculated by:

Eqn. $1 \quad \lambda=\frac{\# \text { foraging dugongs }}{\text { ha of seagrass bank }} \times \frac{1 \text { ha }}{10,000 \mathrm{~m}^{2}} \times \frac{9 \mathrm{~m}^{2}}{1 \text { plot }} \times \frac{2592000 \text { sec }}{1 \text { month }}$

Where $\lambda$ denotes the simulated grazing intensity. Because excavation foraging is a more profitable tactic than cropping (Anderson 1982, 1998), all dugong foraging effort was assumed to be directed towards excavation as long as tropical seagrasses were present. Focal follows of dugongs in the study area allowed us to determine that trails are excavated at the rate of $c a .10 \mathrm{~cm} * \mathrm{sec}^{-1}$. Dugong abundances and activity levels vary seasonally (Wirsing et al. 2007b), so $\lambda$ was calculated separately for each month. Plots were visited every 1-2 months from May 2013 to August 2014 to apply grazing treatments.

Control plots were visited to collect data but did not undergo simulated grazing. This treatment reflects the current risk landscape of Shark Bay where shallow seagrass beds are dangerous habitats for megaherbivores, resulting in general avoidance of shallow beds and low grazing intensity - especially through excavation - on such beds (Wirsing et al. $2007 \mathrm{a}, \mathrm{b}$ ). The moderate simulated grazing treatment mimicked the grazing effort that would be expected if the population size of megaherbivores did not change in response to shark overfishing, but individuals foraging in low-risk but low profitability habitats moved into previously dangerous but productive habitats to forage. These plots received $\lambda / 10$ excavation trails per month, rounded to the nearest integer. Intense simulated grazing treatments were derived by increasing the moderate treatments 
by $50 \%$, to simulate both a behavioral and numerical response of megagrazer populations to shark loss. Though dugong densities have declined by $54 \%$ in the study system since the seagrass die-off, multiple lines of evidence suggest this is driven by emigration, not mass mortality, and that a return of dugong populations to pre-die-off densities is likely to occur before recovery of $A$. antarctica is complete (Chapters III, IV, also see discussion). Nonetheless, the reduction in natural grazing suggests that our simulated grazing did not represent an unrealistic increase in pressure on seagrasses.

Cropping and excavation grazing were simulated manually by divers. Dugong excavation trails were created with hand trowels and had impacts consistent with dugong foraging. Excavation trails did not target Amphibolis antarctica, but if A. antarctica was present in the trail, it was removed to mimic the incidental removal that occurs during excavation foraging (Preen et al.1995). All treatments applied used the excavation tactic if sufficient $H$. uninervis was present (i.e., if a $20 \mathrm{~cm} \times 100 \mathrm{~cm}$ grazing trail frame, consisting of five $20 \mathrm{~cm} \times 20 \mathrm{~cm}$ sub-quadrats, could be placed within the plot so that at least three sub-quadrats contained $H$. uninervis). When sufficient $H$. uninervis was not present, an equal area was grazed by "cropping" A. antarctica, consistent with dugong foraging tactics on this species. In this case, the leaves and leaf sheathes (at the sheathestem interface) were removed from all $A$. antarctica shoots within a grazing trail using a knife. Halodule densities were only rarely low enough to require a switch to simulate cropping.

Simulated feeding trails were straight and measured $15 \mathrm{~cm} \mathrm{~W} \mathrm{x} 100 \mathrm{~cm} \mathrm{~L} \mathrm{x} 4 \mathrm{~cm}$ D. Excavation trails removed all above-ground seagrass and algae biomass inside of the feeding trail. Actual dugong feeding trails are of similar width and depth and remove 
almost all seagrass shoots and rhizomes shallower than 3-5 cm deep (e.g., Preen 1995, De Iongh et al. 1995, Masini et al. 2001, Nakaoka et al. 2002). Seagrass recovery and response to artificial dugong excavation trails is not significantly different from natural feeding trails (De Iongh et al. 1995).

At $0,7,12$, and 16 months into the experiment, cover of $A$. anatarctica, $H$. uninervis, and macroalgae was estimated by divers. A $60 \mathrm{~cm} \times 60 \mathrm{~cm}$ quadrat was placed in one corner of the plot and used to estimate cover, then flipped adjacent to the original quadrat until the cover of the entire plot was estimated, resulting in 25 quadrats per plot. A mean percent cover estimate was generated for each macrophyte group. If a plot was destroyed (catastrophic loss of seagrass cover from sudden widespread seagrass defoliation or storm action), the plot was dropped from further analysis. Statistical analyses

I applied mixed effects modeling and model selection using the NLME package (Pinheiro et al. 2015) in RStudio version 0.98.1091(R Core Team 2014) to determine the importance of bank, grazing treatment, time, and their interactions on cover estimates of A. antarctica, $H$. uninervis, and macroalgae. Four individual a priori models were run for each of the 3 macrophyte groups (Table 1). Percent cover data of A. antarctica and macroalgae were natural log transformed to normalize the data; Halodule cover data were fourth-root transformed. A constant variance $(A$. antarctica) or exponential variance $(H$. uninervis) function was applied to models that displayed heterogeneity. The Akaike Information Criteron (AIC) was used to determine the optimal model (Anderson 2008). When AIC values of competing models were similar (within 2), the similar models were compared using the Likelyhood Ratio Test (LRT) to aid in model selection (Anderson 
2008, Zuur et al. 2009). If the LRT indicated no significant difference between models, the more parsimonious model was retained.

Table 1. Models applied to macrophyte data. Time since start (Time), bank identity (Bank), and grazing treatment (Treat) were fixed effects. Plot ID was included as a random effect to account for temporal autocorrelation of the repeated measures.

\begin{tabular}{clc}
\hline Model & \multicolumn{1}{c}{ Fixed effects } & $\begin{array}{c}\text { Random } \\
\text { effects }\end{array}$ \\
\hline 1 & Time & Plot ID \\
2 & Time + Bank + Time:Bank & Plot ID \\
3 & Time + Bank + Treatment + Time:Treat + Time:Bank & Plot ID \\
4 & Time+ Bank + Treat+ Time:Treat + Time: Bank + & \\
& Time:Bank:Treat & Plot ID \\
\hline
\end{tabular}

\section{Results}

Of the 30 plots established, 29 remained intact for at least 12 months and were retained in analysis; 23 remained intact until experiment's end. Destroyed plots were compromised mostly by small-scale blowout events, and were evenly distributed between treatments ( 2 each in control and intense grazing treatments, 3 in moderate treatments). All plot losses occurred exclusively on the moderately impacted eastern bank.

The application of simulated grazing treatments resulted in significant losses of $A$. antarctica cover but did not strongly affect the covers of tropical seagrasses or macroalgae (Fig. 3). I saw no evidence of a significant general recovery of any macrophyte group, though $A$. antarctica did exhibit increases in cover in the moderately impacted eastern bank in control and moderate grazing treatments. The optimal $A$. antarctica model included treatment, time, bank, and the interactions of bank:time and time:treatment (Table 2). This model was marginally better than the full model 
Table 2. Results of optimal model selection for each macrophyte group. Because the response of interest is change in cover over time, only the interactions of treatment:year and bank:year are included here. Values are only given if that parameter was retained in the optimal model for that macrophyte group. Parameters marked with $\left(^{*}\right)$ are in comparison to the control treatment.

\begin{tabular}{l|ccc|ccc|ccc}
\hline \multirow{2}{*}{ Model parameters } & \multicolumn{3}{c}{ A. antarctica } & \multicolumn{3}{c}{ H. uninervis } & \multicolumn{4}{c}{ Macroalgae } \\
& $\mathrm{t}$ & $\mathrm{df}$ & $\mathrm{p}$ & $\mathrm{t}$ & $\mathrm{df}$ & $\mathrm{p}$ & $\mathrm{t}$ & $\mathrm{df}$ & $\mathrm{p}$ \\
\hline Time & 1.57 & 77 & 0.12 & -6.67 & 80 & $<\mathbf{0 . 0 0 1}$ & -5.37 & 73 & $<\mathbf{0 . 0 0 1}$ \\
Time:Bank & -5.77 & 77 & $<0.001$ & - & - & - & 2.99 & 73 & $\mathbf{0 . 0 0 3 8}$ \\
Time:Simulated Grazing* & -2.81 & 77 & $\mathbf{0 . 0 0 6 3}$ & - & - & - & - & - & - \\
Time: Intense Simulated Grazing* & -3.09 & 77 & $\mathbf{0 . 0 0 2 8}$ & - & - & - & - & - & - \\
\hline
\end{tabular}

Table 3. Initial cover and absolute and relative changes in percent cover of $A$. antarctica and benthic macroalgae. $\mathrm{Ctrl}=$ control treatment, $\mathrm{SG}=$ simulated grazing, $\mathrm{ISG}=\mathrm{Intense}$ simulated grazing, $\mathrm{HI}=$ heavily impacted bank, $\mathrm{MI}=$ moderately impacted bank.

\begin{tabular}{cccccc}
\hline $\begin{array}{c}\text { Factor } \\
\text { (interacting }\end{array}$ & Factor Level & $\begin{array}{c}\text { Initial } \% \\
\text { cover }\end{array}$ & $\begin{array}{c}\text { Absolute } \Delta \% \\
\text { cover }\end{array}$ & SE & $\begin{array}{c}\text { Relative } \Delta \% \\
\text { cover }\end{array}$ \\
\hline \multirow{5}{*}{ J. antarctica } \\
\hline \multirow{5}{*}{ Bank } & Ctrl & $21.2 \%$ & $-4.1 \%$ & $1.3 \%$ & $-19 \%$ \\
& SG & $24.5 \%$ & $-6.1 \%$ & $2.8 \%$ & $-25 \%$ \\
& ISG & $23.9 \%$ & $-12.1 \%$ & $2.1 \%$ & $-51 \%$ \\
& HI & $17.3 \%$ & $-10.1 \%$ & $1.2 \%$ & $-58 \%$ \\
& MI & $33.1 \%$ & $-3.5 \%$ & $2.8 \%$ & $-11 \%$ \\
\hline \multirow{2}{*}{ Bank } & Macroalge & & \\
& $\mathrm{HI}$ & $6.8 \%$ & $-6.6 \%$ & $1.1 \%$ & $-97 \%$ \\
& $\mathrm{MI}$ & $2.6 \%$ & $0.1 \%$ & $0.9 \%$ & $4 \%$ \\
\hline
\end{tabular}

(Likelyhood ratio test $\mathrm{L}=4.83, \mathrm{df}=2, \mathrm{p}=0.089$ ) which also included a 3 way interaction of time:bank:treatment. A. antarctica cover declined over time in grazing treatments but not in control plots on heavily impacted banks; on moderately impacted banks, some recovery of A.antarcica occurred in control and moderately grazed plots (Table 3). $H$. uninervis cover declined similarly across treatments throughout most of the experiment duration $($ mean decline $=-18.2 \%, s=11.5 \%$ ). Moderate grazing plots, however, 


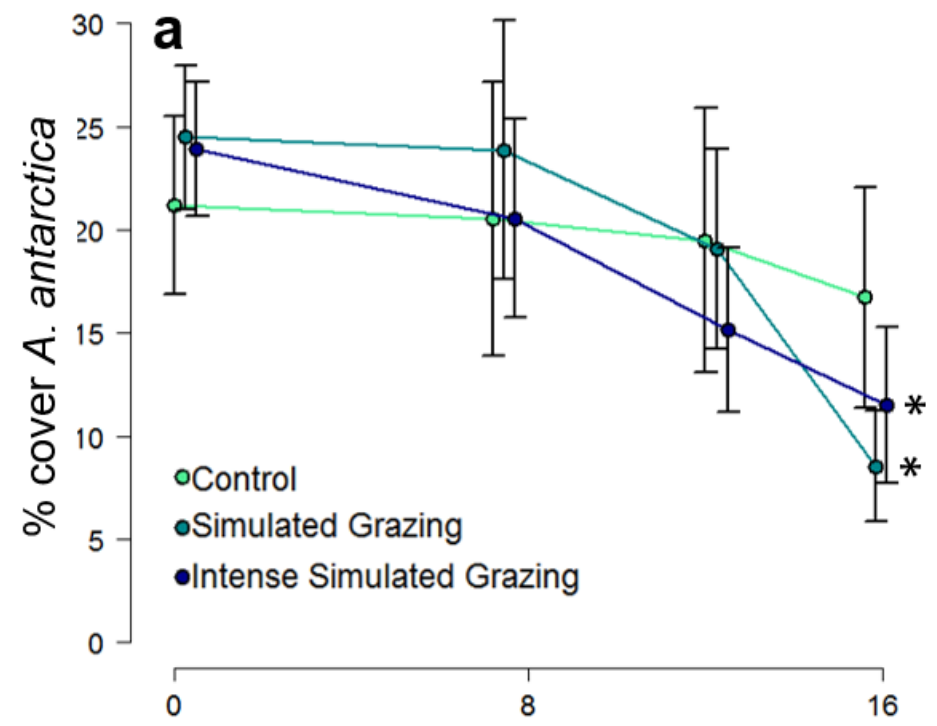

Figure 3. Change in cover of Amphibolis antarctica (a), and Halodule uninervis (b), and benthic macroalgae (c) by grazing treatment. Asterisks indicate significant differences in treatment effects when compared to controls. Points intentionally staggered on the $\mathrm{X}$ axis. Scale of $Y$-axes differ.

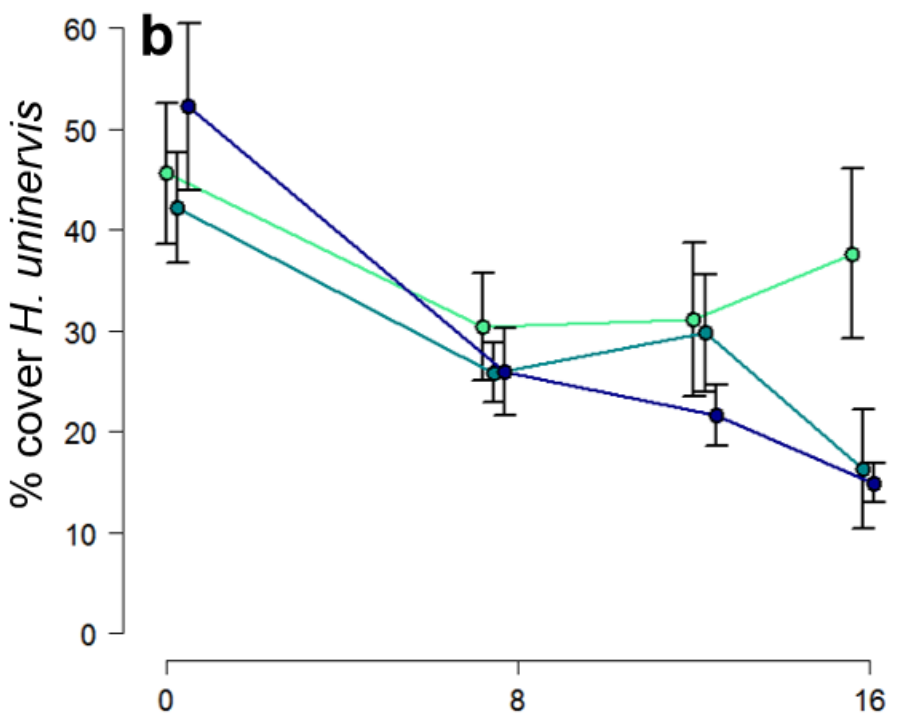

Error bars $=$ SE.

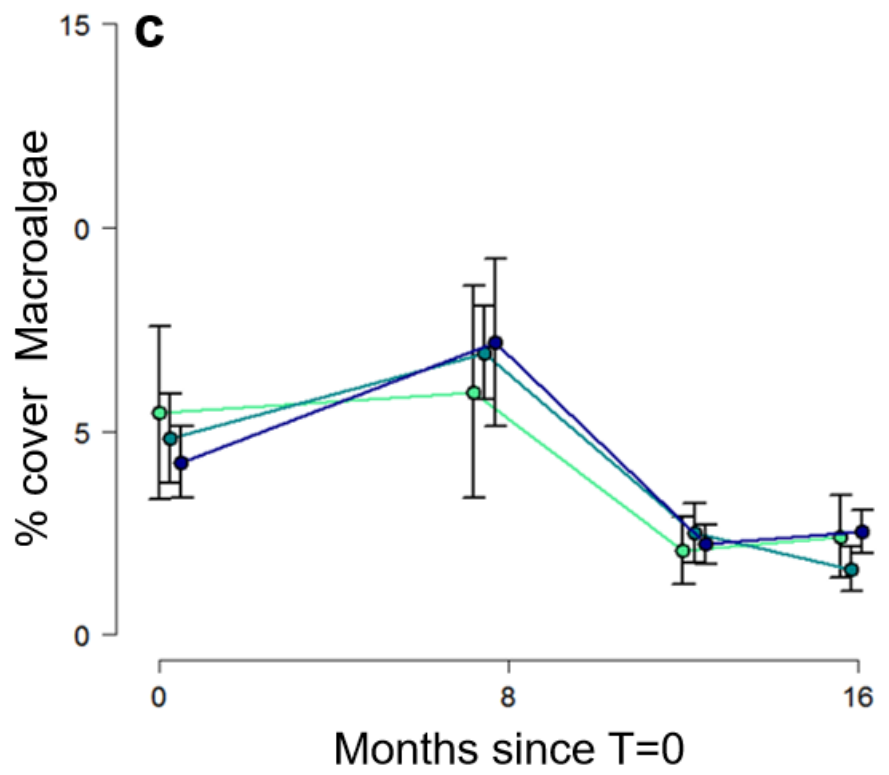


rebounded in cover during the final sampling event (Fig. 3b). Macroalgae cover remained stable on the moderately impacted eastern bank but declined on the heavily impacted western bank, with no differences among grazing treatments (Table 3).

\section{Discussion}

This study indicates that apex predator losses can exacerbate the effects of a climate disturbance by releasing herbivores from predation risk following a climate extreme, when the primary producer community is highly vulnerable to top down control, and that such losses may initiate long-term functional shifts in communities. Specifically, following massive climactic disturbance and seagrass die-back, grazing treatments consistent with a loss of tiger sharks and associated predation risk to dugongs resulted in c.a. 50\% losses of remaining Amphibolis antarctica cover. Conversely, other macrophytes such as the early successional seagrass Halodule uninervis and benthic macroalgae were insensitive to grazing treatments, instead declining generally with time. This suggests that apex predator loss exacerbates the effects of a climactic disturbance in this system, and would likely lead to a phase shift to an ecosystem devoid of many of the functions characteristic of intact meadows of late-successional seagrasses.

A. antarctica cover remained fairly stable in control plots, but declined in cover by c.a. $50 \%$ in grazing treatments. As A. antarctica is a late successional seagrass with generally long return times following large losses (see Chapter III and references therein), such a decline after only 16 months of simulated predator loss implies that elimination of the "seascape of fear" generated by tiger sharks in Shark Bay would lead to a phase shift away from an $A$. antarctica dominated ecosystem. Interestingly, the final A. antarctica model was only a marginal improvement over than the full model 
$(\mathrm{p}=0.089)$, which included a three way interaction of bank, treatment, and time. Though not significant, this hints that the two banks, which differed in their initial cover of $A$. antarctica, may exhibit somewhat divergent responses to grazing treatments. If true, this suggests that intensity of initial disturbance may mediate impacts of predator losses at more fine scales than a simple "disturbed / undisturbed" dichotomy presented here. Further work, in which a full design crossing predator loss and intensity of disturbance, would be valuable in determining the validity of this relationship.

Responses of macroalgae and Halodule uninervis in this experiment indicate that other structurally complex macrophytes are unlikely to fill functional roles (habitat creation, sediment re-suspension) left vacant by $A$. antarctica. Declines in already very low algae cover (Fig. 3c) indicate that macroalgae do not play a dominant role in the post-disturbance macrophyte community. H. uninervis also declined with time, though neither macrophyte group was impacted by grazing treatment (Fig. 3b).

The H. uninervis results are more difficult to interpret than those of $A$. antarctica, as insensitivity of this seagrass to grazing treatment was driven by general declines in $H$. uninervis in all treatments. At first glance, a general decline in $H$. uninervis cover conflicts with the life history strategy of $H$. uninervis as an early successional seagrass (Larkum et al. 2006) and with results from sampling at broader geographic scales, which indicate $H$. uninervis is becoming more common throughout the study system (Chapter III). This discrepancy may be caused by patch movement (Walker et al. 2006 and references therein) or the ephemeral nature of this seagrass; for example, Burkholder et al. (2013b) noticed high variability in $H$. uninervis shoot densities in interior microhabitats near this experiment over a 600 day enclosure experiment. Plot placement 
was dictated by relatively high initial $H$. uninervis cover, so it is more likely that patch movement would result emigration of $H$. uninervis rather than immigration.

Alternatively, application of grazing to treatment plots which $H$. uninervis cover in treatment plots, may have resulted in spatial shifts in mesograzers like the herbivorous teleost Pelates octolineatus to the relatively "rich" control plots. Indeed, P. octolineatus dominates the seagrass associated teleost community even after the die-off (Heithaus 2004, Nowicki et al. in preparation) and H. uninervis is readily consumed over $A$. antarctica by mesograzers (Burkholder et al. 2012). Though the mechanism of declines of $H$. uninervis in control plots remains unknown, this does not alter the conclusions presented here. In other systems, heavy grazing pressure by dugongs can result in near total bed destruction, followed by rapid recolonization by tropical seagrass species (Preen 1995, Nakaoka and Aioi 1999). In response, dugongs and green turtles abandon seagrass patches as they become depleted in seagrass cover, only to revisit these sites as they recover to take advantage of higher nutrient concentrations in re-growing tissues (Bjorndal 1980, Preen 1995, Aragones et al. 2006, de Iongh et al. 2007). In this experiment, there were several plots in which $H$. uninervis cover increased substantially after being almost completely absent a few months earlier. This demonstrates that even in the presence of sustained grazing pressure or large fluctuations over relatively short time scales (when compared to recovery times of $A$. antarctica), early-successional seagrass are likely to persist and continue to attract destructive excavation grazing to degraded beds of $A$. antarctica.

Declines in dugong density since the seagrass die-off (Chapter IV) are also unlikely to alter the conclusions presented here. This is because (1) there was no change 
in seasonal patterns of risk sensitive dugong habitat use following the decline, indicating predation risk is still a viable mechanism to enhance post-disturbance stability (Chapter IV); (2) several lines of evidence suggest that dugong declines are driven by emigration from the study system to alternate foraging areas, not mass mortality (Chapter IV); (3) dugongs are known to undertake large scale movements between foraging areas in response to large-scale seagrass loss, with re-immigration occurring within relatively short time scales as tropical seagrasses recover (Preen and Marsh 1995, Marsh and Lawler 2001, Holley 2006, Hodgson 2007); and (4) H. uninervis, preferred by dugongs (Preen 1995), has recovered beyond its pre-die-off extent and is continuing to expand (Chapter III). Furthermore, reports from a wildlife cruise operator in the study area indicate that since 2014, dugongs are becoming more common (K. Justice, pers. communication), suggesting that dugong densities are beginning to recover.

Others have suggested that predators can mediate the ecological impacts of climate change (e.g., Ripple et al. 2014, Estes et al. 2011, Sala 2006). For example, gray wolves (Canis lupus) in Yellowstone National Park, USA, reduce resource bottlenecks to carrion scavengers associated with shifts to shorter winters and earlier snow thaw by increasing carrion availability in late winter. This dampens the effects of climate change on carrion scavengers (Wilmers and Gets 2005). Similarly, a combination of climate change induced range shifts of the long-spined sea urchin (Centrostephanus rodgersii) and overfishing of predatory spiny lobster (Jasus edwardsii) in Tasmanian kelp forests increased the risk of phase shifts to urchin barrens (Ling et al. 2009). However, while there is growing appreciation for the capability of predators to influence ecosystem responses to climate change, the role of predation risk in this regard is still relatively 
poorly understood. Here I show that predation risk can stabilize cover of a dominant ecosystem engineer, potentially increasing the resilience of the ecosystem. Because many seagrasses, particularly late successional seagrasses, are highly vulnerable to disturbance and are characterized by generally long recovery times, maintenance of the risk landscape of Shark Bay is likely critical to facilitating a return to an A. antarctica dominated system and the functions such dominance provides. More generally, this work suggests that predators can mediate the effects of climate extremes not only through consumptive effects, but also through non-consumptive effects and the BMTCs such effects generate. While predator loss and climate change are both global threats to the functional integrity and resilience of ecosystems, the temporal and spatial scales at which these two stressors can be functionally addressed differ greatly. Indeed, management at local and regional levels for ecological resilience may be key to preventing catastrophic phase shifts while long-term action is taken on climate change (e.g., DeYoung et al. 2008). Therefore, restoration of top predators and the ecological resilience they can impart may be a valid (if ambitious) short-term strategy to reduce the likelihood of destructive regime shifts caused by climate change as we attempt to slow and eventually rein in our effects on Earth's climate. However, future work is needed to determine the ecological conditions under which predator restoration is most likely to yield measurable increases in resilience to climate extremes. This strategy of climate resilience through predator restoration may be most effective in systems with highly iteroparous herbivores (such as Shark Bay), which are likely to invest highly in anti-predator behavior (Clark 1994) and thus are likely to propagate BMTCs. Indeed, such a strategy for local resilience to climate extremes may become increasingly important as megafauna restoration efforts 
such as those for the herbivorous green turtle (Chelonia mydas) continue to succeed (Heithaus et al. 2014). Without a concomitant effort to also restore the predators of these herbivores, the resilience of plant communities to future climate disturbances may be reduced.

With continued declines of top predators in terrestrial, freshwater, and marine ecosystems (e.g., Estes et al. 2011, Ripple et al. 2014), successful restorations of previously rare megaherbivores (e.g., Heithaus et al. 2014), and increasing impacts to foundation species through extreme climactic events (e.g., Easterling et al. 2000), there is an urgent need to understand how ecosystems will respond to the combination of top predator loss and climate change (Baum and Worm 2009). While previous work indicates that top predators may be important mediators of ecosystem responses to climate change, the potential for top predators to enhance resilience to climate change remains poorly studied and understood. In particular, the capability of non-consumptive predator effects to mediate the impacts of climate change to ecosystems has received little attention (Baum and Worm 2009). Here I show that simulated shifts in risksensitive behavior by dugongs in a manner consistent with tiger shark loss would exacerbate the impacts of an extreme climate event in Shark Bay. To my knowledge this is among the first studies to examine whether predation risk may influence ecosystem responses to climactic extremes. Though it is yet unclear how widely predation risk may alter resilience of ecosystems to climactic extremes, the global nature of apex predator loss and climate change suggest that co-occurrence of these two stressors is widespread. Identifying when predator effects are most likely to yield increased resilience to climate extremes will be critical to determining the potential effectiveness of predator restoration 
as a technique to increase ecological resilience and maintain ecological function in a changing world.

\section{Acknowledgements}

I would like to acknowledge the critical assistance of field crews including J. Olson, A.

Macy, R. Sarabia, J. Johnson, N. Norton, A. Morgan, K. Gastrich, M. Jew, T. Code, H. Neutzel, and C. Morgan. I would also like to thank the people of Monkey Mia Dolphin Resort and Shark Bay for considerable logistical support. Funding was provided by an NSF Rapid Response grant awarded to MRH, an NSF Graduate Research Fellowship awarded to RJN, a PADI foundation award to RJN, and donations from the public.

Comments from R. Sarabia improved the manuscript.

\section{Literature Cited}

Anderson, D.R. (2008). Model Based Inference in the Life Sciences: A Primer on Evidence. Springer New York, New York, NY.

Anderson, P. (1982). Studies of Dugongs at Shark Bay,Western Australia. II.* Surface and Subsurface Observations. Wildlife Research, 9, 85.

Anderson, P.K. (1998). Shark Bay dugongs (Dugong dugon) in summer. II: Foragers in a Halodule-dominated community. Mammalia, 62, 409-426.

Aragones, L.V., Lawler, I.R., Foley, W.J. \& Marsh, H. (2006). Dugong grazing and turtle cropping: grazing optimization in tropical seagrass systems? Oecologia, 149, 635-647.

Atwood, T.B., Connolly, R.M., Ritchie, E.G., Lovelock, C.E., Heithaus, M.R., Hays, G.C., et al. (2015). Predators help protect carbon stocks in blue carbon ecosystems. Nature Climate Change, 5, 1038-1045.

Baum, J.K. \& Worm, B. (2009). Cascading top-down effects of changing oceanic predator abundances. Journal of Animal Ecology, 78, 699-714. 
Bjorndal, K.A. (1980). Nutrition and grazing behavior of the green turtle Chelonia mydas. Marine Biology, 56, 147-154.

Borowitzka, M., Lavery, P. \& van Keulen, M. (2006). Chapter 19: Epiphytes of Seagrasses. In:Seagrasses: Biology, Ecology, and Conservation (eds. Larkum, A., Orth, R. \& Duarte, C.). Springer, Dordrecht, The Netherlands, pp. 441-461.

Britten, G.L., Dowd, M., Minto, C., Ferretti, F., Boero, F. \& Lotze, H.K. (2014). Predator decline leads to decreased stability in a coastal fish community. Ecology letters, $17,1518-1525$.

Burkholder, D.A., Heithaus, M.R. \& Fourqurean, J.W. (2012). Feeding preferences of herbivores in a relatively pristine subtropical seagrass ecosystem. Marine and Freshwater Research, 63, 1051-1058.

Burkholder, D.A., Fourqurean, J.W. \& Heithaus, M.R. (2013a). Spatial pattern in seagrass stoichiometry indicates both $\mathrm{N}$-limited and P-limited regions of an iconic P-limited subtropical bay. Marine Ecology Progress Series, 472, 101-115.

Burkholder, D.A., Heithaus, M.R., Fourqurean, J.W., Wirsing, A. \& Dill, L.M. (2013b). Patterns of top-down control in a seagrass ecosystem: could a roving apex predator induce a behaviour-mediated trophic cascade? Journal of Animal Ecology, 82, 1192-1202.

Cai W, Borlace S, Lengaigne M, Van Rensch P, Collins M, Vecchi G, Timmermann A, Santoso A, McPhaden MJ, Wu L, England MH, Wang G, Guilyardi E, Jin, F. (2014) Increasing frequency of extreme El Niño events due to greenhouse warming. Nature Climate Change 4:111-116

Cai W, Wang G, Santoso A, McPhaden MJ, Wu L, Jin F-F, Timmermann A, Collins M, Vecchi G, Lengaigne M, England MH, Dommenget D, Takahashi K, Guilyardi E (2015) Increased frequency of extreme La Niña events under greenhouse warming. Nature Clim Change 5:132-137

Clark, C.W. (1994). Antipredator behavior and the asset-protection principle. Behavioral Ecology, 5, 159-170.

Crain, C.M., Kroeker, K. \& Halpern, B.S. (2008). Interactive and cumulative effects of multiple human stressors in marine systems. Ecology letters, 11, 1304-1315.

Daskalov, G.M., Grishin, A.N., Rodionov, S. \& Mihneva, V. (2007). Trophic cascades triggered by overfishing reveal possible mechanisms of ecosystem regime shifts. Proceedings of the National Academy of Sciences, 104, 10518-10523. 
De Iongh, H.H., Kiswara, W., Kustiawan, W. \& Loth, P.E. (2007). A review of research on the interactions between dugongs (Dugong dugon Müller 1776) and intertidal seagrass beds in Indonesia. Hydrobiologia, 591, 73-83.

De Iongh, H.H., Wenno, B.J. \& Meelis, E. (1995). Seagrass distribution and seasonal biomass changes in relation to dugong grazing in the Moluccas, East Indonesia. Aquatic Botany, 50, 1-19.

deYoung, B., Barange, M., Beaugrand, G., Harris, R., Perry, R.I., Scheffer, M., et al. (2008). Regime shifts in marine ecosystems: detection, prediction and management. Trends in ecology \& evolution, 23, 402.

Easterling, D.R., Meehl, G.A., Parmesan, C., Changnon, S.A., Karl, T.R. \& Mearns, L.O. (2000). Climate extremes: observations, modeling, and impacts. Science, 289, 2068-2074.

Estes, J.A., Terborgh, J., Brashares, J.S., Power, M.E., Berger, J., Bond, W.J., et al. (2011). Trophic downgrading of planet Earth. Science, 333, 301-306.

Estes, J.A., Heithaus, M., McCauley, D.J., Rasher, D.B. \& Worm, B. (2016). Megafaunal Impacts on Structure and Function of Ocean Ecosystems. Annual Review of Environment and Resources, 41.

Ferretti, F., Worm, B., Britten, G.L., Heithaus, M.R. \& Lotze, H.K. (2010). Patterns and ecosystem consequences of shark declines in the ocean. Ecology letters, 13, 1055-1071.

Harley, C.D. (2011). Climate change, keystone predation, and biodiversity loss. Science, $334,1124-1127$.

Harley, C.D. \& Paine, R.T. (2009). Contingencies and compounded rare perturbations dictate sudden distributional shifts during periods of gradual climate change. Proceedings of the National Academy of Sciences, 106, 11172-11176.

Harley, C.D., Randall Hughes, A., Hultgren, K.M., Miner, B.G., Sorte, C.J., Thornber, C.S., et al. (2006). The impacts of climate change in coastal marine systems. Ecology letters, 9, 228-241.

Heithaus, M.R. (2004). Fish communities of subtropical seagrass meadows and associated habitats in Shark Bay, Western Australia. Bulletin of Marine Science, 75, 79-99.

Heithaus, M.R., Alcoverro, T., Arthur, R., Burkholder, D.A., Coates, K.A., Christianen, M.J., et al. (2014). Seagrasses in the age of sea turtle conservation and shark overfishing. Frontiers in Marine Science, 1, 28. 
Heithaus, M.R., Frid, A., Wirsing, A.J. \& Worm, B. (2008). Predicting ecological consequences of marine top predator declines. Trends in Ecology \& Evolution, 23, 202-210.

Heithaus, M.R., Wirsing, A.J. \& Dill, L.M. (2012). The ecological importance of intact top-predator populations: a synthesis of 15 years of research in a seagrass ecosystem. Marine and Freshwater Research, 63, 1039-1050.

Hodgson, A. (2007). The distribution, abundance and conservation of dugongs and other marine megafauna in Shark Bay Marine Park, Ningaloo Reef Marine Park and Exmouth Gulf. Department of Environment and Conservation.

Holley, D. (2006). Movement patterns and habitat usage of Shark Bay dugongs. Edith Cowan University.

Jeffries, M.J. \& Lawton, J.H. (1984). Enemy free space and the structure of ecological communities. Biological Journal of the Linnean Society, 23, 269-286.

Jones, C.G., Lawton, J.H. \& Shachak, M. (1994). Organisms as ecosystem engineers. In: Ecosystem management. Springer, pp. 130-147.

Larkum, A., Orth, R. \& Duarte, C. (Eds.). (2006). Seagrasses: Biology, Ecology, and Conservation. Springer Netherlands, Dordrecht.

Ling, S.D., Johnson, C.R., Frusher, S.D. \& Ridgway, K.R. (2009). Overfishing reduces resilience of kelp beds to climate-driven catastrophic phase shift. Proceedings of the National Academy of Sciences, 106, 22341-22345.

Marsh, H. \& Lawler, I. (2001). Dugong distribution and abundance in the Southern Great Barrier Reef Marine Park and Hervey Bay: results of an aerial survey in OctoberDecember 1999. GBRMPA Research Publication, 70.

Masini, R.J., Anderson, P.K. \& McComb, A.J. (2001). A Halodule-dominated community in a subtropical embayment: physical environment, productivity, biomass, and impact of dugong grazing. Aquatic Botany, 71, 179-197.

Mineur, F., Arenas, F., Assis, J., Davies, A.J., Engelen, A.H., Fernandes, F., et al. (2015). European seaweeds under pressure: Consequences for communities and ecosystem functioning. Journal of Sea Research, 98, 91-108.

Nakaoka, M. \& Aioi, K. (1999). Growth of seagrass Halophila ovalis at dugong trails compared to existing within-patch variation in a Thailand intertidal flat. Marine Ecology Progress Series, 184, 97-103. 
Nowicki, R. \& Heithaus, M. (In preparation). Seagrass functional redundancy and differential environmental tolerance mediates response of teleost community to catastrophic seagrass loss.

Pachauri, R.K., Allen, M.R., Barros, V.R., Broome, J., Cramer, W., Christ, R., et al. (2014). Climate Change 2014: Synthesis Report. Contribution of Working Groups I, II and III to the Fifth Assessment Report of the Intergovernmental Panel on Climate Change.

Pearce, A.F. \& Feng, M. (2013). The rise and fall of the "marine heat wave" off Western Australia during the summer of 2010/2011. Journal of Marine Systems, 111, 139156.

Pinheiro, J., Bates, D., DebRoy, S., Sarkar, D. \& R Core Team. (2015). nlme: Linear and Nonlinear Mixed Effects Models. Available at: http://CRAN.Rproject.org/package $=$ nlme.

Preen, A. (1995). Impacts of dugong foraging on seagrass habitats: observational and experimental evidence for cultivation grazing. Marine Ecology Progress Series, 124, 201-213.

Preen, A. \& Marsh, H. (1995). Response of dugongs to large-scale loss of seagrass from Hervey Bay, Queensland, Australia. Wildlife Research, 22, 507-519.

Preisser, E.L., Bolnick, D.I. \& Benard, M.F. (2005). Scared to death? The effects of intimidation and consumption in predator-prey interactions. Ecology, 86, 501509.

R Core Team. (2015). R: A language and environment for statistical computing. R Foundation for Statistical Computing, Vienna, Austria.

Richardson, A.J. \& Poloczanska, E.S. (2008). Under-resourced, under threat. Science, $320,1294$.

Ripple, W.J., Estes, J.A., Beschta, R.L., Wilmers, C.C., Ritchie, E.G., Hebblewhite, M., et al. (2014). Status and ecological effects of the world's largest carnivores. Science, 343, 1241484.

Sala, E. (2006). Top predators provide insurance against climate change. Trends in ecology \& evolution, 21, 479-480.

Schindler, D.W., Frost, T.M., Mills, K.H., Chang, P.S.S., Davies, I.J., Findlay, L., et al. (1990). Comparisons between experimentally-and atmospherically-acidified lakes during stress and recovery. Proceedings of the Royal Society of Edinburgh.

Section B. Biological Sciences, 97, 193-226. 
Schmitz, O.J. (2008). Effects of predator hunting mode on grassland ecosystem function. Science, 319, 952-954.

Taylor, S.A., Larson, E.L. \& Harrison, R.G. (2015). Hybrid zones: windows on climate change. Trends in ecology \& evolution, 30, 398-406.

Thomson, J.A., Burkholder, D.A., Heithaus, M.R., Fourqurean, J.W., Fraser, M.W., Statton, J., et al. (2015). Extreme temperatures, foundation species, and abrupt ecosystem change: an example from an iconic seagrass ecosystem. Global change biology, 21, 1463-1474.

Walker, D.I., Kendrick, G.A. \& McComb, A.J. (1988). The distribution of seagrass species in Shark Bay, Western Australia, with notes on their ecology. Aquatic Botany, 30, 305-317.

Walker, D., Kendrick, G. \& McComb, A. (2006). Chapter 23: Decline and Recovery of Seagrass Ecosystems - The Dynamics of Change. In: Seagrasses: Biology, Ecology, and Conservation (eds. Larkum, A., Orth, R. \& Duarte, C.). Springer, Dordrecht, The Netherlands, pp. 553-565.

Wernberg, T., Smale, D.A., Tuya, F., Thomsen, M.S., Langlois, T.J., De Bettignies, T., et al. (2013). An extreme climatic event alters marine ecosystem structure in a global biodiversity hotspot. Nature Climate Change, 3, 78-82.

Werner, E.E. \& Peacor, S.D. (2003). A review of trait-mediated indirect interactions in ecological communities. Ecology, 84, 1083-1100.

Wirsing, A.J., Heithaus, M.R. \& Dill, L.M. (2007a). Can you dig it? Use of excavation, a risky foraging tactic, by dugongs is sensitive to predation danger. Animal Behaviour, 74, 1085-1091.

Wirsing, A.J., Heithaus, M.R. \& Dill, L.M. (2007b). Fear factor: do dugongs (Dugong dugon) trade food for safety from tiger sharks (Galeocerdo cuvier)? Oecologia, 153, 1031-1040.

Wirsing, A.J., Heithaus, M.R. \& Dill, L.M. (2007c). Living on the edge: dugongs prefer to forage in microhabitats that allow escape from rather than avoidance of predators. Animal Behaviour, 74, 93-101.

Zarnetske, P.L., Skelly, D.K. \& Urban, M.C. (2012). Biotic multipliers of climate change. Science, 336, 1516-1518. 
Zuur, A.F., Ieno, E.N., Walker, N., Saveliev, A.A. \& Smith, G.M. (2009). Mixed effects models and extensions in ecology with R. Statistics for Biology and Health. Springer New York, New York, NY. 


\section{CHAPTER VI}

SUMMARY AND FUTURE DIRECTIONS 
In this dissertation I compiled an extensive review of top-down control in seagrass ecosystems, investigated the post-disturbance dynamics of one of the world's most iconic seagrass ecosystems following a widespread climactic disturbance, quantified how such a widespread loss of seagrass impacts the abundance and risk-sensitive habitat use of a variety of consumers within Shark Bay, and conducted an experiment to determine the role of simulated apex predator loss on stability of Shark Bay's disturbed seagrass community. As such, a central goal of this work was to determine whether (and if so, how) this climactic extreme event impacts the flora, fauna, ecological processes, and resilience of one of the world's most iconic seagrass ecosystems. An additional goal of this work was to provide data that may refine predictions of how climate change disturbances and anthropogenic alterations to top-down control will influence ecosystems in the future.

Ecosystems are notoriously complex, making reliable prediction difficult. However, achieving predictive power in the field of ecology is the most promising way in which we can solve ecological crises. Throughout this dissertation I have used the natural experiment presented in the form of a marine heat wave and large scale seagrass loss to test ecological theory and add to existing predictive frameworks. Chapter II provided a current review of top-down control in seagrass ecosystems, with particular focus on the Australian continent where this work was conducted. This chapter concluded with an extensive list of questions about how top-down control may influence seagrass responses to climate change. Chapter III identified patterns in the postdisturbance dynamics of submerged aquatic vegetation following an extreme climactic event and subsequent massive seagrass loss. The results indicate that, as in many (but not 
all) other systems, the late successional seagrass Amphibolis antarctica is not recovering from disturbance quickly, and is highly likely to be vulnerable to future perturbations. Meanwhile, an early successional and tropical seagrass, Halodule uninervis, is becoming more common and may signify a community shift to a tropically dominated state.

Chapter III concluded by discussing potential drivers of recovery (or a phase shift), which will depend in part on ecological properties of the ecosystem. Chapter IV focused on whether this massive resource loss (of seagrass and the teleosts associated with it) impacted a variety of seagrass-associated megafauna. Understanding how consumers respond to resource loss is critical to predicting how top down control (including herbivory, predation, risk effects) will shape the post-disturbance dynamics of primary producer communities. In this study, several consumers (Piedcormorants, green turtles, dugongs, and sea snakes) suffered significant density declines in response to the seagrass die-off, though the mechanisms responsible for species-specific declines likely differ (Chapter IV). Importantly, abundances of tiger sharks (Galeocerdo cuvier), the apex predator in this system, were unaffected by seagrass loss. As a result, the "seascape of fear" remained intact in the system, allowing for a test of the impacts of resource loss on anti-predator behavior by multiple species at an unusually large landscape scale. Therein I found that multiple species (particularly piscivorous Piedcormorants and Indo-Pacific bottlenose dolphins) began to over-use dangerous seagrass bank interiors where remaining resources were concentrated. These results provide empirical support of theory that suggests that resource losses induced by climactic disturbance can alter the ecological role of predators by shifting the relative importance of consumptive and nonconsumptive predator effects. The goal of Chapter V was to determine whether 
predation risk can enhance ecosystem resilience to climactic disturbance. I found that under grazing regimes consistent with a loss of predation risk, heavily impacted beds of Amphibolis antarctica declined, suggesting that risk of predation can be an important mechanism though which resilience is maintained. To my knowledge, previous work has not identified predation risk as an important component of ecological resilience to climate change.

A central goal in the field of climate change ecology is understanding when and where climate extremes are likely to lead to phase shifts, and what will drive resilience and resistance to such extremes. While the answer to this question is still unresolved, theoretical and empirical data are growing. It can be expected that an ecosystem's response to a climactic extreme event will depend not only on the properties of the disturbance itself (i.e., nature, intensity, duration, timing), but also on the biotic and biophysical properties of the ecosystem (such as plant and animal life histories, trophic structure, biophysical feedbacks, etc., Zarnetske et al. 2012, Unsworth et al. 2015, Chapter III, Fig 1). Resolving under what conditions various ecosystem properties (and interactions) are important to mediating ecosystem responses to climactic disturbances will be critical to creating a broad predictive framework for how ecosystems respond to climactic extremes.

This dissertation adds to a growing framework for understanding and predicting ecological responses to climate extremes, but also generates new questions. For example, why do some, but not all, consumers alter anti-predator behavior in the face of resource loss? How commonly do non-consumptive predator effects generate resilience to climactic extremes? How will mismatched conservation efforts of large herbivores and 
their predators impact resilience to climate change? There is much work yet to be done before a predictive framework encompassing these questions is complete- but continued progress towards this goal is critical to managing Earth's ecosystems in the Anthropocene.

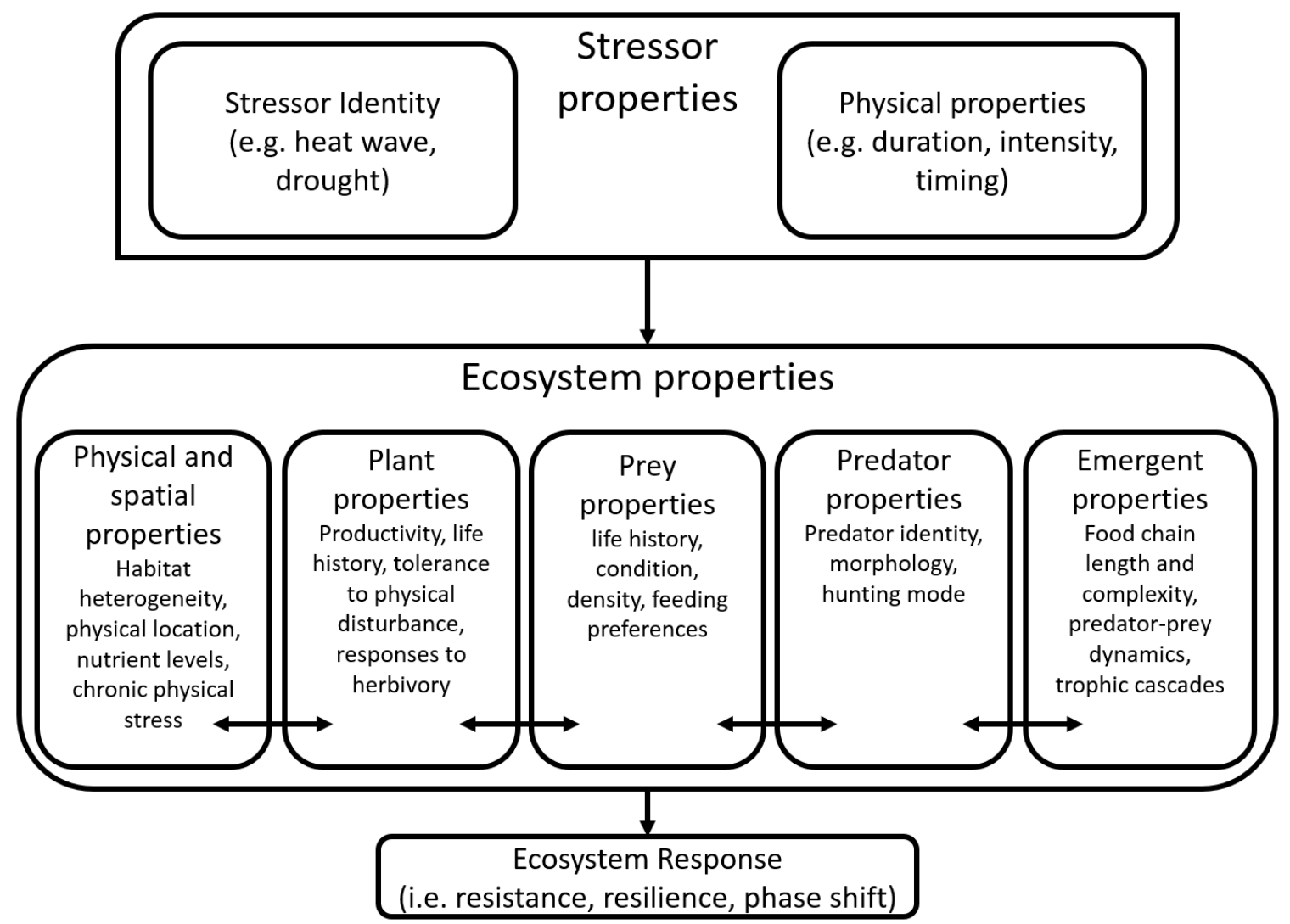

Figure 1. Conceptual model illustrating response of an ecosystem to a climactic extreme as dependent on both properties of the stressor (e.g., intensity, duration, timing, identity) and properties of the ecosystem (which are largely biotic in nature). In both cases, properties may interact to influence the effects of stressors (interactions not shown). 


\section{Literature Cited}

Unsworth RKF, Collier CJ, Waycott M, Mckenzie LJ, Cullen-Unsworth LC (2015) A framework for the resilience of seagrass ecosystems. Marine Pollution Bulletin $100: 34-46$

Zarnetske, P.L., Skelly, D.K. \& Urban, M.C. (2012). Biotic multipliers of climate change. Science, 336, 1516-1518. 
VITA

ROBERT JAMES NOWICKI

2010

\author{
B.S., Marine Biology \\ University of North Carolina, Wilmington \\ Wilmington, North Carolina
}

PUBLICATIONS AND PRESENTATIONS

Nowicki, R*., Heithaus, M., Fourqurean, J. In press. The role of consumers in structuring seagrass ecosystems: direct and indirect mechanisms. Biology of Seagrasses, Second edition. Springer.

Stroud, J.T., Bush, M., Ladd, M., Lemoine, N., Nowicki, R*., Shantz, A., Sweatman, A. 2015. Is a community still a community? Reviewing definitions of key terms in community ecology. Ecology and Evolution 5 (21).

Nowicki, R.*, Thomson, J., Fourqurean, J., Heithaus, M. “Can tiger sharks help coastal ecosystems recover from climactic disturbances?" 12 August 2016. 101 $1^{\text {st }}$ annual meeting of the Ecological Society of America (ESA). Ft. Lauderdale, Florida.

Nowicki, R.*, Burkholder, D., Vaudo, J., Gastrich, K., Thomson, J., Bessey, C., Cameron, K., Dumphy-Daly, M., Heithaus, M. "Response of an apex predator, the tiger shark (Galeocerdo cuvier), to widespread seagrass decline.” 7 Jul 2016. $33^{\text {rd }}$ annual meeting of the American Elasmobranch Society. New Orleans, La.

Nowicki, R.*, Heithaus, M. "Climate change, predator loss, and the resilience of an iconic seagrass ecosystem.” 29 April 2016. Smithsonian Marine Station Scientific Seminar Series. Ft. Pierce, Florida.

Nowicki, R.*, Thomson, J., Fourqurean, J., Heithaus, M. "Can tiger sharks help coastal ecosystems recover from climactic disturbances?" 28 March 2016. Florida International University $6^{\text {th }}$ annual Scholarly Forum. Miami, Florida.

Nowicki, R.*, Heithaus, M. "Resistance, resilience, and the response of a teleost community to catastrophic seagrass loss." 25 March 2016. Florida International University Science and Suds forum. North Miami, Florida.

Nowicki, R.*, Heithaus, M. "Resistance, resilience, and the response of a teleost community to catastrophic seagrass loss." 17 March 2016. $45^{\text {th }}$ Benthic Ecology Meeting, Portland, Maine.

Nowicki, R.*, Heithaus, M. "Nothing in ecology makes sense”. 6 February 2016. 
Florida International University $18^{\text {th }}$ annual Research Bio-symposium. North Miami, Florida.

Nowicki, R.*, Thomson, J., Fourqurean, J., and Heithaus, M. "Effects of predation risk from tiger sharks (Galeocerdo cuvier) on resilience of an iconic seagrass ecosystem following a widespread climate driven disturbance". 19 July 2015. $31^{\text {st }}$ American Elasmobranch meeting, Reno, Nevada.

Nowicki, R.*, Thomson, J., Fourqurean, J., and Heithaus, M. "Effects of predation risk from tiger sharks (Galeocerdo cuvier) on resilience of an iconic seagrass ecosystem following a widespread climate driven disturbance”. 31 January 2015. Florida International University $17^{\text {th }}$ annual Research Biosymposium. North Miami, Florida.

Nowicki, R.* "Impacts of a catastrophic seagrass decline on the marine fauna of Shark Bay”. 16 July 2014. Department of Environment and Conservation (DEC) marine conference. Denham, Western Australia.

Nowicki, R.* "Decline, impact, and recovery of Shark Bay's seagrass community”. 25 June 2013. Department of Environment and Conservation (DEC) marine conference. Denham, Western Australia. 